Fifty Years of Soviet and Russian Drilling Activity in Polar and Non-Polar Ice

A Chronological History

Herbert T. Ueda and Pavel G. Talalay

October 2007

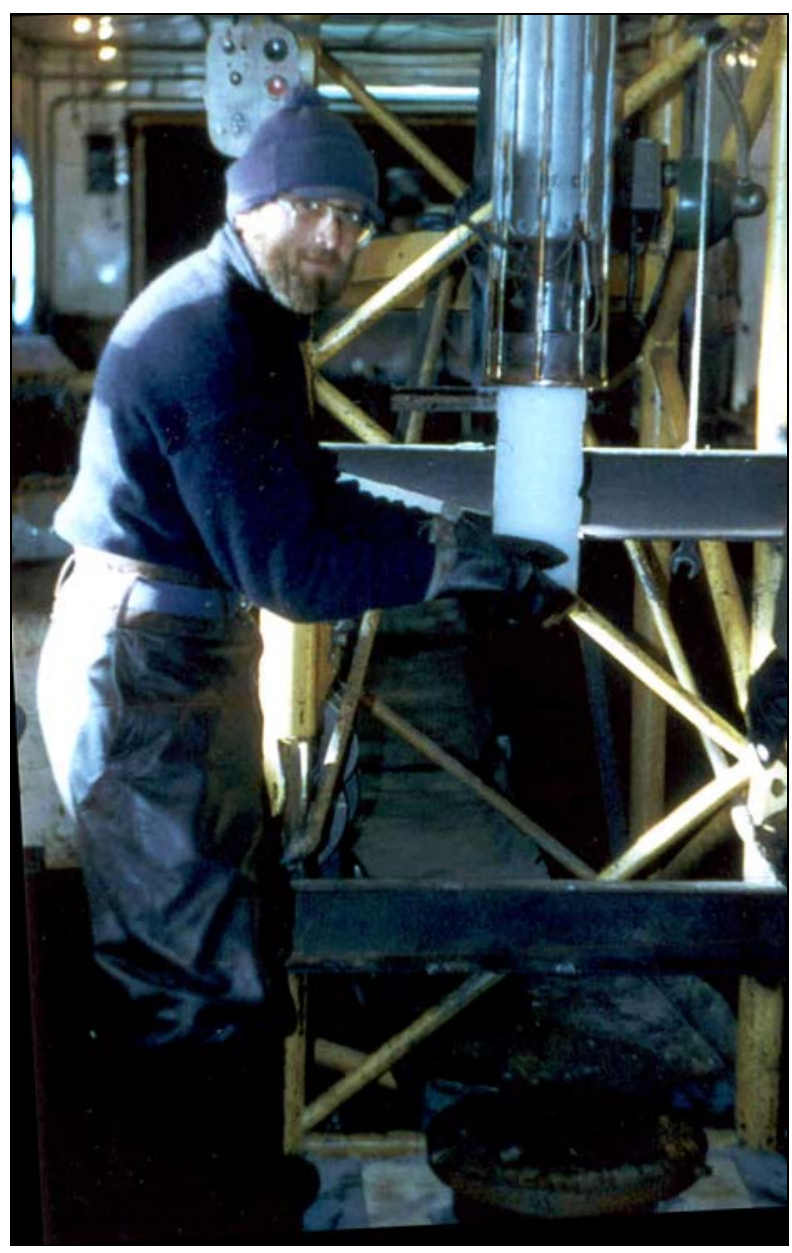


Cover: P.G. Talalay with one of the first cores recovered with the TELGA 14M thermal drill in hole (5G), Vostok Station (photo from $35^{\text {th }} \mathrm{SAE}$ ). 


\section{Fifty Years of Soviet and Russian Drilling Activity in Polar and Non-Polar Ice}

A Chronological History

Herbert T. Ueda

Cold Regions Research and Engineering Laboratory

U.S. Army Engineer Research and Development Center

72 Lyme Road

Hanover, NH 03755

Pavel G. Talalay

St. Petersburg State Mining Institute

21 Line, 2 St.-Petersburg

199026, Russia

Approved for public release; distribution is unlimited. 


\begin{abstract}
Soviet and Russian drilling activity in ice began in 1955 while conducting temperature surveys on a glacier in Franz-Josef Land in the Arctic and continued to 1960 on the glaciers of the polar Ural and the northern Tien Shen mountain ranges. In 1956 the first Complex Antarctic Expedition (CAE) was formed and the first Antarctic drilling was conducted in October of 1956 near Mirny Station. Later, the expeditions were referred to as Soviet Antarctic Expeditions (SAE) and Russian Antarctic Expeditions (RAE). Early efforts were conducted with hand drilling equipment followed by mechanical rotary and percussion drilling techniques. Thermal (flame and thermal electric) boring drills and later thermal coring drills eventually culminated in drills of the TELGA type for thermal drilling deep, dry holes. One such hole reached a depth of over $900 \mathrm{~m}$ at Vostok. Use of TBZS type thermal drills for drilling in fluid-filled holes were also developed, as was a technique using anti-freeze to dissolve the melt water formed, the dilute solution then remaining in the hole to provide the necessary hydrostatic balance. An electro-mechanical drill KEMS was first introduced on Vavilov Glacier, Severnaya Zemlya (Russian Arctic) in 1984 and then in 1989 at Vostok Station. Five major holes have been drilled at Vostok, the last one stopped in 2006 (RAE 51) at a depth of $3650 \mathrm{~m}, 100 \mathrm{~m}$ above Lake Vostok. This report chronologically summarizes the Soviet and Russian efforts over the last 50 years.
\end{abstract}

DISCLAIMER: The contents of this report are not to be used for advertising, publication, or promotional purposes. Citation of trade names does not constitute an official endorsement or approval of the use of such commercial products. All product names and trademarks cited are the property of their respective owners. The findings of this report are not to be construed as an official Department of the Army position unless so designated by other authorized documents. 


\section{Contents}

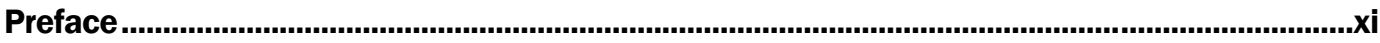

Abbreviations of Institutes............................................................................................. xii

1 Antarctica

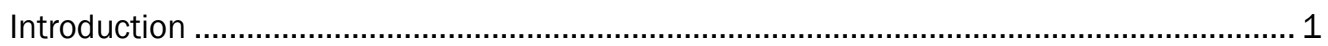

1955-56, First CAE (Complex Antarctic Expedition): Mirny................................................. 3

1956-57, Second CAE: Mirny .................................................................................... 3

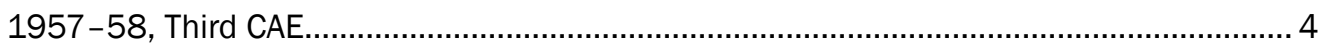

1958-59, Fourth CAE (renamed SAE, Soviet Antarctic Expedition):.................................. 4

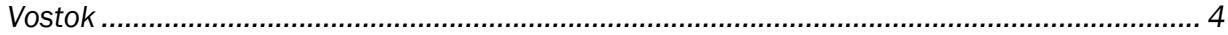

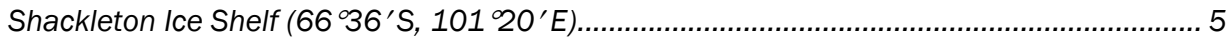

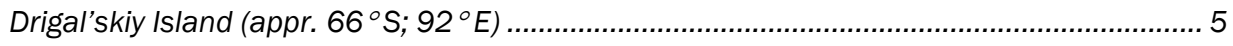

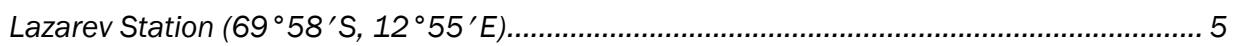

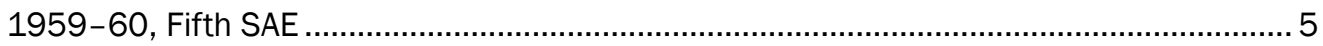

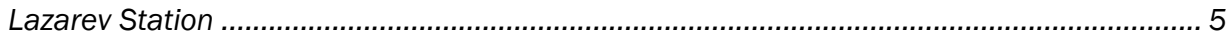

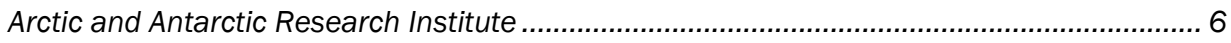

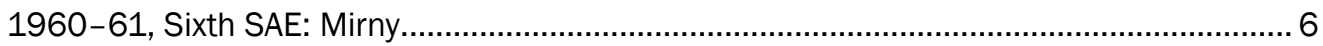

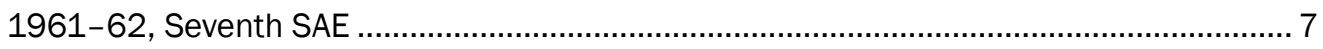

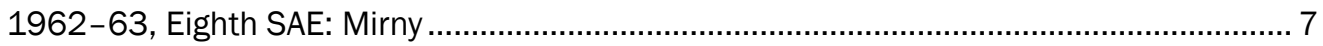

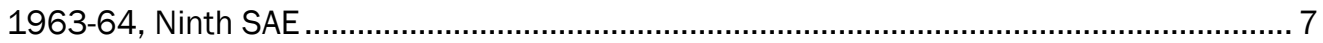

Traverse Vostok-Pole of Relative Inaccessibility $\left(78^{\circ} \mathrm{S}, 20^{\circ} \mathrm{E}\right)$-Molodyezhnaya................ 7

$1964-65$, Tenth SAE ................................................................................................. 7

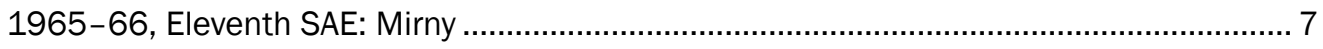

1966-67, Twelfth SAE: Novolazarev Ice Shelf ............................................................. 8

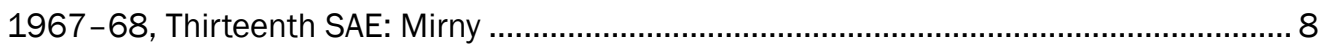

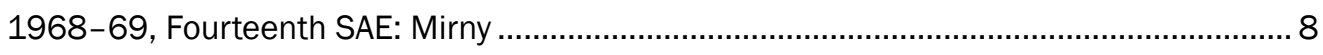

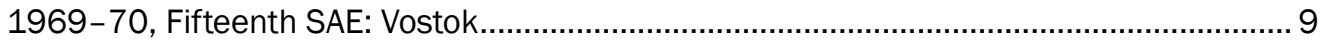

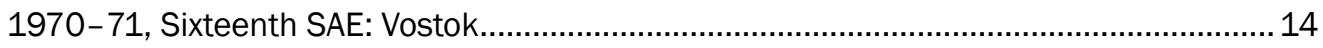

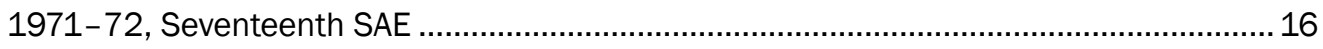

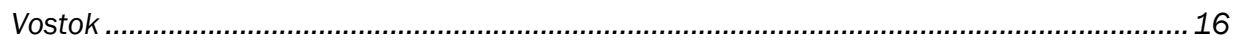

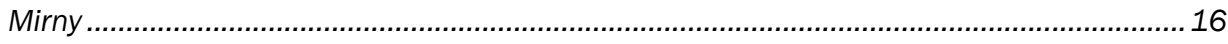

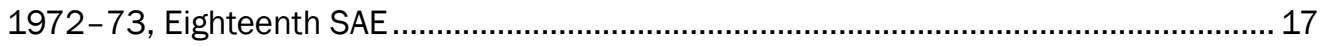

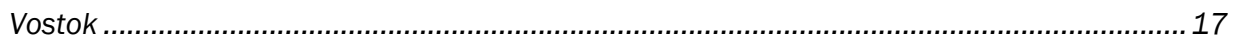

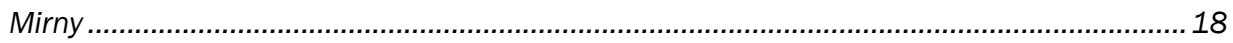

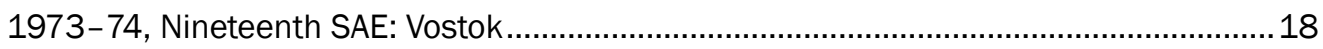

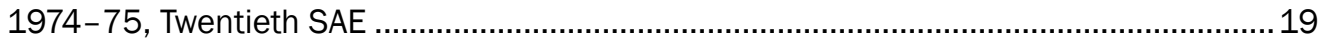

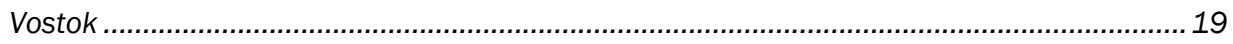

Vostok-1 (72 $08^{\prime}$ S, $96^{\circ} 3^{\prime}$ E, 647 km mark on the Mirny-Vostok route)............................ 20

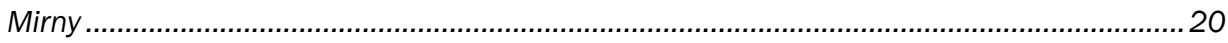

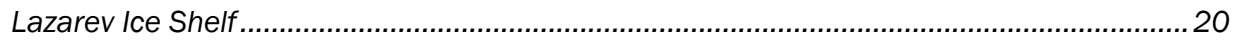




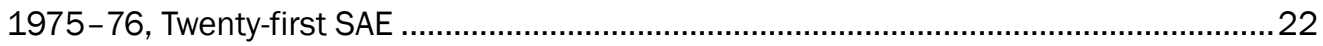

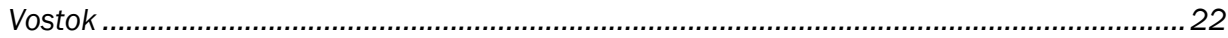

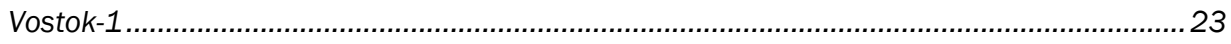

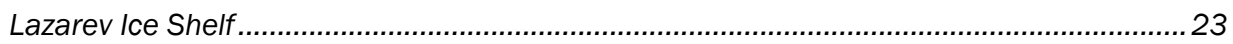

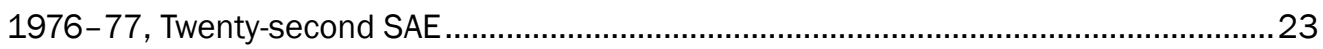

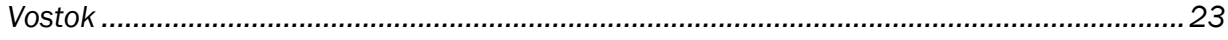

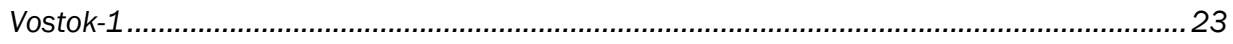

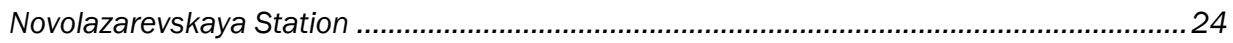

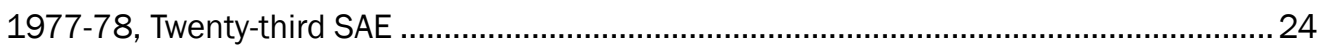

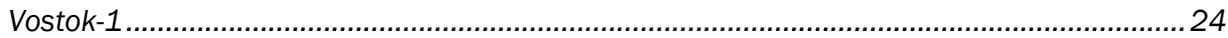

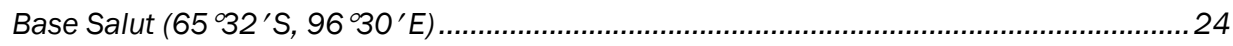

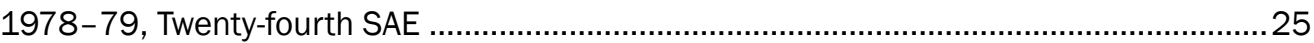

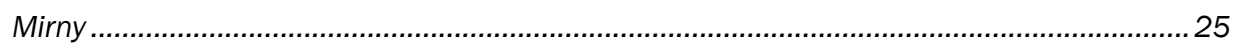

Pionerskaya (69 $44^{\prime}$ 'S, $95^{\circ} 30^{\prime}$ E, 375-km mark on the Mirny-Vostok route)....................... 25

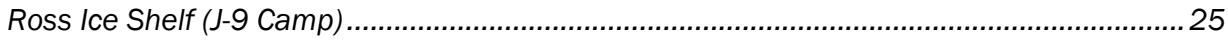

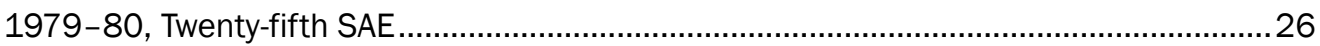

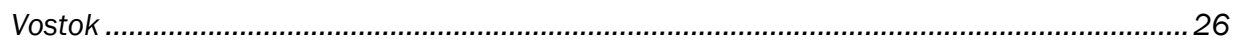

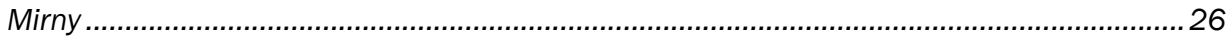

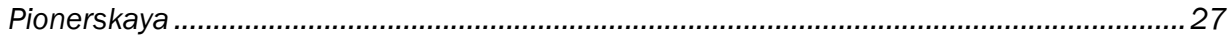

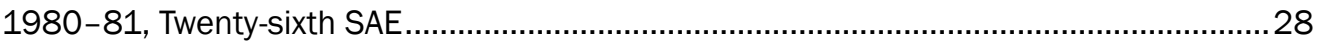

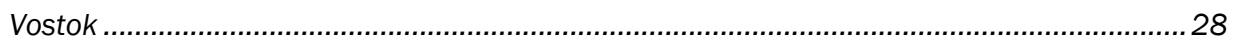

Komsomolskaya Station (74 O6'S; 94 30'E, 870 km south of Mirny)................................29

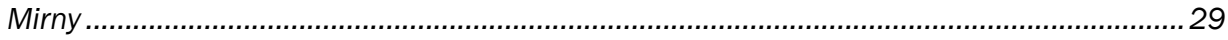

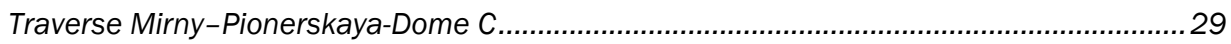

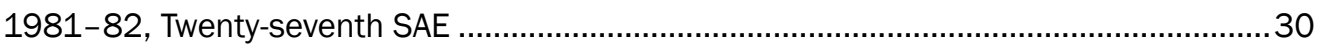

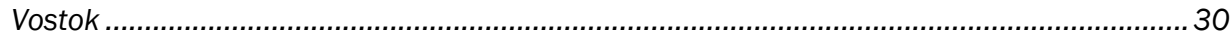

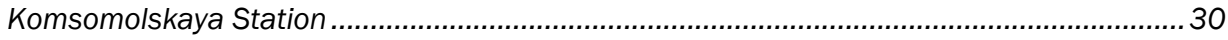

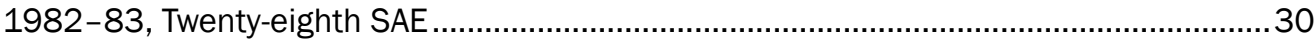

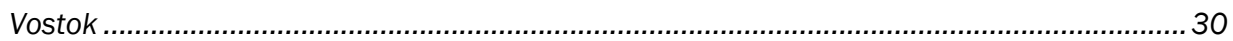

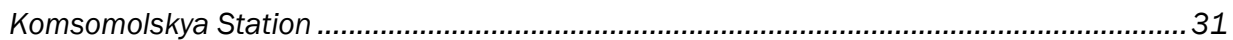

Base Druzhnaya (77 O34'S; 40 `13'W, Filchner Ice Shelf)................................................... 32

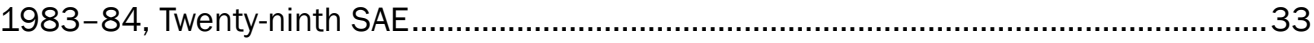

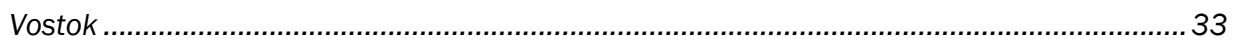

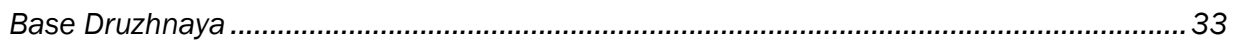

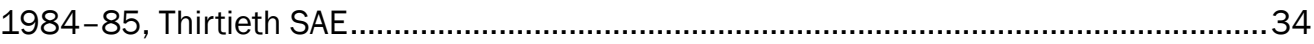

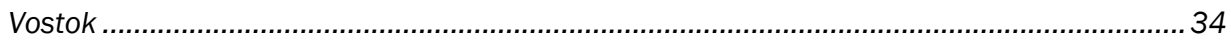

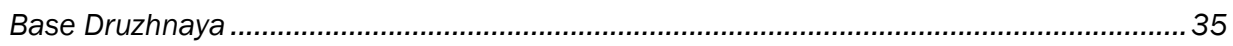

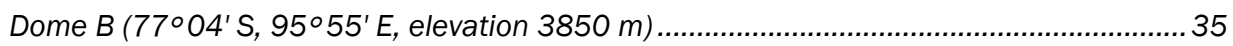

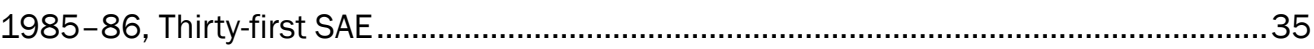

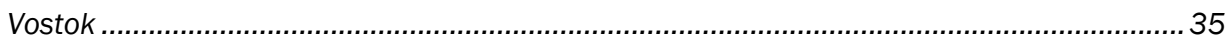

Dome $B$.

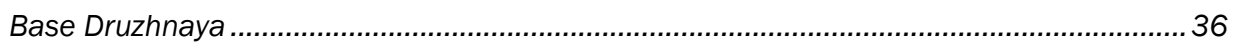

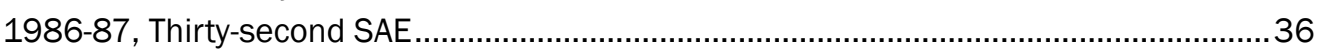

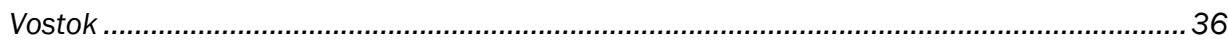

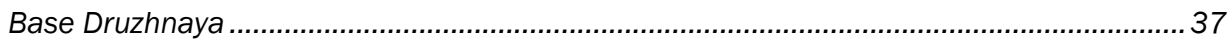




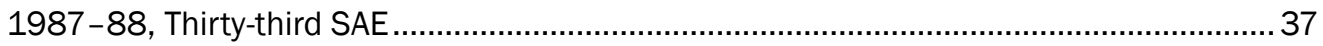

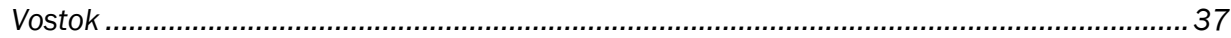

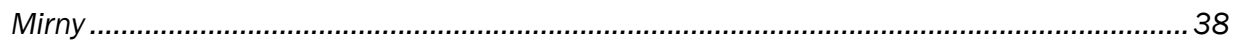

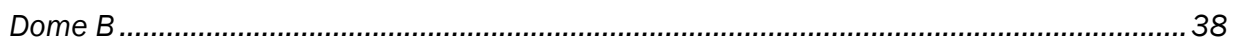

Base Druzhnaya-4 (69 ^44'S; 72 $42^{\prime}$ 'E; Oasis near Emery Ice Shelf)................................. 38

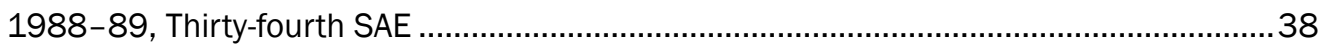

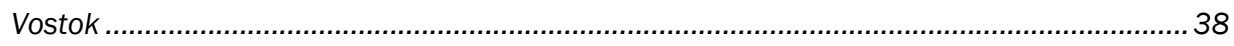

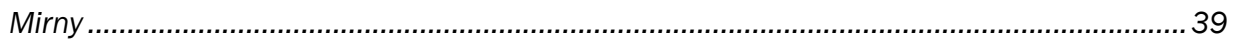

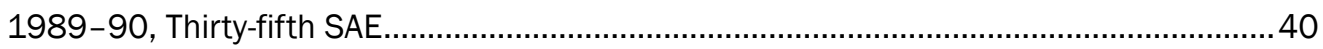

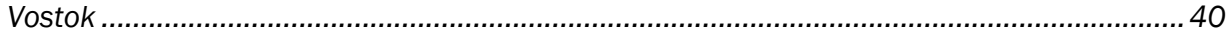

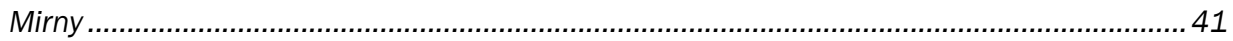

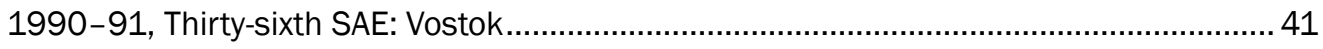

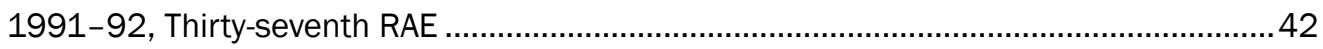

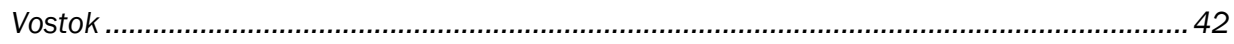

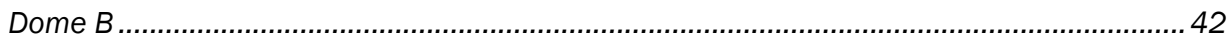

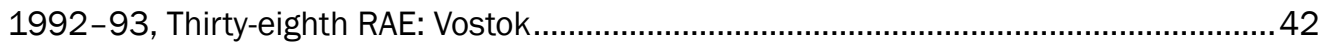

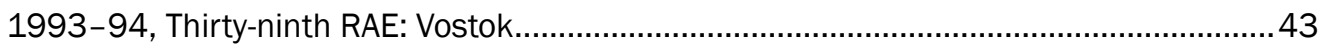

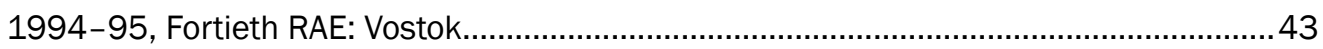

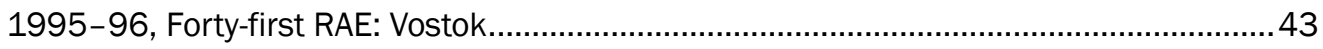

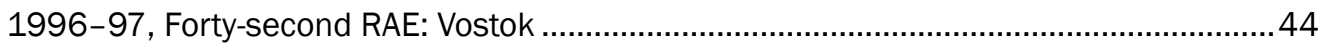

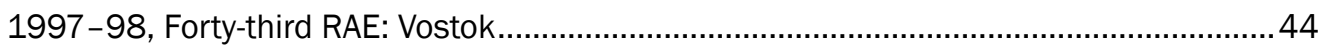

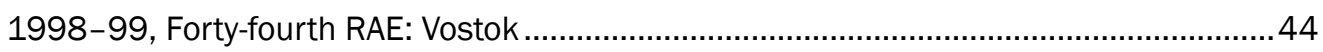

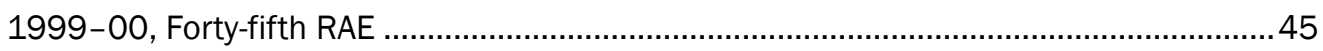

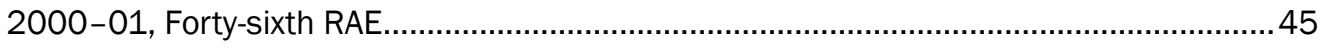

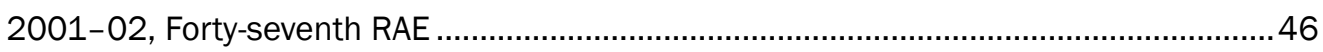

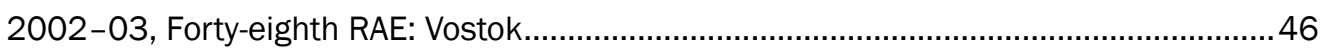

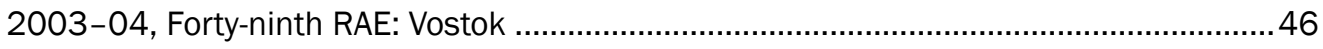

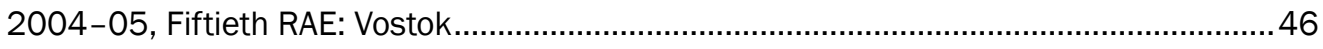

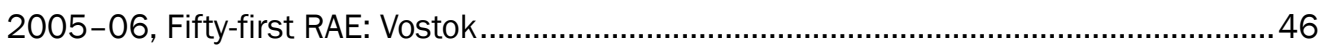

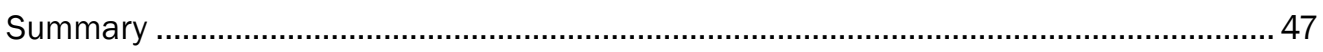

2 Soviet and Russian Drilling Activity in the Arctic and Non-Polar Regions..........................49

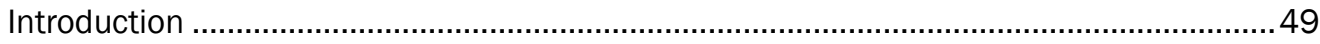

1955-1960: Franz-Josef Land, Novaya Zemlya, Polar Urals, Tien Shan ............................58

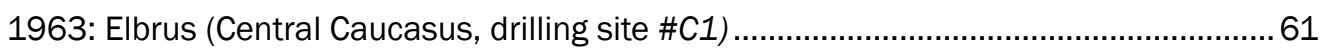

1964: Tuiuksu Glacier (Zailiiskii Alatau, Northern Tien Shan, drilling site \#CA1) ..............63

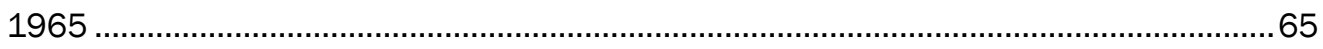

Noredenskiöld Glacier (Spitsbergen) .........................................................................6

Karabatkak Glacier (Terskei Alatau, Internal Tien Shan, drilling site \#CA2) ........................65

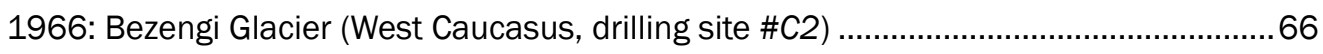

1967: Marukh Glacier (West Caucasus, drilling site \#C3)) .................................................6

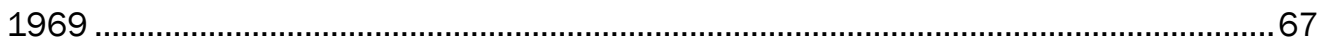

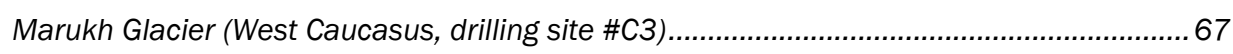

Tuiuksu Glacier (Zailiiskii Alatau, Northern Tien Shan, drilling site \#CA1) ........................... 67

1970, 1971: Jankuat Glacier (Central Caucasus, drilling site \#C4 ) ..................................68

1971: Abramov Glacier (Alai Ridge, Pamirs, drilling site \#CA3).......................................69 
Abramov Glacier (Alai Ridge, Pamirs, drilling site \#CA3) ....................................................70

Jankuat Glacier (Central Caucasus, drilling site \#C4 ).........................................................70

Drifting station Severnyi Polyus-19 (ice island in the Arctic Ocean) ...................................... 70

1973

71

Abramov Glacier (Alai Ridge, Pamirs, drilling site \#CA3) .............................................. 71

Jankuat Glacier (Central Caucasus, drilling site \#C4 ) ........................................................... 71

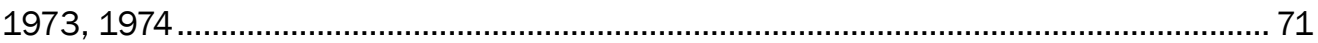

Obruchev Glacier (Polar Urals) .................................................................................... 71

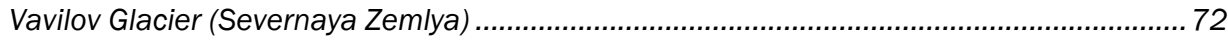

Abramov Glacier (Alai Ridge, Pamirs, drilling site \#CA3) .................................................... 73

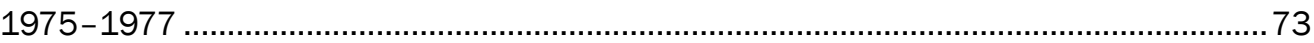

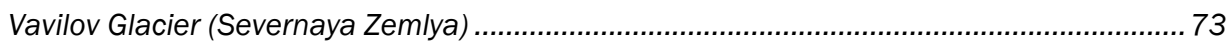

Ice-divide area between East Grënfjord and Fridtjof glaciers (Spitsbergen, drilling

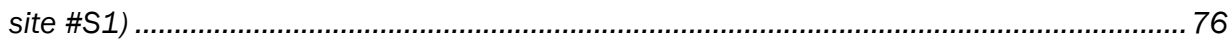

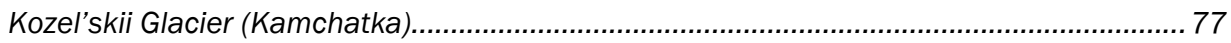

Lomonosov Plateau (Spitsbergen, drilling site \#S3) ......................................................... 77

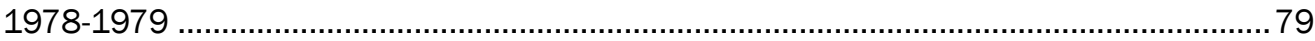

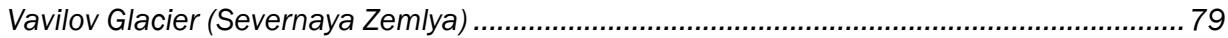

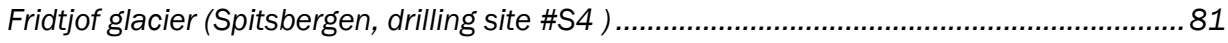

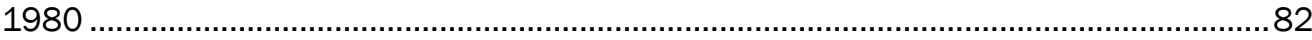

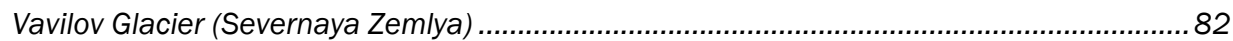

Bertil Glacier (drilling site \#S5), Bogger Glacier (drilling site \#S6), and Amundsen

Plateau (drilling site \#S7), Spitsbergen ...................................................................... 82

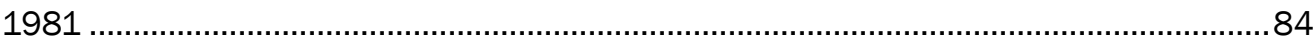

Vestfonna (Nordaustlandet, Spitsbergen, drilling site \#S8) ............................................... 84

Vavilov Glacier (Severnaya Zemlya) ................................................................................ 84

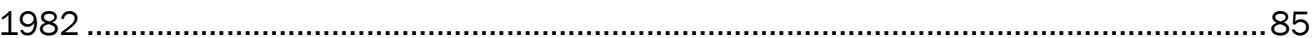

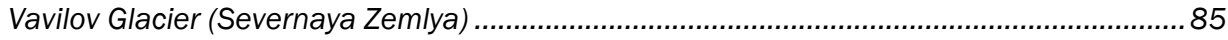

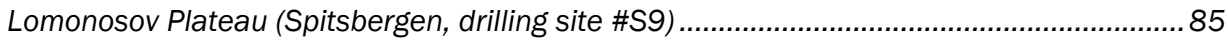

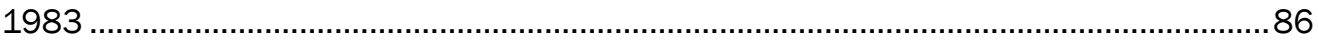

Vavilov Glacier (Severnaya Zemlya) ............................................................................. 86

Dzhantuganskoye Firn Plateau (Central Caucasus, drilling site \#C5).................................. 86

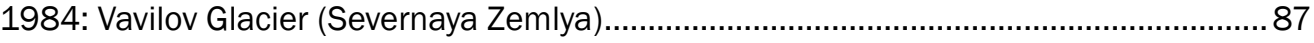

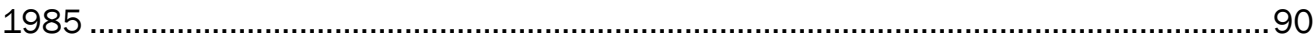

Vavilov Glacier (Severnaya Zemlya) ................................................................................90

Austfonna (Nordaustlandet, Spitsbergen, drilling site \#S10)............................................. 90

Davydov Glacier (Akshirak, Internal Tien Shan, drilling site \#CA4 ) .....................................91

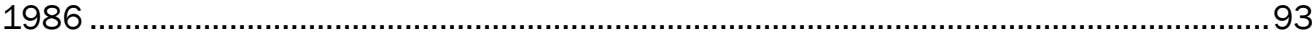

Vavilov Glacier (Severnaya Zemlya) ..................................................................................... 93

Akademiya Nauk Glacier (80 $30^{\prime} \mathrm{N}$ and $94^{\circ 5}$ ' $\mathrm{E}$, Severnaya Zemlya, drilling site

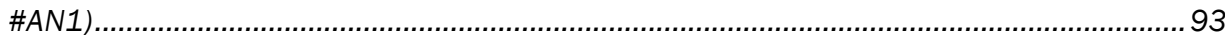


1987

Vavilov Glacier (Severnaya Zemlya)

Akademiya Nauk Glacier (80 $30^{\prime}$ N and 94 $50^{\prime}$ 'E, Severnaya Zemlya, drilling site \#AN1).

Austfonna (Nordaustlandet, Spitsbergen, drilling site \#S11).............................................. 95

Garabashi Glacier (Elbrus, Central Caucasus, drilling site \#C6) ..........................................96

1988.

Vavilov Glacier (Severnaya Zemlya)

Garabashi Glacier (Elbrus, Central Caucasus, drilling site \#C6) .........................................97

1989-1990: South Inylchek Glacier (Central Tien Shan, drilling site \#CA5) ......................98

1990

Grigor'ev Glacier (Terskei Alatau, Internal Tien Shan, drilling site \#CA6).............................99

Bolshoi Azau Glacier (Elbrus, Central Caucuses, drilling site \#C7) ........................................ 99

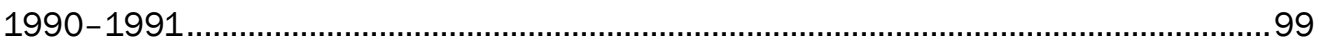

Loonyi Glacier (Zemlya Aleksandry Island, Franz Josef Land).............................................99

South-eastern Tibet and Northern Slope of Himalayas ....................................................100

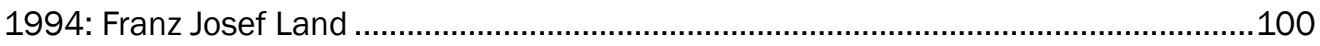

1996: Gorshkov Glacier (Ushkovskii Volcano, Kamchatka)........................................100

1997: Windy Glacier (Graham Bell Island, Vetrennyi Ice Cap, Franz Josef Land) .............101

1998: Gorshkov Glacier (Ushkovskii Volcano, 3901 m a.s.I., Kamchatka) .....................102

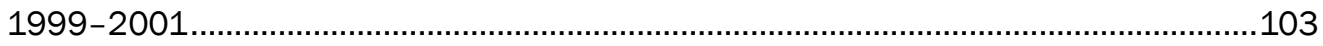

Akademiya Nauk Glacier $\left(80.52^{\circ} \mathrm{N}\right.$ and $94.8^{\circ} \mathrm{E}$, Severnaya Zemlya, drilling site

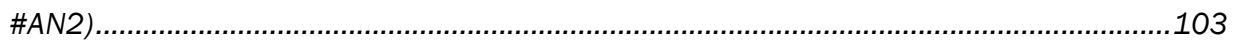

Rvanniy Glacier, South Inylchek (Central Tien Shan)......................................................105

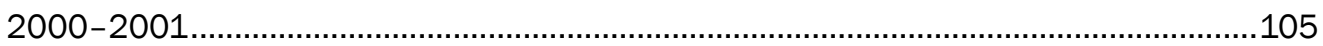

Eastern Plateau of Mt. Belukha (Altai Mountains) .............................................................105

Sofiyskiy Glacier, Altai Mountains (4947' 10" N, 8743' 43" E, 3450 m a.s.I.).................106

2003: Western Plateau of Mt. Belukha (Altai Mountains) ..............................................106

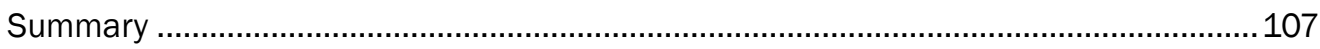

References..................................................................................................................................... 109

Report Documentation Page....................................................................................................... 131 


\section{Figures and Tables}

\section{Figures}

Figure 1. Main locations of Soviet and Russian drilling activity in Antarctica................................2

Figure 2. First experience of thermal drilling at Vostok Station during the $4^{\text {th }}$ CAE. ................... 4

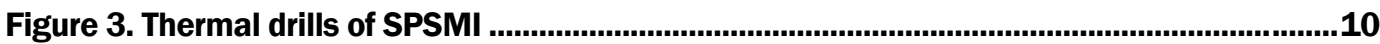

Figure 4. Schematic diagram of the electro-thermal drilling equipment at Vostok Station

Figure 5. Schematic of deep holes at Vostok Station drilled by SPSMI.

Figure 6. Drill building at Vostok station in the summer season of the $17^{\text {th }} \mathrm{SAE}$ 15

Figure 7. Microbiological drilling building at Vostok Station. 19

Figure 8. a-ETB-1 electro-thermal core drill. b-ETB-3 electro-thermal core drill. 21

Figure 9. Schematic diagram of the ETB-5 electro-thermal core drill.....................................27

Figure 10. Schematic of drilling complex at base Pobeda .............................................................28

Figure 11. Drilling complex at Vostok Station used for drilling of $4 G$ and $5 G$ holes .................31

Figure 12. Drilling shelter at Druzhnaya .......................................................................................32

Figure 13. Core auger used at Druznaya Station for drilling in firn. .........................................34

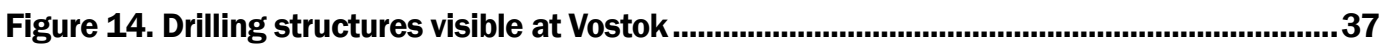

Figure 15. KEMS-132 electro-mechanical drill....................................................................40

Figure 16. Drilling shelter above hole (5G) constructed during the 27th and 28th SAE.............41

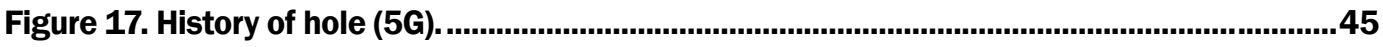

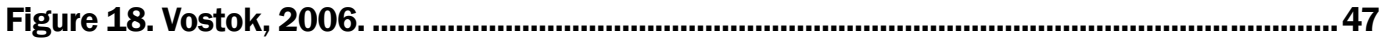

Figure 19. Core barrel of Tsykin's hand ice drill.............................................................59

Figure 20. Drilling operations on Churlyenis Glacier, Franz Josef Land, 1958-1959.................61

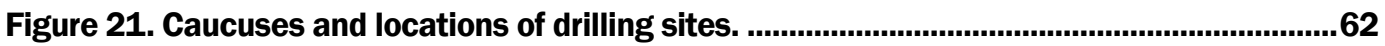

Figure 22. Drive tube of the cable-percussion drilling rig......................................................63 
Figure 23. Central Asia and location of drilling sites. ........................................................64

Figure 24. Jet-fire drill ...................................................................................................................64

Figure 25. Jet-fire drilling on Tuiuksu Glacier, Northern Tien Shan...............................................68

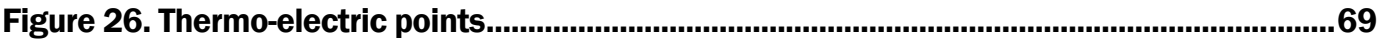

Figure 27. Device for recording penetration rate..........................................................................72

Figure 28. Severnaya Zemlya archipelago, showing location of glaciological station Kupol Vavilova and drilling sites ....................................................................................... 74

Figure 29. Spitsbergen archipelago and locations of drilling sites.........................................78

Figure 30. Lightweight thermal drilling rig of LMI: ....................................................................87

Figure 31. KEMS-112 electro-mechanical core drill .......................................................................89

Figure 32. Drilling complex on Austfonna, Spitsbergen ..............................................................92

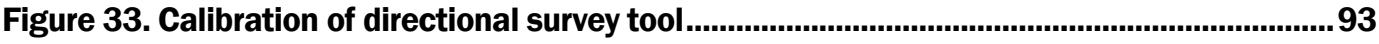

Figure 34. Drilling shelter construction at glaciological station Kupol Vavilova, Severnaya Zemlya ..........................................................................................................95

Figure 35. Plan of drilling shelter at glaciological station Kupol Vavilova, Severnaya Zemlya

Figure 36. Sub-glacial core from 461.6-m-deep hole at Kupol Vavilova, Severnaya Zemlya 98

Figure 37. Drill m-ATED 102

Figure 38. Drilling shelter on Akademiya Nauk Glacier, Severnaya Zemlya:.......................... 104

Figure 39. Drilling shelter on Akademiya Nauk Glacier, Severnaya Zemlya............................. 105

\section{Tables}

Table 1. Main characteristics of thermal drills. ...................................................................... 9

Table 2 Deep Drilling At Vostok Station. ...............................................................................11

Table 3. LMI drilling on the Mirny-Vostok Route. ........................................................................16

Table 4. AARI and IGRAS drilling with anti-freeze thermal electric drills....................................22

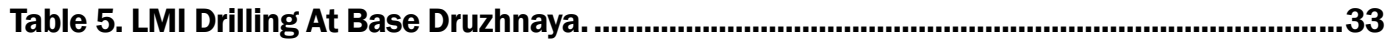

Table 6. Main characteristics of electro-mechanical drills......................................................39

Table 7. Soviet Drilling activity In the Arctic and non-polar regions. ............................................50 


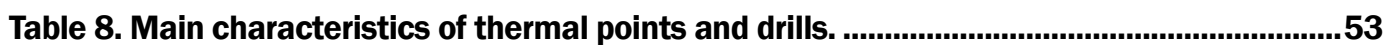

Table 9. AARI, IGAS and LMI (SPSMI) drilling on Severnaya Zemlya.......................................54

Table 10. IGAS thermal drilling on Spitsbergen. .................................................................57 


\section{Preface}

This report was prepared by Herbert T. Ueda (USACRREL retired) and Pavel G. Talalay of the St. Petersburg State Mining Institute, Russia. The report is dedicated to those hardy souls of the various Soviet and Russian Polar Expeditions who tirelessly spent so many years and expended so much effort to further the cause of glaciology. From the first drilling attempts in 1955, to the termination of the last hole above Lake Vostok by the 51st Russian Antarctic Expedition, their accomplishments have been substantial.

The authors thank Assoc. Prof. N. Vassiliev (Department of Drilling Technique and Technology, St. Petersburg State Mining Institute, Russia), Prof. V. Aizen (Department of Geography, College of Science, University of Idaho, USA), and Managing Director A. Takahashi (Geo Tecs Co., Japan) for their critical remarks and fruitful discussion, as well as E. Talalay for help in preparing the figures, and D. Garfield (USACRREL retired) and F. Wilhelms (Alfred-Wegener Institut fuer Polar und Meeresforschung) for reviewing the paper.

This report was prepared under the general supervision of Thomas Tantillo, Chief, Engineering Resources Branch; Dr. Lance Hansen, Acting Deputy Director; and Dr. Robert Davis, Director, CRREL. The Commander and Executive Director of the Engineer Research and Development Center is COL Richard B. Jenkins. The Director is Dr. James R. Houston. 


\section{Abbreviations of Institutes}

AARI-Arctic and Antarctic Research Institute

IGAS, IGRAS,-Institute of Geography USSR Academy of Sciences or Institute of Geography Russian Academy of Science

LMI, SPSMI-Leningrad Mining Institute or since 1991 St. Petersburg State Mining Institute

MIRGEM-Moscow Institute of Radioelectronics and Mining Electromechanics

MMI-Moscow Mining Institute

SARNIGMI-Middle-East Regional Research Hydro-Meteorological Institute, Tashkent 


\section{Antarctica}

\section{Introduction}

Modern Soviet involvement in the Antarctic began in 1955-56 shortly before the International Geophysical Year. On 13 November 1955, the Ob', the first of two ships left Russia, followed on 14 December 1955 by the Lena. The Ob' reached Antarctica on 5 January 1956 via the Davis Sea and by 15 January 1956 arrived at the present site of Mirny $\left(66^{\circ} 33^{\prime} \mathrm{S}, 93^{\circ} \mathrm{O} 1^{\prime}\right.$ E), which was opened on 13 February 1956 (Korotkevich 1966). On 18 November 1955, the first program of the Complex Antarctic Expedition (CAE) was approved by the Presidium of Academy of Sciences of the USSR. In 1959 CAE was renamed Soviet Antarctic Expedition (SAE), and since 7 August 1992, according to Edict № 824 of the President of the Russian Federation, SAE became Russian Antarctic Expedition (RAE).

The first drilling occurred during the first (CAE) in October of 1956. Since then, drilling and coring of some kind has taken place almost annually, except for the years 1999-2005. Early efforts were concentrated on developing thermal devices that drilled dry holes and reached significant depths. Next, thermal drills for use in fluid-filled holes were developed.

During the 1970s the design of thermal drilling equipment became somewhat of a competition between a group led by V.A. Morev from the Arctic and Antarctic Research Institute (AARI) and a group led by B.B. Kudryashov from the Leningrad Mining Institute (LMI, since 1991 St Petersburg State Mining Institute-SPSMI). The work of both groups had their successes and problems, some of which were carefully hidden and sometimes the reasons for accidents were not published. This report has tried to obtain data from available publications and in some instances from personal communications with some of the people who were involved in the drilling projects.

The technology of Morev's thermal drills was based on the use of ethanol to dissolve the melted ice. The melt water-ethanol solution is then left down hole, where it provides the necessary hydrostatic pressure compensation. Ethanol has a low toxicity, a relatively low cost, a low environmental hazard potential, and other desirable characteristics. However, these characteristics are negated by the fact that the solution, under cer- 
tain temperature conditions, also dissolves ice from the borehole wall, resulting in the formation of slush.

For drilling deep holes in cold (less than $-30^{\circ} \mathrm{C}$ ) ice, and assuming that the borehole may be required to stay accessible for many years, experience has shown that only the use of hydrophobic fluids are suitable. Such drilling fluids were investigated and introduced by the technology of Kudryashov's group (Talalay and Gundestrup 2002). In the mid 1980s, electromechanical drills for use in fluid-filled holes were developed by the SPSMI, which succeeded in reaching record depths of $3000 \mathrm{~m}$ or more.

The main locations of Soviet and Russian drilling activity in the Antarctic are shown in Figure 1. This report is a chronological history of the past 50 years of Soviet and Russian drilling activity in the Antarctic.

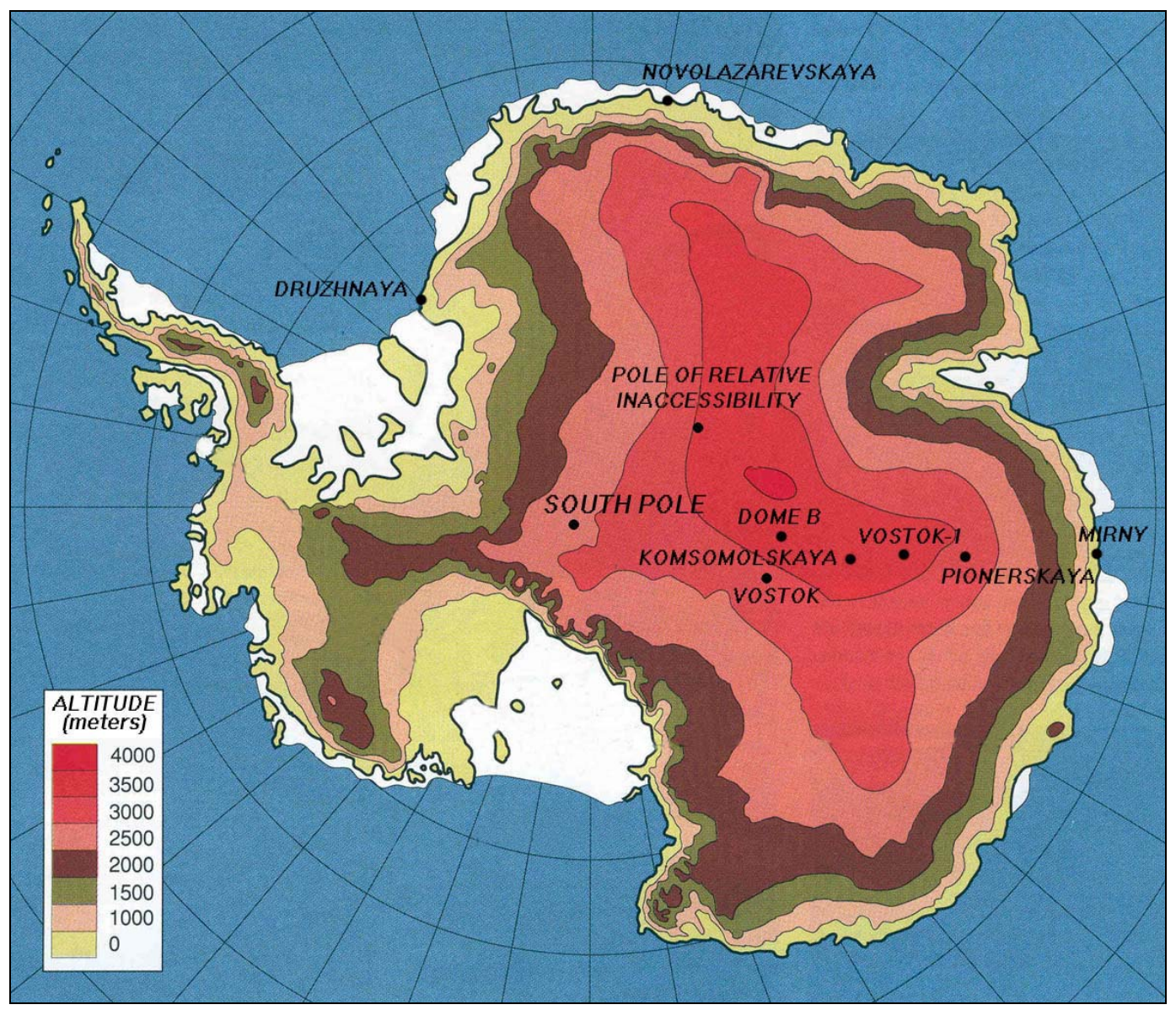

Figure 1. Main locations of Soviet and Russian drilling activity in Antarctica. 


\section{5-56, First CAE (Complex Antarctic Expedition): Mirny}

The first drilling experience in Antarctica was carried out in October of 1956 just outside Mirny (Kapitsa 1958; Model 1959). Two holes to depths of 23.5 and $86.5 \mathrm{~m}$ were drilled using a conventional GP-1 type drilling rig. The outer diameter of the drill head was $60 \mathrm{~mm}$, no cores were retrieved, and the penetration rate was $9.5 \mathrm{~m} / \mathrm{h}$. The cuttings were removed by the circulation of air provided by a PKS- 6 portable air compressor.

\section{6-57, Second CAE: Mirny}

During this expedition two drilling projects were conducted. The first project was carried out by a conventional, KAM-500 mechanical drilling rig without any special devices for lifting the cuttings (Treshnikov 1960; Shumskyi 1960). It is not clear how the cuttings were removed. Several (16) types of cutting bits were used, along with several core barrels and various rotational speeds but nothing resulted in improved cores. The cores were broken up into pieces $5^{-15} \mathrm{~cm}$ in length. The first $20-30 \mathrm{~cm}$ of penetration on each run went well but excessive cutter loading was required thereafter. It was possible to obtain a 0.8-1.2 $\mathrm{m}$ drill run. Three holes were drilled:

- $66.7 \mathrm{~m}$ deep at Mirny (7 July-10 September 1957): the hole penetrated $2.2 \mathrm{~m}$ into sub-glacial rock using shot drilling. This was a technique used in hard material prior to diamond bit drilling in which steel or cast iron pellets are fed beneath a rotating bit. During rotation the pellets break into small, sharp pieces, which erode the rock.

- $371 \mathrm{~m}$ deep, $7 \mathrm{~km}$ south of Mirny (September-24 December 1957): at a depth of $220 \mathrm{~m}$, fluid circulation using kerosene was tested but the experiment failed. After pumping out the kerosene, dry hole drilling was continued.

- $100 \mathrm{~m}$ deep, $45 \mathrm{~km}$ south of Mirny (17-21 January 1958).

The second project was conducted within a 225-km radius of Mirny using a conventional UShB-1 auger rig (Treshnikov 1960; Kartashov 1960). From February 1957 to January1958, 98 holes with a total length of 1632 $\mathrm{m}$ without core were drilled. The deepest was $102 \mathrm{~m}, 50 \mathrm{~km}$ from Mirny. 


\section{7-58, Third CAE}

Vostok Station was established on 16 December $1957,1410 \mathrm{~km}$ south of Mirny at the South Geomagnetic Pole $\left(78^{\circ} 28^{\prime} \mathrm{S}, 106^{\circ} 48^{\prime} \mathrm{E}\right)$, at an elevation of 3488 m (Aver'yanov 1968).

\section{8-59, Fourth CAE (renamed SAE, Soviet Antarctic Expedition):}

Vostok

AARI (Arctic and Antarctic Research Institute) drilled four boreholes with a hot point thermal drill to a maximum depth of $52 \mathrm{~m}$ (Figure 2). Nine thermal drill types were tested. One device built by D.A. Nizaev allowed the study of the rate of penetration of a thermal drill with depth to solid ice through the various densities of the firn (Ignatov 1960a,b; Ignatov 1962). The penetration rate decreased from $1.3-1.6 \mathrm{~m} / \mathrm{h}$ in snow to $0.25 \mathrm{~m} / \mathrm{h}$ in ice.

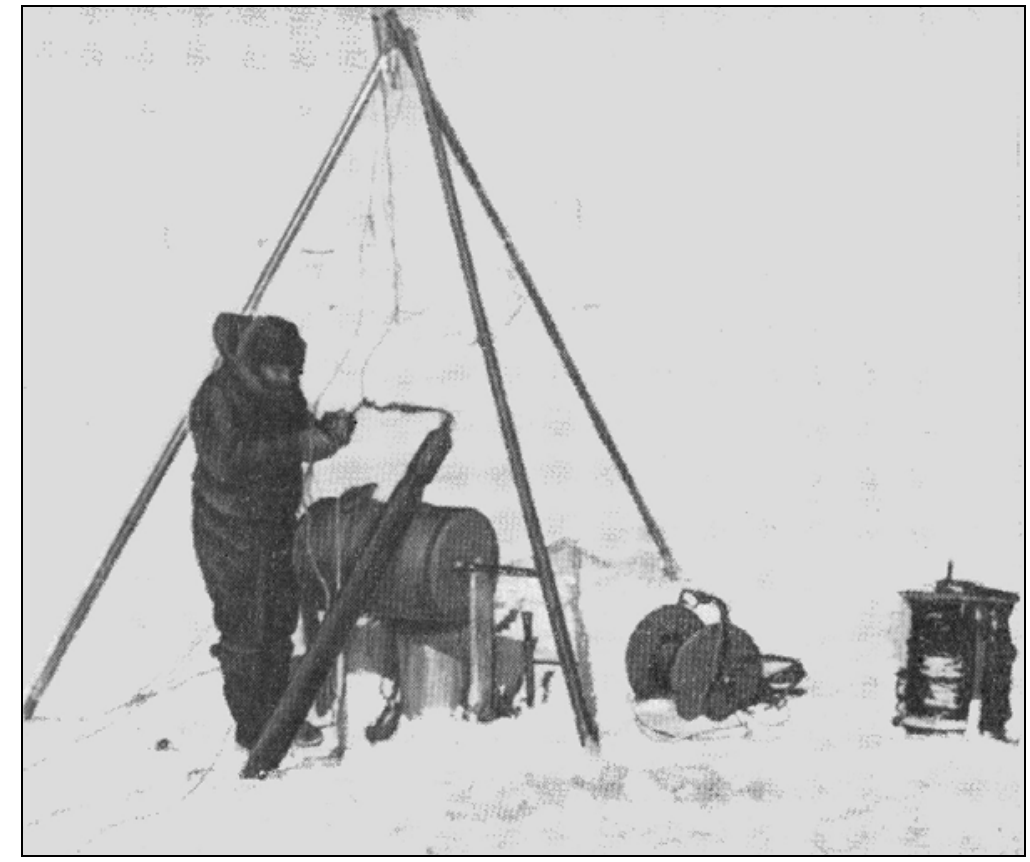

Figure 2. First experience of thermal drilling at Vostok Station during the $4^{\text {th }}$ CAE (from Ignatov 1962).

\section{Mirny}

A drilling project was conducted in conjunction with seismic investigations. The type URB-1 auger rig, weighing $485 \mathrm{~kg}$, was specially built by Gyproneftemash and mounted on a sled with a shelter. Near Mirny station, several holes with depths from 30 to $70 \mathrm{~m}$ were drilled with a total 
length of $380 \mathrm{~m}$. The drill was rotated at $75-85 \mathrm{rpm}$ and the hole diameters were $120 \mathrm{~mm}$. The rate of penetration decreased with depth from 180 (sic) to $3.6 \mathrm{~m} / \mathrm{h}$ (Dralkin 1963; Korotkevich 1965). Zotikov (1979) discussed additional experiments with a thermal drill at Mirny and Komsomolskaya Stations, but there were no further detailed publications of this drilling.

\section{Shackleton Ice Shelf $\left(66^{\circ} 36^{\prime} \mathrm{S}, 1^{101^{\circ}} 20^{\prime} \mathrm{E}\right)$}

Drilling was conducted down to $32 \mathrm{~m}$ (Dralkin 1963). The type of drill was not reported.

\section{Drigal'skiy Island (appr. $\left.66^{\circ} \mathrm{S} ; 9^{\circ} \mathrm{E}\right)$}

Thermal drilling to a depth of $44 \mathrm{~m}$ was conducted by A.P. Kapista and A.V. Krasnushkin in the central part of Drigal'skiy Island. The drill was essentially a cable-suspended electric hot point used successfully in firn (Korotkevich 1965; Zotikov et al. 1974).

\section{Lazarev Station $\left(69^{\circ} 58^{\prime} \mathrm{S}, 1^{\circ} 55^{\prime} \mathrm{E}\right)$}

Yu.A. Kruchinin drilled two holes using a thermal drill with a 60-mmdiameter head. The first hole was drilled to a depth of $27 \mathrm{~m}$ in May 1959 and the second hole to a depth of $37 \mathrm{~m}$ in August 1959. During drilling of the second hole, salt water appeared in the hole, resulting in a short circuit within the electrical system of the drill (Dubrovin 1960; Kruchinin 1965).

\section{9-60, Fifth SAE}

\section{Lazarev Station}

L.A. Dubrovin used a thermal drill similar to one used in SAE-4 to an unknown depth. (Zotikov et al. 1974).

A.I. Morozov, a mechanic at Lazarev Station, manufactured two types of thermal drills. The first one was made from a 110-mm-diameter container with two thermal heaters (the power of each heater was $0.5 \mathrm{~kW}$ ), with electric contacts hermetically sealed. During March-June 1960, with this simple device, four holes with depths from 42 to $44 \mathrm{~m}$ were drilled, with a mean penetration rate of $0.43-0.58 \mathrm{~m} / \mathrm{h}$. The melt water was removed in a special container (Dubrovin 1960; Korotkevich 1965). 
The second thermal drill was made from a steel fuel drum. The diameter of the thermal drill was $700 \mathrm{~mm}$, and the total power of the heaters was 1.8 $\mathrm{kW}$. The drill was used for deepening of a 9-m hole down to $36 \mathrm{~m}$. The uninterrupted drilling of this hole took almost one month (30 July-28 August 1960), with a mean penetration rate of $0.05 \mathrm{~m} / \mathrm{h}$ (Korotkevich 1965). Lazarev Station operated from 10 March 1959 to 26 February 1961 and was closed because of the danger of the ice shelf breaking up (Savatyugin and Preobrazhenskaya 1999).

\section{Arctic and Antarctic Research Institute}

N.I. Barkov of AARI proposed developing a cable-suspended, electricpowered thermal drill with an annular heating head capable of producing a core and having a pumping system to remove the melt water and store it in a chamber within the drill (Barkov 1963).

\section{0-61, Sixth SAE: Mirny}

V.A. Morev tested the main principles of thermal drilling during AugustNovember 1961 (Barkov 1963). Three types of heating heads were tested. They included a conical, an end-plate, and an annular heating element.

The conical heater, intended for drilling a borehole with no core, was a copper vessel with a spherical point containing six tubular electric heaters imbedded in lead with a total rating of $6 \mathrm{~kW}$. A penetration rate of 1.03 $\mathrm{m} / \mathrm{hr}$ was achieved in a dry hole. When an asymmetric connection of the heating elements was tried, it was noted that the hole deflected in the direction of the more intensely heated side of the hot point.

The end-plate heater, also intended for drilling a hole with no core, consisted of two $3-\mathrm{kW}$ tubular heaters coiled into a spiral and embedded in lead in a steel cylinder. The tubular heaters protruded a third of their diameter. A penetration rate of $3.6 \mathrm{~m} / \mathrm{h}$ was achieved in a dry hole.

The annular heater intended for drilling a borehole and retrieving a core consisted of two turns of a single 3 -kW tubular electric heater. The drill was tested in a dry and a diesel-fuel-filled hole. The drill produced a $15 \mathrm{~cm}$ diameter hole and a 7.5-cm diameter core at a penetration rate of $7.5 \mathrm{~m} / \mathrm{h}$ in the dry hole and a $15-\mathrm{cm}$ diameter hole with a $7-\mathrm{cm}$ diameter core at a penetration rate of $7.0 \mathrm{~m} / \mathrm{h}$ in the fluid-filled hole (Morev 1966). 


\section{1-62, Seventh SAE}

Vostok Station was closed from January 1962 to January 1963 under orders from the headquarters of the Main Administration of the Northern Sea Route (Aver'yanov 1968).

\section{2-63, Eighth SAE: Mirny}

A prototype thermal device, similar to one proposed by N.I. Barkov, produced a 25-m-deep bore hole without core in solid ice in early December 1963. It consisted of an end plate heater, a BTsN-1 pump, and a 22-L water collection tank. The power consumed by the drill was $4.5 \mathrm{~kW}$. The diameter of the hole was $150 \mathrm{~mm}$, the rate of penetration $2.2 \mathrm{~m} / \mathrm{h}$; and the length of a run $1.3 \mathrm{~m}$. Drilling was discontinued because of a breakdown of the hydraulic winch. (Morev 1966).

\section{3-64, Ninth SAE}

Development work started by MMI (Moscow Mining Institute) and MIRGEM (Moscow Institute of Radioelectronics and Mining Electromechanics) on a thermal coring drill for drilling in dry holes (Sekurov 1967; Kudryashov et al. 1983).

\section{Traverse Vostok-Pole of Relative Inaccessibility $\left(7^{\circ} \mathrm{S}, 20^{\circ} \mathrm{E}\right)-$ Molodyezhnaya}

Six holes from 37 up to 49 m were drilled from December 1963 to March 1964 (Zotikov et al. 1965). The method of drilling wasn't reported.

\section{4-65, Tenth SAE}

Development work continued by MMI and MIRGEM on a thermal coring drill (Sekurov 1967; Kudryashov et al. 1983).

\section{5-66, Eleventh SAE: Mirny}

In the summer season of 1966, the ETBLK-1M thermal coring drill, designed and built by the MMI and the MIRGEM, were tested at the Mirny observatory. The drill had a heated ring with an outside diameter (OD)/inside diameter (ID) measuring $146 \mathrm{~mm} / 100 \mathrm{~mm}$. It was about 5.25 $\mathrm{m}$ long, weighed about $140 \mathrm{~kg}$, and had provisions for pumping the melt water into a container within the drill. Three dry holes were drilled, with 
the deepest reaching moraine at the bottom of the ice at $77 \mathrm{~m}$. Hole diameters were approximately $150 \mathrm{~mm}$ and core diameters approximately 90 $\mathrm{mm}$. A total of $101 \mathrm{~m}$ was drilled (Sekurov 1967; Kudryashov et al. 1973a; Kudryashov et al. 1983; Zotikov et al. 1974).

\section{6-67, Twelfth SAE: Novolazarev Ice Shelf}

The first penetration of an ice shelf was accomplished with a thermal drill (Korotkevitch 1978). No details of the operation were discussed.

The drawbacks in the design of the thermal drilling system used in the previous season were identified and improvements made under a new cooperative venture between the AARI and the LMI (Kudryashov et al. 1973b; Kudryashov et al. 1983).

\section{7-68, Thirteenth SAE: Mirny}

A new type of thermal drill was tested and further developed during the winter at Mirny. Morev (1972) reported that six holes with a total length of $374.5 \mathrm{~m}$ were drilled by an improved thermal drill referred to as TELGA-2 (Russian abbreviation for "Electrothermal drill constructed by the LMI and the AARI," the number 2 is the modernization number). The TELGA-2 thermal drill worked with the heated head immersed in a water layer. The water filled the bottom part of the hole to a height of 8-14 $\mathrm{cm}$ above the thermal head from where it was pumped into a storage tank. The drill had a heated ring with an OD/ID measuring $150 / 90 \mathrm{~mm}$. The power of the thermal drill head was $3.04 \mathrm{~kW}$. The deepest hole was $212.5 \mathrm{~m}$ and was drilled at the $26 \mathrm{~km}$ mark on the Mirny-Vostok route, August-September 1968. The rate of penetration was $1.37 \mathrm{~m} / \mathrm{h}$ at a depth of $117 \mathrm{~m}$ and 1.65 $\mathrm{m} / \mathrm{h}$ at a depth of $190 \mathrm{~m}$. A total of $386.5 \mathrm{~m}$ of ice was drilled at Mirny Station and along the Mirny-Vostok route (Morev and Shamont'yev 1972; Kudryashov et al. 1994).

\section{8-69, Fourteenth SAE: Mirny}

Two test holes were drilled, one at the Mirny meteorological grounds (34.5 $m$ deep) and one near the runway (34.5 $\mathrm{m}$ deep) with a TELGA-3 thermal drill. Later this thermal drill was renamed TELGA-14 (the number 14 meaning that the drill was modified by members of the 14th Soviet Antarctic Expedition). After the modification the letter " $\mathrm{M}$ " was added, and it became TELGA-14M) (Fig. 3a, Table 1). The leader of the drilling team was 
V.F. Fisenko. The thermal drill head OD/ID dimensions were 178/130 $\mathrm{mm}$. The drill length and weight were $8 \mathrm{~m}$ and $200 \mathrm{~kg}$ respectively. The drill consumed 3 to $3.5 \mathrm{~kW}$ of power, produced a $180-185 \mathrm{~mm}$ diameter hole, a 120-125 mm diameter core, and was suspended from an 18-mmdiameter cable. Melt water was removed by a vacuum system and collected in a tank. The TELGA drill developed by the LMI was in principle based on Barkov's design (Barkov et al. 1973; Korotkevich and Kudryashov 1976). The penetration rate in ice was $1.6-1.8 \mathrm{~m} / \mathrm{h}$ with $10-11 \mathrm{~L}$ of melt water recovered per meter. In October-November of 1969, a dry test hole $250 \mathrm{~m}$ deep was drilled at the 50-km mark of the Mirny-Vostok traverse in 36 days (Kudryashov et al. 1973a; Kudryashov et al. 1983b).

Table 1. Main characteristics of thermal drills.

\begin{tabular}{|l|l|l|l|l|l|l|}
\hline Type & $\begin{array}{l}\text { Maximum } \\
\text { depth } \\
\text { drilled }(\mathrm{m})\end{array}$ & $\begin{array}{l}\text { OD/ID of } \\
\text { drill head } \\
(\mathrm{mm})\end{array}$ & $\begin{array}{l}\text { Power of } \\
\text { drill head } \\
(\mathrm{kW})\end{array}$ & $\begin{array}{l}\text { Length of } \\
\text { core barrel } \\
(\mathrm{m})\end{array}$ & $\begin{array}{l}\text { Length of } \\
\text { drill } \\
(\mathrm{m})\end{array}$ & $\begin{array}{l}\text { Weight of } \\
\text { drill } \\
(\mathrm{kg})\end{array}$ \\
\hline TELGA-14M & 952 & $178 / 130$ & 3.5 & 2.5 & 8.0 & 200 \\
\hline TBZS-152M & 2502 & $152 / 114$ & 3.5 & 3.2 & 7.5 & 180 \\
\hline TBZS-132 & 2755 & $132 / 95$ & 3.0 & 3.0 & 7.2 & 120 \\
\hline TBS-112VCh & 2202 & $112 / 92$ & 4.5 & 2.0 & 9.0 & 180 \\
\hline ETB-3 & 812 & $108 / 84$ & $1-4$ & $1.5-2.7$ & $1.8-3.2$ & $25-60$ \\
\hline ETB-5 & 871.5 & $100 / 82$ & $1.5-3.0$ & 3 & 4 & 60 \\
\hline
\end{tabular}

\section{9-70, Fifteenth SAE: Vostok}

The TELGA-14 drill was brought to Vostok in January 1970. A drill building was constructed on two steel sleds and provided a work area measuring $15 \times 2.9 \times 2.5 \mathrm{~m}$ (Fig. 4). A 9.7-m round tower, measured from the top of the hole, was constructed in the center of the work area and was wrapped in rubberized cloth for protection. The armored cable was a KTGN-10 with six conductors. (Barkov et al. 1973). The first attempt at deep-hole drilling at Vostok was started in April, 1970. A dry hole named Hole (1), reached a depth of $423 \mathrm{~m}$ by 1 August, $503 \mathrm{~m}$ by the end of August and $506.9 \mathrm{~m}$ by September 1970 (Fig. 5, Table 2). In total, 293 drilling runs were completed (Barkov 1970; Barkov et al. 1973; Kudryashov et al. 1973a; Kudryashov et al. 1973b; Dmitriev et al. 1979; Kudryashov et al., 1983b). 


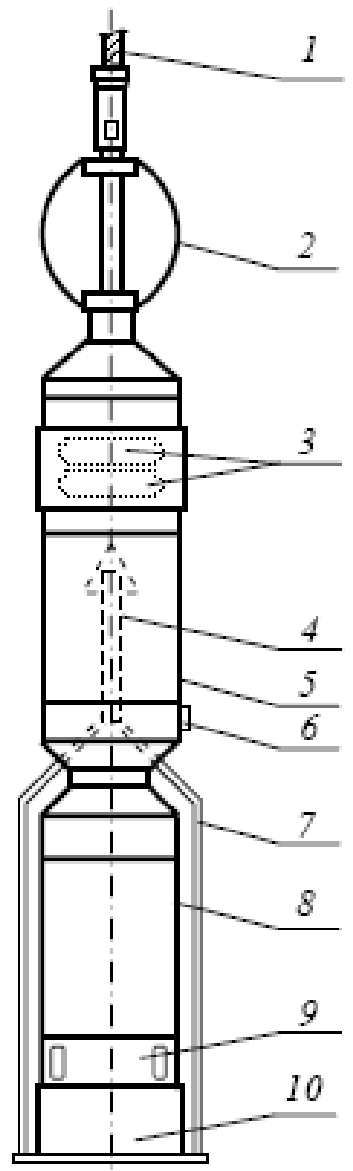

$a$

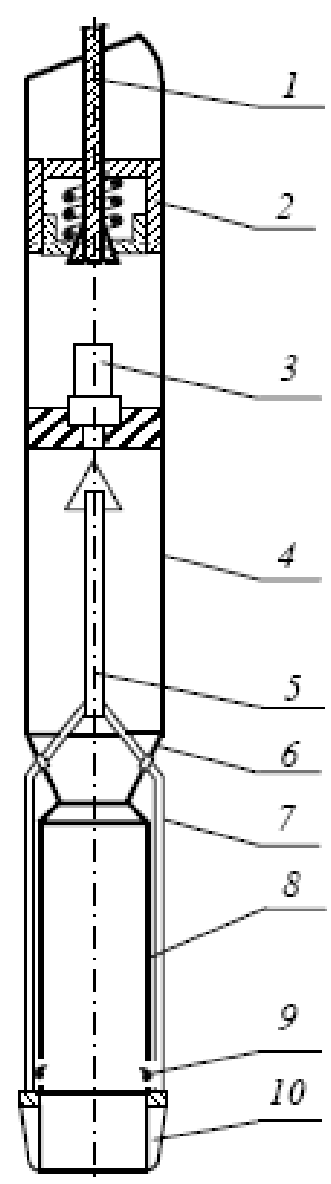

$h$

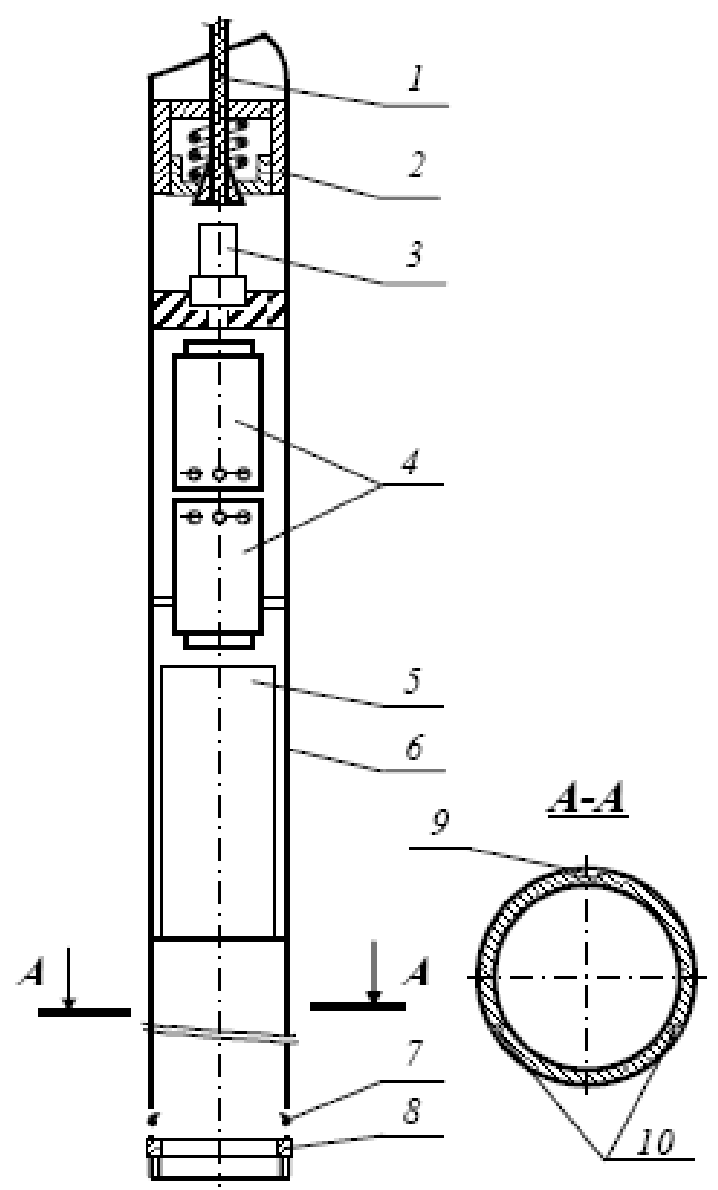

c.

Figure 3. Thermal drills of LMI. a- TELGA-14M Thermal drill: (1) cable, (2) centering springs, (3) vacuum pump, (4) central water suction tube, (5) water tank, (6) valve, (7) water suction tubes, (8) core barrel, (9) core catcher,(10) thermal head. $b$ - TBZS-152M Thermal drill: (1) cable, (2) cable termination, (3) pump, (4) water tank, (5) central water suction tube, (6) connector, (7) water suction tubes, (8) core barrel, (9) core catcher, (10) thermal head. c- TBS-112VCh Thermal drill: (1) cable, (2) cable termination, (3) pump, (4) electrical transformers, (5) removable water tank, (6) core barrel, (7) core catcher, (8) thermal head, (9) electrical lines, (10) water suction tubes.

The most serious difficulty encountered during drilling was contamination of the hole by the impregnated graphite escaping from beneath the cable armor. The graphite settled to the bottom of the hole and impaired the heat transfer from the heating head to the ice reducing the penetration rate by $20-30 \%$. A special $3-\mathrm{kW}$ heating head with a conical shape was used to melt a depression at the bottom of the hole into which the graphite settled. After the melt water had frozen, the ice containing the contaminant was removed as part of a core. This procedure was repeated at depths of $276,346,419$, and $498 \mathrm{~m}$. The contaminant also coated the walls of the water suction tubes and impaired the operation of the pump both of which 
had to be periodically cleaned. Drilling progressed slowly without any other serious complications except for two mishaps.

Table 2 Deep Drilling At Vostok Station.

\begin{tabular}{|c|c|c|c|c|c|c|}
\hline $\begin{array}{l}\text { Expedition } \\
\text { \# (Year) }\end{array}$ & \begin{tabular}{|l|} 
Leader of the \\
drilling team
\end{tabular} & Hole \# & \begin{tabular}{|l|} 
Interval of \\
drilling, $(\mathrm{m})$
\end{tabular} & Type of drill & $\begin{array}{l}\text { Mean rate of } \\
\text { penetration, } \\
(\mathrm{m} / \mathrm{h})\end{array}$ & $\begin{array}{l}\text { Mean length o } \\
\text { run }(\mathrm{m})\end{array}$ \\
\hline \multicolumn{7}{|c|}{ Hole 1} \\
\hline $\begin{array}{l}15 \\
(1970)\end{array}$ & N.I.Barkov & \multirow{5}{*}{1} & $0-506.9$ & \multirow{4}{*}{ TELGA-14 } & 1.34 & 1.73 \\
\hline \multirow{3}{*}{$\begin{array}{l}16 \\
(1971)\end{array}$} & \multirow{3}{*}{ N.I.Slyusarev } & & $506.9-560$ & & \multirow{3}{*}{1.3} & \multirow{3}{*}{1.6} \\
\hline & & & $518-534.4$ & & & \\
\hline & & & $471-625.2$ & & & \\
\hline \multirow{2}{*}{$\begin{array}{l}17 \\
(1972)\end{array}$} & \multirow{2}{*}{ V.K.Chistyakov } & & $625.2-952.4$ & \multirow{4}{*}{ TELGA-14M } & \multirow{2}{*}{1.2} & \multirow{2}{*}{2.3} \\
\hline & & \multirow[t]{2}{*}{ 1-bis } & $30-774$ & & & \\
\hline \multirow{2}{*}{$\begin{array}{l}18 \\
(1973)\end{array}$} & \multirow{2}{*}{ V.I.Kovalenko } & & $774-780.2$ & & \multirow{2}{*}{1.2} & \multirow{2}{*}{2.5} \\
\hline & & 1-2bis & $307-905$ & & & \\
\hline
\end{tabular}

\begin{tabular}{|c|c|c|c|c|c|c|}
\hline $\begin{array}{l}\text { Expedition \# } \\
\text { (Year) }\end{array}$ & $\begin{array}{l}\text { Leader of the } \\
\text { drilling team }\end{array}$ & Hole \# & $\begin{array}{l}\text { Interval of } \\
\text { drilling, (m) }\end{array}$ & Type of drill & $\begin{array}{l}\text { Mean rate } \\
\text { of penetra- } \\
\text { tion, }(\mathrm{m} / \mathrm{h})\end{array}$ & $\begin{array}{l}\text { Mean length of } \\
\text { run }(m)\end{array}$ \\
\hline \multicolumn{7}{|c|}{ Hole 2} \\
\hline $\begin{array}{l}16 \\
(1971)\end{array}$ & N.I.Slyusarev & \multirow{3}{*}{2} & $0-108$ & TELGA-14M & 1.3 & 1.6 \\
\hline $\begin{array}{l}19 \\
(1974)\end{array}$ & B.S.Moiseev & & 108-142 & \multirow{2}{*}{ TBZS-152 } & - & - \\
\hline \begin{tabular}{|l}
20 \\
$(1975)$
\end{tabular} & R.N.Vostretsov & & $142-450.4$ & & 2.6 & 1.55 \\
\hline $\begin{array}{l}21 \\
(1975)\end{array}$ & V.N.Bakhtyukov & 2-bis & 224-? & TBZS-152 & - & - \\
\hline \multicolumn{7}{|c|}{ Hole 3G } \\
\hline \multirow{2}{*}{\begin{tabular}{|l}
25 \\
$(1980)$
\end{tabular}} & \multirow{2}{*}{ V.K.Chistyakov } & \multirow{4}{*}{$3 G$} & $0-112$ & TELGA-14M & - & - \\
\hline & & & 112-1351 & TR7S-152M & 20 & 20 \\
\hline \multirow{3}{*}{$\begin{array}{l}26 \\
(1981)\end{array}$} & \multirow{3}{*}{ E.A.Zagrivny } & & 1351-1500 & 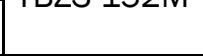 & 2.0 & $<.0$ \\
\hline & & & $1500-1580$ & \multirow{5}{*}{$\begin{array}{l}\text { TBS- } \\
112 \mathrm{VCh}\end{array}$} & \multirow{3}{*}{4.2} & \multirow{3}{*}{1.65} \\
\hline & & \multirow{2}{*}{$3 G-1$} & $1550-2004$ & & & \\
\hline $\begin{array}{l}27 \\
(1982)\end{array}$ & B.S.Moiseev & & 2004-2083 & & & \\
\hline $\begin{array}{l}29 \\
(1984)\end{array}$ & A.V.Krasilev & $3 G-2$ & 1968.5-2040 & & 3.9 & 1.45 \\
\hline \begin{tabular}{|l}
30 \\
$(1985)$
\end{tabular} & A.A.Zemtsov & $3 G-2$ & 2040-2201.7 & & 3.7 & 1.55 \\
\hline
\end{tabular}




\begin{tabular}{|c|c|c|c|c|c|c|}
\hline \begin{tabular}{|l|} 
Expedition \# \\
(Year)
\end{tabular} & $\begin{array}{l}\text { Leader of the } \\
\text { drilling team }\end{array}$ & Hole \# & \begin{tabular}{|l|} 
Interval of \\
drilling, $(\mathrm{m})$
\end{tabular} & Type of drill & \begin{tabular}{|l|} 
Mean rate \\
of penetra- \\
tion, $(\mathrm{m} / \mathrm{h})$
\end{tabular} & $\begin{array}{l}\text { Mean length of } \\
\text { run }(m)\end{array}$ \\
\hline \multicolumn{7}{|c|}{ Hole 4G } \\
\hline \multirow{2}{*}{$\begin{array}{l}28 \\
(1983)\end{array}$} & \multirow{2}{*}{ A.M.Shkurko } & \multirow{3}{*}{$4 G$} & $0-120$ & TELGA-14M & 2.0 & - \\
\hline & & & \begin{tabular}{|l|}
$120-279$ \\
\end{tabular} & TBZS-152M & 1.9 & 2.18 \\
\hline \begin{tabular}{|l}
29 \\
$(1984)$
\end{tabular} & A.V.Krasilev & & - & - & - & - \\
\hline \multirow{2}{*}{$\begin{array}{l}30 \\
(1985)\end{array}$} & \multirow{2}{*}{ A.A.Zemtsov } & \multirow{3}{*}{ 4G-1 } & 120-167 & TELGA-14M & - & - \\
\hline & & & \begin{tabular}{|l|}
$167-692$ \\
\end{tabular} & TR7s 150 & 1.3 & 1.8 \\
\hline \multirow{3}{*}{\begin{tabular}{|l}
31 \\
$(1986)$
\end{tabular}} & \multirow{3}{*}{$\begin{array}{l}\text { V.P.Lobanov, } \\
\text { B.S.Moiseev }\end{array}$} & & 692-752 & $10 \angle 0-10<1 \sqrt{1}$ & 1.3 & 2.3 \\
\hline & & \multirow{6}{*}{$4 G-2$} & 159-201 & TELGA-14M & - & - \\
\hline & & & \begin{tabular}{|l|}
$201-779$ \\
\end{tabular} & & 1.2 & 2.05 \\
\hline \begin{tabular}{|l|}
32 \\
$(1987)$
\end{tabular} & A.V.Krasilev & & 779-1502 & 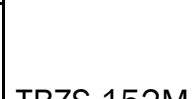 & 2.05 & 2.25 \\
\hline \begin{tabular}{|l}
33 \\
$(1988)$
\end{tabular} & S.L.Mitin & & 1502-2383 & $10 \angle O-\perp 0 \angle T V$ & 2.1 & 3.0 \\
\hline \multirow{2}{*}{$\begin{array}{l}34 \\
(1989)\end{array}$} & \multirow[b]{2}{*}{ N.I.Vasiliev } & & \begin{tabular}{|l|}
$2383-2428.5$ \\
\end{tabular} & & 2.3 & 2.9 \\
\hline & & & \begin{tabular}{|l|}
$2428.5-$ \\
2546.4
\end{tabular} & KEMS-112 & 12.5 & 2.5 \\
\hline \multicolumn{7}{|c|}{ Hole 5G } \\
\hline \multirow{2}{*}{$\begin{array}{l}35 \\
(1990)\end{array}$} & \multirow{2}{*}{ A.A.Zemtsov } & \multirow{3}{*}{$5 G$} & $0-120$ & TELGA-14M & 1.8 & 1.9 \\
\hline & & & \begin{tabular}{|l|}
$120-1279.8$ \\
\end{tabular} & \multirow[b]{2}{*}{ TBZS-152 } & 2.1 & 2.9 \\
\hline $\begin{array}{l}36 \\
(1991)\end{array}$ & A.V.Krasilev & & \begin{tabular}{|l|}
$1279.8-$ \\
2502.7
\end{tabular} & & 2.3 & 3.0 \\
\hline \multirow{2}{*}{\begin{tabular}{|l}
37 \\
$(1992)$
\end{tabular}} & \multirow[b]{2}{*}{ B.S.Moiseev } & \multirow{8}{*}{ 5G-1 } & 2232-2249.5 & \multirow{3}{*}{ TBZS-132 } & 2.0 & 1.0 \\
\hline & & & \begin{tabular}{|l|}
$2249.5-$ \\
2270.7
\end{tabular} & & 2.0 & 2.0 \\
\hline \begin{tabular}{|l|}
38 \\
$(1993)$
\end{tabular} & V.K.Chistyakov & & \begin{tabular}{|l|}
$2270.7-$ \\
2755.3
\end{tabular} & & 1.8 & 2.5 \\
\hline \begin{tabular}{|l|}
40 \\
$(1995)$
\end{tabular} & N.I.Vasiliev & & 2755.3-3109 & & 8.0 & 2.5 \\
\hline $\begin{array}{l}41 * \\
(1995 / 96)\end{array}$ & N.I.Vasiliev & & 3109-3350 & KEMS-132 & 8.0 & 2.2 \\
\hline $\begin{array}{l}42^{*} \\
(1997 / 98)\end{array}$ & N.I.Vasiliev & & 3350-3523 & & 8.0 & 2.1 \\
\hline $\begin{array}{l}43^{*} \\
(1997 / 98)\end{array}$ & N.I.Vasiliev & & 3523-3623 & & 8.0 & 1.8 \\
\hline $\begin{array}{l}51^{*} \\
2005 / 06\end{array}$ & N.J.Vasiliev & & 3623-3650.2 & KEMS-135 & & \\
\hline
\end{tabular}

*The drilling was conducted during the Austral summer only. 
The first occurred at a depth of $15.7 \mathrm{~m}$ while replacing a pump. The drill was partially lowered into the hole and held with clamps. Problems with the clamps resulted in a section of drill dropping to the bottom of the hole. The section was retrieved by using an adapter on the end of a column of rods, which was threaded into the broken section. The operation took about six hours.

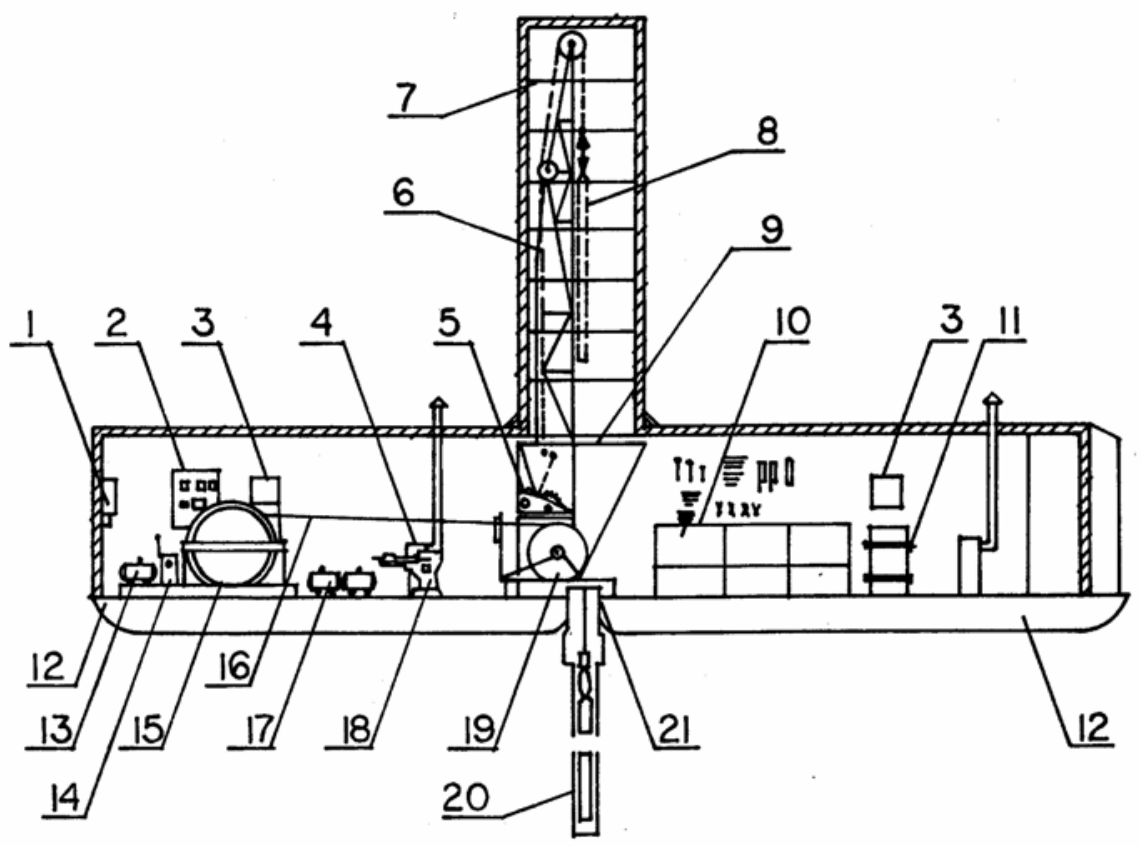

Figure 4. Schematic diagram of the electro-thermal drilling equipment at Vostok Station. (1) electrical switchboard, (2) control panel, (3) window aperture, (4) oil furnace, (5) auxiliary hoist, (6) rig, (7) tower rings, (8) installation of the drill over the hole, (9) supporting framework, (10) bench and instruments, (11) fire prevention apparatus, (12) steel sled, (13) hoist motor, (14) two-speed gear reducer, (15) main hoist, (16) cable, (17) generator-motor system, (18) lathe, (19) collapsible balance block, (20) drill in the hole, (21) conductor (from Korotkevich and Kudryashov 1976). 


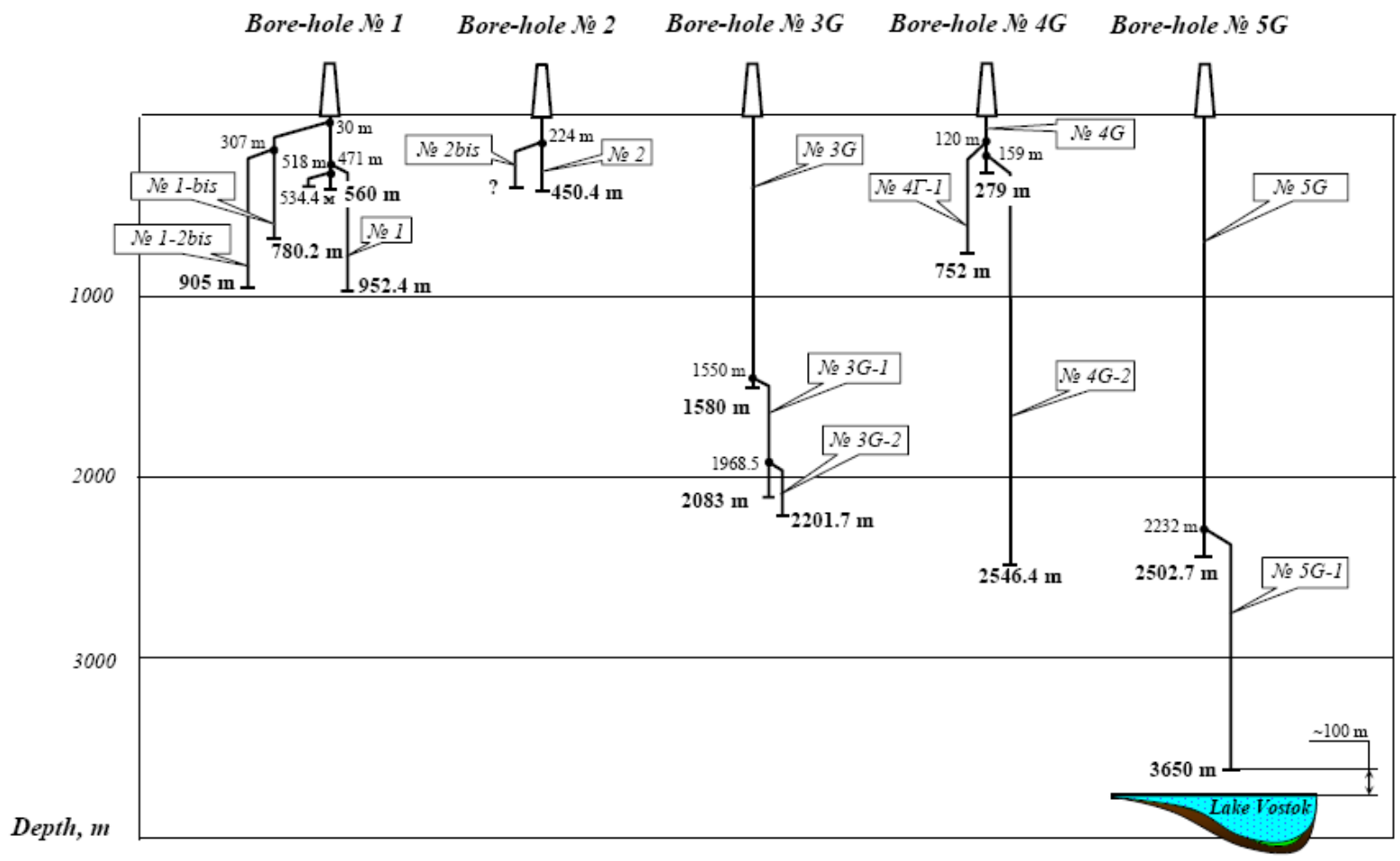

Figure 5. Schematic of deep holes at Vostok Station drilled by LMI, SPSMI.

At a depth of $497.4 \mathrm{~m}$, a 20-cm steel rod was accidentally dropped to the bottom of the hole. A special heater assembly was used to melt a small central hole, which repositioned the rod from an inclined to a more vertical position. In this position the rod would fit within the annular heating head of the TELGA drill. It was then recovered atop the next core. The operation took 14 days. (Barkov et al. 1973; Fisenko et al. 1974).

\section{0-71, Sixteenth SAE: Vostok}

Drilling of Hole (1) continued. At the beginning of winter, owing to the carelessness of the drillers, the TELGA-14 drill unattached to a cable was dropped to the bottom of the hole. Using special grips, the drill was recovered (Fisenko et al. 1974). Later, at a depth of $560 \mathrm{~m}$, as the drill was being hoisted, it became stuck near the bottom of the hole, probably because of the inadequate removal of melt water. A whip-stock with a length of $4.5 \mathrm{~m}$ was set at a depth of $505 \mathrm{~m}$ and directional drilling began using a short thermal drill (total length of $2 \mathrm{~m}$ ) with a conical drill head. A new off-set hole was started from a depth of $518 \mathrm{~m}$. To ensure the free passage of the longer thermal drill, the deviated interval of the hole was enlarged, but unfortunately the old hole was reopened in the process. From that time on, the drill sometimes entered the new hole and sometimes the old one. At a 
depth of $534.4 \mathrm{~m}$ the drilling of the off-set hole was stopped. The interval near-the bottom of the hole was filled with ice up to a depth of $471 \mathrm{~m}$ and a new directional drilling effort was started without using a whip-stock. The deviation was accomplished using a thermal drill with a special asymmetrical thermal head. This technique was tried by Morev, (1966) while testing thermal drills at Mirny during the 6th SAE. By the end of winter the depth of Hole (1) reached 625.2 m.

During the summer season the drill building was reconstructed and extended to a length of nearly $30 \mathrm{~m}$ (Fig. 6). A special square tower with a height of $17.7 \mathrm{~m}$ was built in the central part of the extended building. From this new setup, an experimental Hole (2) was drilled to $108 \mathrm{~m}$ using a TELGA-14 thermal drill for the main purpose of testing a new electromechanical drill, KEMS-152 (KEMS is the Russian abbreviation for "electro-mechanical core drill") designed by G.K. Stepanov. The experiments were to be conducted by N.I. Slyusarev but were not carried out because of imperfections in the new drill (Kudryashov et al. 1973b; Kudryashov et al. 1991; Talalay, personal recollections).

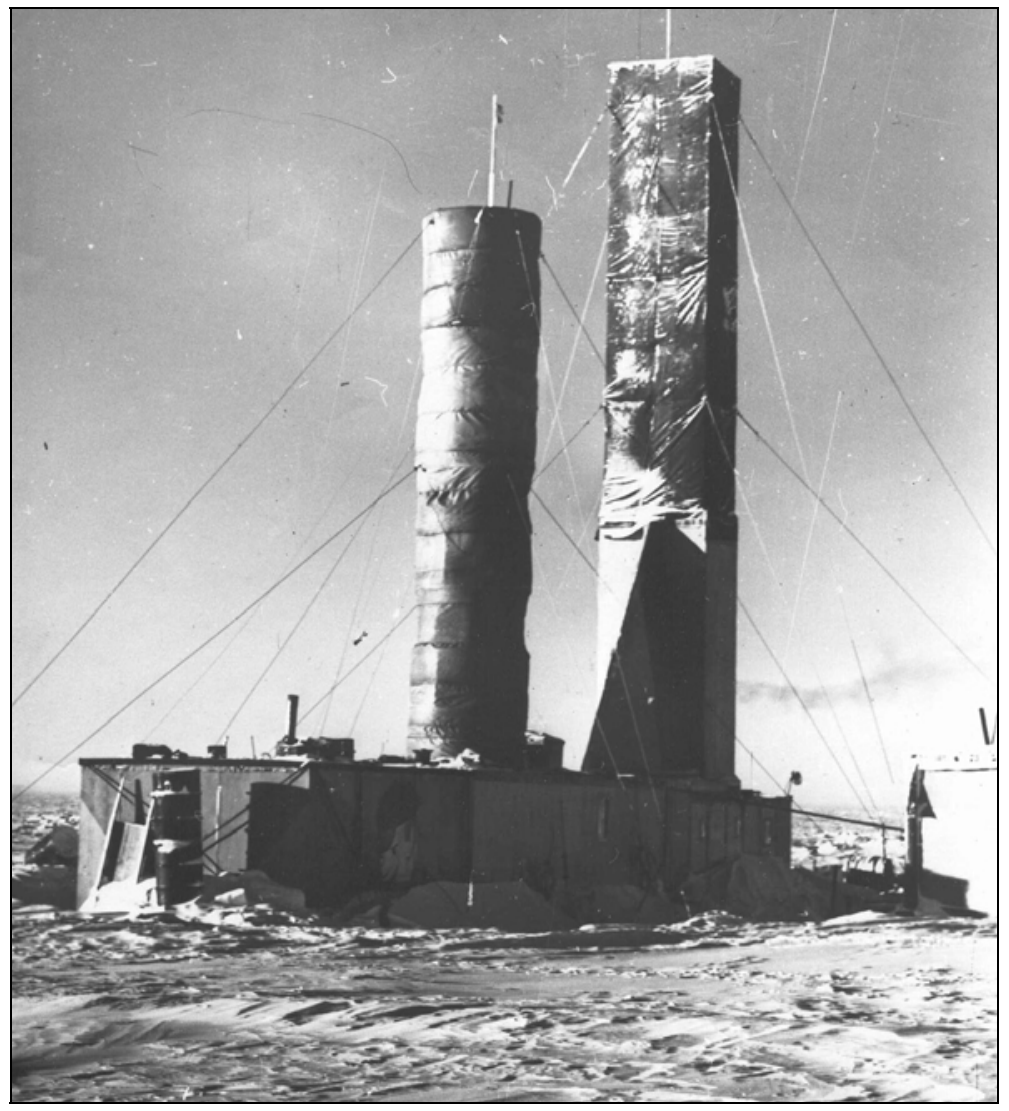

Figure 6. Drill building at Vostok station in the summer season of the $17^{\text {th }}$ SAE (photograph by N.E. Bobin). 


\section{1-72, Seventeenth SAE}

\section{Vostok}

Drilling of Hole (1) was continued from the depth of $625.2 \mathrm{~m}$ using the modified TELGA-14M drill. From the depth of $920 \mathrm{~m}$, drilling was conducted using a spliced cable because the necessary length of cable was not available at the station. The lowering and hoisting was accompanied by repetitive jerking and sticking in the narrow parts of the hole (occurring 30 times during one run). Nevertheless, the hole reached 952.4 $\mathrm{m}$ in May 1972, the deepest dry hole in ice (Korotkevich and Kudryashov 1976; Kudryashov 1989). The final run occurred while the drill was being lowered to the bottom of the hole when the winch brake mechanism failed. The drill dropped to the bottom of the hole followed by the cable, which eventually became detached from the clamp holding it to the winch drum and was thrown into the hole. The drill and all of the cable were eventually left in the hole.(V.K.Chistyakov, leader of the Vostok drilling team in the $17^{\text {th }}$ SAE, personal communication, 2004). A new offset hole was started. A cylindrical piece of ice was dropped from the surface into the hole, but unfortunately it got stuck at a depth of $30 \mathrm{~m}$ and efforts to dislodge it failed (Fisenko et al. 1974). From this depth a new off-set hole named Hole (1bis) was started and eventually reached a depth of $774 \mathrm{~m}$ (Kudryashov et al. 1975; Kudryashov et al. 1977).

\section{Mirny}

A traverse on the Mirny-Vostok route was conducted during the summer by LMI with a TELGA-14M thermal coring drill mounted in a new mobile drilling shelter. The unit drilled down to $50.5 \mathrm{~m}$ at the $57-\mathrm{km}$ mark and $56.6 \mathrm{~m}$ at the $153-\mathrm{km}$ mark (Table 3 ). Drilling rates varied from 2.0-3.75 $\mathrm{m} / \mathrm{h}$ and core diameters were $123-125 \mathrm{~mm}$.

Table 3. LMI drilling on the Mirny-Vostok Route.

\begin{tabular}{|l|l|l|l|l|}
\hline $\begin{array}{l}\text { Expedition \# } \\
(\text { Season years) }\end{array}$ & Site & $\begin{array}{l}\text { Leader of the } \\
\text { drilling team }\end{array}$ & Depth $(\mathrm{m})$ & Type of drill \\
\hline $\begin{array}{l}17 \\
(1971-1972)\end{array}$ & $57 \mathrm{~km}$ & \multirow{2}{*}{ N.E.Bobin } & 50.5 & TELGA-14M \\
\cline { 2 - 5 } & $153 \mathrm{~km}$ & 56.5 & TELGA-14M \\
\hline $\begin{array}{l}18 \\
(1972-1973)\end{array}$ & $353 \mathrm{~km}$ & L.K.Gorshkov & 76 & TELGA-14M \\
\hline $\begin{array}{l}20 \\
(1974-1975)\end{array}$ & $\begin{array}{l}\text { Vostok-1 } \\
(647 \mathrm{~km})\end{array}$ & B.B.Kudryashov & 105.3 & TELGA-14M \\
\hline
\end{tabular}




\begin{tabular}{|c|c|c|c|c|}
\hline $\begin{array}{l}\text { Expedition \# } \\
\text { (Season years) }\end{array}$ & Site & $\begin{array}{l}\text { Leader of the } \\
\text { drilling team }\end{array}$ & Depth (m) & Type of drill \\
\hline $\begin{array}{l}21 \\
(1975-1976)\end{array}$ & $\begin{array}{l}\text { Vostok-1 } \\
(647 \mathrm{~km})\end{array}$ & V.I.Kovalenko & $0-181$ & TELGA-14M \\
\hline $\begin{array}{l}22 \\
(1976-1977)\end{array}$ & $\begin{array}{l}\text { Vostok-1 } \\
(647 \mathrm{~km})\end{array}$ & N.E.Bobin & $181-304$ & TELGA-14M \\
\hline $\begin{array}{l}23 \\
(1977-1978)\end{array}$ & $\begin{array}{l}\text { Vostok-1 } \\
(647 \mathrm{~km})\end{array}$ & B.S.Moiseev & $304-430$ & TELGA-14M \\
\hline \multirow{3}{*}{$\begin{array}{l}24 * \\
(1978)\end{array}$} & \multirow{3}{*}{$\begin{array}{l}\text { Base Gornaya } \\
(73 \mathrm{~km})\end{array}$} & \multirow{3}{*}{ N.E.Bobin } & $0-430.3$ & TELGA-14M \\
\hline & & & $430.3-721$ & TBZS-152M \\
\hline & & & $500-750$ & TBZS-152M \\
\hline $\begin{array}{l}24 \\
(1978-1979)\end{array}$ & $\begin{array}{l}\text { Pionerskaya } \\
(375 \mathrm{~km})\end{array}$ & B.B.Kudryashov & 137.5 & TELGA-14M \\
\hline $\begin{array}{l}25 \\
(1978-1979)\end{array}$ & $\begin{array}{l}\text { Pionerskaya } \\
(375 \mathrm{~km})\end{array}$ & B.S.Moiseev & 375 & TELGA-14M \\
\hline $\begin{array}{l}26 \\
(1978-1979)\end{array}$ & $\begin{array}{l}1045 \mathrm{~km} \text { on the Mirny- } \\
\text { Pionerskaya-Dome C } \\
\text { route }\end{array}$ & V.N.Vasiliev & 306 & TELGA-14M \\
\hline \multirow{2}{*}{$\begin{array}{l}33 \\
(1987-1988)\end{array}$} & \multirow{2}{*}{105 km } & \multirow{2}{*}{ V.N.Vasiliev } & $0-527$ & TELGA-14M \\
\hline & & & $527-740$ & TBZS-152M \\
\hline \multirow{3}{*}{$\begin{array}{l}34 \\
(1988-1989)\end{array}$} & $60 \mathrm{~km}$ & \multirow{3}{*}{ V.N.Vasiliev } & 150.5 & TELGA-14M \\
\hline & $140 \mathrm{~km}$ & & 150 & TELGA-14M \\
\hline & $200 \mathrm{~km}$ & & 150.8 & TELGA-14M \\
\hline \multirow{3}{*}{$\begin{array}{l}35 \\
(1989-1990)\end{array}$} & $260 \mathrm{~km}$ & \multirow{3}{*}{ B.S.Moiseev } & 150 & TELGA-14M \\
\hline & $325 \mathrm{~km}$ & & 150 & TELGA-14M \\
\hline & $400 \mathrm{~km}$ & & 150 & TELGA-14M \\
\hline
\end{tabular}

${ }^{*}$ Drilling was conducted during the winter.

In addition, tests were made on electric needles designed by AARI for the drilling of holes $80 \mathrm{~mm}$ in diameter for seismic purposes. Thirty four holes from 6 to $26.5 \mathrm{~m}$ deep (a total of $358.4 \mathrm{~m}$ ) were drilled at a penetration rate of 7-10 m/hr (Kudryashov et al. 1973b; Bobin et al. 1974).

\section{2-73, Eighteenth SAE}

\section{Vostok}

Kudrayshov et al. (1991) reported the drilling depth in Hole (1-bis) as 774$780.2 \mathrm{~m}$ when the hole became inaccessible owing to an accident during hoisting. The thermal head was stuck near the bottom and separated from the drill at a depth of $762 \mathrm{~m}$. The drill itself had been stuck at a depth of $308 \mathrm{~m}$ (Vartykyan et al. 1977). V.K. Chistyakov (personal communication, 2004) recalls that the main reason for the accident was the inexperience of 
the new team, who did not recognize problems with the pumping of melt water at the bottom of the hole. Ultimately, this led to the drill becoming stuck during hoisting (the drill profile "swelled" because of refrozen water on its surface) during one of the first runs carried out by the new drilling team of the $18^{\text {th }}$ SAE.

A new off-set Hole (1-2bis) was started at a depth of $307 \mathrm{~m}$ in the original hole and reached a depth of $905 \mathrm{~m}$ (Kudryashov et al. 1977; Kudryashov et al. 1991). Further drilling was stopped owing to the high risk of getting the drill stuck.

The first thermal coring drill for use in a fluid-filled hole, TBZS-152 (Fig. 3b, Table 1), was developed by LMI (Leningrad Mining Institute) in 1973. TBZS-152 is the Russian abbreviation for a "thermal drill for fluid-filled holes," the number 152 signifies the outer diameter of the drill head in millimeters. After modifications, the name of the TBZS-152 drill was followed by the letter "M." The drill head OD/ID dimensions were 152/114 mm. It contained a pump and a tank to store the collected melt water. The drill length and weight were $7.5 \mathrm{~m}$ and $180 \mathrm{~kg}$ respectively. Power consumption was 2.5 to $5 \mathrm{~kW}$ (Kudryashov 1989).

\section{Mirny}

A traverse to the 353-km mark on the Mirny-Vostok route was conducted during the summer, where a TELGA-14M drilled a 76-m hole in 7 days (Kudryashov et al. 1991).

\section{3-74, Nineteenth SAE: Vostok}

A casing was set into place in Hole (2), which had been drilled during the $16^{\text {th }} \mathrm{SAE}$ to a depth of $108 \mathrm{~m}$ for experiments. The casing was made from steel tubing with an OD/ID of 168/154 $\mathrm{mm}$. The main problem was sealing the lower part of the casing to the ice (B.S. Moiseev, Leader of the Vostok drilling team in the $19^{\text {th }} \mathrm{SAE}$, personal communication, 2004). Water was poured into the hole from the surface. Hardly any of it reached the bottom because most of it froze on the inner surface of the casing. After the casing was cleaned, the hole was filled with a water-ethanol solution. It is not known whether the casing was sealed to the ice.

The first attempts to drill in a deep fluid filled hole using a TBZS-152 thermal drill and a water-ethanol solution as the hole fluid encountered 
many problems (Kudryashov 1983; Kudryashov 1989). Owing to the dissolution of ice from the bore-hole walls, the concentration of the waterethanol solution decreased and formed an icy slush. This may have been attributable to an overly rich concentration dissolving the ice and the subsequent precipitation of the ice as the solution cooled to equilibrium temperatures. This hindered drill penetration. In total the interval of 108-142 $\mathrm{m}$ was drilled with a mean ethanol consumption of $50 \mathrm{~L} / \mathrm{m}$ (sic) (Kudryashov et al. 1983b; Kudryashov et al. 1991) because of the low ice temperatures inexperience in the use of water-ethanol solutions.

\section{4-75, Twentieth SAE}

\section{Vostok}

The drilling liquid in Hole (2) was changed to a kerosene type of aircraft fuel, TS-1. During drilling, the liquid level was kept at a depth of 130-150 $\mathrm{m}$. Drilling continued with the TBZS-152 thermal drill down to $450.4 \mathrm{~m}$, where the drill became stuck owing to the inadequate removal of melt water at the bottom of the hole (Zagrivny et al. 1981; Kudryashov et al. 1983b). During the attempt to free the drill, the cable was ruptured.

In the interval from 142-450.4 m, 199 drilling runs were completed with the following mean parameters: core length $1.55 \mathrm{~m}$ and penetration rate $2.6 \mathrm{~m} / \mathrm{h}$. The power of the copper drill head was $6 \mathrm{~kW}$, and the power of the aluminum drill head was $5.3 \mathrm{~kW}$. The power of the heating elements in the water suction tubes was $120 \mathrm{~W} / \mathrm{m}$, the power of the heating elements in the water tank was $1.5 \mathrm{~kW} / \mathrm{m}$ of water column (Zagrivny et al. 1980).

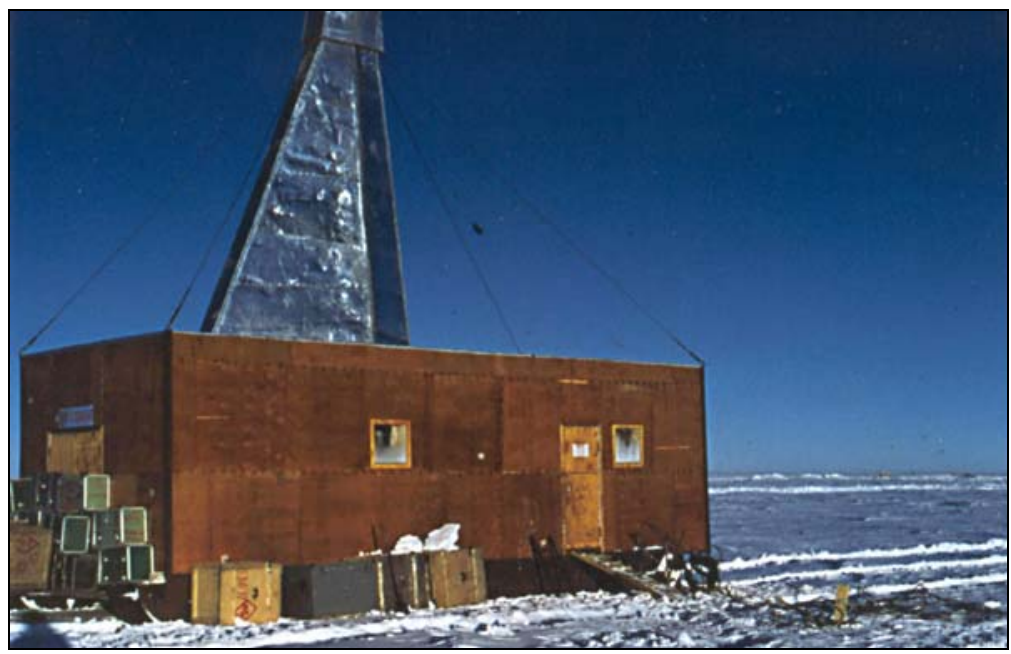

Figure 7. Microbiological drilling building at Vostok Station (photograph by N.E. Bobin). 
In November 1974, a special microbiological drilling building (measuring $9 \times 3.7 \times 2.5 \mathrm{~m}$ and mounted on a metal sled, Fig. 7) with an A-shaped, 7-m mast was transported from Mirny to Vostok. Besides the drilling facilities, it contained a laboratory section for the microbiological sampling of ice cores. In February, 1975 the special hole MB-1 for microbiological investigations was drilled at a site $400 \mathrm{~m}$ to the west of Vostok Station. The hole MB-1 was drilled to the depth of $105 \mathrm{~m}$ by a TELGA-14M thermal drill that was sterilized before each run (Kudryashov et al. 1978).

The 905-m dry Hole (1-2bis) was made available and scientific observations of the temperature, deviation from the vertical, and wall deformation of the hole began (Korotkevich et al. 1976, Dmitriev et al. 1978).

\section{Vostok-1 (72 ${ }^{\circ} 8^{\prime} \mathrm{S}, 9^{\circ} 3^{3} 5^{\prime} \mathrm{E}, 647 \mathrm{~km}$ mark on the Mirny-Vostok route)}

From 2 February to 8 March 1975, a traverse to Vostok-1 was conducted. Vostok-1 operated as a wintering station during the $1^{\text {st }} \mathrm{CAE}$. Then it was used as a temporary base on the route from Mirny to Vostok. A 105.3-m hole was drilled in 7 days during the summer season with a TELGA-14M drill (Kudryashov et al. 1991).

\section{Mirny}

The first experiments using a thermal drill in an ethanol-water solution where the melt water goes into solution and remains in the hole, took place on the edge of the Antarctic ice sheet in the region of Mirny Station (Morev et al., 1989), probably using an ETB-1 drill (Fig. 8a). ETB-1 is the abbreviation for electro-thermal drill and 1 is a modification number.

\section{Lazarev Ice Shelf*}

A glacier shelf was penetrated with a thermal drill in a fluid-filled hole. The site $\left(70^{\circ} 22.8^{\prime} \mathrm{S}, 12^{\circ} 21.4^{\prime} \mathrm{E}\right)$ was situated approximately $50 \mathrm{~km}$ to the north of Schirmacher Oasis. A 374-m-deep hole was drilled to bedrock from 10 July to 6 August 1975 using a ETB-3 thermal coring drill (Fig. 8b, Table 4). The hole was drilled using an alcohol-water solution that dissolved the melt water and remained in the hole providing the necessary hydrostatic pressure compensation. The mean rate of penetration was nearly $5 \mathrm{~m} / \mathrm{h}$. The drill head OD/ID dimensions were $108 / 84 \mathrm{~mm}$

\footnotetext{
* In some references this shelf is referred to as Novolazarev Ice Shelf.
} 
(Kudryashov et al. 1983b). Later, the drill was called an AFTD (Anti-Freeze Thermal Drill, also referred to as ATED, Anti-Freeze Thermal Electric Drill). The hole and core diameters were $110-112$, and 78-80 mm respectively. The drill was suspended from a single conductor cable with double braided steel outer armor.

From 18 Octber to 15 November, a second hole, $25 \mathrm{~km}$ northwest of the first hole, was drilled to a depth of $357 \mathrm{~m}$ that penetrated to the sea at (70 ${ }^{\circ} 13.2^{\prime} \mathrm{S}, 11^{\circ} 53.3^{\prime} \mathrm{E}$ ) (Morev 1976; Korotkevitch et al. 1978; Morev et al. 1989).
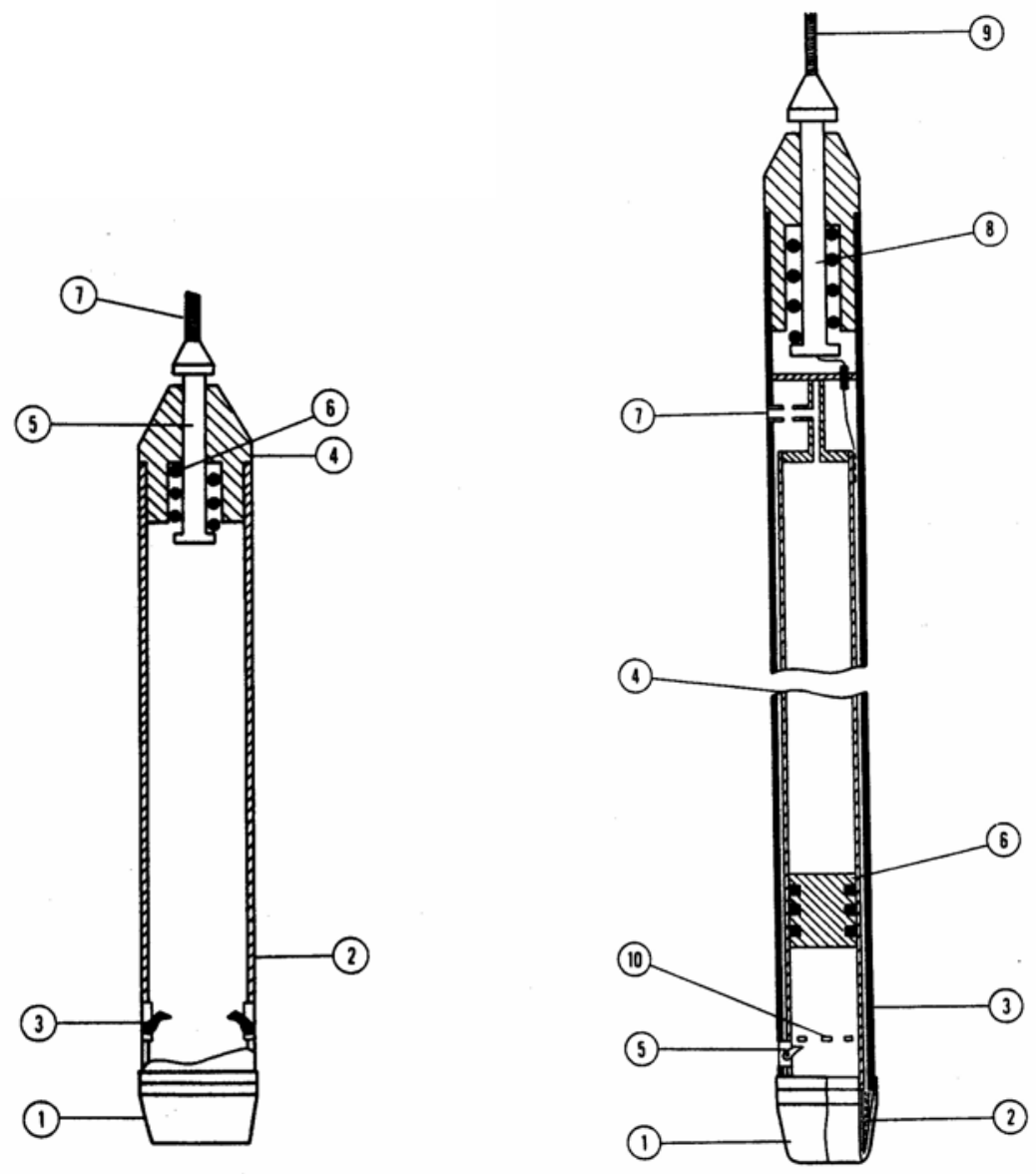

Figure 8. a-ETB-1 electro-thermal core drill. (1) heater shoe, (2) core barrel, (3) core grippers, (4) end cap assembly, (5) cable termination unit, (6) spring, (7) electro-mechanical cable. (from Morev et al. 1984). b-ETB-3 electro-thermal core drill. (1) heater shoe, (2) nichrome heater wire winding, (3) outer barrel, (4) inner core barrel, (5) core grippers, (6) sliding piston, (7) inlet for injecting anti-freeze into the core barrel, (8) spring loaded cable termination assembly, (9) electro-mechanical cable (from Bogorodsky and Morev 1984). 
Table 4. AARI and IGRAS drilling with anti-freeze thermal electric drills.

\begin{tabular}{|c|c|c|c|c|}
\hline $\begin{array}{l}\text { Expedition \# } \\
\text { (Year) }\end{array}$ & Site & $\begin{array}{l}\text { Leader of the drilling } \\
\text { team }\end{array}$ & Depth, m & Type of drill \\
\hline $\begin{array}{l}20 \\
(1975)\end{array}$ & Lazarev Ice Shelf & $\begin{array}{l}\text { L.M.Savatyugin } \\
\text { L.N.Manevsky }\end{array}$ & $\begin{array}{l}374 \\
357\end{array}$ & ETB-3 \\
\hline $\begin{array}{l}21 \\
(1976)\end{array}$ & Lazarev Ice Shelf & V.D.Utyanov & 447 & ETB-3 \\
\hline $\begin{array}{l}22 \\
(1977)\end{array}$ & $\begin{array}{l}40 \mathrm{~km} \text { from } \\
\text { Novolazarevskaya Station }\end{array}$ & L.N.Manevsky & 812 & ETB-3 \\
\hline $\begin{array}{l}23 \\
(1977- \\
1978)\end{array}$ & Shackleton Ice Shelf & L.M.Savatyugin & 195.7 & ETB-3 \\
\hline 1978* & Ross Ice Shelf & I.A.Zotikov & 416 & ETB-3 \\
\hline $\begin{array}{l}25 \\
(1980)\end{array}$ & $\begin{array}{l}\text { Base Pobeda } \\
\text { (43 km from Mirny) }\end{array}$ & L.M.Savatyugin & 387 & ETB-5 \\
\hline 26 & $\begin{array}{l}\text { Komsomolskaya Station } \\
\text { (870 km from Mirny) }\end{array}$ & L.M.Savatyugin & 73 & ETB-5 \\
\hline $\begin{array}{l}1980- \\
1981)\end{array}$ & Mirny & L.N.Manevsky & $\begin{array}{l}5 \text { holes } \\
\text { from } 16 \text { to } 36 \mathrm{~m}\end{array}$ & $\begin{array}{l}\text { ETB-140, } \\
\text { ETB-5 }\end{array}$ \\
\hline $\begin{array}{l}27 \\
(1981- \\
1982)\end{array}$ & \multirow{2}{*}{$\begin{array}{l}\text { Komsomolskaya Station } \\
\text { (870 km from Mirny) }\end{array}$} & $\begin{array}{l}\text { L.N.Manevsky, } \\
\text { V.M.Yakovlev }\end{array}$ & $0-800.6$ & \multirow{2}{*}{ ETB-140, ETB-5 } \\
\hline $\begin{array}{l}28 \\
(1982- \\
1983)\end{array}$ & & L.N.Manevsky & $800.6-871.5$ & \\
\hline $\begin{array}{l}31 \\
(1985- \\
1986)^{*}\end{array}$ & Dome B & A.G.Nikiforov & $92 * *$ & $\begin{array}{l}\text { ETB-140, } \\
\text { ETB-130 }\end{array}$ \\
\hline $\begin{array}{l}33 \\
(1987- \\
1988)\end{array}$ & Dome B & L.N.Manevsky & $780 * *$ & ETB-130 \\
\hline $\begin{array}{l}33 \\
(1988- \\
1989)\end{array}$ & Emery Ice Shelf & Yu.V.Raikovsky & 252 & ETB-3 \\
\hline
\end{tabular}

*The drilling was performed as part of the Ross Ice Shelf Project (RISP) funded by NSF (USA).

**Holes drilled with dry hole thermal drills.

\section{5-76, Twenty-first SAE}

\section{Vostok}

A new off-set Hole (2-bis) was started at a depth of $224 \mathrm{~m}$ in the original Hole (2) but the drill became stuck again. The final depth of Hole (2-bis) was not reported. 
In January-Februay 1976 the microbiological hole MB-1 drilled during the $20^{\text {th }} \mathrm{SAE}$ (400 $\mathrm{m}$ to the west of Vostok Station) was deepened by a TELGA$14 \mathrm{M}$ thermal drill from 105 to $207 \mathrm{~m}$ with a mean rate of penetration of $1.19 \mathrm{~m} / \mathrm{h}$. The mean core length was $1.3 \mathrm{~m}$ and the core diameter was 125 mm (Kudryashov et al. 1978; Sedov 1981).

\section{Vostok-1}

From 25 January to 6 March 1976, a traverse Mirny-Vostok-1-Mirny was conducted. At Vostok-1 from 12 to 20 February, a 181-m hole was drilled with a TELGA-14M drill with the following parameters: mean penetration rate $1.67 \mathrm{~m} / \mathrm{h}$; core length $1.5 \mathrm{~m}$ down to the depth of $130 \mathrm{~m}$ and then 1.3 $\mathrm{m}$ in deeper ice. A total of 129 runs were carried out (Kovalenko et al. 1981).

\section{Lazarev Ice Shelf}

From 12 June to 22 August 1976, a third hole to the south of the second hole was drilled with an AFTD ETB-3 thermal drill and reached the sea at a depth of $447 \mathrm{~m}$ at $70^{\circ} 23.6^{\prime} \mathrm{S}, 11^{\circ} 39.6^{\prime} \mathrm{E}$ (Korotkevich et al. 1978; Morev and Raikovsky 1979; Bardin 1982).

\section{6-77, Twenty-second SAE}

\section{Vostok}

Experiments with a TBZS-152 thermal drill were continued. Two holes with depths of 171 and $300 \mathrm{~m}$ were drilled. Drilling was difficult, and a few serious accidents occurred (Savatyugin and Preobrazhenskaya 2000).

In February, 1977 the microbiological hole MB-1 drilled during the $20^{\text {th }}$ and $21^{\text {st }}$ SAE was deepened with a TELGA-14M thermal drill from 207 to $312 \mathrm{~m}$ (Kudryashov et al. 1978).

\section{Vostok-1}

In February 1977 the hole drilled during the $21^{\text {st }}$ SAE was continued with a TELGA-14M drill from a depth of $181 \mathrm{~m}$ to $304 \mathrm{~m}$ in 12 days (Kudryashov et al. 1991). 


\section{Novolazarevskaya Station}

At the beginning of June 1977, to study the stability of the holes that were drilled on the Lazarev Ice Shelf during the $20^{\text {th }} \mathrm{SAE}$, an attempt was made to find Hole-1, but it was not successful.

An AFTD core drilled $812 \mathrm{~m}$, including $62 \mathrm{~m}$ of firn, at a site $40 \mathrm{~km}$ to the south of Novolazarezkaya Station $\left(70^{\circ} 58^{\prime} \mathrm{S}, 11^{\circ} 22^{\prime} \mathrm{E}\right)$. The thickness of the ice measured by echo soundings was near $1000 \mathrm{~m}$. The drilling took place from 23 July to 19 October 1977. A special thermal head for dry drilling in firn was used down to $30 \mathrm{~m}$. From this depth, the drill was filled with a $20 \%$ ethanol-water solution. At a depth of $50 \mathrm{~m}$, the temperature in the hole was measured and the concentration of ethanol was corrected accordingly. At a depth of $812 \mathrm{~m}$, the thermal head burned out, and at the same time the electric contact within the winch drive motor was broken. The non-working drill was left at the bottom of the hole for $5-7$ minutes, which was long enough for the drill to become frozen in and stuck. Attempting to pull up on the cable resulted in the cable being separated from the drill, and further drilling ceased. The drilling operation consisted of three men working one shift. They achieved a 14.3-m/day (100-m/week) average ice core production rate. The mean core length was close to $2 \mathrm{~m}$, and the core diameters varied from 78 to $81 \mathrm{~mm}$ (Morev and Raikovsky 1979; Kislov et al. 1983; Morev et al. 1989).

\section{7-78, Twenty-third SAE}

\section{Vostok-1}

The hole drilled during the $21^{\text {st }}$ and $22^{\text {nd }}$ SAE was continued with a TELGA-14M drill from 304 to $430 \mathrm{~m}$ in 15 days or $8.4 \mathrm{~m} /$ day (Kudryashov et al. 1991).

\section{Base Salut $\left(65^{\circ} 32^{\prime} \mathrm{S}, 96^{\circ} 30^{\prime} \mathrm{E}\right)$}

Base Salut operated from 1 February to 27 April 1978 in the central part of the Shackleton Shelf Glacier, $50 \mathrm{~km}$ to the south of its edge (Savatyugin and Preobrazhenskaya 2000). An AFTD (ETB-3 thermal drill) core drilled $195.7 \mathrm{~m}$, including $65 \mathrm{~m}$ of firn, from 11 March to 21 April 1978 and reached the sea (Savatyugin 1980). Morev et al. (1989) reported the final depth of $202 \mathrm{~m}$. The drilling down to $43.5 \mathrm{~m}$ was carried out using a special firn thermal head. This interval was then cased with aluminum tubing (inner diameter $115 \mathrm{~mm}$ ), and the drilling was continued with an ETB-3 
drill using an ethanol-water solution. The drill head power was reported as $1.2 \mathrm{~kW}$, which must have been in the firn. The maximum core length was $2.05 \mathrm{~m}$. The rate of penetration varied from 3.5 to $4 \mathrm{~m} / \mathrm{h}$. The mean ice core production rate was $4.9 \mathrm{~m} /$ day.

\section{8-79, Twenty-fourth SAE}

\section{Mirny}

During the winter, a temporary base, Gornaya $\left(67^{\circ} 12^{\prime} \mathrm{S} ; 93^{\circ} 17^{\prime} \mathrm{E}\right)$, at the $73-\mathrm{km}$ mark of the Mirny-Vostok route was established. The base consisted of three tractors with drilling and dwelling shelters. The new mobile PBU-2 drilling shelter measured $3.5 \times 9 \mathrm{~m}$, had an A-shaped mast $8 \mathrm{~m}$ high, and was built for autonomous operations outside of the Antarctic permanent stations.

A dry hole was drilled down to $430.3 \mathrm{~m}$ using a TELGA-14M thermal drill, with a mean penetration rate of $1.55 \mathrm{~m} / \mathrm{h}$. Then the hole was filled with aircraft fuel (TS-1) and the drilling was continued with a TBZS-152M thermal drill. When the hole reached $721 \mathrm{~m}$, the drill head was changed. The outer diameter of the new head was $0.7 \mathrm{~mm}$ larger than the old one. During the enlarging or reaming process, a new off-set hole was accidentally started at the depth of $500 \mathrm{~m}$. After the deviation, the new hole was drilled to $750 \mathrm{~m}$. The rate of penetration of the TBZS- $152 \mathrm{M}$ drill was $1.75 \mathrm{~m} / \mathrm{h}$, the mean length of core was $1.9 \mathrm{~m}$, and the power of the drill head was $2.5 \mathrm{~kW}$ (Bobin et al. 1986; Kudryashov et al. 1991).

\section{Pionerskaya $\left(69^{\circ} 44^{\prime}\right.$ S, $95^{\circ} 30^{\prime}$ E, 375-km mark on the Mirny-Vostok route)}

Pionerskaya operated as an all-winter station from 27 March 1956 to 15 January 1959 (Savatyugin and Preobrazhenskaya 1999). Then it was used as a temporary base on the Mirny-Vostok route. A traverse to Pionerskaya was conducted during the summer season, bringing a TELGA-14M drill (Kudryashov et al. 1991). A 137.5-m hole was drilled in 14 days in February 1979. The drill building was left in place for the next season.

\section{Ross Ice Shelf (J-9 Camp)}

From 1-13 December 1978, an AFTD of the ETB-3 type core drilled $416 \mathrm{~m}$ through the ice shelf. It included $50 \mathrm{~m}$ of firn. Funding for the drilling project was provided by the National Science Foundation (USA). The concentration of ethanol steadily decreased from $75 \%$ at the top to $40 \%$ at a depth 
of $400 \mathrm{~m}$. The mean length of run was near $2.5 \mathrm{~m}$. The penetration rate varied from $3.5^{-4.6} \mathrm{~m} / \mathrm{h}$. A total of about $2000 \mathrm{~L}$ of ethanol was needed to drill completely through the ice shelf (Zotikov 1979; Zotikov et al. 1981; Morev et al. 1989).

\section{9-80, Twenty-fifth SAE}

\section{Vostok}

The PBU-2 mobile drilling shelter utilized for drilling at base Gornaya was towed to Vostok and used for drilling of a new deep hole at Vostok Station. The first $112 \mathrm{~m}$ of the new Hole (3G) (the letter $\mathrm{G}$ is the first letter of the Russian word "glubokaya"-“deep") was drilled as an uncased, dry hole using a TELGA-14M thermal drill. Tests had revealed that the use of steel casing contaminated the hole with oxidation products, so no casing was used in the approximately $100 \mathrm{~m}$ of firn. Below the firn-ice transition from a depth of $112 \mathrm{~m}$, the TBZS-152M thermal drill was used in a fluidfilled hole consisting of TS- 1 aviation fuel plus CFC11. The hole was extended to $1351 \mathrm{~m}$ by 17 December 1980 and to $1415 \mathrm{~m}$ by the end of the season (Kudryashov et al. 1983, 1983a,b; Kudryashov et al. 1984; Kudryashov 1989; Kudryashov et al. 1984a,b; Kudryashov et al. 1991).

During the summer season (December 1979-February 1980) the microbiological hole MB-1 drilled during the $20^{\text {th }}$ and $22^{\text {nd }}$ SAE was deepened to $320 \mathrm{~m}$ using a TELGA-14M thermal drill (Savatyugin and Preobrazhenskaya 2000).

\section{Mirny}

On 9 May 1980, a temporary base Pobeda, was established at the $43-\mathrm{km}$ mark of the Mirny-Vostok route. The main purpose of the drilling operation was to test a new version of an AFTD, named ETB-5 (Fig. 9). The special mobile drilling building was built utilizing the winch and mast from the drilling operations at base Salut (Fig. 10). From 13 May to 27 June, the hole was drilled down to $387 \mathrm{~m}$, with an ice core production rate of 8.8 $\mathrm{m} /$ day (Kudryashov et al. 1983b; Savatyugin and Preobrazhenskaya 2000). Morev et al. (1990) reported the drilling of a 220-m hole; Zagorodnov et al. (1998) reported the drilling of a 320-m hole. On 3 July the base Pobeda was closed and the drilling staff returned to Mirny. 


\section{Pionerskaya}

The traverse from Mirny-Pionerskaya-Mirny was carried out from 17 January to 14 March 1980 (Savatyugin and Preobrazhenskaya 2000). Another hole, 375-m deep, was drilled during 21 days with an ice core production rate of $8.8 \mathrm{~m}$ /day at Pionerskaya with a TELGA-14M drill (Smirnov 1983; Kudryashov et al. 1991).

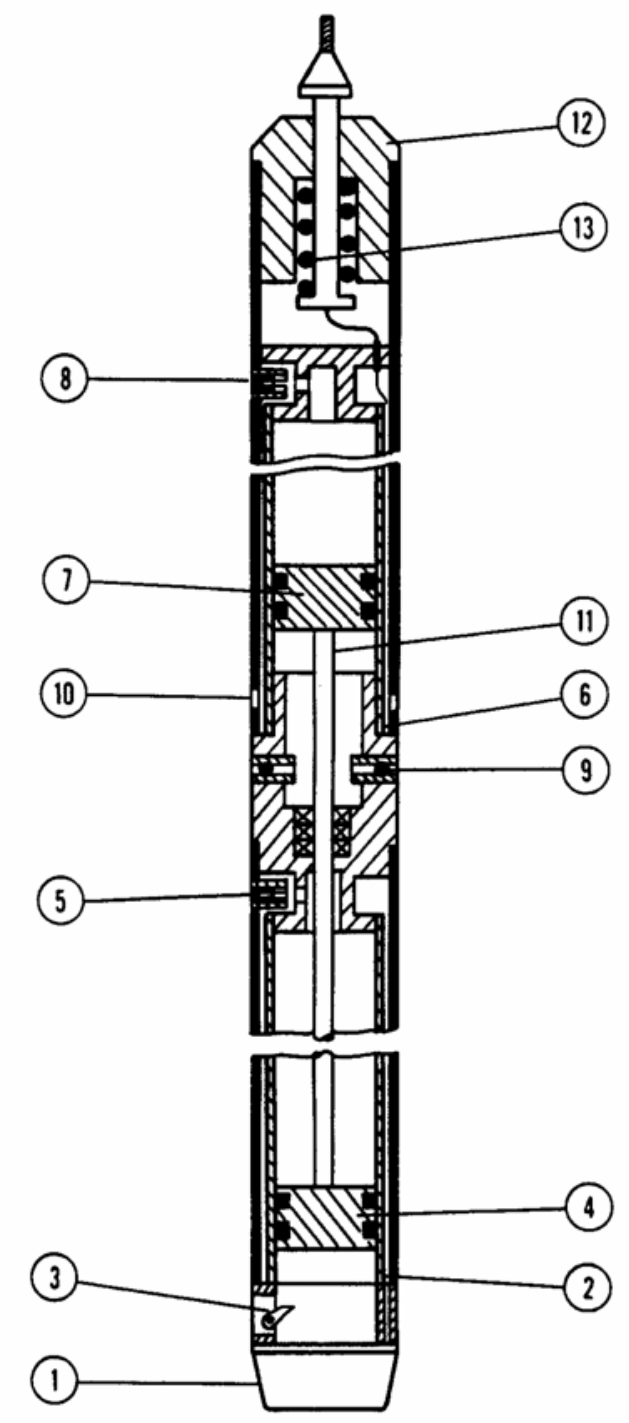

Figure 9. Schematic diagram of the ETB-5 electro-thermal core drill. (1) heater shoe, (2) lower double tubes, (3) core grippers, (4) piston with rings, (5) lower fluid filling inlets, (6) upper double tubes, (7) upper piston with rings, (8) upper fluid filling inlets, (9) inlet pressure valves, (10) fluid discharge openings, (11) connecting rod, (12) end cap assembly, (13) spring and cable termination assembly (from Bogorodsky et al. 1984). 


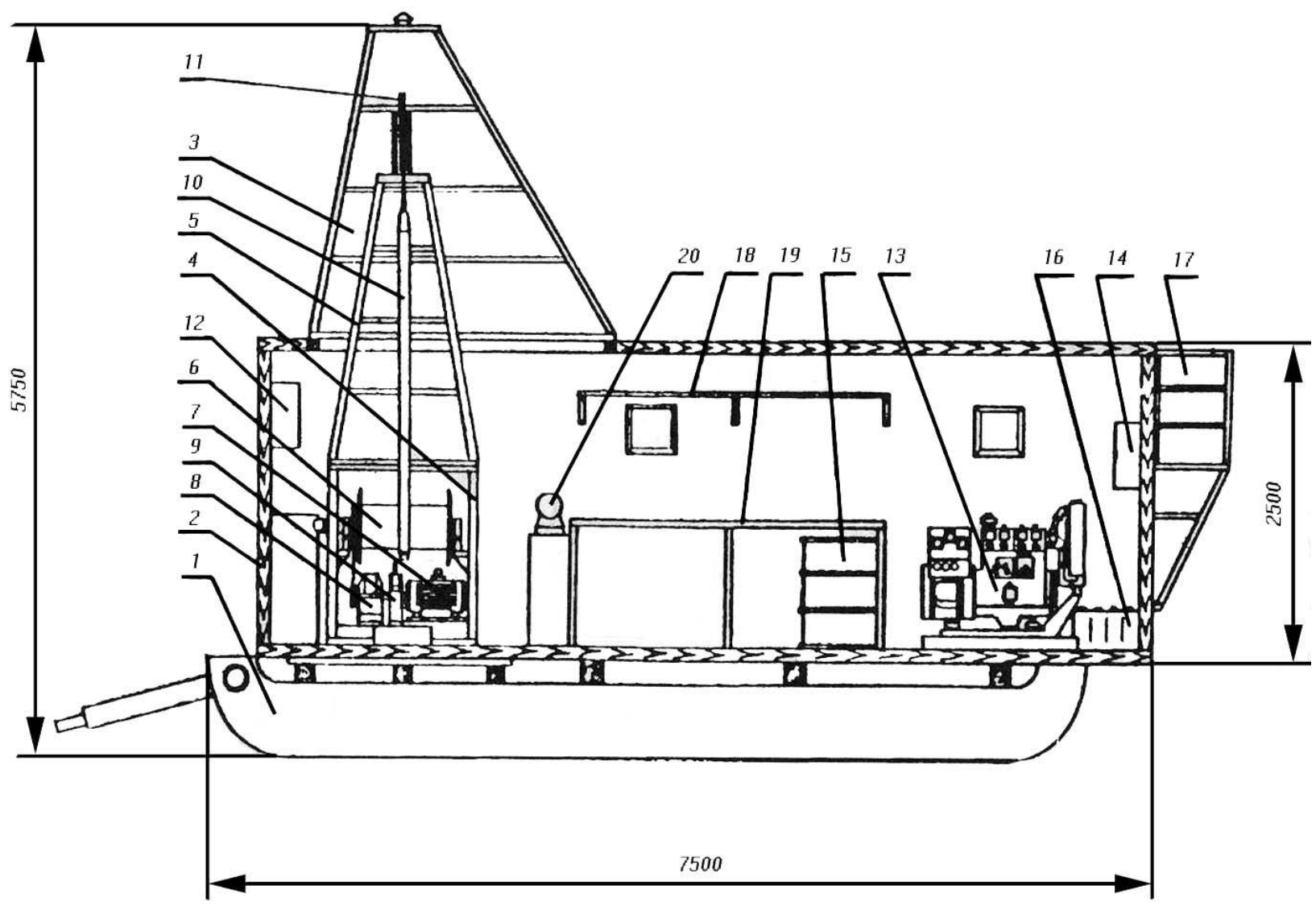

Figure 10. Schematic of drilling complex at Pobeda base (25 th SAE). (1) sledge, (2) building walls, (3) frame, (4) winch frame, (5) mast, (6) winch, (7) MT-111-6 electric motor, (8) RTsD-250 gear reducer, (9) electric brake, (10) drill, (11) wheel, (12) electrical desk, (13) 2E-16A diesel-generator, (14) main electrical desk, (15) barrel, (16) STK-140 accumulators, (17) barrels with drilling fluid, (18) shelving, (19) workbench, (20) grinding lathe (from Savatyugin and Preobrazhenskaya 2000).

\section{0-81, Twenty-sixth SAE}

\section{Vostok}

The drilling of Hole $(3 \mathrm{G})$ hole was continued with a TBZS-152M drill in the interval from 1415-1500 m. Beyond this depth, the TBS-112VCh thermal coring drill (Fig. 3c, Table 1) was used. TBS-112VCh is the Russian abbreviation for "thermal drill with a high frequency supply," and the number 112 is the outer diameter of the drill head. The drill head OD/ID dimensions were $112 / 92 \mathrm{~mm}$, the drill length was $9 \mathrm{~m}$, and it weighed $180 \mathrm{~kg}$. This drill used a high frequency power supply $2500 \mathrm{~Hz}$ of which reduced the size of the downhole transformer. The voltage at the surface was 800$1000 \mathrm{~V}$, which dropped to $700-900 \mathrm{~V}$ at the drill, where it was reduced to 20 to $25 \mathrm{~V}$ for operating the drill. The water tank wasn't heated. The melt water was collected in a tank and frozen inside. At the surface the tank was 
removed and replaced by an empty one. The core barrel was made from a thick-walled tube, with the water suction tubes and the electrical lines hidden within the wall.

The drilling rate was doubled to $3.5-4 \mathrm{~m} / \mathrm{hr}$ over the TBZS-152M with 5 $\mathrm{kW}$ of power (Kudryashov et al. 1984a). After reaching a depth of $1580 \mathrm{~m}$, owing to problems with the melt water removal system, the drill became stuck near the bottom of the hole. A new off-set hole was started by another TBS-112VCh thermal drill with a length of $7.1 \mathrm{~m}$ at a depth of 1500 $\mathrm{m}$, and in the interval of $1550-1560 \mathrm{~m}$, a full diameter core was recovered (Zagrivny and Moiseev 1988; Savatyugin 2001). The new off-set hole was named Hole (3G-1). A depth of $1810 \mathrm{~m}$ was reached by 8 January 1982 and $2004 \mathrm{~m}$ was reached by the end of the season (Kudryashov et al. 1983a, 1984, 1991; Zagrivny et al. 1985; Savatyugin and Preobrazhenskaya 2000).

\section{Komsomolskaya Station ( $\mathbf{7 4}^{\circ} 06^{\prime}$ S; $94^{\circ} 30^{\prime}$ E, $870 \mathrm{~km}$ south of Mirny)}

Komsomolskaya Station_operated as an all-winter station from 6 November 1957 to 9 March 1959 (Savatyugin and Preobrazhenskaya 1999). Then it was used as a temporary base on the Mirny-Vostok route. In early 1981 a drilling site was established and a drilling operation started using an AFTD ETB-5. The drilling wasn't very successful and at $73 \mathrm{~m}$, the drill (assumed to be the ETB-5) became stuck and was lost (Kudryashov et al. 1983b).

\section{Mirny}

During March-October 1981, testing of the AFTD ETB-5 drill continued and a new drill for dry holes, ETB-140, was also tested. Five holes from 16 to $36 \mathrm{~m}$ were drilled near the runway at Mirny (Dyurgerov et al. 1987; Savatyugin and Preobrazhenskaya 2000).

\section{Traverse Mirny-Pionerskaya-Dome C}

The traverse took place from 19 January to 19 March 1981. At the 1045-km mark on the Mirny-Pionerskaya-Dome C route, a 306-m hole was drilled with a TELGA-14M. Drilling took 14 days, with a mean ice core production rate of $21.9 \mathrm{~m} /$ day. On the way back on $16 \mathrm{March}$, the drilling shelter was destroyed by fire, and, tragically, one crew member died (Kudryashov et al. 1991; Savatyugin and Preobrazhenskaya 2000). 


\section{1-82, Twenty-seventh SAE}

\section{Vostok}

In early 1982, Hole (3G-1) was advanced to $2083 \mathrm{~m}$ with a TBS-112VCh thermal drill (Zagrivny et al. 1985). A tragic generator-room fire on 12 April 1982 took the life of the chief mechanic and curtailed further drilling (Kudryashov et al. 1991). The construction of a new stationary drilling complex was started for a new Hole (4G). It was built on two steel sleds with a 15-m mast, and $4000 \mathrm{~m}$ of a KG-95-180 type, seven-conductor armored cable (Kudryashov 1989; Kudryashov et al. 1998).

\section{Komsomolskaya Station}

During November 1981 to February 1982, an 800.6-m hole was drilled at Komsomolskaya Station by the AARI drilling group. A thermal drill of the ETB-140 type for dry holes was used for drilling in the snow-firn zone down to $120 \mathrm{~m}$. In this interval, 191 runs were carried out with the following parameters: core length $0.62-0.71 \mathrm{~m}$; core diameter $75-80 \mathrm{~mm}$; power consumption 1.9-2 $\mathrm{kW}$; with the penetration rate decreasing from $2.6 \mathrm{~m} / \mathrm{h}$ in firn to $1.8-2 \mathrm{~m} / \mathrm{h}$ in ice. Additional drilling was continued using an AFTD ETB- 5 with the following mean parameters: core length 0.67 $\mathrm{m}$; core diameter $79 \mathrm{~mm}$; power consumption $2.5 \mathrm{~kW}$; and penetration rate $3.6-3.8 \mathrm{~m} / \mathrm{h}$. In total nearly 1200 runs were carried out by the ETB- 5 drill, with a mean core production of $10 \mathrm{~m} /$ day. Drilling was stopped on 21 February 1982 at a depth of $800.6 \mathrm{~m}$. After finishing the drilling, thermometer and inclinometer measurements were completed. The temperature in the hole increased from $-53.5^{\circ} \mathrm{C}$ at a depth of $5 \mathrm{~m}$ to $-49.8^{\circ} \mathrm{C}$ at $800 \mathrm{~m}$. The hole was then filled with an ethanol-water solution to a depth of $230 \mathrm{~m}$, and the drilling site was secured and prepared for the next summer season (Manevsky et al. 1983; Morev et al. 1989).

\section{2-83, Twenty-eighth SAE}

\section{Vostok}

On 26 December 1982, a fire destroyed the PBU-2 drilling shelter, which housed the drilling complex for Hole $(3 \mathrm{G})$ and drilling was suspended (Savatyugin and Preobrazhenskaya 2000). The construction of a new drilling complex was finished by 29 May 1983 (Fig. 11) and a new Hole (4G) was started on 3 July. The $178-\mathrm{mm}$-diameter hole reached $120 \mathrm{~m}$ with a TELGA-14M thermal drill. After the hole was filled with liquid, a TBZS- 
$152 \mathrm{M}$ thermal drill was used to advance it to $279 \mathrm{~m}$ by the end of the season, 12 February 1984 (Kudryashov et al. 1991).

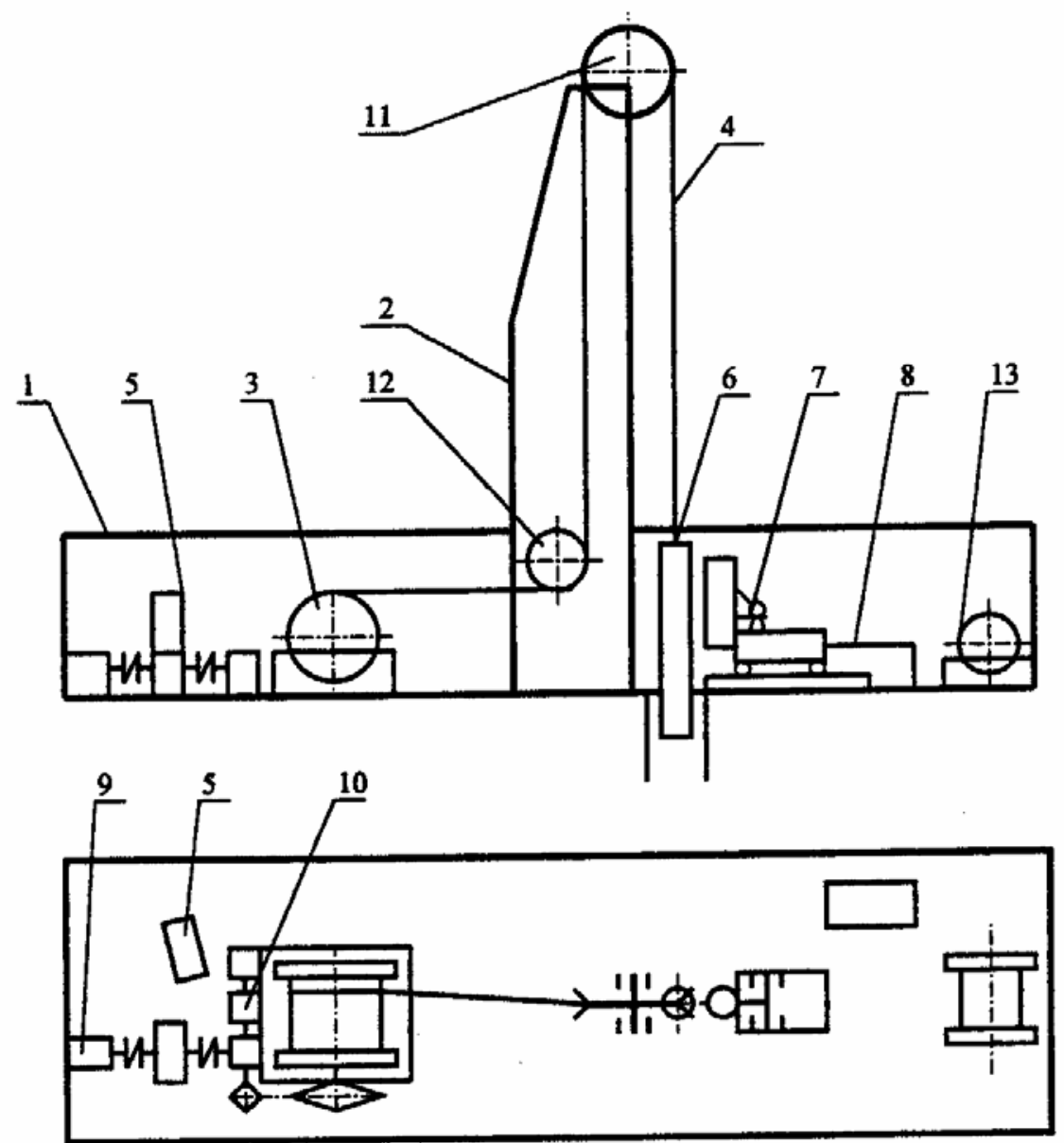

Figure 11. Drilling complex at Vostok Station used for drilling of $4 G$ and $5 G$ holes. (1) drilling building, (2) tower, (3) winch, (4) cable, (5) control desk, (6) drill, (7) drill handling device, (8) DC generator, (9) electric motor, (10) worm reducer, (11) pulley, (12) pulley, (13) geophysical winch (from Kudryashov et al. 2002).

\section{Komsomolskya Station}

The base was reopened on 13 December 1982 during a traverse from Mirny. The main drilling staff arrived at the base by plane on 6 January 1983. The drilling with an AFTD (ETB-5), which was terminated in February 1982, continued after 11 months with no apparent difficulties. It reached $871.5 \mathrm{~m}$ by January 1983 where, because of an electrical failure within the drill, the drill quickly froze to the ice and became stuck. The 16.5-mm cable ruptured near the surface during the recovery attempt and 
an 870-m length of cable was left in the hole at a depth of $110 \mathrm{~m}$ (Kornilov, ed. 1987; Morev et al. 1989).

\section{Base Druzhnaya $\left(7^{\circ} 34^{\prime}\right.$ S; $40^{\circ} 13^{\prime}$ W, Filchner Ice Shelf)}

The seasonal Base Druzhnaya (later when a few bases with the same name appeared it was renamed Druzhnaya-1) was constructed by the seaside of the Filchner Ice Shelf in 1975. During the summer seasons from 1982 to 1985, several holes were drilled by specialists from LMI (Table 5). The drilling was done with a conventional rig of the SKB-4 type, with a MRUGU-18/20 type mast (Fig. 12), and SSK-59 type "wire-line" drilling equipment. The first hole (\#1) was drilled to $172.3 \mathrm{~m}$ with $100 \%$ core recovery. The rotational speed was 155 or $280 \mathrm{rpm}$. The rate of penetration was $60 \mathrm{~m} / \mathrm{h}$. Aviation fuel TS-1 was used as a drilling fluid (the flow rate of the NB-3 pump was $40 \mathrm{~L} / \mathrm{min}$.). The drilling was stopped because of a leak in the protective casing — an intolerable condition in a wire line systemand the subsequent loss of fluid circulation (Kudryashov et al. 1983c 1988; Bychenkov and Egorov 1986; Bobin et al. 1988).

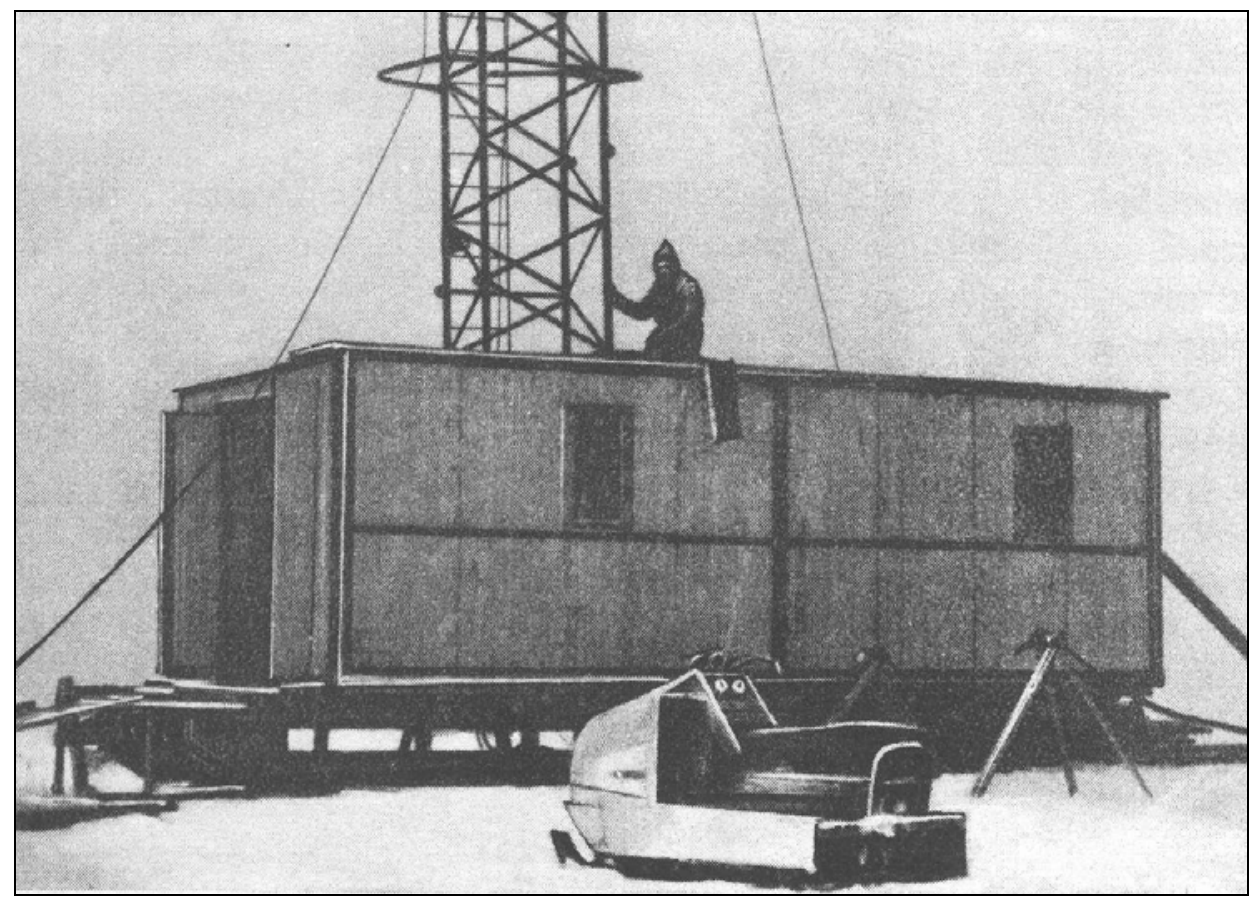

Figure 12. Drilling shelter at Druzhnaya (28 ${ }^{\text {th }} \mathrm{SAE}$ ) (from Kudryashov et al. 1983c). 
Table 5. LMI Drilling At Base Druzhnaya.

\begin{tabular}{|c|c|c|c|c|c|}
\hline $\begin{array}{l}\text { Expedition \# } \\
\text { (Year) }\end{array}$ & Hole \# & $\begin{array}{l}\text { Leader of the } \\
\text { drilling team }\end{array}$ & Depth, m & Type of drill & $\begin{array}{l}\text { Mean speed of } \\
\text { penetration, } m / h\end{array}$ \\
\hline $\begin{array}{l}28 \\
(1982-1983)\end{array}$ & 1 & G.K.Stepanov & $0-172.3$ & SSK-59 & 60 \\
\hline \multirow{2}{*}{$\begin{array}{l}29 \\
(1983-1984)\end{array}$} & \multirow{2}{*}{2} & \multirow{2}{*}{ G.K.Stepanov } & $0-47$ & Three-spiral auger & 15 \\
\hline & & & $47-230$ & SSK-59 & $26-100$ \\
\hline \multirow{2}{*}{$\begin{array}{l}30 \\
(1984-1985)\end{array}$} & \multirow{2}{*}{3} & \multirow{2}{*}{ S.P.Zhigalev } & $0-60$ & Two-spiral auger & 36 \\
\hline & & & $60-310$ & SSK-59 & $53-66$ \\
\hline \multirow{4}{*}{$\begin{array}{l}31 \\
(1985-1986)\end{array}$} & 4 & \multirow{4}{*}{ V.M.Zubkov } & $0-55$ & Two-spiral auger & 55 \\
\hline & 5 & & $0-44.6$ & Two-spiral auger & 50 \\
\hline & \multirow{2}{*}{6} & & $0-40$ & Two-spiral auger & 55 \\
\hline & & & $40-300.5$ & SSK-59 & $40-56$ \\
\hline
\end{tabular}

1983-84, Twenty-ninth SAE

\section{Vostok}

Problems with the winch (the bolts of the winch drive shaft coupling failed) used for Hole $(4 \mathrm{G})$ resulted in the loss of the TBZS-152M drill at the previous season's depth of $279 \mathrm{~m}$ (Kudryashov 1989). Further drilling operations in Hole $(4 \mathrm{G})$ were curtailed.

The mobile drilling complex PBU-3, which was transported from Mirny during the $28^{\text {th }}$ SAE, was installed above the mouth of Hole $(3 \mathrm{G})$, replacing the PBU-2 that had been destroyed by fire. The drilling operations in Hole (3G-1) were resumed with a TBS-112VCh thermal drill, but the lower part of the hole had closed in during the long period of inactivity. During the enlarging or reaming process, a new off-set hole was accidentally started. at a depth of $1968.5 \mathrm{~m}$. It was named Hole (3G-2) and was advanced to 2040 m (Kudryashov et al. 1991).

\section{Base Druzhnaya}

During the summer season a second hole (\#2) was drilled to $230 \mathrm{~m}$ without core recovery. The upper interval down to $47 \mathrm{~m}$ was drilled using a three-spiral coring auger with an OD of $98 \mathrm{~mm}$ and a flight pitch of 135 $\mathrm{mm}$ (Fig. 13). Then the same drilling equipment from the $28^{\text {th }} \mathrm{SAE}$ was used, except for a special drill head used for full-diameter (no core) drill- 
ing. The core was recovered from five intervals only (each interval of length nearly $2 \mathrm{~m}$ ). The rotational speed was 155 or $280 \mathrm{rpm}$. The rate of penetration varied from 26 to $100 \mathrm{~m} / \mathrm{h}$. TS-1 aviation fuel was used as a drilling fluid. The flow rate of the NB-3 pump was $40 \mathrm{~L} / \mathrm{min}$. The drilling was stopped because of a similar problem previously encountered, a leak in the protective casing and the subsequent loss of fluid circulation (Kudryashov et al. 1983c, 1988; Bychenkov and Egorov 1986; Zhigalev and Shkurko 1988; Bobin et al. 1988).

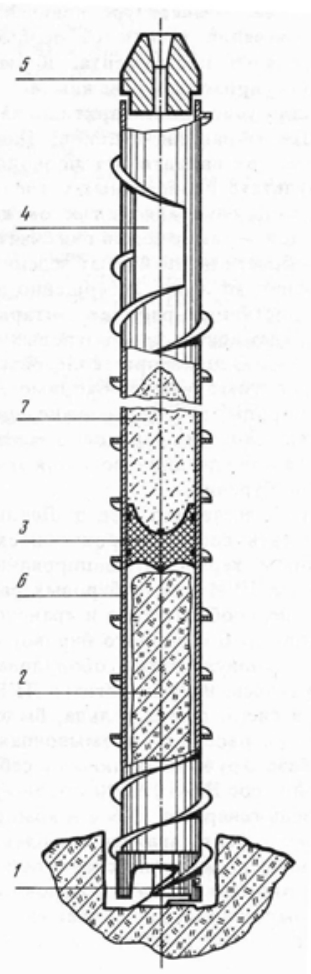

Figure 13. Core auger used at Druznaya Station for drilling in firn. (1) drill head, (2) core, (3) moveable barrier, (4) window, (5) cable termination, (6) auger, (7) ice chips (from Kudryashov et al. 1988).

\section{4-85, Thirtieth SAE}

\section{Vostok}

Drilling in Hole (3G-2) was resumed. A TBS-112VCh thermal drill reached 2201.7 $\mathrm{m}$ in August 1985 for a new ice core drilling depth record (Kudryashov 1989).

The lost drill in Hole (4G) was bypassed with an offset Hole (4G-1) started at $120 \mathrm{~m}$ by a TELGA-14M thermal drill and was continued to a depth of 
$167 \mathrm{~m}$ and then to $692 \mathrm{~m}$ with a TBZS-152M thermal drill (Kudryashov et al. 1991).

\section{Base Druzhnaya}

A third hole (\#3) was drilled down to $310 \mathrm{~m}$ in February 1985. The upper interval down to $63 \mathrm{~m}$ was drilled using a two-spiral coring auger with an OD of $98 \mathrm{~mm}$ and reduced flight pitch of $80 \mathrm{~mm}$. The casing was fabricated from steel tubing with an OD of $89 \mathrm{~mm}$ and sealed the upper snowfirn interval. The lower part of the casing was immersed in hot water pumped directly to the bottom. After freezing, the new bottom rose to 33.4 $\mathrm{m}$. Then the wire-line drilling equipment of type SSK-59 was used with special drill heads for full-diameter drilling. The outer diameter of the drill heads was $64 \mathrm{~mm}$. The rotational speed was $280 \mathrm{rpm}$. The rate of penetration varied from 53 to $66 \mathrm{~m} / \mathrm{h}$. The cuttings were removed by the circulation of compressed air produced by a $2 \mathrm{VU}-1-2,2 / 13$ compressor with a pressure of $0.25-0.45 \mathrm{MPa}$. At $310 \mathrm{~m}$ the drill reached sub-glacial water and salt water entered the hole. During hoisting, the drill was stuck near 160 m (Kudryashov et al. 1983c, 1988; Bychenkov and Egorov 1986; Zhigalev and Shkurko 1988; Bobin et al. 1988).

While drilling, hole (\#3) temperature measurements were taken (Dyurgerov et al. 1988). In the upper part of the hole temperatures decreased from $-24.6 /-24.8^{\circ} \mathrm{C}$ at the boundary of the active layer to $-25.4^{\circ} \mathrm{C}$ at 160 $\mathrm{m}$. In the interval from $160-200 \mathrm{~m}$, hole temperatures remained nearly constant. Deeper temperatures rapidly increased, reaching the pressure melting point at the bottom. Even at a depth of $280 \mathrm{~m}$, the temperature was still very low at $-17 \cdot 7^{\circ} \mathrm{C}$.

\section{Dome B $\left(77^{\circ} 04^{\prime} \mathrm{S}, 95^{\circ} 55^{\prime} \mathrm{E}\right.$, elevation $\left.3850 \mathrm{~m}\right)$}

From 23 January to 22 March 1985, a Mirny-Dome B traverse was completed to establish a seasonal drilling base. The drilling equipment and fuel were transported to the site, and a $5^{-} \times 3^{-} \times 2$-m core storage shelter was constructed (Savatyugin and Preobrazhenskaya 2000).

\section{5-86, Thirty-first SAE}

\section{Vostok}

The TBS-112VCh thermal drill was stuck in Hole (3G-2) during enlarging operations in the interval of 1935-1943 m from the previously attained 
depth of 2202 m (Kudryashov et al. 1991). Further activity in Hole (3G-2) was stopped.

Hole (4G-1) was advanced to $752 \mathrm{~m}$ with the TBZS-152M thermal drill. The old Hole (4G) was accidentally reopened owing to a faulty ice plug installed during SAE 30. This made it impossible to return to Hole (4G-1), so a new offset hole was started from Hole (4G) at $159 \mathrm{~m}$ and called (4G-2). A depth of 779 m was reached by 26 December 1986 (Kudryashov et al. 1991; Savatyugin 2001). Owing to inadequately centering of the drill, the inclination of Hole (4G-2) reached $18^{\circ}$ in the interval of 500-600 m. To reduce the inclination, a shortened version of the TBZS-152M thermal drill was used (Kudryashov 1989).

\section{Dome B}

From 25 January to 1 March, drilling with an ETB-140 and an ETB-130 thermal drill for dry holes was carried out. On 1 March, at a depth of $92 \mathrm{~m}$, the dwelling facilities and power station were closed down temporarily (Savatyugin 2001).

\section{Base Druzhnaya}

During the summer season three bore holes \#4, \#5, and \#6 were drilled: 55.5, 44.6 and 300.5 $\mathrm{m}$ deep, respectively Drilling of the first two holes was stopped because of sticking of the two-spiral coring augers (V.M. Zubkov, personal communication, 2004). The third hole was drilled to $40 \mathrm{~m}$, also with a coring auger. The mean length of run was $0.5 \mathrm{~m}$ and the mean rate of penetration was $36 \mathrm{~m} / \mathrm{h}$ (Zhigalev and Shkurko 1988). Then drilling was continued with a SSK-59 type wire-line drill with an air chip removal system. At a depth of $280 \mathrm{~m}, 3 \mathrm{~m}^{3}$ of a special emulsion $(\approx 60 \%$ diesel fuel of arctic blend, plus $\approx \mathrm{a} 40 \%$ water solution of $\mathrm{CaCl}_{2}$ plus, and a small amount of stabilizer) was dumped into the hole. The drilling was continued with shortened runs using bottom circulation of the drilling fluid. At $300.5 \mathrm{~m}$ the hole reached sub-glacial water. The drill was hoisted to the surface without any complications (Bobin et al. 1988).

\section{6-87, Thirty-second SAE}

\section{Vostok}

Drilling in Hole (4G-2) continued with a TBZS-152M drill to $1502 \mathrm{~m}$ (Kudryashov et al. 1991). 


\section{Base Druzhnaya}

In May 1986 the edge of the Filchner Ice Shelf with an area of over 13,000 $\mathrm{km}^{2}(60-80 \times 230 \mathrm{~km})$ broke off and was carried away in the form of three huge icebergs. Base Druzhnaya was located on one of these icebergs, and in January 1987 the Captain Kondrat'ev found the new position of the base. From 30 January to 9 February, the main facilities of the base were loaded aboard the ship and the base was closed (Savatyugin and Preobrazhenskaya 2000).

\section{7-88, Thirty-third SAE}

\section{Vostok}

The continuation of drilling in Hole (4G-2) with the TBZS-152M drill reached 2213 m by 1 November 1988, which exceeded the old record, eventually reaching $2383 \mathrm{~m}$ by the end of the season. The hole inclination did not exceed $4^{\circ}$ (Kudryashov 1989; Savatyugin 2001). Figure 14 shows the array of drilling structures visible at Vostok.

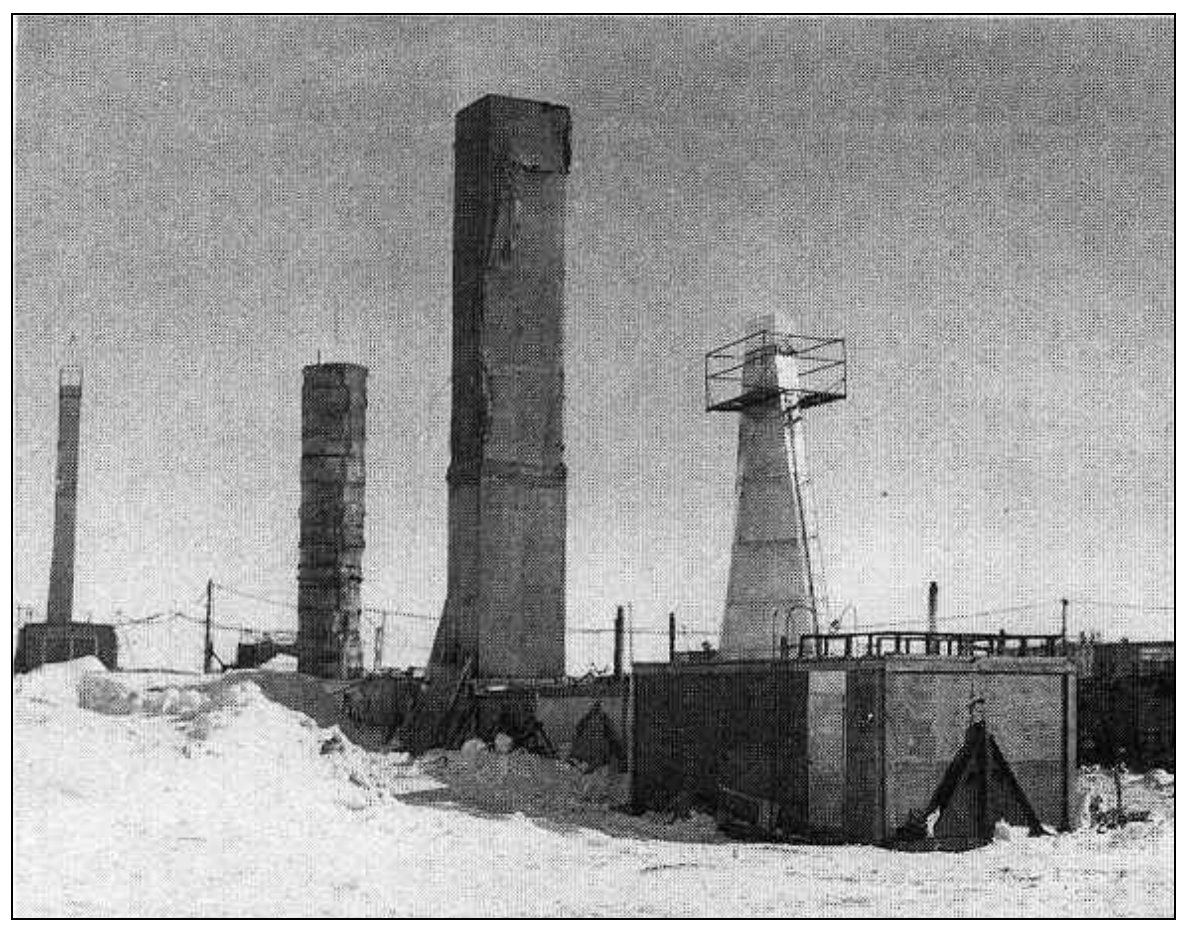

Figure 14. Drilling structures visible at Vostok (33 $\left.3^{\text {rd }} \mathrm{SAE}\right)$. 


\section{Mirny}

A traverse to the 105-km mark on the Mirny-Vostok route was conducted from 15 January to 2 April 1988. The upper $527 \mathrm{~m}$ of a hole was drilled with a TELGA-14M drill. Then the hole was filled with a kerosene type (TS-1) aircraft fuel and drilling was continued with a TBZS-152 drill to a depth of $740 \mathrm{~m}$. The drilling operations were finished on 23 March 1988 at 740 m (Kudryashov et al. 1991; Savatyugin 2001).

\section{Dome B}

Another traverse was done on the route Mirny-Komsomolskaya-Dome B-Mirny. The temporary base Dome B was opened and a borehole from the surface down to $780 \mathrm{~m}$ was drilled using an ETB-130 thermal drill for dry holes. The drilling was finished on 11 February 1988. The hole was then filled with an ethanol anti-freeze solution to $120-\mathrm{m}$ which was below the ice-firn transition depth. The minimum borehole temperature was $-58^{\circ} \mathrm{C}$. Temperature measurements in the 92-m hole drilled during the $31^{\text {st }} \mathrm{SAE}$ were also taken (Morev et al. 1989; Savatyugin 2001).

\section{Base Druzhnaya-4 (6944' S; 7242’ E; Oasis near Emery Ice Shelf)}

Druzhnaya-4 was established as a temporary summer station in January 1987 and closed in April 1995 (Savatyugin 2001). During 1987-1989 specialists of the IGAS Institute of Geography of Russian Academy of Sciences carried out glaciological investigations in the region, including the drilling of a 252-m hole using an ATED ETB-3 drill. The measured temperature at $75 \mathrm{~m}$ was $-16.3^{\circ} \mathrm{C}$. The thickness of the firn zone was nearly $40 \mathrm{~m}$ (Raikovsky et al. 1990).

\section{8-89, Thirty-fourth SAE}

\section{Vostok}

Deep drilling of Hole (4G-2) by the TBZS-152M thermal drill was stopped at $2428.5 \mathrm{~m}$ in April 1989 owing to hole closure caused by a deficiency in fluid pressurization. Attempts to increase the density of the hole fluid with a high density additive were not fully successful.

In June 1989, drilling resumed with an electro-mechanical drill interchangeably referred to as KEMS-112 or KEMS-132 (Fig. 15, Table 6), which represented the second and third attempts at designing an electro- 
mechanical drill. The first design, KEMS-152, had been planned for the $16^{\text {th }}$ SAE but was never used. The next version was lighter and simpler and was called KEMS-112. It was designed under the leadership of N.I. Vasiliev at the LMI in the early 80 . The next redesign was referred to as KEMS132 or also as KEMS-135. The drive motor for either design was 3-phase, $220 \mathrm{~V}$, with a power rating of $2.2 \mathrm{~kW}$. A two stage gear reducer lowered the speed from $2800 \mathrm{rpm}$ to $230 \mathrm{rpm}$. Testing had been conducted in the Arctic prior to the drilling at Vostok.

Table 6. Main characteristics of electro-mechanical drills.

\begin{tabular}{|l|l|l|l|l|l|l|}
\hline Type & $\begin{array}{l}\text { Cutter outer } \\
\text { diameter } \\
(\mathrm{mm})\end{array}$ & $\begin{array}{l}\text { Cutter inner } \\
\text { diameter } \\
(\mathrm{mm})\end{array}$ & $\begin{array}{l}\text { Core barrel } \\
\text { OD/ID }(\mathrm{mm})\end{array}$ & $\begin{array}{l}\text { Core barrel } \\
\text { length }(\mathrm{m})\end{array}$ & $\begin{array}{l}\text { Overall } \\
\text { length }(\mathrm{m})\end{array}$ & $\begin{array}{l}\text { Weight } \\
(\mathrm{kg})\end{array}$ \\
\hline KEMS-112 & $112-116$ & $85-89$ & $108 / 99$ & $1.5-3$ & 7.5 & 120 \\
\hline $\begin{array}{l}\text { KEMS-132 } \\
\text { KEMS-135 }\end{array}$ & $\begin{array}{l}132-135 \\
137-139\end{array}$ & $106-107$ & $127 / 117$ & $1.5-3$ & $7-12$ & $180-240$ \\
\hline
\end{tabular}

In the first 20 runs the length per run was less than $0.1 \mathrm{~m}$. The drill was stuck at 2431.7 and $2437.5 \mathrm{~m}$, but freed in 5 days and 2 hours, respectively. After every $10-15 \mathrm{~m}$, the hole was enlarged with a 135 - $\mathrm{mm}$ cutting head. At a depth of $2546.4 \mathrm{~m}$, drilling was interrupted for 16 days and a new 4000$\mathrm{m}$ long cable was installed. The drill became stuck on the first run, $1 \mathrm{~m}$ above the bottom. The operation was left for a year with tension on the cable (Kudryashov et al. 1994; Vasil'yev et. al. 1993; Talalay, personal recollections).

\section{Mirny}

In accordance with the International Antarctic Glaciological Project (IAGP) 1989, a traverse on the Mirny-Pionerskaya-Mirny route was conducted from 31 January to 29 March (Savatyugin 2001). Along the way three holes were drilled with a TELGA-14M drill (Kudryashov et al. 1991):

- $\quad 60 \mathrm{~km}$ from Mirny, a 150.5-m hole in 10 days.

- $\quad 140 \mathrm{~km}$ from Mirny, a 150-m hole in 8 days.

- $\quad 200 \mathrm{~km}$ from Mirny, a 150.8-m hole in 11 days. 


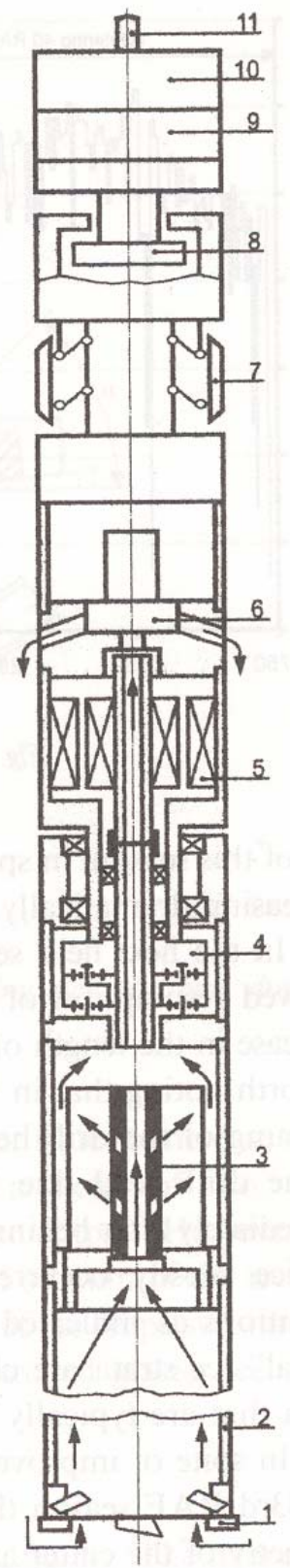

Figure 15. KEMS-132 electro-mechanical drill. (1) drill head, (2) core barrel, (3) chip chamber including chip filter, (4) reducer, (5) electric drive motor, (6) pump, (7) anti-torque system, (8) hammer block, (9) electric chamber, (10) cable suspension clip, (11) cable (from Kudryashov et al. 2002).

\section{9-90, Thirty-fifth SAE}

\section{Vostok}

The drill in Hole (4G) was still stuck. During a recovery attempt, the cable failed near the surface in November 1990 (Kudryashov et al. 1994). After the drilling complex was moved $25 \mathrm{~m}$ to the west in January 1990, a new 
Hole (5G) was started on 20 February 1990, using a TELGA-14M thermal drill to a depth of $120 \mathrm{~m}$ in 62 runs. Beyond this depth, another thermal drill, TBZS-152M, was used. A depth of $1279.8 \mathrm{~m}$ was achieved in 398 runs with the TBZS-152M drill by the end of the season, 29 January 1991 (Tchistiakov et al. 1994; Kudryashov et al., 1998a,b, 2002; Savatyugin, 2001). Figure 16 shows the drilling shelter as it appeared in SAE-35.

During the summer season, two shallow holes BH-1 and BH-2 down to 178 and $138 \mathrm{~m}$ were also drilled at Vostok using a TELGA-14M drill (Kudryashov et al. 1991).

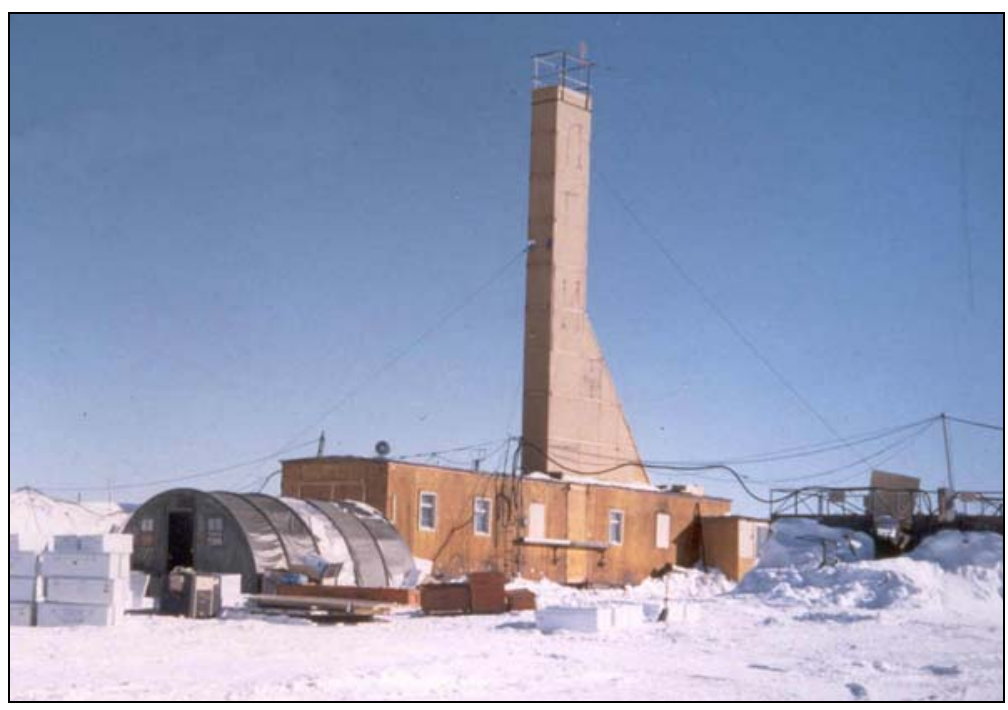

Figure 16. Drilling shelter above hole (5G) constructed during the 27 th and 28th SAE (photograph by P.G.Talalay, $35^{\text {th }}$ SAE).

\section{Mirny}

From 19 January to 18 March 1990, a traverse on the Mirny-PionerskayaVostok-1-Mirny route was conducted (Savatyugin 2001). Along the way three holes were drilled with a TELGA-14M drill (Kudryashov et al. 1991):

- $260 \mathrm{~km}$ from Mirny, a 150-m hole in 7 days.

- $325 \mathrm{~km}$ from Mirny, a 150-m hole in 7 days.

- $400 \mathrm{~km}$ from Mirny, a 150-m hole in 7 days.

\section{0-91, Thirty-sixth SAE: Vostok}

Drilling in Hole (5G) reached $2502.7 \mathrm{~m}$ in December 1991, with the TBZS$152 \mathrm{M}$ thermal drill completing 408 runs. The round trip time to the bottom of the hole and back increased until it consumed 2.6 and 1.8 hours re- 
spectively at the $2500-\mathrm{m}$ depth. The inclination varied from $0.2-0.6^{\circ}$ at $2000 \mathrm{~m}$ and increased gradually from 0.4 to $1.8^{\circ}$ at $2250 \mathrm{~m}$. At the end of December, the drill became stuck during a trip up hole at $2259 \mathrm{~m}$. The problem was caused by hole closure from insufficient fluid pressurization. All attempts at recovery failed and the cable was pulled out of the top of the drill (Tchistiakov et al. 1994; Dmitriev et al. 1995; Kudryashov et al. 1998a,b, 2002).

\section{1-92, Thirty-seventh RAE*}

\section{Vostok}

Densifier (HCFC F-141b) was added to Hole (5G), which increased the fluid density to $900 \mathrm{~kg} / \mathrm{m}^{3}$. About $35 \mathrm{~m}$ of artificial core was dropped on top of the stuck drill, creating a new hole bottom at $2232 \mathrm{~m}$. A shortened version of the TBZS-132 thermal drill, with a length of $6 \mathrm{~m}$, was used to drill a new offset Hole (5G-1). From the depth of $2249.5 \mathrm{~m}$, drilling was continued with a normal TBZS-132 drill with a normal length of $8 \mathrm{~m}$, to a depth of $2270.7 \mathrm{~m}$ by the end of the winter and to $2341.8 \mathrm{~m}$ by the end of the season. The main difference between the TBZS-132 and TBZS-152 thermal drills was the outer diameter of the drill head and the tubing used for the core barrel and water tank (Kudryashov et al. 1998a,b; Savatyugin 2001).

\section{Dome B}

From 8 January to 2 March 1992, a traverse on the route MirnyKomsomolskaya-Dome B-Mirny was conducted. The main purpose of the traverse was to study the behavior of the 780-m holed drilled 4 years earlier at Dome B and to carry out temperature and inclinometer measurements (Savatyugin 2001).

\section{2-93, Thirty-eighth RAE: Vostok}

Hole (5G-1) reached a depth of $2755.3 \mathrm{~m}$ with the TBZS-132 drill. The depth was a new record for thermal drilling in ice. From 18 September 1993, drilling ceased because the supply of drilling fluid was exhausted. From August 1993, ice coring and core research at Vostok Station was conducted by a joint Russian-French-USA project. The Russians maintained the station and conducted the drilling operations, the French pro-

\footnotetext{
* Expeditions are now referred to as Russian Antarctic Expeditions.
} 
vided the technical equipment, and the USA provided the logistical support. Since that time, the core was divided into three equal parts between treaty members (Kudryashov et al., 1998a,b, 2000, 2002).

\section{3-94, Thirty-ninth RAE: Vostok}

During the summer season, the upper part of Hole (5G-1) was enlarged from 180 to $220 \mathrm{~mm}$ using an electro-mechanical reaming technique. The hole was cased with fiberglass tubing and, using a thermal device at the bottom of the casing, it was sealed at a depth of $120 \mathrm{~m}$ so that hole fluid could be retained throughout the permeable zone. The OD/ID of the casing tubes was $179 / 165 \mathrm{~mm}$. The outer diameter of the connecting couplings of the $6 \mathrm{~m}$ long sections was $215 \mathrm{~mm}$. It was discovered, however, that fluid could only be maintained at a depth of 66-104 $\mathrm{m}$ from the surface owing to a leak at an uncertain location (Kudryashov et al. 2000, 2002). On the 10 February 1994, Vostok station was temporarily closed for the winter for logistical and economic reasons (Kudryashov et al. 1998b; Savatyugin 2001).

\section{4-95, Fortieth RAE: Vostok}

On 22 November 1994, the traverse from Mirny reached Vostok and on 27 November the station was fully reopened (Savatyugin 2001). Drilling operations in Hole (5G-1) were resumed. First, to compensate for the ice overburden pressure, the density of the drilling fluid in the hole was increased. Then, the hole was enlarged between 2200 and $2755 \mathrm{~m}$ from 134 to $139 \mathrm{~mm}$ in diameter with an electro-mechanical reamer to facilitate lowering and raising the drill. Drilling began with the KEMS-132 electromechanical drill in February 1995 and reached 3109 m in September 1995, when the drilling was stopped because all of the densifier supply had been consumed. An average drilling run of $2.8 \mathrm{~m}$ was achieved, but beyond $2930 \mathrm{~m}$, the length of the drilling runs decreased dramatically because of sticking and jamming of the drill (Kudryashov et al. 1998,b, 2000, 2002).

\section{5-96, Forty-first RAE: Vostok}

A traverse consisting of 16 vehicles started from Mirny to Vostok on 12 November 1995 but considerable mechanical problems with the vehicles, forced a decision to cancel the traverse at the $645-\mathrm{km}$ mark and return to Mirny. For the first time in Soviet and Russian Antarctic expeditions, a traverse failed to reach Vostok Station. A later traverse succeeded. On 24 
January 1996, Vostok Station was closed down again (Savatyugin 2001). Future drilling operations would be reduced to short Antarctic seasons.

A supply of the densifier (HCFC F-141b) was delivered to the station by C130 aircraft from U.S. McMurdo Station, and a large amount of densifier was added to Hole (5G-1) to raise the fluid density. Drilling was continued, and reached $3350 \mathrm{~m}$ by January 1996 using the KEMS-132 drill with a cutter diameter of $135 \mathrm{~mm}$. The hole was enlarged to $137 \mathrm{~mm}$ every $25-30 \mathrm{~m}$. Increasing difficulties with chip collection in the warmer $\left(-10^{\circ} \mathrm{C}\right)$ ice after $3000 \mathrm{~m}$ resulted in shorter cores and the eventual stoppage of drilling (Kudryashov et al. 1998ab, 2000, 2002).

\section{6-97, Forty-second RAE: Vostok}

Vostok Station was reopened and the drilling of Hole (5G-1) was resumed with the KEMS-132 electro-mechanical drill. After some drill design modifications, Hole (5G-1) reached $3523 \mathrm{~m}$ by January 1997. By the end of the season, the same chip collection problems reoccurred, again completely stopping drilling (Kudryashov et al. 2002).

\section{7-98, Forty-third RAE: Vostok}

Continuing difficulties at the beginning of the season resulted in a radical redesign of the cutter geometry before drilling in Hole $(5 \mathrm{G}-1)$ resumed. Drilling was stopped at $3623 \mathrm{~m}$ in January 1998, 130-150 m above Lake Vostok. The hole is vertical down to $2200 \mathrm{~m}$ and deviates $6-8^{\circ}$ below this (Fig. 17). The average density of the hole fluid was $928 \mathrm{~kg} / \mathrm{m}^{3}$ (Kudryashov et al. 2002a; Verkulich et al. 2002).

\section{8-99, Forty-fourth RAE: Vostok}

During the summer season, geophysical investigations (thermometry and hole diameter measurements) were carried out in Hole (5G-1). Hole (5G-1) had the following final diameters:

- $139.0 \mathrm{~mm}$ in the interval from $2200-3095 \mathrm{~m}$.

- $138.4 \mathrm{~mm}$ in the interval from $3095-3321 \mathrm{~m}$.

- $137.9 \mathrm{~mm}$ in the interval from $3321-3500 \mathrm{~m}$.

- $136.2 \mathrm{~mm}$ in the interval from $3500-3570 \mathrm{~m}$.

- $135.0 \mathrm{~mm}$ in the interval from $3570-3623 \mathrm{~m}$. 


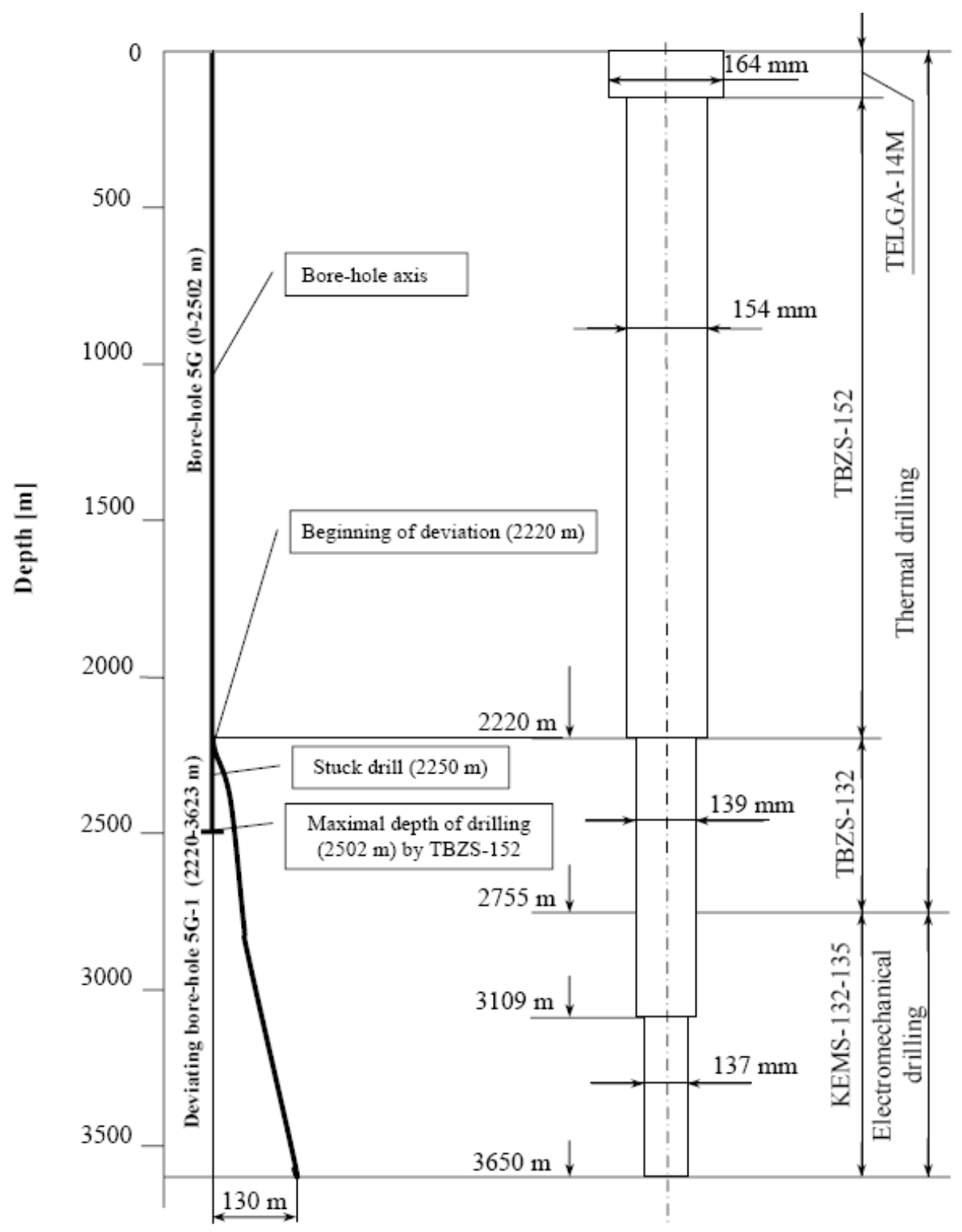

Figure 17. History of hole (5G) (from Kudryashov et al. 2002).

\section{9-00, Forty-fifth RAE}

A technique for the continued penetration of Hole (5G-1) to Lake Vostok was being studied (Verkulich et al. 2002).

\section{0-01, Forty-sixth RAE}

Project Basis and Design of an Environmentally Sensitive Penetration to Lake Vostok, Antarctica prepared by SPSMI and AARI was approved by the Ministry of Nature Resources of Russian Federation (Order № 257, 26 March 2001). 


\section{1-02, Forty-seventh RAE}

The design and fabrication of a system and technique for the penetration to Lake Vostok was continued.

\section{2-03, Forty-eighth RAE: Vostok}

Vostok Station was closed again for the winter. The XXVI Antarctic Consultive Treaty Meeting, Madrid 2003, adopted the Russian Project for the penetration to Lake Vostok.

\section{3-04, Forty-ninth RAE: Vostok}

Vostok Station was reopened and seasonal operations were organized. Two specialists from SPSMI carried out geophysical investigations and prepared for the summer season of the $5 \mathrm{O}^{\text {th }} \mathrm{RAE}$ when the continuation of drilling is planned.

\section{4-05, Fiftieth RAE: Vostok}

During the summer season, geophysical investigations (hole diameter and hydrostatic pressure measurements) were carried out in Hole (5G-1).

\section{5-06, Fifty-first RAE: Vostok}

After 8 years Hole (5G-1) was reopened for drilling again. At the beginning of the summer season, the drilling equipment and the hole itself were carefully inspected. On 31 October 2005, the first productive run was made by the electro-mechanical drill KEMS-135 and $1.5 \mathrm{~m}$ of new core was recovered. The new geometry of cutters for drilling of "warm ice" was tested and it gave stabilization to the drilling process. As a result, Hole (5G-1) was deepened to $3650.2 \mathrm{~m}$ (Fig. 18), with an average core length of $0.7-0.8 \mathrm{~m}$ per run. On 25 January 2006, the seasonal operations at Vostok ceased. Next season, additional drilling of the hole to a depth of near $3720 \mathrm{~m}$ is planned, leaving about a 30-m-thick ice layer to prevent contamination of the sub-glacial lake by drilling fluid. 


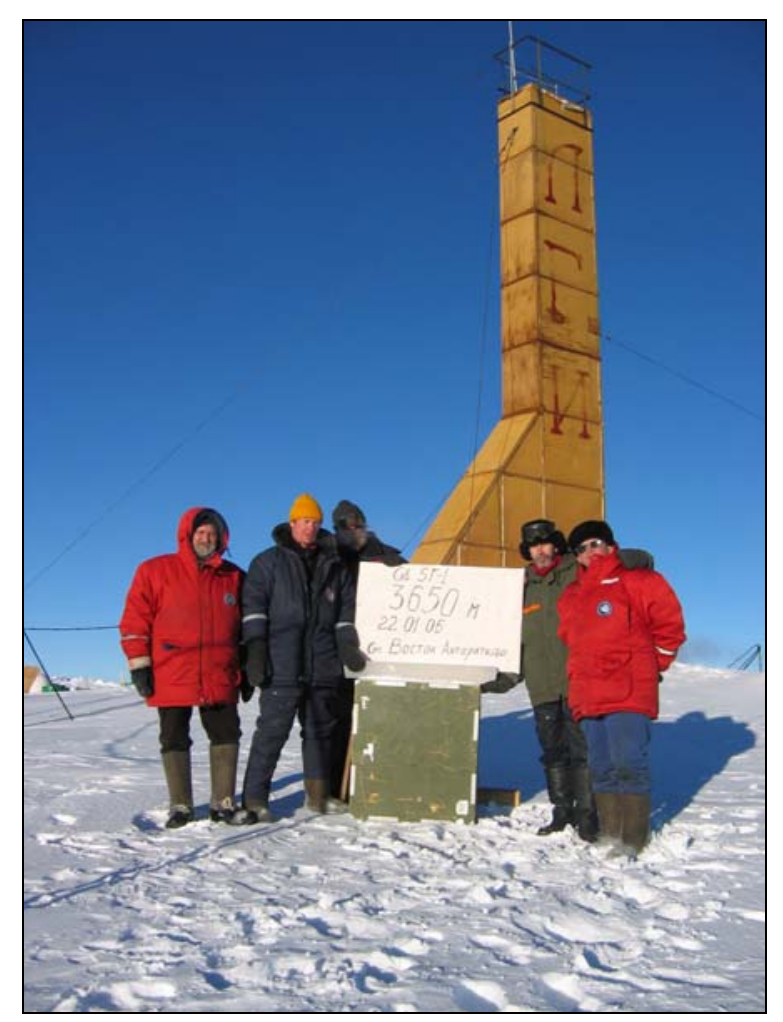

Figure 18. Vostok, 2006. Drilling team of the 2005-2006 season with record core from the depth of $3650 \mathrm{~m}$. From left to right: A. Krasilev, A. Ekaikin, V. Zubkov, A. Dmitriev, and N. Vasiliev (photograph by RAE 51).

\section{Summary}

During the past 50 years there have been over 40 boreholes-mostly with core retrieval-drilled in Antarctica by the various Soviet-Russian Antarctic Expeditions. Most of the drilling has been accomplished by the AARI, LMI (SPSMI). Of the more than $23 \mathrm{~km}$ of ice drilled, the majority was done with thermal drills. The KEMS cable suspended electro-mechanical drills were developed in the early 1980 s by the SPSMI and used successfully in Hole 4-G during SAE-34 and Hole 5-G during RAE-40-43 and RAE 51. The deepest holes were drilled at Vostok Station but several holes of significant depth have been drilled on the ice shelves and in and along the Mirny-Vostok route.

The deepest dry hole was $952 \mathrm{~m}$ (Vostok, Hole-1), made with a TELGA14M thermal drill during SAE-17. The deepest fluid-filled hole (Vostok, Hole 5G-1), made with a TBZS-132 thermal drill, reached $2755 \mathrm{~m}$ during RAE-38. The deepest fluid-filled hole was made with a KEMS-132 electromechanical drill (Vostok, Hole 5G-1) and was stopped above Lake Vostok 
during RAE-43 in 1998 at a depth of $3623 \mathrm{~m}$; it was continued to a depth of 3650 m during RAE-51 in 2006 with a KEMS-135 drill.

Seventeen holes were drilled with an AFTD or ATED drill invented by V.A. Morev in 1972. The drill used an alcohol-water solution for dissolving the melt water, the dilute solution then remaining in the hole to provide the necessary hydrostatic pressure. An 812-m hole at Novolazarezkaya Station during SAE-22 and a 872-m hole at Komsomolskya Station in SAE-28 were drilled with this type of drill.

All of the deep holes at Vostok have undergone at least one offset drilling operation because of problems with lost drills. These deviations were made successfully with a thermal drilling technique. 


\section{Soviet and Russian Drilling Activity in the Arctic and Non-Polar Regions}

\section{Introduction}

Various kinds of glaciers have a widespread occurrence in the territory of the former USSR. The glaciated area was estimated to be $78,300 \mathrm{~km}^{2}$ or nearly a half percent of the total area of the former USSR (Dolgushin and Osipova 1989). The largest and thickest glaciers are situated in the Arctic area on the archipelagoes of Novaya Zemlya, Severnaya Zemlya, and Zemlya Frantsa-Iosifa (Franz-Josef Land). The total area of glaciers in the Russian Arctic is estimated to be $56,200 \mathrm{~km}^{2}$. The non-polar or Alpine glaciers are widespread in the so-called South Mountain Surround of the former USSR, which includes multi-branched orogenic systems of the Caucasus, Tien Shan, and Pamirs.

The systematic investigations of Arctic and non-polar glaciers were started in the 1950's in anticipation of and in conjunction with the International Geophysical Year (1957-1958). For thermal and dynamic studies of glaciers, the lightweight hand drilling equipment of E.N. Tsykin's design was used. More than 100 holes were drilled, with a maximum depth of $52.6 \mathrm{~m}$. We have decided to include this drilling experience in our review as well as subsequent manual drilling of boreholes with depths of not less than 15$20 \mathrm{~m}$. Eventually, special thermal and electro-mechanical drilling equipment was designed and applied in glaciological investigations (Tables 7 and 8). In some instances, the Arctic drilling programs were conducted as pilot projects in preparation for drilling in Antarctica and were considered field drilling tests. The last ice coring programs were focused on the climatic record variations over the last 2000 years, which have witnessed the most extreme conditions of the entire Holocene.

The first attempt to compile information on Soviet and Russian drilling activity in the Arctic was carried out by S.M. Arkhipov of the Institute of Geography Russian Academy of Science (IGRAS or IGAS), who created a computer database Deep Drilling of Glaciers: Soviet and Russian Projects in the Arctic, 1975- 1990 (Arkhipov 1999). Unfortunately this database was published only in fragments and with an emphasis on core analysis and bore hole measurements rather than on drilling technology. It contains 
data from 12 cored boreholes deeper than $100 \mathrm{~m}$, which included 8 holes on Spitsbergen and 4 holes on Severnaya Zemlya. It should be noted that this list is incomplete. It is known that at least 15 cored boreholes with depths of 100-761 m were drilled on Severnaya Zemlya (Table 9).

Table 7. Soviet Drilling activity In the Arctic and non-polar regions.*

\begin{tabular}{|c|c|c|c|c|c|}
\hline Year & $\begin{array}{l}\text { Site Location } \\
\text { (Site Number**) }\end{array}$ & Organization & $\begin{array}{l}\text { No. of holes, depths } \\
\text { or total depth, } m\end{array}$ & $\begin{array}{l}\text { Type of drilling } \\
\text { equipment }\end{array}$ & References \\
\hline \multicolumn{6}{|c|}{ ARCTIC } \\
\hline $\begin{array}{l}1955- \\
1959\end{array}$ & Franz Josef Land & \multirow[t]{3}{*}{ IGAS } & 20 holes & \multirow[t]{3}{*}{$\begin{array}{l}\text { Hand ice drills of } \\
\text { E.N.Tsykin }\end{array}$} & \multirow[t]{3}{*}{$\begin{array}{l}\text { Tsykin, 1962; 1963a; } \\
\text { 1963b; 1963c }\end{array}$} \\
\hline $\begin{array}{l}1958- \\
1960\end{array}$ & Polar Urals & & 23 holes & & \\
\hline $\begin{array}{l}1958- \\
1959\end{array}$ & Novaya Zemlya & & 16 holes & & \\
\hline $\begin{array}{l}1958- \\
1959\end{array}$ & $\begin{array}{l}\text { Churlyenis Gla- } \\
\text { cier (Franz Josef } \\
\text { Land) }\end{array}$ & IGAS & $\begin{array}{l}\text { A few holes with } \\
\text { depths from } 20 \text { to } 82 \\
\text { m }\end{array}$ & $\begin{array}{l}\text { Self-propelled drill- } \\
\text { ing rig SBU-150-ZIV }\end{array}$ & Bazanov, 1961 \\
\hline 1965 & $\begin{array}{l}\text { Noredenskiöld } \\
\text { Glacier (Spits- } \\
\text { bergen) }\end{array}$ & IGAS & $\begin{array}{l}\text { A few holes with } \\
\text { maximum depth of } \\
25 \mathrm{~m}\end{array}$ & Hand ice drills & Koryakin, 1981 \\
\hline \multirow[t]{2}{*}{1972} & \multirow[t]{2}{*}{$\begin{array}{l}\text { Drifting station } \\
\text { Severnyi Polyus- } \\
19 \\
\text { (Arctic Ocean) }\end{array}$} & \multirow[t]{2}{*}{ AARI } & $\begin{array}{l}\text { Dozens of holes (total } \\
\text { depth of near } 300 \mathrm{~m} \\
\text { with maximum depth } \\
\text { of } 34 \mathrm{~m} \text { ) }\end{array}$ & $\begin{array}{l}\text { Thermo-electric } \\
\text { point “Elektroigla } \\
\text { ETI-1" }\end{array}$ & \multirow[t]{2}{*}{ Morev, 1976} \\
\hline & & & $\begin{array}{l}\text { A few holes with total } \\
\text { depth } 45 \text { m (maxi- } \\
\text { mum depth of } 34 \mathrm{~m} \text { ) }\end{array}$ & ATED & \\
\hline \multirow[t]{2}{*}{$\begin{array}{l}1973 \\
1974\end{array}$} & \multirow[t]{2}{*}{$\begin{array}{l}\text { Obruchev Glacier } \\
\text { (Polar Urals) }\end{array}$} & \multirow[t]{2}{*}{ IGAS } & $\begin{array}{l}28 \text { holes with total } \\
\text { depth of } 1426 \mathrm{~m} \\
(\max 137 \mathrm{~m})\end{array}$ & $\begin{array}{l}\text { Thermo-electric } \\
\text { point “Elektroigla } \\
\text { ETI-1" }\end{array}$ & \multirow[t]{2}{*}{$\begin{array}{l}\text { Morev, 1976; } \\
\text { Zagorodnov et al., } \\
1976\end{array}$} \\
\hline & & & 86 & ATED & \\
\hline $\begin{array}{l}1990- \\
1991\end{array}$ & $\begin{array}{l}\text { Loonnyi Glacier } \\
\text { (Franz Josef } \\
\text { Land) }\end{array}$ & IGAS & $\begin{array}{l}53.6 \\
50\end{array}$ & $\begin{array}{l}\text { Drilling method } \\
\text { wasn't reported }\end{array}$ & Macheret et al., 1993 \\
\hline 1994 & Franz Josef Land & $\begin{array}{l}\text { IGRAS, } \\
\text { Byrd Polar Re- } \\
\text { search Center }\end{array}$ & $10 ; 6 ; 24 ; 24$ & Hand coring auger & $\begin{array}{l}\text { Mikhalenko et al., } \\
1996\end{array}$ \\
\hline 1997 & $\begin{array}{l}\text { Windy Glacier } \\
\text { (Franz Josef } \\
\text { Land) }\end{array}$ & $\begin{array}{l}\text { IGRAS, } \\
\text { Byrd Polar Re- } \\
\text { search Center }\end{array}$ & $\begin{array}{l}36.4 ; \\
314.8\end{array}$ & m-ATED & $\begin{array}{l}\text { Zagorodnov et al., } \\
\text { 1998; } \\
\text { Arkhipov et al., } 2001\end{array}$ \\
\hline
\end{tabular}




\begin{tabular}{|c|c|c|c|c|c|}
\hline Year & $\begin{array}{l}\text { Site Location } \\
\text { (Site Number**) }\end{array}$ & Organization & $\begin{array}{l}\text { No. of holes, depths } \\
\text { or total depth, } m\end{array}$ & $\begin{array}{l}\text { Type of drilling } \\
\text { equipment }\end{array}$ & References \\
\hline \multicolumn{6}{|c|}{ CENTRAL ASIA } \\
\hline $\begin{array}{l}1956- \\
1957\end{array}$ & $\begin{array}{l}\text { Terskei Alatau } \\
\text { (Internal Tien } \\
\text { Shan) }\end{array}$ & \multirow{2}{*}{$\begin{array}{l}\text { IGAS, Geography } \\
\text { Department of } \\
\text { Academy of Sci- } \\
\text { ences of Kazakh } \\
\text { SSR }\end{array}$} & 24 holes & \multirow[t]{2}{*}{$\begin{array}{l}\text { Hand ice drills of } \\
\text { E.N.Tsykin }\end{array}$} & \multirow{2}{*}{$\begin{array}{l}\text { Tsykin, 1962; 1963a; } \\
\text { 1963b; 1963c; } \\
\text { Vilesov and Shabanov, } \\
\text { 1961; Tsykina and } \\
\text { Vilesov, } 1963\end{array}$} \\
\hline $\begin{array}{l}1957- \\
1959\end{array}$ & $\begin{array}{l}\text { Zailiiskii Alatau } \\
\text { (Northern Tien } \\
\text { Shan) }\end{array}$ & & 30 holes & & \\
\hline 1964 & $\begin{array}{l}\text { Tuiuksu Glacier } \\
\text { (Zailiiskii Alatau, } \\
\text { Northern Tien } \\
\text { Shan), \# CA1 }\end{array}$ & $\begin{array}{l}\text { Kazakh Poly- } \\
\text { technic Institute, } \\
\text { Geography De- } \\
\text { partment of } \\
\text { Academy of Sci- } \\
\text { ences of Kazakh } \\
\text { SSR }\end{array}$ & $33 ; 23$ & Jet-fire drill & Brichkin et al., 1967 \\
\hline 1965 & $\begin{array}{l}\text { Karabatkak Gla- } \\
\text { cier (Terskei } \\
\text { Alatau, Internal } \\
\text { Tien Shan), \# } \\
\text { CA2 }\end{array}$ & IGAS & 49 & $\begin{array}{l}\text { Cable-percussion } \\
\text { drilling rig }\end{array}$ & Tsykin, 1966 \\
\hline 1969 & $\begin{array}{l}\text { Tuiuksu Glacier } \\
\text { (Zailiiskii Alatau, } \\
\text { Northern Tien } \\
\text { Shan), \#CA1 }\end{array}$ & $\begin{array}{l}\text { Kazakh Poly- } \\
\text { technic Institute, } \\
\text { Geography De- } \\
\text { partment of } \\
\text { Academy of Sci- } \\
\text { ences of Kazakh } \\
\text { SSR }\end{array}$ & $\begin{array}{l}28 \\
53.5 \\
72 ; \\
53\end{array}$ & Jet-fire drill & $\begin{array}{l}\text { Mikheev, 1971; } \\
\text { Makarevich et al., } \\
1984\end{array}$ \\
\hline 1971 & $\begin{array}{l}\text { Abramov Glacier } \\
\text { (Alai Ridge, Pa- } \\
\text { mirs), \#CA3 }\end{array}$ & $\begin{array}{l}\text { AARI, } \\
\text { SARNIGMI }\end{array}$ & 2 holes & $\begin{array}{l}\text { Thermo-electric } \\
\text { point “Elektroigla } \\
\text { ETI-1" }\end{array}$ & Ruymin et al., 1974 \\
\hline \multirow[t]{2}{*}{1972} & & & $\begin{array}{l}\text { A few holes with total } \\
\text { depth of } 375 \mathrm{~m} \text { (max } \\
175 \mathrm{~m})\end{array}$ & $\begin{array}{l}\text { Thermo-electric } \\
\text { point “Elektroigla } \\
\text { ETI-1" }\end{array}$ & Sukhanov et al., 1974 \\
\hline & & & 113 & $\begin{array}{l}\text { Thermal drill } \\
\text { LKTBM-1 }\end{array}$ & \\
\hline 1973 & & & 50.7 & Thermal Coring drill & $\begin{array}{l}\text { Kislov and Nos- } \\
\text { dryukhin, } 1975\end{array}$ \\
\hline 1974 & & & 105.8 & Thermal Coring drill & Kislov, 1976 \\
\hline 1985 & $\begin{array}{l}\text { Davydov Glacier } \\
\text { (Akshirak, Inter- } \\
\text { nal Tien Shan), } \\
\text { \#CA4 }\end{array}$ & $\begin{array}{l}\text { LMI, } \\
\text { IGAS }\end{array}$ & 109 & $\begin{array}{l}\text { Thermo-electric } \\
\text { point TBI-70-P }\end{array}$ & $\begin{array}{l}\text { Vasilenko et al., 1988; } \\
\text { Aizen and Zakharov, } \\
1989\end{array}$ \\
\hline $\begin{array}{l}1989 \\
1990\end{array}$ & $\begin{array}{l}\text { South Inylchek } \\
\text { Glacier (Central } \\
\text { Tien Shan), \#CA5 }\end{array}$ & $\begin{array}{l}\text { IGAS, } \\
\text { Scott Polar Re- } \\
\text { search Institute }\end{array}$ & $30 \mathrm{~m}$ & PICO hand drill & $\begin{array}{l}\text { Aizen et al., } 1990 \text { and } \\
1993\end{array}$ \\
\hline
\end{tabular}




\begin{tabular}{|c|c|c|c|c|c|c|}
\hline Year & $\begin{array}{l}\text { Site Location } \\
\text { (Site Number**) }\end{array}$ & Organization & \multicolumn{2}{|c|}{$\begin{array}{l}\text { No. of holes, depths } \\
\text { or total depth, } m\end{array}$} & $\begin{array}{l}\text { Type of drilling } \\
\text { equipment }\end{array}$ & References \\
\hline & & $\begin{array}{l}\text { IGAS, } \\
\text { LMI }\end{array}$ & \multicolumn{2}{|l|}{$21 \mathrm{~m}$} & $\begin{array}{l}\text { Thermal coring drill } \\
\text { MTBS }\end{array}$ & \\
\hline 1990 & $\begin{array}{l}\text { Grigor'ev Glacier } \\
\text { (Terskei Alatau, } \\
\text { Internal Tien } \\
\text { Shan), \#CA6 }\end{array}$ & $\begin{array}{l}\text { IGAS, } \\
\text { Byrd Polar Re- } \\
\text { search Center }\end{array}$ & \multicolumn{2}{|l|}{$20 ; 16.5$} & PICO hand drill & Thompson et al., 1997 \\
\hline $\begin{array}{l}1990, \\
1991\end{array}$ & $\begin{array}{l}\text { South-eastern } \\
\text { Tibet and North- } \\
\text { ern slope of Hi- } \\
\text { malayas }\end{array}$ & $\begin{array}{l}\text { IGAS, Academy of } \\
\text { Sciences of Chi- } \\
\text { na }\end{array}$ & \multicolumn{2}{|l|}{$18 ; 42$} & $\begin{array}{l}\text { Chinese thermal } \\
\text { coring electric drill }\end{array}$ & $\begin{array}{l}\text { V.Aizen, personal } \\
\text { communication }\end{array}$ \\
\hline 2000 & $\begin{array}{l}\text { Rvanniy Glacier, } \\
\text { South Inylchek } \\
\text { (Central Tien } \\
\text { Shan) }\end{array}$ & $\begin{array}{l}\text { US Department } \\
\text { of Energy (DOE) } \\
\text { and National } \\
\text { Science Founda- } \\
\text { tion (NSF) }\end{array}$ & \multicolumn{2}{|l|}{$\begin{array}{l}165 \\
167\end{array}$} & $\begin{array}{l}\text { ECLIPSE electro- } \\
\text { mechanical drill } \\
\text { (Icefield Instru- } \\
\text { ments Inc., Can- } \\
\text { ada) }\end{array}$ & $\begin{array}{l}\text { V.Aizen, personal } \\
\text { communication }\end{array}$ \\
\hline \multicolumn{7}{|c|}{ CAUCASUS } \\
\hline 1963 & $\begin{array}{l}\text { Elbrus (Central } \\
\text { Caucasus), \#C1 }\end{array}$ & IGAS & \multicolumn{2}{|l|}{$\begin{array}{l}6 \text { holes from } 28 \text { to } \\
40 \mathrm{~m}\end{array}$} & $\begin{array}{l}\text { Cable-percussion } \\
\text { drilling rig }\end{array}$ & Tsykin, 1966 \\
\hline 1966 & $\begin{array}{l}\text { Bazengi (West } \\
\text { Caucasus), \#C2 }\end{array}$ & IGAS & \multicolumn{2}{|l|}{$\begin{array}{l}\text { A few holes } \\
\text { up to } 150 \mathrm{~m}\end{array}$} & $\begin{array}{l}\text { Cable-percussion } \\
\text { drilling rig }\end{array}$ & $\begin{array}{l}\text { Psar'eva et al., } 1968 \\
\text { Tsykin, } 1970\end{array}$ \\
\hline 1967 & $\begin{array}{l}\text { Marukh Glacier } \\
\text { (West Caucasus), } \\
\text { \#C3 }\end{array}$ & IGAS & \multicolumn{2}{|c|}{$\begin{array}{l}\text { Three holes }(45,50 \\
\text { and } 78)\end{array}$} & $\begin{array}{l}\text { Cable-percussion } \\
\text { drilling rig }\end{array}$ & $\begin{array}{l}\text { Tsykin, 1970; } \\
\text { Bazheva and Krenke, } \\
\text { 1970; Bazheva and } \\
\text { Psar'eva, 1973; } \\
\text { Krenke et al., } 1988\end{array}$ \\
\hline 1969 & & $\begin{array}{l}\text { IGAS, } \\
\text { Moscow State } \\
\text { University }\end{array}$ & \multicolumn{2}{|l|}{$20 \mathrm{~m}(?)$} & $\begin{array}{l}\text { Thermo-electric } \\
\text { point }\end{array}$ & Sukhanov et al., 1974 \\
\hline $\begin{array}{l}1970 \\
1971\end{array}$ & \multirow[t]{3}{*}{$\begin{array}{l}\text { Jankuat Glacier } \\
\text { (Central Cauca- } \\
\text { sus), \#C4 }\end{array}$} & \multirow[t]{3}{*}{$\begin{array}{l}\text { Moscow State } \\
\text { University }\end{array}$} & $\begin{array}{l}\text { Five holes with } \\
\text { total depth of } \\
405 \mathrm{~m}(\max 111 \\
\mathrm{m})\end{array}$ & \multirow{3}{*}{ 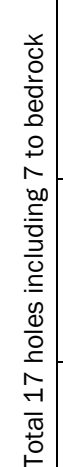 } & $\begin{array}{l}\text { Thermo-electric } \\
\text { point Elektroigla } \\
\text { ETI-1 }\end{array}$ & $\begin{array}{l}\text { Sukhanov, 1973; } \\
\text { Sukhanov et al., } 1974\end{array}$ \\
\hline 1972 & & & $\begin{array}{l}\text { A few holes with } \\
\text { total depth of } \\
160 \mathrm{~m}(\max 51 \\
\mathrm{m})\end{array}$ & & $\begin{array}{l}\text { Thermo-electric } \\
\text { point Mikroteb-1 }\end{array}$ & $\begin{array}{l}\text { Sukhanov et al., 1974; } \\
\text { Golubev et al., } 1976\end{array}$ \\
\hline 1973 & & & $\begin{array}{l}\text { A few holes } \\
(\max 71 \mathrm{~m})\end{array}$ & & $\begin{array}{l}\text { Thermo-electric } \\
\text { point }\end{array}$ & Golubev et al., 1976 \\
\hline 1983 & $\begin{array}{l}\text { Dzhantugan- } \\
\text { skoye Firn Pla- } \\
\text { teau (Central } \\
\text { Caucasus), \#C5 }\end{array}$ & $\begin{array}{l}\text { IGAS, } \\
\text { LMI }\end{array}$ & \multicolumn{2}{|l|}{93} & $\begin{array}{l}\text { Thermal drill } \\
\text { MTBS-76 }\end{array}$ & $\begin{array}{l}\text { Golubev et al., 1988; } \\
\text { Vasiliev et al., 1993b }\end{array}$ \\
\hline 1987 & $\begin{array}{l}\text { Garabashi Gla- } \\
\text { cier (Elbrus, Cen- }\end{array}$ & IGAS & \multicolumn{2}{|c|}{$\begin{array}{l}\text { Two holes (73.2 and } \\
77.7 \mathrm{~m})\end{array}$} & $\begin{array}{l}\text { Thermo-electric } \\
\text { point }\end{array}$ & $\begin{array}{l}\text { Bazhev et al., 1988; } \\
\text { Zagorodnov et al., }\end{array}$ \\
\hline
\end{tabular}




\begin{tabular}{|c|c|c|c|c|c|}
\hline Year & $\begin{array}{l}\text { Site Location } \\
\text { (Site Number**) }\end{array}$ & Organization & $\begin{array}{l}\text { No. of holes, depths } \\
\text { or total depth, } m\end{array}$ & $\begin{array}{l}\text { Type of drilling } \\
\text { equipment }\end{array}$ & References \\
\hline 1988 & $\begin{array}{l}\text { tral Caucasus), } \\
\# C 6\end{array}$ & & $\begin{array}{l}76.7 \\
76.0\end{array}$ & ATED ETB-3 & 1991 \\
\hline 1990 & $\begin{array}{l}\text { Bolshoi Azau } \\
\text { Glacier (Elbrus, } \\
\text { Central Cau- } \\
\text { cuses), \#C7 }\end{array}$ & IGAS & $\begin{array}{l}\text { Two holes with depth } \\
\text { of } 17 \mathrm{~m}\end{array}$ & Hand auger drill & Rotataeva et al., 1998 \\
\hline \multicolumn{6}{|c|}{ KAMCHATKA } \\
\hline 1975 & Kozel'skii Glacier & - & $\begin{array}{l}12 \\
20\end{array}$ & $\begin{array}{l}\text { Conventional port- } \\
\text { able boring appara- } \\
\text { tus UKB-12/25 }\end{array}$ & $\begin{array}{l}\text { Vinogradov et al., } \\
1981\end{array}$ \\
\hline $\begin{array}{l}1996, \\
1998\end{array}$ & $\begin{array}{l}\text { Gorshkov Glacier } \\
\text { (Ushkovskii Vol- } \\
\text { cano, Kam- } \\
\text { chatka) }\end{array}$ & $\begin{array}{l}\text { Russian- } \\
\text { Japanese } \\
\text { Cryosphere Re- } \\
\text { search Project }\end{array}$ & $\begin{array}{l}27 ; \\
211.7\end{array}$ & $\begin{array}{l}\text { Electro-mechanical } \\
\text { ice coring drill D-2 } \\
\text { (Geo. Tecs Co., } \\
\text { Ltd., Japan) }\end{array}$ & $\begin{array}{l}\text { Shiraiwa et al., 1999a; } \\
\text { Shiraiwa et al., 1999b; } \\
\text { Salamatin et al., } \\
\text { 2001; } \\
\text { Shiraiwa et al., } 2001\end{array}$ \\
\hline \multicolumn{6}{|c|}{ ALTAI MOUNTAINS } \\
\hline \multirow[t]{2}{*}{$\begin{array}{l}2000 \\
2001\end{array}$} & $\begin{array}{l}\text { Eastern Plateau } \\
\text { of Mt. Belukha }\end{array}$ & $\begin{array}{l}\text { Swiss-Russian } \\
\text { Research Project }\end{array}$ & 138 & $\begin{array}{l}\text { Felix electro- } \\
\text { mechanical drill } \\
\text { (FS Inventor AG, } \\
\text { Switzerland) }\end{array}$ & $\begin{array}{l}\text { V.Aizen, personal } \\
\text { communication }\end{array}$ \\
\hline & Sofiyskiy Glacier & $\begin{array}{l}\text { Russian-Japanese } \\
\text { Research Project }\end{array}$ & $\begin{array}{l}12.3 \\
9 \\
25.1\end{array}$ & Hand drills & Fujii, et al. 2002 \\
\hline 2003 & $\begin{array}{l}\text { Western Plateau of } \\
\text { Mt. Belukha }\end{array}$ & $\begin{array}{l}\text { Russian-Japanese } \\
\text { Research Project }\end{array}$ & $\begin{array}{l}171.3 \\
48\end{array}$ & $\begin{array}{l}\text { Modified electro- } \\
\text { mechanical ice coring } \\
\text { drill D-2 (Geo. Tecs } \\
\text { Co., Ltd., Japan) }\end{array}$ & Takeuchi et al., 2004 \\
\hline
\end{tabular}

*Except drilling operations specified in Tables 9 and 10.

** Site numbers see Fig. 21 and 23.

Table 8. Main characteristics of thermal points and drills.

\begin{tabular}{|l|l|l|l|l|l|l|}
\hline Type & $\begin{array}{l}\text { Maximum } \\
\text { drilling } \\
\text { depth, } \mathrm{m}\end{array}$ & $\begin{array}{l}\text { OD/ID of drill } \\
\text { head, } \mathrm{mm}\end{array}$ & $\begin{array}{l}\text { Power of } \\
\text { drill head, } \\
\mathrm{kW}\end{array}$ & $\begin{array}{l}\text { Length of } \\
\text { core barrel, } \\
\mathrm{m}\end{array}$ & $\begin{array}{l}\text { Length of } \\
\text { drill, } \mathrm{m}\end{array}$ & $\begin{array}{l}\text { Weight of } \\
\text { drill, } \mathrm{kg}\end{array}$ \\
\hline “Elektroigla" ETI-1 & 175 & $\begin{array}{l}40 \text { (full- } \\
\text { diameter) }\end{array}$ & 2.5 & - & 1.3 & 5 \\
\hline LKTBM-1 & 113 & $116 / 88$ & 4.0 & 1.4 & 1.5 & 25 \\
\hline ETB-1 & - & $108 / 84$ & $1-3$ & $1.0-3.0$ & $1.5-3.5$ & $15-40$ \\
\hline Mikroteb-1 & 51 & $\begin{array}{l}20 \text { (full- } \\
\text { diameter) }\end{array}$ & $0.2-0.37$ & - & 1 & 2 \\
\hline TBSK-93 & 130 & $93 / 74$ & $1.25-1.8$ & 2.8 & 5.9 & 80 \\
\hline TBS-93 & 45 & $96 / 77$ & $2.5-3.3$ & 2.4 & 4.7 & 40 \\
\hline TBS-93VCh & 49 & $95 / 77$ & $2.5-5$ & 2.7 & 4.9 & 50 \\
\hline
\end{tabular}




\begin{tabular}{|l|l|l|l|l|l|l|}
\hline Type & $\begin{array}{l}\text { Maximum } \\
\text { drilling } \\
\text { depth, } \mathrm{m}\end{array}$ & $\begin{array}{l}\text { OD/ID of drill } \\
\text { head, } \mathrm{mm}\end{array}$ & $\begin{array}{l}\text { Power of } \\
\text { drill head, } \\
\mathrm{kW}\end{array}$ & $\begin{array}{l}\text { Length of } \\
\text { core barrel, } \\
\mathrm{m}\end{array}$ & $\begin{array}{l}\text { Length of } \\
\text { drill, } \mathrm{m}\end{array}$ & $\begin{array}{l}\text { Weight of } \\
\text { drill, } \mathrm{kg}\end{array}$ \\
\hline MTBS-66 & 13 & $66 / 49$ & 0.7 & 0.7 & 1 & 16 \\
\hline MTBS-76 & 93 & $76 / 66$ & 1.0 & 2.0 & 2.3 & 18 \\
\hline MTBS-100 & 68 & $100 / 75$ & 1.0 & 1.5 & 1.8 & 13 \\
\hline PTBS-112 & 50 & $112 / 98$ & $\approx 4^{*}$ & 2.5 & 5.4 & 75 \\
\hline TBI-70-P & 109 & $\begin{array}{l}70(\text { full- } \\
\text { diameter) }\end{array}$ & 1 & - & 1.2 & 12 \\
\hline m-ATED & 315 & $124 / 105$ & 3.3 & 2.1 & 2.9 & 25 \\
\hline
\end{tabular}

*Power of hot-water generator.

Table 9. AARI, IGAS and LMI (SPSMI) drilling on Severnaya Zemlya.

\begin{tabular}{|c|c|c|c|c|}
\hline Year & $\begin{array}{l}\text { Site Location (Site } \\
\text { Number*) }\end{array}$ & $\begin{array}{l}\text { No. of holes,- } \\
\text { hole depth or } \\
\text { drilling interval, } \\
\mathrm{m}\end{array}$ & $\begin{array}{l}\text { Type of drilling } \\
\text { equipment }\end{array}$ & References \\
\hline \multirow{3}{*}{1974} & $\begin{array}{l}\text { Vavilov Glacier } \\
\text { (Kupol Vavilova) }\end{array}$ & $80 ; 80 ; 24$ & \multirow{3}{*}{$\begin{array}{l}\text { Thermo-electric } \\
\text { point Elektroigla } \\
\text { ETI-1 }\end{array}$} & \multirow{8}{*}{ Morev and Pukhov, 1981} \\
\hline & $\begin{array}{l}\text { Vavilov Glacier } \\
\text { (North aligning, field rod No } \\
20 \text { ) }\end{array}$ & 20 & & \\
\hline & $\begin{array}{l}\text { Vavilov Glacier } \\
\text { (North aligning, field rod No } \\
\text { 9) }\end{array}$ & 20 & & \\
\hline 1975 & $\begin{array}{l}\text { Vavilov Glacier } \\
\text { (Kupol Vavilova) }\end{array}$ & 60 & $\begin{array}{l}\text { Thermo-electric } \\
\text { point Elektroigla } \\
\text { ETI-1 }\end{array}$ & \\
\hline \multirow{3}{*}{1976} & $\begin{array}{l}\text { Vavilov Glacier } \\
\text { (Kupol Vavilova) }\end{array}$ & 17 & \multirow[t]{2}{*}{ ATED ETB-3 } & \\
\hline & \multirow{2}{*}{$\begin{array}{l}\text { Vavilov Glacier } \\
\text { (North aligning, field rod No } \\
\text { 18) }\end{array}$} & 15 & & \\
\hline & & 310 & $\begin{array}{l}\text { Anti-freeze } \\
\text { thermo-electric } \\
\text { point }\end{array}$ & \\
\hline \multirow[b]{2}{*}{1977} & \multirow{5}{*}{$\begin{array}{l}\text { Vavilov Glacier } \\
\text { (Kupol Vavilova) }\end{array}$} & 459 & ATED ETB-3 & \\
\hline & & $\begin{array}{l}91.8 \\
51 \\
462.2\end{array}$ & $\begin{array}{l}\text { Thermal drill } \\
\text { TBZS-152M }\end{array}$ & \multirow[t]{4}{*}{$\begin{array}{l}\text { Zagrivnyi et al., 1981; } \\
\text { Chistyakov et al., } 1988\end{array}$} \\
\hline \multirow[t]{3}{*}{1978} & & $0-27.5$ & $\begin{array}{l}\text { Thermal drill } \\
\text { TBZS-152M }\end{array}$ & \\
\hline & & $27.5-45.3$ & $\begin{array}{l}\text { Thermal drill } \\
\text { TBS-93 }\end{array}$ & \\
\hline & & $45.3-49.3$ & $\begin{array}{l}\text { Thermal drill } \\
\text { TBS-93VCh }\end{array}$ & \\
\hline
\end{tabular}




\begin{tabular}{|c|c|c|c|c|}
\hline Year & $\begin{array}{l}\text { Site Location (Site } \\
\text { Number*) }\end{array}$ & $\begin{array}{l}\text { No. of holes,- } \\
\text { hole depth or } \\
\text { drilling interval, } \\
\mathrm{m}\end{array}$ & $\begin{array}{l}\text { Type of drilling } \\
\text { equipment }\end{array}$ & References \\
\hline & & 90 & $\begin{array}{l}\text { Thermal drill } \\
\text { TBSK-93 }\end{array}$ & \\
\hline \multirow{8}{*}{1979} & \multirow{3}{*}{$\begin{array}{l}\text { Vavilov Glacier } \\
\text { (Kupol Vavilova) }\end{array}$} & 460 & $\begin{array}{l}\text { Thermal drill } \\
\text { TBZS-152M }\end{array}$ & \multirow{3}{*}{$\begin{array}{l}\text { Zagrivnyi et al., 1979; } \\
\text { Barkov et al., 1988; } \\
\text { Chistyakov et al., } 1988\end{array}$} \\
\hline & & $\begin{array}{l}7 \text { holes with } \\
\text { total depth of } \\
35 \mathrm{~m}(\max \\
13.4 \mathrm{~m})\end{array}$ & $\begin{array}{l}\text { Thermal drill } \\
\text { MTBS-66 }\end{array}$ & \\
\hline & & $\begin{array}{l}4 \text { holes with } \\
\text { total depth of } \\
26 \mathrm{~m}(\mathrm{max} \\
16.8 \mathrm{~m})\end{array}$ & $\begin{array}{l}\text { Thermal drill } \\
\text { TBZS-152M }\end{array}$ & \\
\hline & \multirow{3}{*}{$\begin{array}{l}\text { Vavilov Glacier } \\
\text { (11 km southeast of gla- } \\
\text { ciological station Kupol Vav- } \\
\text { ilova) }\end{array}$} & $0-4.5$ & ATED ETB-3 & \multirow{3}{*}{$\begin{array}{l}\text { Morev and Pukhov, 1981; } \\
\text { Morev et al., 1981; } \\
\text { Morev et al., } 1988\end{array}$} \\
\hline & & $4.5-105$ & ATED ETB-5 & \\
\hline & & $105-556.6$ & ATED ETB-3 & \\
\hline & \multirow{2}{*}{$\begin{array}{l}\text { Vavilov Glacier } \\
\text { (Kupol Vavilova) }\end{array}$} & $0-52.4$ & $\begin{array}{l}\text { Thermal drill } \\
\text { TBZS-152M }\end{array}$ & \multirow{2}{*}{ Chistyakov et al., 1988} \\
\hline & & 52.4-95.5 & $\begin{array}{l}\text { Thermal drill } \\
\text { TBSK-93 }\end{array}$ & \\
\hline \multirow{3}{*}{1980} & $\begin{array}{l}\text { Vavilov Glacier } \\
\text { (Kupol Vavilova) }\end{array}$ & 80 & $\begin{array}{l}\text { Thermal drill } \\
\text { TBZS-152M }\end{array}$ & Chistyakov et al., 1988 \\
\hline & $\begin{array}{l}\text { Vavilov Glacier } \\
\text { (11 km southeast of gla- } \\
\text { ciological station Kupol Vav- } \\
\text { ilova) }\end{array}$ & $\begin{array}{l}4 \text { holes from } \\
10 \text { to } 25 \mathrm{~m}\end{array}$ & ATED ETB-3 & \multirow{2}{*}{ Morev et al., 1988} \\
\hline & $\begin{array}{l}\text { Vavilov Glacier } \\
\text { (5 km northwest of glaciol- } \\
\text { ogical station Kupol Vav- } \\
\text { ilova) }\end{array}$ & 57 & $\begin{array}{l}\text { Thermo-electric } \\
\text { point Elektroigla } \\
\text { ETI-1 }\end{array}$ & \\
\hline \multirow[t]{2}{*}{1981} & \multirow{2}{*}{$\begin{array}{l}\text { Vavilov Glacier } \\
\text { (Kupol Vavilova) }\end{array}$} & 52 & $\begin{array}{l}\text { Thermal drill } \\
\text { TELGA-14M }\end{array}$ & $\begin{array}{l}\text { Zemtsov and Men'shikov, } \\
\text { 1988; } \\
\text { Chistyakov et al., } 1988\end{array}$ \\
\hline & & 410 & $\begin{array}{l}\text { Thermal drill } \\
\text { TBZS-152M }\end{array}$ & Chistyakov et al., 1988 \\
\hline \multirow{2}{*}{1982} & $\begin{array}{l}\text { Vavilov Glacier } \\
\text { ( } 20 \mathrm{~km} \text { southwest of gla- } \\
\text { ciological station Kupol } \\
\text { Vavilova) }\end{array}$ & 468.5 & \multirow{2}{*}{ ATED ETB-3 } & \multirow{2}{*}{ Morev et al., 1988} \\
\hline & $\begin{array}{l}\text { Vavilov Glacier } \\
(8 \mathrm{~km} \text { northwest of glaciol- } \\
\text { ogical station Kupol } \\
\text { Vavilova) }\end{array}$ & 146 & & \\
\hline
\end{tabular}




\begin{tabular}{|c|c|c|c|c|}
\hline Year & $\begin{array}{l}\text { Site Location (Site } \\
\text { Number*) }\end{array}$ & $\begin{array}{l}\text { No. of holes,- } \\
\text { hole depth or } \\
\text { drilling interval, } \\
\text { m }\end{array}$ & $\begin{array}{l}\text { Type of drilling } \\
\text { equipment }\end{array}$ & References \\
\hline \multirow{3}{*}{1983} & $\begin{array}{l}\text { Vavilov Glacier } \\
\text { ( } 20 \mathrm{~km} \text { southwest of gla- } \\
\text { ciological station Kupol } \\
\text { Vavilova) }\end{array}$ & 467 & ATED ETB-3 & Morev et al., 1988 \\
\hline & \multirow{2}{*}{$\begin{array}{l}\text { Vavilov Glacier } \\
\text { (Kupol Vavilova) }\end{array}$} & 200 & $\begin{array}{l}\text { Thermal drill } \\
\text { TELGA-152M }\end{array}$ & \multirow{2}{*}{$\begin{array}{l}\text { Zemtsov and Men'shikov, } \\
\text { 1988; Chistyakov et al., } \\
1988\end{array}$} \\
\hline & & 100 & $\begin{array}{l}\text { Thermal drill } \\
\text { TELGA-152M }\end{array}$ & \\
\hline \multirow{3}{*}{1984} & $\begin{array}{l}\text { Vavilov Glacier } \\
\text { (11 km southwest of gla- } \\
\text { ciological station Kupol } \\
\text { Vavilova) }\end{array}$ & 110 & $\begin{array}{l}\text { Thermal drill } \\
\text { ETB-130 }\end{array}$ & Morev et al., 1988 \\
\hline & \multirow{2}{*}{$\begin{array}{l}\text { Vavilov Glacier } \\
\text { (Kupol Vavilova) }\end{array}$} & $0-30$ & $\begin{array}{l}\text { Thermal drill } \\
\text { TELGA-152M }\end{array}$ & \multirow{2}{*}{$\begin{array}{l}\text { Bobin et al., 1988; Kudrya- } \\
\text { shov et al., 1989; Kudrya- } \\
\text { shov et al., 1991; Kudrya- } \\
\text { shov et al., 1993; Vasiliev et } \\
\text { al., 1993a; Kudryashov et al., } \\
1994\end{array}$} \\
\hline & & $30-89$ & $\begin{array}{l}\text { Electromechani- } \\
\text { cal drill KEMS- } \\
112\end{array}$ & \\
\hline \multirow[t]{2}{*}{1985} & $\begin{array}{l}\text { Vavilov Glacier } \\
\text { ( } 26 \mathrm{~km} \text { southwest of gla- } \\
\text { ciological station Kupol } \\
\text { Vavilova) }\end{array}$ & 102 & $\begin{array}{l}\text { Thermal drill } \\
\text { ETB-130 }\end{array}$ & Morev et al., 1988 \\
\hline & $\begin{array}{l}\text { Vavilov Glacier } \\
\text { (Kupol Vavilova) }\end{array}$ & 50 & $\begin{array}{l}\text { Thermal drill } \\
\text { PTBS-112 }\end{array}$ & Chistyakov et al., 1988 \\
\hline \multirow[b]{2}{*}{1986} & \multirow{2}{*}{$\begin{array}{l}\text { Vavilov Glacier } \\
\text { (Kupol Vavilova) }\end{array}$} & $0-36.9$ & $\begin{array}{l}\text { Thermal drill } \\
\text { TELGA-152M }\end{array}$ & \multirow{2}{*}{$\begin{array}{l}\text { Bobin et al., 1988; Kudrya- } \\
\text { shov et al., 1989; Kudrya- } \\
\text { shov et al., 1991; Kudrya- } \\
\text { shov et al., 1993; Vasiliev et } \\
\text { al., } 1993 a ; \text { Kudryashov et al., } \\
1994\end{array}$} \\
\hline & & $36.9-151.8$ & $\begin{array}{l}\text { Electromechani- } \\
\text { cal drill KEMS- } \\
112\end{array}$ & \\
\hline 1986 & \multirow[b]{2}{*}{$\begin{array}{l}\text { Akademiya Nauk Glacier } \\
\text { (\# AN1) }\end{array}$} & $\begin{array}{l}13 ; \\
0-561\end{array}$ & & \multirow{2}{*}{$\begin{array}{l}\text { Savatyugin and Zagorodnov, } \\
\text { 1987; } \\
\text { Klemet'ev et al., 1988; } \\
\text { Zagorodnov, 1989a; Zagorod- } \\
\text { nov, 1989b; Zagorodnov et } \\
\text { al., 1989c; Zagorodnov et al., } \\
\text { 1990b; Zagrodnov and Arkhi- } \\
\text { pov, 1990c }\end{array}$} \\
\hline 1987 & & $222-761$ & ATED ETB-3 & \\
\hline \multirow[b]{2}{*}{1988} & \multirow[b]{2}{*}{$\begin{array}{l}\text { Vavilov Glacier } \\
\text { (Kupol Vavilova) }\end{array}$} & $0-32.2$ & $\begin{array}{l}\text { Thermal drill } \\
\text { TELGA-152M }\end{array}$ & \multirow{2}{*}{$\begin{array}{l}\text { Bobin et al., 1988; Kudrya- } \\
\text { shov et al., 1989; Vasiliev et } \\
\text { al., 1989; Kudryashov et al., } \\
\text { 1991; Vasiliev and Talalay, } \\
\text { 1992; Kudryashov et al., } \\
\text { 1993; Vasiliev et al., 1993a; } \\
\text { Kudryashov et al., 1994; Bli- } \\
\text { nov et al., } 1994\end{array}$} \\
\hline & & $32.2-461.6$ & $\begin{array}{l}\text { Electromechani- } \\
\text { cal drill KEMS- } \\
112\end{array}$ & \\
\hline 1999 & Akademiya Nauk Glacier & $0-53.9$ & Electromechani- & Vasiliev et al., 2001; \\
\hline
\end{tabular}




\begin{tabular}{|l|l|l|l|l|}
\hline Year & $\begin{array}{l}\text { Site Location (Site } \\
\text { Number*) }\end{array}$ & $\begin{array}{l}\text { No. of holes,- } \\
\text { hole depth or } \\
\text { drilling interval, } \\
\mathrm{m}\end{array}$ & $\begin{array}{l}\text { Type of drilling } \\
\text { equipment }\end{array}$ & References \\
\hline 2000 & (\# AN2) & $53.9-504.7$ & $\begin{array}{l}\text { cal drill KEMS- } \\
132\end{array}$ & $\begin{array}{l}\text { Savatyugin et al., 2001; } \\
\text { Savatyugin and Shevnina, } \\
2003\end{array}$ \\
\cline { 3 - 5 } 2001 & & $504.7-724$ & & \\
\hline
\end{tabular}

*Site numbers see Fig. 10.

Table 10. IGAS thermal drilling on Spitsbergen.

\begin{tabular}{|c|c|c|c|c|}
\hline Year & $\begin{array}{l}\text { Site Location } \\
\text { (Site Number*) }\end{array}$ & $\begin{array}{l}\text { No. of holes, } \\
\text { hole depth or } \\
\text { drilling interval, } \\
m\end{array}$ & $\begin{array}{l}\text { Type of drilling } \\
\text { equipment }\end{array}$ & References \\
\hline \multirow{4}{*}{1975} & \multirow{3}{*}{$\begin{array}{l}\text { Ice-divide area between } \\
\text { East Grënfjord and } \\
\text { Fridtjof glaciers } \\
\text { (\# S1) }\end{array}$} & $\begin{array}{l}\text { Three shallow } \\
\text { holes }(8 ; 8 ; 15)\end{array}$ & $\begin{array}{l}\text { Thermo-electric } \\
\text { point Elektroigla } \\
\text { ETI-1 }\end{array}$ & \multirow{6}{*}{$\begin{array}{l}\text { Zagorodnov and Zotikov, } \\
\text { 1981a; } \\
\text { Zagorodnov and Samoilov, } \\
\text { 1982a; } \\
\text { Kotlyakov (ed.), } 1985\end{array}$} \\
\hline & & 201 & ATED ETB-3 & \\
\hline & & 201-211.1 & $\begin{array}{l}\text { Thermo-electric } \\
\text { point Elektroigla } \\
\text { ETI-1 }\end{array}$ & \\
\hline & $\begin{array}{l}\text { Vơring Glacier } \\
\text { (\# S2) }\end{array}$ & $\begin{array}{l}\text { Six shallow } \\
\text { holes }(15 ; 15 ; \\
12 ; 10 ; 40 ; 12)\end{array}$ & $\begin{array}{l}\text { Thermo-electric } \\
\text { point Elektroigla } \\
\text { ETI-1 }\end{array}$ & \\
\hline \multirow[b]{2}{*}{1976} & \multirow[b]{2}{*}{$\begin{array}{l}\text { Lomonosov Plateau } \\
\text { (\# S3) }\end{array}$} & 201 & ATED ETB-3 & \\
\hline & & 27 & $\begin{array}{l}\text { Thermo-electric } \\
\text { point Elektroigla } \\
\text { ETI-1 }\end{array}$ & \\
\hline \multirow{2}{*}{1979} & \multirow{2}{*}{$\begin{array}{l}\text { Fridtjof glacier } \\
\text { (\# S4) }\end{array}$} & $\begin{array}{l}\text { Three holes } \\
\text { (48; 114; 0- } \\
119)\end{array}$ & ATED ETB-3 & \multirow{2}{*}{$\begin{array}{l}\text { Zagorodnov et al., 1985; } \\
\text { Kotlyakov (ed.), } 1985\end{array}$} \\
\hline & & $119-220$ & $\begin{array}{l}\text { Thermo-electric } \\
\text { point Elektroigla } \\
\text { ETI-1 }\end{array}$ & \\
\hline \multirow{5}{*}{1980} & \multirow[t]{2}{*}{$\begin{array}{l}\text { Bertil Glacier } \\
\text { (\# S5) }\end{array}$} & $\begin{array}{l}\text { Three shallow } \\
\text { holes } \\
(108 ; 53 \text { and } 8)\end{array}$ & $\begin{array}{l}\text { Thermo-electric } \\
\text { point Elektroigla } \\
\text { ETI-1 }\end{array}$ & \multirow{5}{*}{$\begin{array}{l}\text { Zagorodnov, 1981; } \\
\text { Zagorodnov and Zotikov, } \\
\text { 1981b; } \\
\text { Zagorodnov and Samoilov, } \\
\text { 1982a; } \\
\text { Samoilov and Zagorodnov, } \\
\text { 1985; } \\
\text { Kotlyakov (ed.), 1985; } \\
\text { Zagorodnov, 1988; }\end{array}$} \\
\hline & & 7 & ATED ETB-3 & \\
\hline & $\begin{array}{l}\text { Bogger Glacier } \\
\text { (\# S6) }\end{array}$ & $\begin{array}{l}\text { Three shallow } \\
\text { holes }(8 ; 6 \text { and } \\
\text { 4) }\end{array}$ & $\begin{array}{l}\text { Thermo-electric } \\
\text { point Elektroigla } \\
\text { ETI-1 }\end{array}$ & \\
\hline & \multirow{2}{*}{$\begin{array}{l}\text { Amundsen Plateau } \\
\text { (\# S7) }\end{array}$} & $\begin{array}{l}\text { Two holes }(24 \\
\text { and } \\
386.5)\end{array}$ & ATED ETB-3 & \\
\hline & & $\begin{array}{l}386.5-586 \text { and } \\
\text { two shallow } \\
\text { holes (16 and } \\
12)\end{array}$ & $\begin{array}{l}\text { Thermo-electric } \\
\text { point Elektroigla } \\
\text { ETI-1 }\end{array}$ & \\
\hline
\end{tabular}




\begin{tabular}{|c|c|c|c|c|}
\hline Year & $\begin{array}{l}\text { Site Location } \\
\text { (Site Number*) }\end{array}$ & $\begin{array}{l}\text { No. of holes, } \\
\text { hole depth or } \\
\text { drilling interval, } \\
\mathrm{m}\end{array}$ & $\begin{array}{l}\text { Type of drilling } \\
\text { equipment }\end{array}$ & References \\
\hline \multirow{2}{*}{1981} & \multirow{2}{*}{$\begin{array}{l}\text { Vestfonna, Nordaust- } \\
\text { landet } \\
\text { (\# S8) }\end{array}$} & $\begin{array}{l}\text { Five holes (24; } \\
24 ; 25 ; 24 ; \\
208.2)\end{array}$ & ATED ETB-3 & \multirow{2}{*}{$\begin{array}{l}\text { Zagorodnov and Zinger, 1982; } \\
\text { Punning et al., 1985; } \\
\text { Kotlyakov (ed.), } 1985\end{array}$} \\
\hline & & $\begin{array}{l}\text { Three shallow } \\
\text { holes }(24 ; 20 ; \\
72)\end{array}$ & $\begin{array}{l}\text { Thermo-electric } \\
\text { point Elektroigla } \\
\text { ETI-1 }\end{array}$ & \\
\hline \multirow[t]{2}{*}{1982} & \multirow{2}{*}{$\begin{array}{l}\text { Lomonosov Plateau } \\
\text { (\# S9) }\end{array}$} & 35 & $\begin{array}{l}\text { Thermo-electric } \\
\text { point Elektroigla } \\
\text { ETI-1 }\end{array}$ & \multirow{2}{*}{$\begin{array}{l}\text { Zagorodnov et al., } 1984 ; \\
\text { Kotlyakov (ed.), } 1985\end{array}$} \\
\hline & & $31 ; 135$ & ATED ETB-3 & \\
\hline 1985 & $\begin{array}{l}\text { Austfonna, Nordaust- } \\
\text { landet } \\
\text { (\# S10) }\end{array}$ & $\begin{array}{l}32.4 \\
204.1 \\
53.7 \\
60.9\end{array}$ & ATED ETB-3 & $\begin{array}{l}\text { Anonymous author, 1986; } \\
\text { Arkhipov et al., 1987; } \\
\text { Zagorodnov, 1989b; } \\
\text { Zagorodnov, 1989c; } \\
\text { Zagorodnov et al., 1990a; } \\
\text { Zagrodnov and Arkhipov, } \\
\text { 1990c }\end{array}$ \\
\hline 1987 & $\begin{array}{l}\text { Austfonna, Nordaust- } \\
\text { landet } \\
\text { (\# S11) }\end{array}$ & 566.7 & ATED ETB-3 & $\begin{array}{l}\text { Zagorodnov et al., 1988; } \\
\text { Zagorodnov, 1989b; } \\
\text { Zagorodnov, 1989c; } \\
\text { Zagorodnov et al., 1990a; } \\
\text { Zagrodnov and Arkhipov, } \\
\text { 1990c }\end{array}$ \\
\hline
\end{tabular}

*See site numbers Fig. 11.

\section{5-1960: Franz-Josef Land, Novaya Zemlya, Polar Urals, Tien Shan}

During this time, specialists of IGAS carried out major temperature surveys of polar and mountain glaciers (Tsykin 1962, 1963a,b,c). For drilling to depths of $30 \mathrm{~m}$, a special set of hand drilling equipment was designed by E.N. Tsykin. This set included a core barrel, aluminum rods with bayonet or hinged joints, a manual T-handle driver, and a tripod mast. The core barrel was made from carbon steel tubing with long slots (Fig. 19). On the lower part of the barrel were two teeth of different height. One higher straight tooth was designed for cutting and a second one with a curved configuration directed the ice chips inside the barrel.

Three nominal sizes of core barrels with different lengths and outside diameters (OD) were designed:

- 1-m length with an OD of $58 \mathrm{~mm}$ for drilling to depths of $30 \mathrm{~m}$. 
- $0.75-\mathrm{m}$ length with an OD of $52 \mathrm{~mm}$ for drilling to depths of $15 \mathrm{~m}$.

- 0.5 -m length with an OD of $46 \mathrm{~mm}$ for drilling to depths of $8 \mathrm{~m}$.
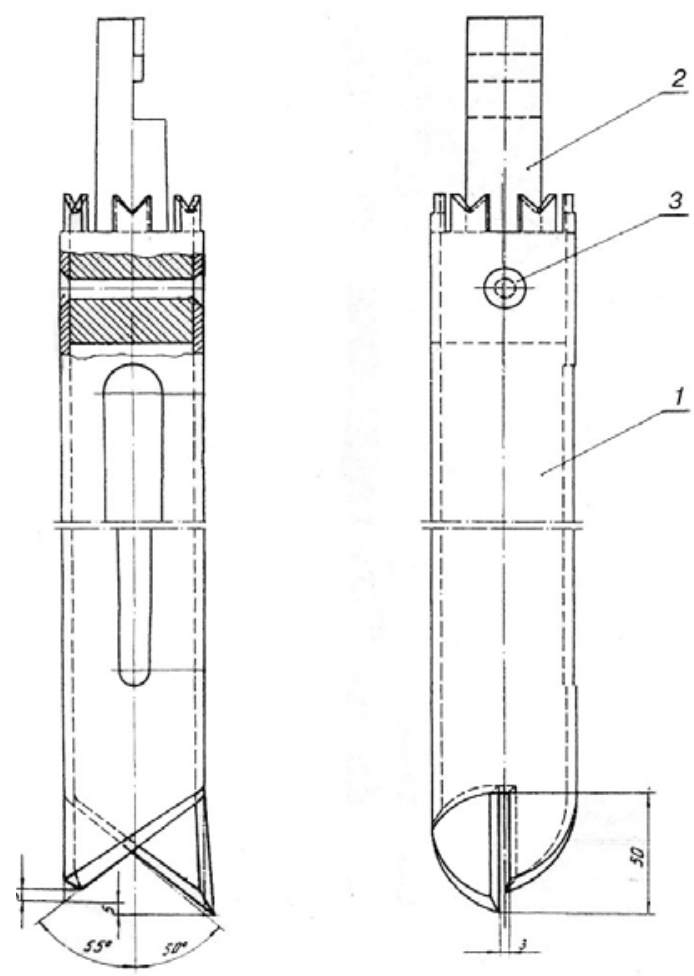

Figure 19. Core barrel of Tsykin's hand ice drill (from Tsykin 1963c).

The material recovered inside the core barrel was represented by ice clumps intermixed with chips. Normally the meter-length core barrel was totally filled after a penetration of $0.5-0.6 \mathrm{~m}$ in cold ice. In temperate ice the length of run dropped to $0.25^{-0.3} \mathrm{~m}$. As mentioned, above aluminum rods with bayonet or hinged joints were used. Use of these rods eliminated the need for a mast. In this case the drill was hoisted from the hole strictly by hand and the drill string was laid down directly on the surface without uncoupling. The hinged joints allowed deflecting the drill string to an angle of $120^{\circ}$.

From 1955 to 1960 more than a hundred shallow holes were drilled by Tsykin's drill (Table 7). The drilling was quite effective. For example, the drilling of a 25-m deep hole in the Polar Urals by a team of four-people took 9 working hours. 
From 1957-1959 the modified Tsykin drill was used by an expedition of the Geography Department of the Academy of Sciences of Kazakh SSR (Vilesov and Shabanov 1961; Tsykina and Vilesov 1963). Eleven holes with a total cumulative depth of $250 \mathrm{~m}$ were drilled on Central Tuiuksu and Igly-Tuiuksu glaciers (Northern Tien Shan). The deepest hole, of $52.65 \mathrm{~m}$, reached bedrock beneath the glacier. The drilling of this hole took 96 hours.

\section{8-1959: Churlyenis Glacier (Franz Josef Land)}

Franz Josef Land archipelago is a compact group of 191 islands between $79^{\circ} 46^{\prime}-81^{\circ} 52^{\prime} \mathrm{N}$ and $44^{\circ} 52^{\prime}-65^{\circ} 25^{\prime} \mathrm{E}$ with $85.1 \%$ of its area covered by glaciers. The Churlyenis ice cap has an area of $444 \mathrm{~km}^{2}$ and covers $87.4 \%$ of Guker Island $\left(80^{\circ} 09^{\prime}-80^{\circ} 25^{\prime} \mathrm{N}\right.$ and $\left.52^{\circ} \mathrm{O}^{\prime}-53^{\circ} 5 \mathrm{O}^{\prime} \mathrm{E}\right)$ in the central section of Franz Joseph Land. The highest altitude of the Churlyenis ice cap is $445 \mathrm{~m}$ above sea level (a.s.l.). In the summer seasons of 1958 and 1959, a few holes with depths from 20 to $82 \mathrm{~m}$ were drilled using a conventional SBU-150-ZIV type self-propelled drilling rig in the central part and edges of the ice cap (Fig. 20). The field operations were carried out by a Glaciological Expedition of IGAS. The drilling reached bedrock beneath the glacier and stopped after penetrating 1.5-2 m into sub-glacial rocks. The cuttings were removed by the circulation of compressed air produced by a stationary VK-3-5 single-stage compressor with a working pressure of 0.4 $\mathrm{MPa}$ at an output of $0.8-1.2 \mathrm{~m}^{3} / \mathrm{min}$. The main part of the ice chips were collected in a 4-m length sedimentation barrel placed above the core barrel. The conventional carbide-insert drill bits were ineffective for ice cutting because of their small clearances. The most effective bits were homemade, six teeth steel bits. The height of the teeth was 20-35 mm (for different bits) and their wedge or rake angles were correspondingly 67$55^{\circ}$. On several occasions, the air condensate froze on the borehole wall resulting in a stuck drill. Drill recovery consisted of dropping $3-5 \mathrm{~kg}$ portions of table salt into the hole and waiting 2-10 hours before the drill was free. The average penetration rates depended upon the speed of drill rotation and were $15 \mathrm{~m} / \mathrm{h}$ at $72 \mathrm{rpm}, 20 \mathrm{~m} / \mathrm{h}$ at $113 \mathrm{rpm}$ and $27 \mathrm{~m} / \mathrm{h}$ at 180 $\mathrm{rpm}$. The optimum length of run was found to be in the range of 1-1.5 m. The core was usually broken in pieces with lengths of $0.2-0.8 \mathrm{~m}$. The average core recovery was $70-80 \%$. The temperature measurements were carried out in the 8o-m-deep hole situated on the west flank of the ice cap, $2 \mathrm{~km}$ from its center (Zotikov and Razumeiko 1966). An inverse temperature gradient of nearly $-0.013^{\circ} \mathrm{C} / \mathrm{m}$ was found and the hole temperature decreased uniformly from $-11^{\circ} \mathrm{C}$ at a depth of $20 \mathrm{~m}$ to $-11.8^{\circ} \mathrm{C}$ at the bot- 
tom. Grosvald et al. (1973) gave temperature records for three holes. Two of them with depths of 15 and $50 \mathrm{~m}$ were drilled near the top of Churlyenis Glacier at an altitude of $354 \mathrm{~m}$ a.s.l. The third hole with a depth of $15 \mathrm{~m}$ was drilled in the ablation zone at an altitude of $65 \mathrm{~m}$ a.s.l. In the 50-mdeep hole at depths of $15-30 \mathrm{~m}$, the temperature decreased with a gradient of $0.02-0.04^{\circ} \mathrm{C} / \mathrm{m}$. At a depth of $30-40 \mathrm{~m}$, the temperature was constant and equal to about $10.1^{\circ} \mathrm{C}$. At depths deeper than $40 \mathrm{~m}$, the temperature decreased again with a gradient of $0.01-0.02^{\circ} / \mathrm{m}$.

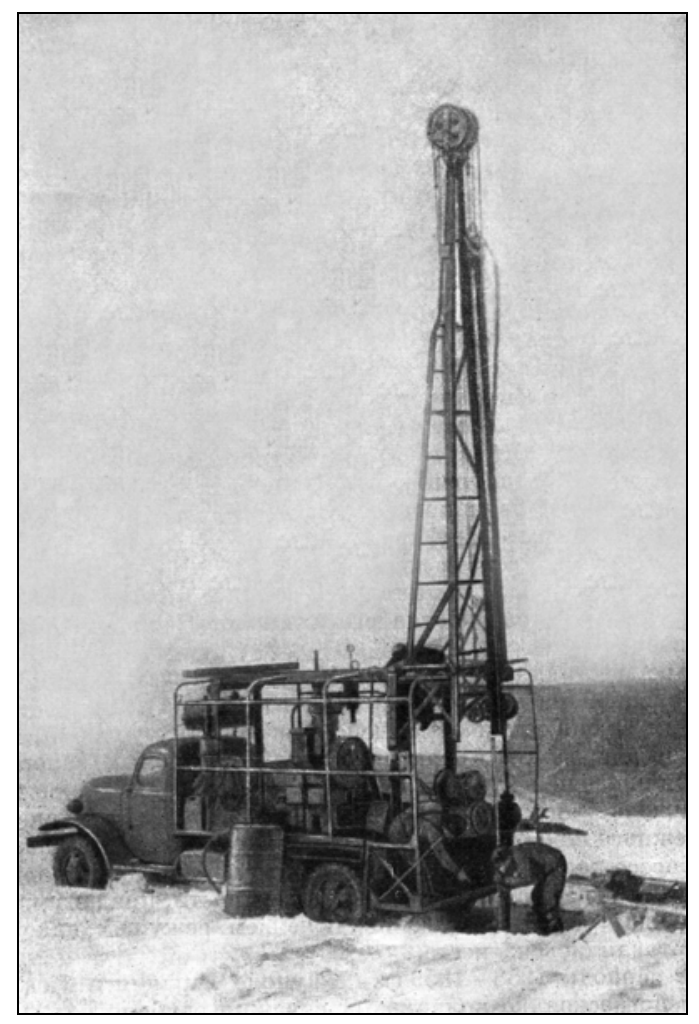

Figure 20. Drilling operations on Churlyenis Glacier, Franz Josef Land, 1958-1959 (photograph by M.Grosvald, from Bazanov 1961).

\section{3: Elbrus (Central Caucasus, drilling site \#C1*)}

The glacier complex of Elbrus Massif is the largest in the Caucasus, with a total area of $122.6 \mathrm{~km}^{2}$ (Fig. 21). The large ice cap covers the central part of Elbrus and recharges 10 glacial flows. The drilling team of IGAS (V.G. Golovnya, V.V. Kurganov, and E.N. Tsykin) carried out the first experiments with a cable-suspended percussion drilling rig in the area of the

\footnotetext{
* see map Fig. 21 and Table 7.
} 
Moscow State University station Ledovaya Basa (Tsykin 1966). This rig consisted of a drive tube (Fig. 22), tripod mast, and winch, with a 4-mmdiameter steel cable. The winch was driven by a $2.2-\mathrm{kW}$ gasoline powered motor. The travel distance of the hammer was nearly $1 \mathrm{~m}$; its weight was 20-40 kg depending on the inner diameter of the drive tube. The first drive tube was manufactured from high-alloy steel tubing with an ID/OD of $67 / 70 \mathrm{~mm}$. The total weight of the rig was near $300 \mathrm{~kg}$. After each blow, the drive tube penetrated into the ice a few centimeters, and normally 20 blows were enough to penetrate the $0.5 \mathrm{~m}$ length of the drive tube. The recovered ice was crushed into fine pieces with one or two larger clumps near $50 \mathrm{~mm}$ in size. A total of six holes from 28 to $40 \mathrm{~m}$ were drilled. The drilling of two holes was terminated as water appeared in the holes. Other holes were stopped because of a sticking drive tube.

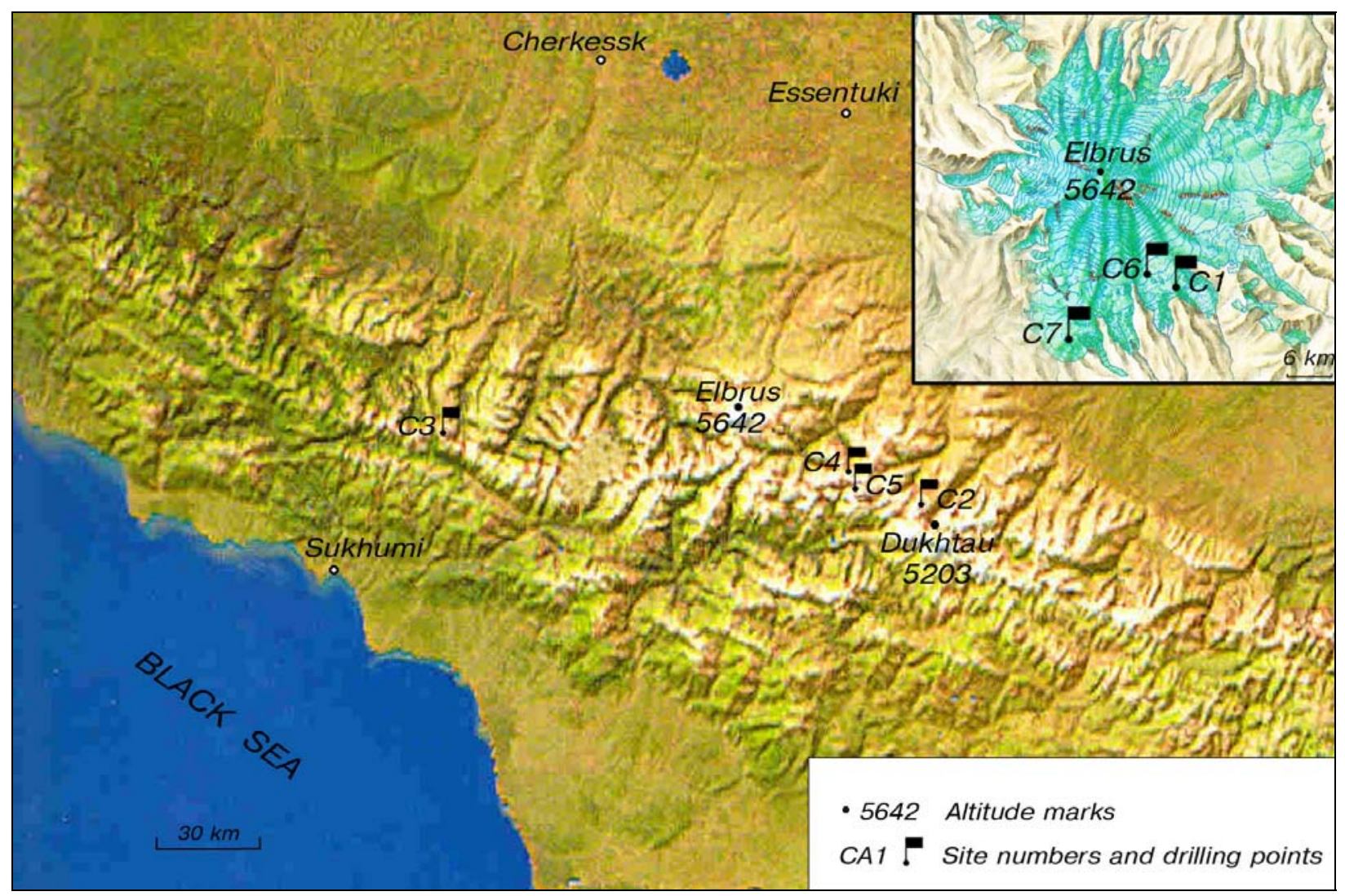

Figure 21. Caucuses and locations of drilling sites. 


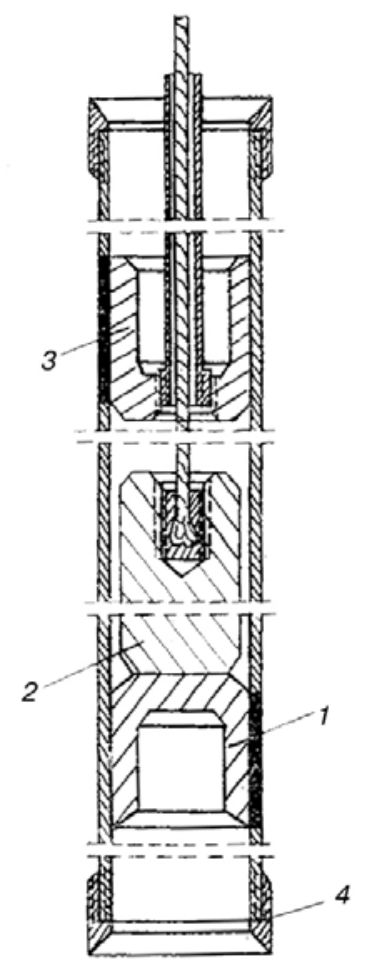

Figure 22. Drive tube of the cable-percussion drilling rig: (1) steel lower plug; (2) hammer; (3) steel upper plug; (4) dismountable shoe (from Tsykin 1966 and 1970).

\section{4: Tuiuksu Glacier (Zailiiskii Alatau, Northern Tien Shan, drilling site \#CA1)*}

The mountain-glacier basin Tuiuksu is situated on the northern flank of the Zailiiskii Alatau Ridge (Northern Tien Shan) and consists of 10 glaciers of different morphologic types. The main investigations were carried out on the Central Tuiuksu Glacier (usually called simply Tuiuksu Glacier). The area of this glacier is $3.8 \mathrm{~km}^{2}$; its length is $3.8 \mathrm{~km}$, the altitude of the glacier edge is $3400 \mathrm{~m}$ a.s.l., the thickness in the middle area is $50-80 \mathrm{~m}$, and the average rate of movement is $22.3 \mathrm{~m}$ per year. In 1964 a jet-fire drill designed by the Kazakh Polytechnic Institute (Alama-Ata, Kazakhstan) was used for penetrating the Tuiuksu_Glacier (Brichkin et al. 1967). The rocket-type burner weighed 3-4 kg and was connected to flexible pressure hose; it was hoisted in the hole with a steel cable and hand winch (Fig. 24). The pressure hose were fixed to the steel cable at 2-m intervals. The kerosene and oxygen were discharged to the burner at pressures of 1.1-1.2 MPa and 1.0-1.1 MPa respectively. Two holes were drilled to depths of 33 and $23 \mathrm{~m}$. The diameter of the first hole was $120-130 \mathrm{~mm}$,

\footnotetext{
* see map Fig. 23 and Table 7.
} 
and its drilling took 28 minutes (average rate of penetration was $71 \mathrm{~m} / \mathrm{h}$ ). The diameter of the second hole was 140-150 mm, and its drilling took 26 minutes (average rate of penetration was $53 \mathrm{~m} / \mathrm{h}$ ).

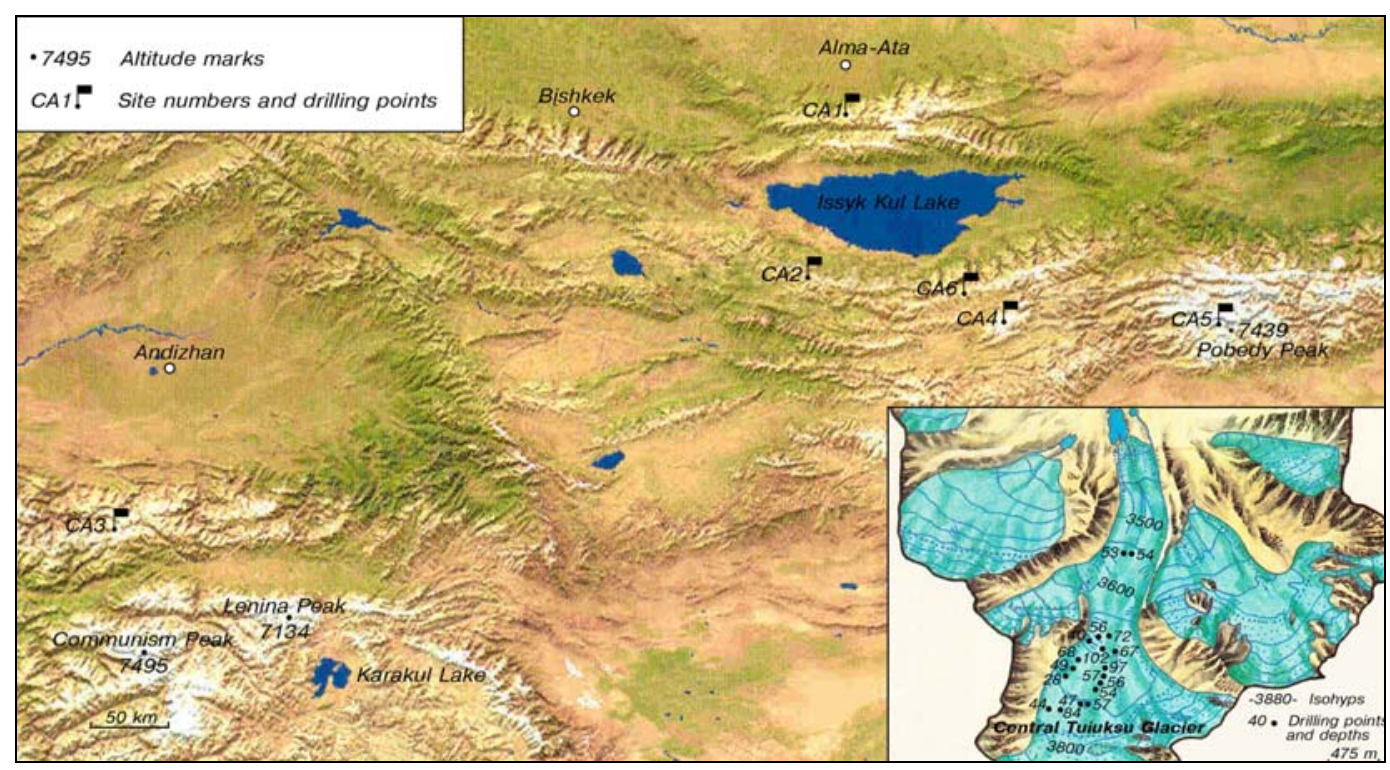

Figure 23. Central Asia and location of drilling sites.

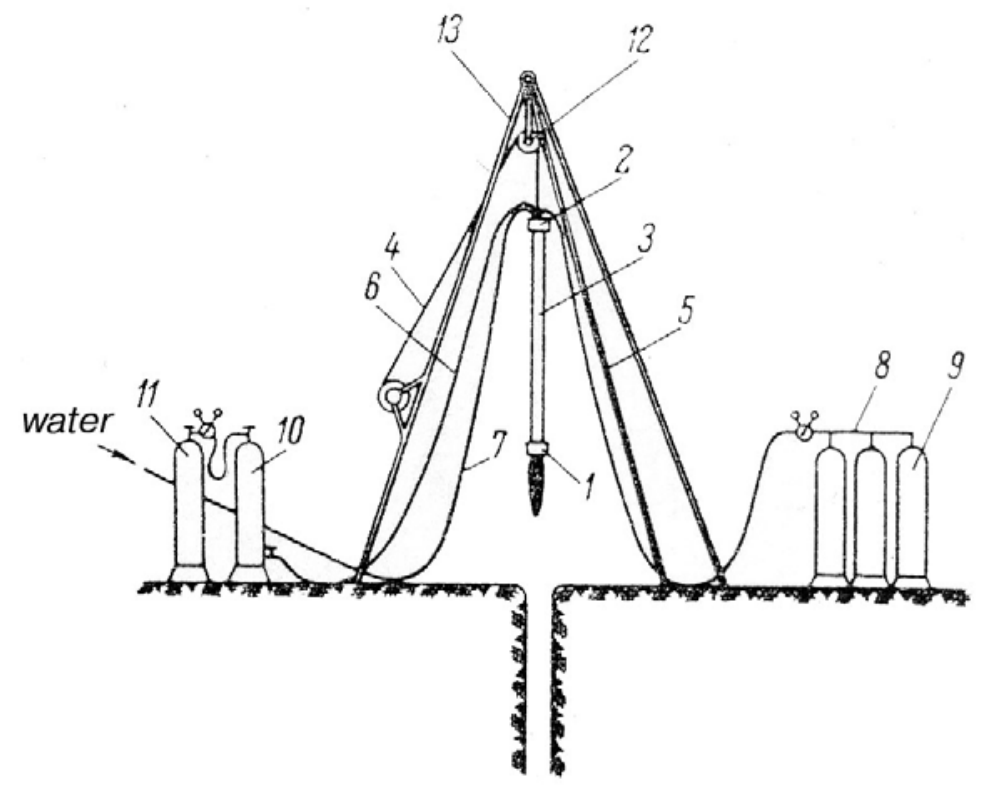

Figure 24. Jet-fire drill: (1) burner; (2) distributor head; (3) body; (4) steel cable; (5) oxygen pressure pipe; (6) kerosene pressure pipe; (7) water pipe; (8) oxygen manifold; (9) oxygen containers; (10), (11) kerosene containers; (12) wheel; (13) tripod mast (from Brichkin et al. 1967). 


\section{5}

\section{Noredenskiöld Glacier (Spitsbergen)}

Archipelago Spitsbergen (Svalbard) is part of, but not exclusively under the sovereignity of, Norway and is situated in the Arctic Ocean between Greenland and the Barents seas. Glaciers occupy $34,800 \mathrm{~km}^{2}$ or nearly $58 \%$ of the archipelago area. Soviet investigations of Spitsbergen glaciers started in 1965 when the Spitsbergen Glaciological Expedition of IGAS was founded (Koryakin 1981). In 1965 a few holes were drilled in the central part of the Noredenskiöld Glacier using hand operated mechanical drilling equipment. The deepest hole was $25 \mathrm{~m}$. The actual depth of this hole was closer to $11 \mathrm{~m}$ because it was drilled from the bottom of a $14 \mathrm{~m}$ snow pit (Troitskii et al. 1975) The temperatures below $16 \mathrm{~m}$ were nearly constant at around $-1^{\circ} \mathrm{C}$.

\section{Karabatkak Glacier (Terskei Alatau, Internal Tien Shan, drilling site \#CA2)*}

Terskei Alatau is a high ridge bordered on the south by Issyk Kul Lake (East Kyrgyzstan). The length of Terskei Alatau is $380 \mathrm{~km}$, and the average altitude is $4000 \times 4200 \mathrm{~m}$ (highest peak is $5216 \mathrm{~m}$ a.s.l.). About 1375 glaciers are situated on Terskei Alatau with a total area of $1123.7 \mathrm{~km}^{2}$ (Dolgushin and Osipova 1989). Karabatkak Glacier is situated on the northern slope of Terskei Alatau in the upper reaches of the Chon-Kyzyl-Suu River. The length of the glacier is $3.5 \mathrm{~km}$, its area is $4.5 \mathrm{~km}^{2}$, and the average thickness is $50-80 \mathrm{~m}$. The systematic observations on Karabatkak Glacier were started in 1947 by the staff of the Tien Shan Physiographic Station. In 1966 the experiments with a cable-percussion drilling rig were continued on Karabatkak Glacier by IGAS specialists: V.V. Kurganov, E.N. Tsykin, G.A. Tsykina, and V.A. Shmyrov (Tsykin 1966). The design of the rig was modified; in particular, the drive tube was strengthened. The ID/OD of the tube was $81 / 85 \mathrm{~mm}$. The power of the drive motor was increased to 5.9 $\mathrm{kW}$. The drilling process was improved by using a special detachable shoe (see item 4 on Fig. 22), which fit freely on the lower end of the drive tube. At the end of the run, the shoe remained in the hole bottom when the drive tube was hoisted to the surface. It prevented the drive tube from sticking and strengthened the impact end. After recovering the ice material, the drive tube was lowered to the bottom of the hole and a slight chamfer on the top end of the shoe allowed it to nest inside the shoe. After drilling was

\footnotetext{
* see map Fig. 23 and Table 7.
} 
terminated, the shoe was not recovered from the hole. A 49-m-deep hole was drilled by this modified cable-percussion drilling rig with an average penetration rate of $5^{-6} \mathrm{~m} / \mathrm{h}$. The fuel consumption of the drive motor was $0.1 \mathrm{~L} / \mathrm{m}$.

\section{6: Bezengi Glacier (West Caucasus, drilling site \#C2)*}

In the summer of 1966 the tests of a cable-suspended percussion drilling rig were continued again by an IGAS team on Bezengi Glacier (Psar'eva et al. 1968; Tsykin 1970). This glacier is one of the largest in the Caucasus, with a length of more than $17 \mathrm{~km}$ and an area of nearly $36 \mathrm{~km}^{2}$. The maximum glacier thickness at the edge is $250-300 \mathrm{~m}$. The total weight of the drilling rig was $460 \mathrm{~kg}$, including the drilling machine, which weighed 200 $\mathrm{kg}$, a tripod mast of $150 \mathrm{~kg}$, the drill of $60 \mathrm{~kg}$, and a steel cable of $50 \mathrm{~kg}$. At first a few holes with depths less than $100 \mathrm{~m}$ were drilled. In all cases drilling was terminated when water appeared in the hole or the hole reached the glacier bed. Finally, the deepest hole, $150-\mathrm{m}$, was drilled $7 \mathrm{~km}$ from the glacier edge at an altitude of $2700 \mathrm{~m}$ a.s.l. Drilling was carried out over four days (26 working hours). The average rate of penetration was 5.8 $\mathrm{m} / \mathrm{h}$. At the bottom of the 150-m hole, the drill became stuck after encountering a boulder. The temperature distribution in the hole was unusual. From the surface the temperature decreased uniformly to $-0.6^{\circ} \mathrm{C}$ at a depth of $10 \mathrm{~m}$, below which it increased to $0.0^{\circ} \mathrm{C}$ at $80 \mathrm{~m}$ and remained unchanged to the hole bottom.

\section{7: Marukh Glacier (West Caucasus, drilling site \#C3)†)}

Marukh Glacier is a typical Caucasian valley glacier and is situated in the region of the Marukha riverhead (Krenke et al. 1988). It has a length of 4 $\mathrm{km}$ and an area of $3.3 \mathrm{~km}^{2}$. The highest altitude of Marukh Glacier is 3160 $m$ a.s.l. and it drops down to 2490 m a.s.l. In 1967-1982 the regular glaciological investigations of Marukh Glacier were carried out by specialists of the IGAS and the North-Caucasian Division of the HydroMeteorological Service. In July-August of 1967, in the upper part of the Marukh Glacier, three holes were drilled by a cable-suspended percussion rig (Tsykin 1970; Bazheva and Krenke 1970; Bazheva and Psar'eva 1973). The first hole was drilled to $45 \mathrm{~m}$, where a thick aqueous layer was encountered, which terminated drilling in this hole. A similar scenario occurred in

\footnotetext{
* see map Fig. 21 and Table 7.

† see map Fig. 21 and Table 7.
} 
the second hole at $50 \mathrm{~m}$. The third hole was drilled down to debriscontaining ice at $78 \mathrm{~m}$.

\section{9}

\section{Marukh Glacier (West Caucasus, drilling site \#C3) ${ }^{*}$}

L.A Sukhanov and I.A. Zotikov carried out the first experiments with thermo-electric points on the edge of the northern part of Marukh Glacier (Sukhanov et al. 1974). During drilling at a depth of $20 \mathrm{~m}$, near the bed, a cavity filled by pressurized water was uncovered. The thermo-electric point dropped $2 \mathrm{~m}$ and penetration stopped. A short fountain of sandy water spurted out of the hole.

\section{Tuiuksu Glacier (Zailiiskii Alatau, Northern Tien Shan, drilling site \#CA1)†}

Drilling with a jet-fire drill started in 1964 and were continued by members of the Kazakh Polytechnic Institute in cooperation with the Geography Department of the Academy of Sciences of Kazakh SSR (Mikheev 1971). The new, modified drill was tested in August 1969. To decrease the weight of the drilling equipment, the oxidizing component was changed from oxygen to air, thus eliminating the need to deliver heavy oxygen cylinders to high-mountain regions. The air was provided by a modified compressor of the EK7A type with a nominal pressure of $0.8 \mathrm{MPa}$ at an output of $0.62 \mathrm{~m}^{3} / \mathrm{min}$. The total weight of the drilling equipment was $600 \mathrm{~kg}$. The new 4-m-long burner of the VTBM-4 type was equipped with a special automatic check valve that ensured the optimum mixing ratio of the components. The 12-L fuel tank was installed inside the upper part of the burner. On the lower end of the burner, an electronic bottom sensing gauge was attached. Four holes to depths of 28, 53.5, 72 and $53 \mathrm{~m}$ were drilled. The hole diameters were approximately $140 \mathrm{~mm}$ near the mouth and $80 \mathrm{~mm}$ at the bottom. The drilling time was 3.25 hours for the $53.5-\mathrm{m}$ deep hole and 5.55 hours for the 72-m deep hole. The average fuel consumption was $0.15^{-0.17} \mathrm{~L} / \mathrm{m}$. In the early 1970 's, jet-fire drilling on Tuiuksu Glacier was continued (Fig. 25). A total of nearly 20 holes down to bedrock were drilled. The drilling sites and final depths are shown in Figure 23 (Makarevich et al. 1984). The deepest hole was $102 \mathrm{~m}$ deep. The exact years of drilling were not reported.

\footnotetext{
* see map Fig. 21 and Table 7.

† see map Fig. 23 and Table 7.
} 


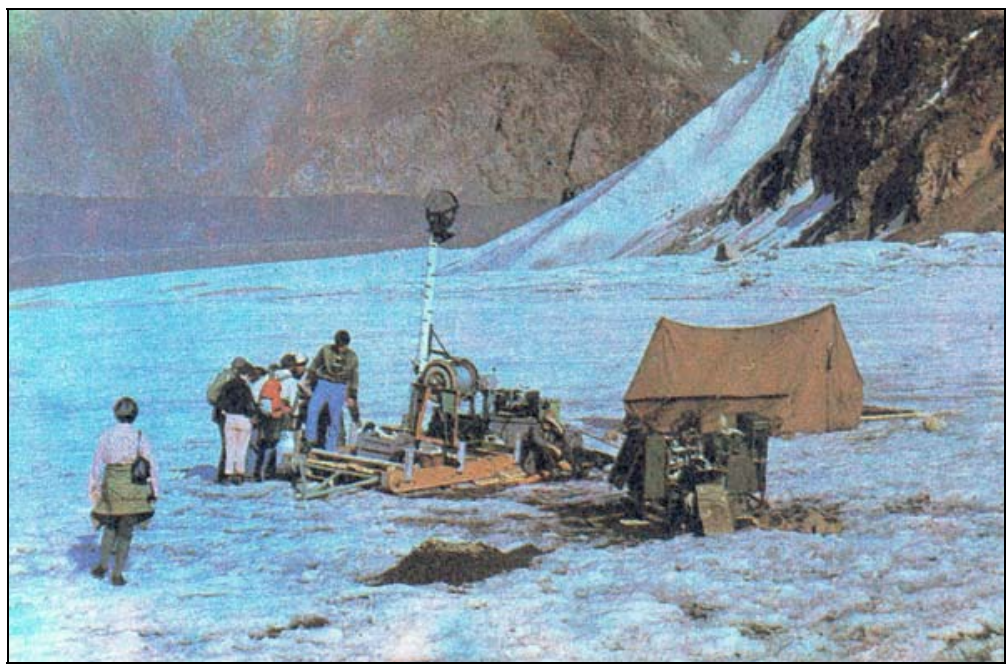

Figure 25. Jet-fire drilling on Tuiuksu Glacier, Northern Tien Shan (photograph by L.D. Dolgushin, from Dolgushin and Osipova 1989).

\section{0, 1971: Jankuat Glacier (Central Caucasus, drilling site \#C4 )*}

Jankuat Glacier is one of 742 glaciers on the north slope of the Central Caucasus and belongs to a representative type of mountain glacier having small glaciation areas (Golubev et al. 1978). The length of the glacier is 3.2 $\mathrm{km}$, its area is $3 \mathrm{~km}^{2}$ and the maximum thickness is nearly $120 \mathrm{~m}$. Jankuat Glacier begins from the ridge of the main Caucasus Range at an altitude of nearly $4000 \mathrm{~m}$ a.s.l. and drops down to $2700 \mathrm{~m}$ a.s.l. An integrated glaciological study of this glacier had been started in 1965. At the beginning of the 70s, to estimate the glacier thickness, 17 full diameter (no core) holes, including seven holes to bedrock, were drilled by thermal electric hot points (Fig. 26) designed by V.A. Morev (Elektroigla ETI-1) and L.A. Sukhanov (Mikroteb-1). The drilling was carried out by members of the Basic Research Laboratory of Snow Slides and Debris Flows (Geographical Department, Moscow State University).

Authors (Sukhanov 1973; Sukhanov et al. 1974; Golubev et al. 1976) reported the drilling of five holes with a total cumulative depth of $405 \mathrm{~m}$ using a thermo-electric point ETI-1 in 1970 and 1971. The deepest hole, 111 $\mathrm{m}$, reached bedrock (Golubev et al. [1976] reported about a 113-m deep hole). As there was no water removal, the speed of penetration gradually decreased from $10-13 \mathrm{~m} / \mathrm{h}$ in the near-surface permeable firn zone to $5^{-6}$ $\mathrm{m} / \mathrm{h}$ in pure ice below $17-20 \mathrm{~m}$. In the interval near-the bed, the penetration rate dropped to $2-3 \mathrm{~m} / \mathrm{h}$ owing to debris in the ice.

\footnotetext{
* see map Fig. 21 and Table 7.
} 


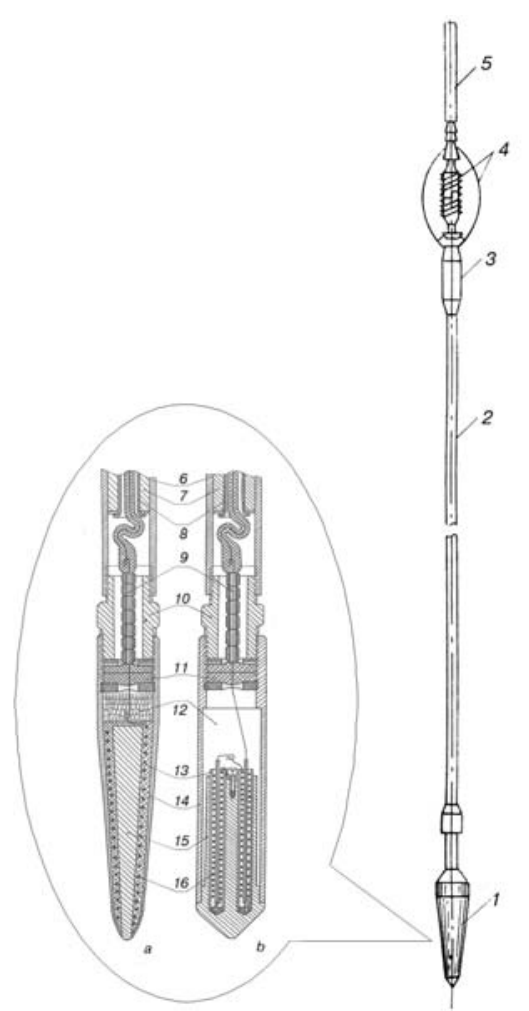

Figure 26. Thermo-electric points (a) Elektroigla ETI-1 and (b) Mikroteb-1: (1) thermal drill head; (2) rod; (3) cable termination; (4) centralizer; (5) cable; (6) lower end of the rod; (7) plug; (8) tube; (9) steel current lead; (10) adaptor; (11) sealing gasket; (12) heat-insulation (asbestos packing); (13) electrical insulation (silicone lacquer); (14) body of thermal drill head; (15) copper heat conductor; (16) nichrome wire (from Sukhanov et al. 1974; Morev 1976).

\section{1: Abramov Glacier (Alai Ridge, Pamirs, drilling site \#CA3)*}

Abramov Glacier is one of 477 glaciers on the south slope of the Alai Ridge (Pamirs-Alai Range, South Kyrgyzstan) and is situated at the head of the Kyzyl-Suu river (Suslov et al. 1980). The length of Abramov Glacier is nearly $9 \mathrm{~km}$ and its area is $25.2 \mathrm{~km}^{2}$. Abramov Glacier drops from an altitude of 4400 to $3620 \mathrm{~m}$ a.s.l. Since 1967, regular glaciological observations were carried out and an all-winter glaciological station was established on the upper part of the glacier. At the beginning of the 70s, the glacier thickness and ice structure were researched using thermal drilling equipment constructed by V.A. Morev. Members of SARNIGMI (Middle-East Regional Research Hydro-Meteorological Institute, Tashkent) carried out the drilling in cooperation with the AARI. Ruymin et al. (1974) reported on two holes drilled by a thermo-electric point in August and September of 1971 at the upper part of Abramov Glacier. Morev (1976) reported on doz- 
ens of holes drilled by the hot point ETI-1 in the Pamirs-Alai region in the beginning of the 7os. The total cumulative depth of these holes was nearly $1500 \mathrm{~m}$, with the deepest hole being $172 \mathrm{~m}$. The mean penetration rate was $7-11 \mathrm{~m} / \mathrm{h}$ at a drill head power of $1.5 \mathrm{~kW}$.

\section{2}

\section{Abramov Glacier (Alai Ridge, Pamirs, drilling site \#CA3)*}

In July of 1972, the drilling operations on Abramov Glacier were continued (Ryumin et al. 1974). V.A. Morev and L.M. Savatyugin drilled two holes to test a new thermal coring drill LKTBM-1, with no provision for removing or dissolving of the melted water. This is similar to the ETB-1 drill (Fig. 8a) described in (Morev et al. 1984). The deepest hole with core recovery reached bedrock at a depth of $113 \mathrm{~m}$.

In September of 1972 three holes with depths of 133.8, 166 and $151 \mathrm{~m}$ were drilled by specialists of SARNIGMI (V.K. Nozdryukhin and A.K. Ryumin) using a ETI-1 hot point (Ryumin et al. 1974). (Sukhanov et al. [1974] reported the drilling in 1972 on Abramov Glacier of a few holes by a thermoelectric point ETI-1 having a total cumulative depth of $375 \mathrm{~m}$ with the deepest hole being $175 \mathrm{~m}$.)

\section{Jankuat Glacier (Central Caucasus, drilling site \#C4 )†}

A few holes with a total cumulative depth of $160 \mathrm{~m}$ were drilled by a thermal electric hot point Mikroteb-1 (Sukhanov et al. 1974; Golubev et al. 1976). In the course of drilling the deepest hole, a cavity was found in the interval of $43-51 \mathrm{~m}$ where the hot-point penetrated rapidly for a short while then stopped. This hole $(51 \mathrm{~m})$ was the deepest of the season. A micro-caliper suitable for use in a $25-\mathrm{mm}$ borehole was also developed (Zagorodnov, personal communication).

\section{Drifting station Severnyi Polyus-19 (ice island in the Arctic Ocean)}

Dozens of holes were drilled by a ETI-1 hot point for a total cumulative depth of nearly $300 \mathrm{~m}$, with a maximum depth of $34 \mathrm{~m}$, and by an antifreeze thermal electric coring drill ATED for a total cumulative depth of 45 $\mathrm{m}$, with a maximum depth of $34 \mathrm{~m}$ (Morev 1976). In the latter case, the di-

\footnotetext{
* see map Fig. 23 and Table 7.

† see map Fig. 21 and Table 7.
} 
luted anti-freeze solution remains in the hole. I.A. Zotikov, N.N. Er'emin, A.P. Legen'kov, and V.A. Morev made the long-term temperature observations in the holes drilled through the ice island (Legen'kov et al. 1974). The temperature increased rather quickly from $-9.1 /-9.9^{\circ} \mathrm{C}$ at $13 \mathrm{~m}$ to $-1.8^{\circ} \mathrm{C}$ at the lower surface of the ice island (Legen'kov et al. [1974] reported the thickness of the ice island to be about $32.5 \mathrm{~m}$ ).

\section{3}

\section{Abramov Glacier (Alai Ridge, Pamirs, drilling site \#CA3)*}

In September of 1973 a 50.7-m hole was drilled in the firn zone of the Abramov Glacier using a thermal coring drill (Kislov and Nosdryukhin 1975). It took 47 runs to reach this depth. The average core diameter was $83.2 \mathrm{~mm}$.

Morev (1976) reported a few holes drilled by an anti-freeze thermal core drill in the Pamirs-Alai region at the beginning of the 7os. The exact date of drilling isn't reported. In total $300 \mathrm{~m}$ were drilled with an ATED (maximum depth was $137 \mathrm{~m}$ ). The mean rate of penetration by the ATED was $2.5-3.5 \mathrm{~m} / \mathrm{h}$ at a drill head power of $1.0-2.5 \mathrm{~kW}$.

\section{Jankuat Glacier (Central Caucasus, drilling site \#C4 $)^{\dagger}$}

Drilling operations were continued and a few holes were drilled by a thermal hot point (Golubev et al. 1976). Two holes with depths of 71 and $54 \mathrm{~m}$ reached bedrock beneath the glacier. The rate of penetration in pure ice was $5.5-7 \mathrm{~m} / \mathrm{h}$ and then rapidly decreased to $1-1.5 \mathrm{~m} / \mathrm{h}$ in the lower debris-containing ice near bedrock. The plot of penetration rate versus depth with straight line and exponential curve approximations was used to define the firn-ice transition and to study the inner structure of Jankuat Glacier.

\section{3, 1974}

\section{Obruchev Glacier (Polar Urals)}

Obruchev Glacier is a corrie glacier typical of most of the 91 glaciers in the Polar Urals. It has a length of nearly $750 \mathrm{~m}$ and maximum thickness of ap-

\footnotetext{
* see map Fig. 23 and Table 7.

† see map Fig. 21 and Table 7.
} 
proximately $140 \mathrm{~m}$. In 1973-1974, specialists of IGAS put together a research project aimed at determining the thickness of the Obruchev Glacier and to obtain samples for isotopic analysis of the ice (Morev 1976;

Zagorodnov et al. 1976). They drilled 28 holes having a total cumulative depth of $1426 \mathrm{~m}$ (maximum depth $137 \mathrm{~m}$ ) with a ETI-1 hot point. Eleven holes were drilled down to bedrock. Other holes penetrated only the upper 20-30 m. A special recorder registered the penetration rate in order to obtain the data on the density changes in the upper part of the glacier and to determine the firn-ice transition (Fig. 27). One of the holes was drilled by an anti-freeze thermal core drill to a depth of $86 \mathrm{~m}$ with core recovery of $98 \%$. In the latter case the drilling operation took only 4 days. The rate of penetration was $3.5^{-4} \mathrm{~m} / \mathrm{h}$ at a drill head power of $2 \mathrm{~kW}$.

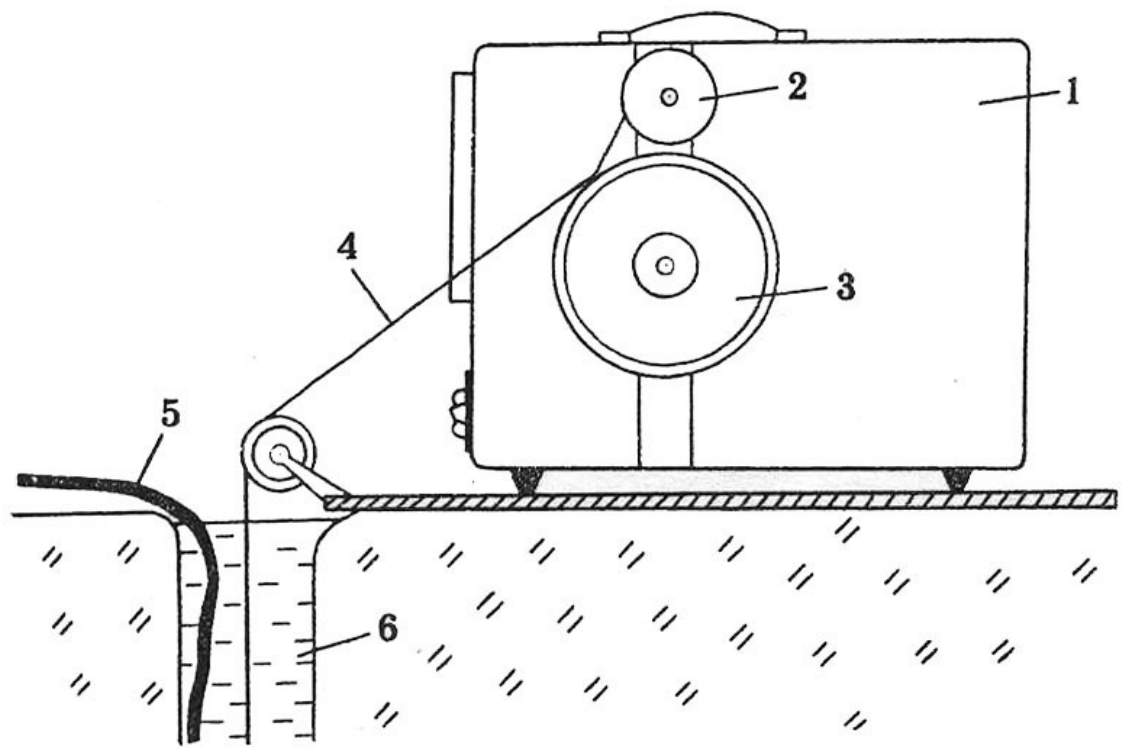

Figure 27. Device for recording penetration rate: (1) self-recorder; (2) cord spool; (3) tape transport sheave; (4) minimal stretch cord; (5) thermal drill cable; (6) borehole (from Zagorodnov et al. 1976).

\section{Vavilov Glacier (Severnaya Zemlya)}

The Vavilov Glacier, on October Revolution Island, is located between $79^{\circ}$ and $79^{\circ} 30^{\prime} \mathrm{N}$, and between $94^{\circ} 30^{\prime}$ and $97^{\circ} \mathrm{E}$ (Fig. 28). Its size is about $1817 \mathrm{~km}^{2} .287$ glaciers with a total area of $18,300 \mathrm{~km}^{2}$ are situated on the islands of the archipelago Severnaya Zemlya. 
In May of 1974, in the northern part of Vavilov Glacier, at an altitude of $665 \mathrm{~m}$ a.s.l. at $79^{\circ} 27^{\prime} \mathrm{N}$ and $95^{\circ} 21^{\prime} \mathrm{E}$, an all-winter Severozemel'skii Glaciological Station Kupol Vavilova was established (Govorukha 1981). It was closed down in 1989. During May-June 1974, two holes with depths of $80 \mathrm{~m}$ were drilled by an AARI drilling team using the hot point ETI-1 in the region of the glaciological station (Morev and Pukhov 1981). Then, to study drilling fluid stability, the first hole was filled with an aqueousethanol solution and the second one with diesel fuel. The temperature at a depth of $29 \mathrm{~m}$ was $-11.8^{\circ} \mathrm{C}$. At deeper levels, it increased with an average temperature gradient $0.02^{\circ} \mathrm{C} / \mathrm{m}$ (Barbash et al. 1981). After 1 year, both holes were opened and re-checked. The first hole was completely clean, and temperature measurements were identical to those made the year before. In the second hole filled by diesel fuel, a few slush plugs and a temperature divergence were found.

In July 1974, three more non-coring holes were drilled by a ETI-1 hot point to depths of 24, 20, and $20 \mathrm{~m}$ at different points of the Vavilov Glacier for measuring temperatures in an active layer of an ice cap.

\section{Abramov Glacier (Alai Ridge, Pamirs, drilling site \#CA3)*}

In the summer of 1974, a 105.8-m hole was drilled on Abramov Glacier using a thermal coring drill under the leadership of V.K. Nozdryukhin (Kislov 1976). The density measurements of 18 core samples from depths of 31.6 to $105.8 \mathrm{~m}$ gave values in the range of $908-909 \mathrm{~kg} / \mathrm{m}^{3}$.

\section{5-1977}

\section{Vavilov Glacier (Severnaya Zemlya)}

During March-May a group from the Leningrad Mining Institute (LMI) began research on Vavilov Glacier (Chistyakov et al. 1988). Since that time, drilling operations on Vavilov Glacier were conducted in parallel by two independent groups from the AARI and the LMI. The key target of the LMI research activity was testing and developing drilling and geophysical equipment for use in Antarctica. The building of a mobile drilling rig was started near the glaciological station Kupol Vavilova.

\footnotetext{
* see map Fig. 23 and Table 7.
} 
In May the drilling group of AARI drilled a hole to $60 \mathrm{~m}$ using a ETI-1 hot point also in the region of glaciological station Kupol Vavilova (Morev and Pukhov 1981).

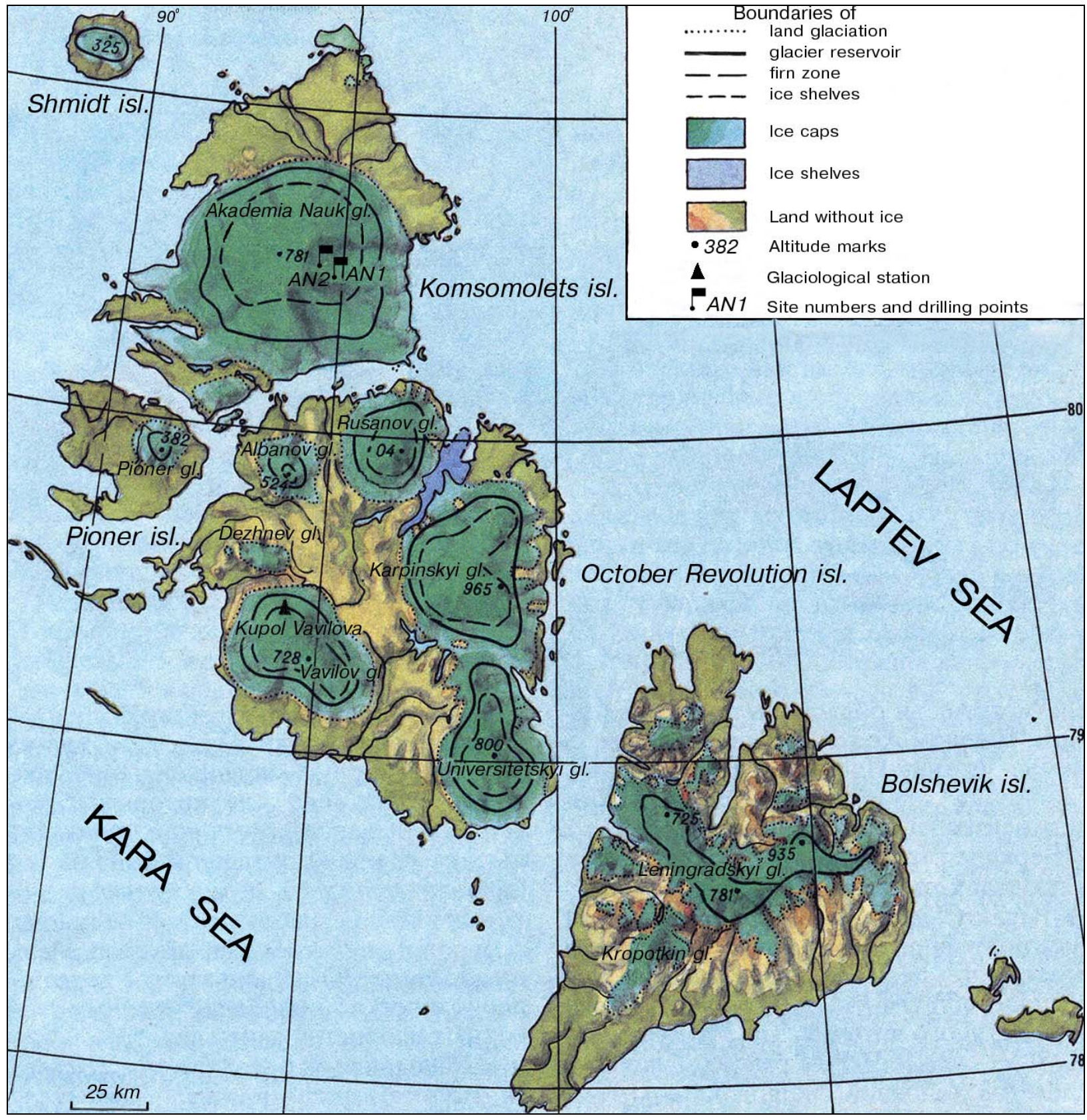

Figure 28. Severnaya Zemlya archipelago, showing location of glaciological station Kupol Vavilova and drilling sites.

During March-May 1975, the group from LMI built a mobile drilling rig on wooden sledges (Zagrivny et al. 1981; Chistyakov et al. 1988). The drilling rig was equipped with a tower $7.5 \mathrm{~m}$ high, a winch of the PK-2 type, an 
armored cable of the KEMPP- 6 type, and an electric drive motor generator with a power of $5 \mathrm{~kW}$.

During April-May 1976, the AARI tests of an anti-freeze thermal drill ETB-3 were completed and two holes were drilled to 17 and $15 \mathrm{~m}$ (Morev and Pukhov 1981). The first hole was drilled in the region of Kupol Vavilova, and the second one at the northern slope of the Vavilov ice cap.

From 6-18 May, a 310-m deep bore hole was drilled using a special antifreeze thermal electric hot point. Because of the accumulation of dirt at the hole bottom, which required excessive thrust loads, the axis of the hole deviated considerably from the vertical up to $45^{\circ}$ (sic). The true vertical depth of the hole was only $180 \mathrm{~m}$. Temperature measurements to a depth of $150 \mathrm{~m}$ were carried out by V.R. Barbash (Barbash et al. 1981). The temperature increased uniformly from $-13.8^{\circ} \mathrm{C}$ at the boundary of the active layer to $-12.5^{\circ} \mathrm{C}$ at $142 \mathrm{~m}$ as a positive temperature gradient was found in this interval.

In May a 459-m deep hole was drilled by an AARI team using an antifreeze thermal drill ETB-3 (Morev and Pukhov 1981). The hole was situated in the region of Kupol Vavilova and penetrated the glacier down to bedrock. The three-shift drilling operations took 15 days. Afterwards, hole temperature measurements and a deviation survey were made.

During May-October, the drilling group from the LMI tested a modified thermal coring drill TBZS-152M (Fig. 3b) (Zagrivny et al, 1981; Chistyakov et al. 1988). The thermal drill head was made from two tubular electric heaters molded into an annular copper body. The total power of the heaters was $2.5 \mathrm{~kW}$. To boost the reliability of the thermal drill head, each heater used an independent electric power supply. Three holes were drilled, all using one drill head.

The drilling of the first hole was started on 1 May 1977 but at $91.8 \mathrm{~m}$, drilling was terminated because of the necessity to change the cable on the winch (its length was only $110 \mathrm{~m}$ ) and also to move the drilling rig from the snowdrift-built pit. At this time the surface of the surrounding snow cover was $1 \mathrm{~m}$ above the roof of the drilling shelter. 
On 7 July 1977 the second hole was started, but at a depth of $51 \mathrm{~m}$ drilling was stopped again because heavy snow melting on the glacier surface caused melt water infiltration into the hole.

On 9 September 1977, the third hole was started. This hole reached bedrock at $462.2 \mathrm{~m}$. Drilling took 38 days, with an average rate of penetration of $2.03 \mathrm{~m} / \mathrm{h}$ and an average core length of $1.6 \mathrm{~m}$ per run. Owing to a shortage of drilling fluid (aviation fuel TS-1), drilling was done with a minimal amount of fluid in the hole (approximately $15 \mathrm{~m}$ above the bottom of the hole). In the interval from 429.9-431.8 m, ice containing an ample quantity of clay and sand was encountered.

\section{Ice-divide area between East Grënfjord and Fridtjof glaciers (Spitsbergen, drilling site \#S1)*}

In 1974 the second stage of Soviet glaciological research work in Spitsbergen (Fig. 29) was started and included more detailed studies of mass balance, hydrology, fluctuations of glaciers, composition, thermal regime, and evolution of glaciers in the archipelago during the Pleistocene and Holocene (Zagorodnov 1988). The drilling operations were started in June 1975 (Zagorodnov and Zotikov 1981a). Initially, to determine the depth of the firn, a few shallow holes were drilled with a ETI-1 hot point. The hot point was connected to a special recorder for registering the penetration speed. According to these measurements, the monolithic ice was found at $3.78 \mathrm{~m}$ from the surface. The next step in the research included core drilling using an ATED-ETB-3 (Fig. 8). The hole was drilled to $201.01 \mathrm{~m}$. The recovered core was of good quality and the diameter in the range of $78-80 \mathrm{~mm}$. The interval 201.01-211.11 $\mathrm{m}$ was penetrated by a ETI-1. (In papers of Zagorodnov et al. [1985] and Anonymous author [1986], the final depth was reported to be $213 \mathrm{~m}$. Koryakin [1981] wrote that the hole reached the glacier bedrock on 1 July at a depth of $212.6 \mathrm{~m}$.) The liquid level was maintained at a depth of $27 \mathrm{~m}$ within a few hours of each run by bailing or adding solution into the hole. Apparently, the glacier was pierced with channels and internal cavities containing water. Sometimes the cores contained channels with cross sectional areas of $10-200 \mathrm{~mm}^{2}$ and thin horizontal crevasses. The hole temperatures registered after a year, in June 1976, were as follows: $-0.27^{\circ} \mathrm{C}$ at $17 \mathrm{~m} ;-0.16^{\circ} \mathrm{C}$ at $32.4 \mathrm{~m}$; and $-0.38^{\circ} \mathrm{C}$ at $83 \mathrm{~m}$.

* see map Fig. 29 and Table 10. 
At the end of the 1975 field season, six no-core shallow holes were drilled on the smaller Věring Glacier (drilling site \#S2-see map Fig. 29 and Table 10) to the north of the first site (Zagorodnov in Kotlyakov 1985) during four working days.

\section{Kozel'skii Glacier (Kamchatka)}

Kozel'skii Glacier is situated on the south slope of the saddle between the Avachinskii and Kozel'skii volcanoes and has an area of $1.8 \mathrm{~km}^{2}$ (as of 1973). In May-June 1975, two holes with depths of 12 and $20 \mathrm{~m}$ were drilled using a conventional portable boring apparatus UKB-12/25 (total weight of the drill unit was nearly $110 \mathrm{~kg}$ ). The cuttings were recovered by an auger supplied with the boring apparatus. Instead of a conventional core barrel, a special shop-fabricated spoon bit had been used. Drilling in both holes was terminated when the boring head was stuck in a frozen scoria or ash layer (Vinogradov et al. 1981).

\section{Lomonosov Plateau (Spitsbergen, drilling site \#S3)*}

From 6 July to 6 August, drilling operations were carried out at an altitude of 1120 m a.s.l. using an ETB-3 anti-freeze thermal drill (Zagorodnov and Zotikov 1981a). The drilling was terminated at a depth of $201 \mathrm{~m}$ because of increasing slush formation at the bottom of the hole. The anti-freeze solution was bailed out to a depth of $178 \mathrm{~m}$ and the hole began to close at the rate of a few mm per day. The reason for the slush forming was the unusual temperature distribution in the hole. From the surface to $40 \mathrm{~m}$, the temperature increased from -2 to $-0.3^{\circ} \mathrm{C}$. In the interval $40-106 \mathrm{~m}$, a reverse temperature gradient was found, as the temperature decreased to $-2.6^{\circ} \mathrm{C}$ at $106 \mathrm{~m}$. This led to gravity circulation within the fluid. The lighter saturated ethanol solution moved up, and the heavier weak solution moved to the bottom and formed slush.

\footnotetext{
* see map Fig. 29 and Table 10.
} 


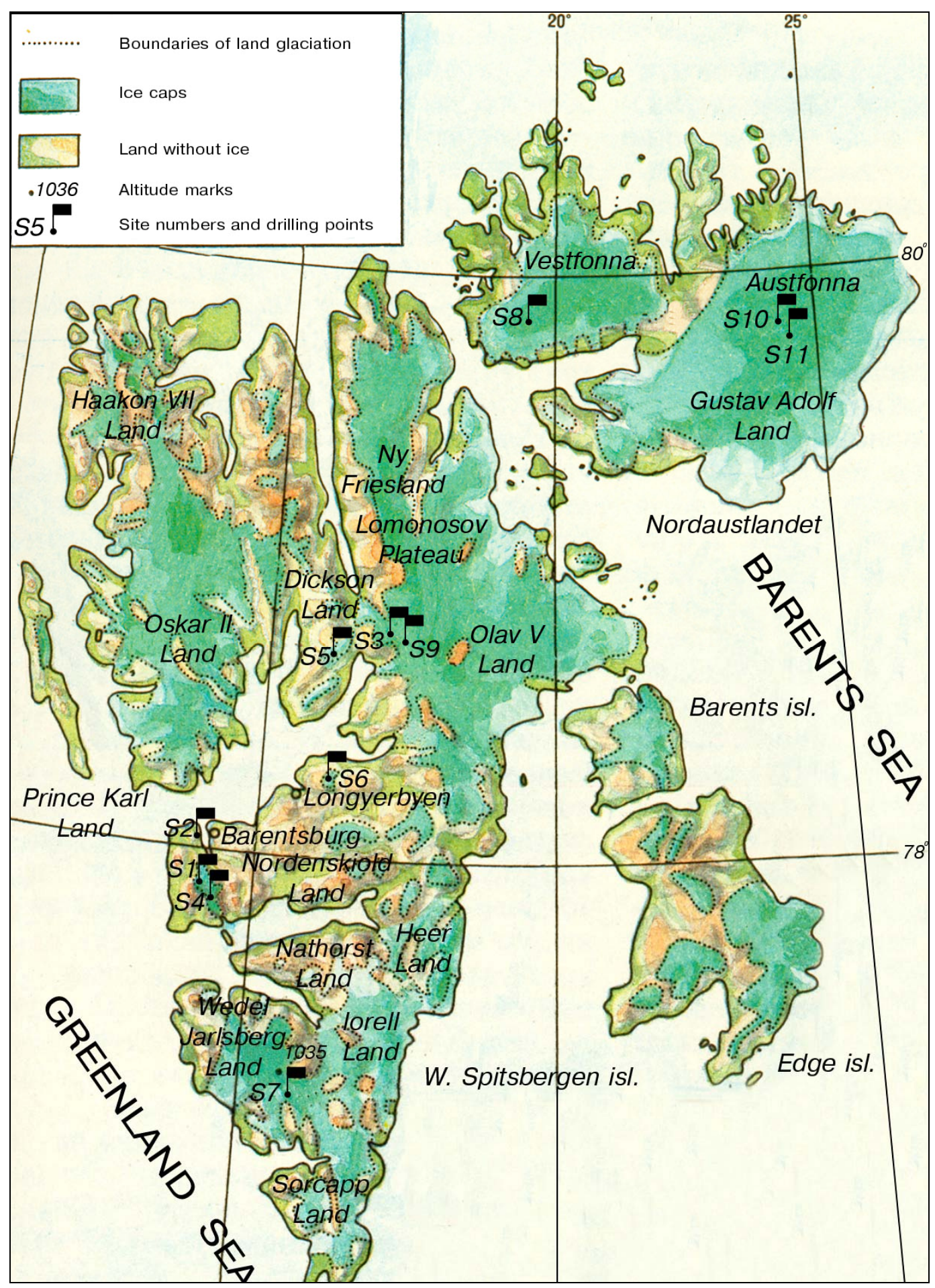

Figure 29. Spitsbergen archipelago and locations of drilling sites. 


\section{8-1979}

\section{Vavilov Glacier (Severnaya Zemlya)}

From 1 April 1978 until the 1 April 1979, the LMI team (A.M. Shkurko, E.A. Zagrivny, V.K. Chistyakov, Yu.A. Zelentsov, and M.S. Bugorkov) carried out ice drilling research on Vavilov Glacier at Kupol Vavilova (Zagrivnyi et al. 1979; Chistyakov et al. 1988). New lightweight thermal coring drills TBSK-93, TBS-93, TBS-93VCh were tested (Table 8).

Principally, the thermal drill TBSK-93 differed from the TBZS-152 not only in the outer diameter ( $93 \mathrm{~mm}$ ) but also in the fluid circulation system. The melt water was picked up by the drilling fluid flow and passed through holes in the upper part of the drill head and then along the clearance between the inner surface of the core barrel and the core. Then, the drilling fluid and water entered the central tube of the water tank where the water was collected by gravity separation. The core barrel was made from thickwalled tubing with an OD/ID of $89 / 77 \mathrm{~mm}$. To prevent icing on the surface of the core barrel, a special electrical heating element was installed in a spiral slot machined on the outer surface of the core barrel.

The construction of the TBS-93 drill differs from the TBSK-93 drill in the design of the core barrel and water tank. The water tank was made from thin-walled tubing that is closed on the lower end. The tank is inserted into the core barrel and is free to move. During drilling, the tank is lifted by the core. The outer diameter of the water tank is approximately the same as the core diameter. The melt water was picked up by the drilling fluid flow and passed along the clearance between the inner surface of the core barrel and the core/water tank. In the space above the water tank, the flow rate rapidly decreases and water drops are swept down owing to the density difference from the drilling fluid.

The TBS-93VCh thermal drill was a prototype of the TBS-112VCh drill (Fig. 3c), which was used later during SAE 26-30 at Vostok station. The only difference was the outer diameters of the drill head, core barrel, water tank, etc.

The new thermal drills were tested in April-May and in October of 1978 (Table 9). Initially, a TBZS-152M thermal drill was used to reach $27.5 \mathrm{~m}$. The TBS-93 thermal drill was then used to deepen the bore hole in the interval of $27.5-45.3 \mathrm{~m}$ with the following average characteristics: core 
length $0.63 \mathrm{~m}$, rate of penetration $4.73 \mathrm{~m} / \mathrm{h}$, and drill head power $3.2 \mathrm{~kW}$. The drilling fluid was TS- 1 aviation fuel. The recovered core had a cylindrical form in the lower part and a conic frustum in the upper part. The drilling of this hole was then continued by a thermal drill of the TBS-93VCh type, with the following average characteristics: core length $0.66 \mathrm{~m}$, rate of penetration $7.34 \mathrm{~m} / \mathrm{h}$, and drill head power $4-5 \mathrm{~kW}$. At $49.3 \mathrm{~m}$, to study the possibility of retrieval after an accident, the thermal drill was intentionally frozen in with $2.5 \mathrm{~m}$ of melt water. After 29 hours the power to the heating head was turned on and in 3.3 hours the drill was released.

In October of 1978 the TBSK-93 thermal drill was tested. A 90-m-deep hole was drilled from the surface. A considerable quantity of melt water remained in the hole bottom. This unsatisfactory condition required redrilling already penetrated intervals. The total length of the drilling was $130 \mathrm{~m}$. The average drilling characteristics were: core length $1.71 \mathrm{~m}$, rate of penetration $3.0 \mathrm{~m} / \mathrm{h}$, and drill head power $1.3-1.5 \mathrm{~kW}$. A calcium bromide $\left(\mathrm{CaBr}_{2}\right)$ salt solution with a density near $1020 \mathrm{~kg} / \mathrm{m}^{3}$ was tested as a drilling fluid and $70 \mathrm{~m}$ of the hole was drilled with this solution in the bottom of the hole. The tests proved the possibility of using a salt solution as a drilling fluid in thermal drilling. There was no refreezing of the melt water or the formation of slush. The concentrated salt solution was gradually diluted by the melt water and it was necessary to keep the density of the solution at the bottom at not less than $1003 \mathrm{~kg} / \mathrm{m}^{3}$.

One of the ice coring development tasks was testing a TBZS-152M modified drill, with new molded aluminum and copper thermal drill heads. A 460-m-deep hole to bedrock was drilled from 13-30 November 1978 and continued from 17 December 1978 to 10 January 1979. The interruption was caused by a drilling fluid (aviation fuel TS-1) shortage and the subsequent wait for its delivery. The average drilling characteristics were as follows: core length $1.76 \mathrm{~m}$, rate of penetration $1.9 \mathrm{~m} / \mathrm{h}$, and drill head power $2.5 \mathrm{~kW}$. The inclinometer survey showed a significant inclination of the hole (Barkov et al. 1988). Down to $90 \mathrm{~m}$, the hole inclination rapidly increased to $6.6^{\circ}$ and then increased gradually to $12^{\circ}$ near the bottom. The hole temperature increased from $-11.62^{\circ} \mathrm{C}$ at $20 \mathrm{~m}$ to $-6.1^{\circ} \mathrm{C}$ near the glacier bed. The temperature gradient decayed with depth from $0.015^{\circ} \mathrm{C} / \mathrm{m}$ near the surface to $0.007^{\circ} \mathrm{C} / \mathrm{m}$ near the bed of the glacier.

In April-May 1979, LMI drilled nearly a dozen shallow holes in the region of Kupol Vavilova station using thermal drills TBZS-152M and a light- 
weight MTBS-66 (see Table 9). The main purpose was the testing of new compositions of drilling fluid. Saturated hydrocarbons of the alkyl type with a density of $1200 \mathrm{~kg} / \mathrm{m}^{3}$ as well as a mixture of TS- 1 aviation fuel with trichloroethylene (density of $900-1100 \mathrm{~kg} / \mathrm{m}^{3}$ ) and with anti-freeze (density $900-1000 \mathrm{~kg} / \mathrm{m}^{3}$ ) were tested.

During April-May 1979, a 556.5-m deep hole was drilled to bedrock in the central part of Vavilov Glacier, $11 \mathrm{~km}$ southeast of Kupol Vavilova by an AARI drilling team (Morev and Pukhov 1981; Morev et al. 1981; Morev et al. 1988). The radar sounding at this point measured the glacier thickness to be $551 \mathrm{~m}$. The anti-freeze technology with an ETB-3 thermal drill was used for drilling in the intervals $0-4.5$ and $105-556.6 \mathrm{~m}$. The interval 4.5$105 \mathrm{~m}$ was drilled with an "ETB-5" thermal drill (Fig. 9). The average rate of penetration was in the range of 3.5-4.0 $\mathrm{m} / \mathrm{h}$ at a drill head power near $3.2 \mathrm{~kW}$. The core diameter was $75^{-78} \mathrm{~mm}$; and the core length per run was approximately $2 \mathrm{~m}$. The brittle zone was found to be in the interval from 150 to $375 \mathrm{~m}$. During the drilling process a 3-5 $\mathrm{m}$ thick slush layer appeared at the upper part of the fluid column and led to difficulties, particularly in the lowering and raising of the drill in the hole. To decrease the formation of slush, the weak ethanol solution in the upper part of the fluid column was partially changed to a stronger ethanol solution at the end of each shift. After the termination of drilling the deviation survey showed that the hole inclination was in the range of $3 \cdot 5^{\circ}$.

In November 1979, tests of the modified TBZS-152M thermal coring drill and the TBSK-93 thermal coring drill were continued on Kupol Vavilova station by LMI drillers (Chistyakov et al. 1988). First, a 52.4-m-deep hole was drilled with the TBZS-152M. Then the TBSK-93 drill was used to reach $95.5 \mathrm{~m}$. The following characteristics (the first number refers to the TBZS$152 \mathrm{M}$ drill and the second number to the TBSK-93 drill) were observed: penetration rate 1.0 and $2.15 \mathrm{~m} / \mathrm{h}$; core length 1.1 and $1.1 \mathrm{~m}$; and drill head power 2.2 and $1.0 \mathrm{~kW}$.

\section{Fridtjof glacier (Spitsbergen, drilling site \#S4 )*}

The drilling site was situated $2 \mathrm{~km}$ from the ice-divide area at an altitude of $380 \mathrm{~m}$ a.s.l. (Zagorodnov et al. 1985). According to radio echo sound-

* see map Fig. 29 and Table 10. 
ings, the ice thickness was estimated to be $220 \pm 10 \mathrm{~m}$. Three holes were drilled with an ETB-3 anti-freeze thermal drill to depths of 48, 114, and $119 \mathrm{~m}$ (Kotlyakov 1985). The third hole was continued by a non-coring ETI-1 from $119 \mathrm{~m}$ to $220 \mathrm{~m}$. Owing to a significant hole inclination and a limited cable length, bedrock was not reached. After the termination of drilling, a deviation survey was carried out (Macheret et al. 1984). The maximum inclination was $9-10^{\circ}$ measured at a depth of $150 \mathrm{~m}$.

\section{0}

\section{Vavilov Glacier (Severnaya Zemlya)}

In March of 1980 testing of calcium bromide as a drilling fluid was continued and an 80-m-deep hole was drilled by LMI in the region of Kupol Vavilova station using a TBZS-152M thermal drill (Chistyakov et al. 1988).

During the spring-summer season of 1980, the drilling group from the AARI (leader V.M. Yakovlev) tested the ETB-3 anti-freeze thermal drill in the central part of the Vavilov Glacier, $11 \mathrm{~km}$ to the southeast of Kupol Vavilova (Morev et al. 1988). Four holes were drilled to depths of 10-25 $\mathrm{m}$. Then, a new light-weight version of the ETB-3 thermal drill, with a core barrel 0.7-m long and new cased drill heads, was tested as well. The cased drill head provided the inflow of the ethanol solution closer to the bottom so that only the lower $10-12 \mathrm{~mm}$ (instead of $70-80 \mathrm{~mm}$ in the previous design) of the drill head was immersed in melt water.

In May 1980, a bore hole to a depth of $57 \mathrm{~m}$ was drilled in the northwest part of the Vavilov Glacier using the ETI-1 thermal electric point. The drill was raised and lowered via a manual cable winch. At the bottom the hole inclination was close to $4^{\circ}$.

\section{Bertil Glacier (drilling site \#S5), Bogger Glacier (drilling site \#S6), and Amundsen Plateau (drilling site \#S7), Spitsbergen*}

In the summer of 1980, specialists from IGAS (V.S. Zagorodnov, A.S. Gus'kov, V.M. Gokhman, O.Yu. Samoilov, A.S. Medvedev and M.N. Pukemo) continued ice drilling on Spitsbergen glaciers (Zagorodnov 1981; Zagorodnov and Samoilov 1982a; Samoilov and Zagorodnov 1985). Three holes were drilled on Bertil Glacier (central part of Western Spitsbergen

* see map Fig. 29 and Table 10. 
Island) using a ETI-1 hot point. The first hole reached bedrock at a depth of $108 \mathrm{~m}$ (true vertical depth $107.5 \mathrm{~m}$ ). The drilling of the second hole was terminated at $53 \mathrm{~m}$ where an englacial debris-containing layer was encountered. After the termination of drilling, the liquid level in these holes were monitored for 1 month. The liquid level was rather stable in spite of periodic bailing of the drilling fluid. As a result of these measurements, it was concluded that there was no inflow of water and that the Bertil Glacier doesn't contain a liquid phase. The temperature in the first hole increased from $-9^{\circ} \mathrm{C}$ near the surface to $-1.1^{\circ} \mathrm{C}$ at the bottom. The temperature distribution in the second hole was quite different, as the temperature rapidly increased from $-12^{\circ} \mathrm{C}$ near the surface to $-0.5^{\circ} \mathrm{C}$ at $50 \mathrm{~m}$. One hole was drilled with a thermal coring drill primarily to obtain core (Kotlyakov 1985) and was terminated at $7 \mathrm{~m}$.

Bogger Glacier is situated about $150 \mathrm{~km}$ south of Bertil Glacier and is approximately the same size. In the central part, at an altitude of $600 \mathrm{~m}$ a.s.l., three holes were drilled using the ETI-1 thermal electric point. It was possible to penetrate only the first few meters because water drained into the hole from the surface and froze on the bore hole wall. One hot point was lost at a depth of approximately $4 \mathrm{~m}$ (Zagorodnov, personal communication, 2005).

During May-June 1980, a deep hole was drilled in the central part of the Amundsen Plateau (southern part of Western Spitsbergen Island). The upper $386.5 \mathrm{~m}$ was drilled with an ETB-3 anti-freeze thermal drill (Zagorodnov 1988). At $150 \mathrm{~m}$ a brittle zone was encountered and the recovered core was cracked in pieces of $3-15 \mathrm{~cm}$ in size. Drilling was continued to bedrock at $586 \mathrm{~m}$ with the ETI-1 hot point. Approximately $20 \mathrm{~m}$ above the bottom, the hot point was accidentally disconnected from the cable. A new drill and a whip stock were built from available material and a spare heating head. The whip stock was installed just above the lost drill which was successfully bypassed. After the end of drilling, a deviation survey was carried out. The inclination in the main part of the hole didn't exceed $1-2^{\circ}$ and near the bottom abruptly increased to $30^{\circ}$. Taking into account the hole inclination, the true vertical depth was near $580 \mathrm{~m}$. Monitoring of the liquid level after termination showed that the englacial water regime of the Amundsen Plateau differed from that of the Bertil Glacier (Zagorodnov and Zotikov 1981b). The liquid level in the hole rapidly returned after bailing. For example, at a depth of $100 \mathrm{~m}$, the liquid level rose at a rate of $2 \mathrm{~m} / \mathrm{h}$. 


\section{1}

Vestfonna (Nordaustlandet, Spitsbergen, drilling site \#S8)*

A drilling camp was organized on the 18 June 1981 in the southwest part of the Vestfonna ice cap at $79^{\circ} 56^{\prime} \mathrm{N}$ and $19^{\circ} 31^{\prime} \mathrm{E}$ at an altitude of $580 \mathrm{~m}$ a.s.l. (Zagorodnov and Zinger 1982; Punning et al. 1985). The team consisted of eight specialists from the IGAS, Institute of Geology of Estonian SSR, and Moscow State University. From 25 June to 4 July, five holes were drilled by an ETB-3 anti-freeze thermal core drill. The deepest hole reached bedrock at $208.2 \mathrm{~m}$. The mean rate of penetration was $3.3 \mathrm{~m} / \mathrm{h}$ and the core production was $40-45 \mathrm{~m}$ per $12-14$ hours of drilling. The maximum inclination of the holes was $7^{\circ}$. Afterwards, three boreholes (24, 20, and $72 \mathrm{~m}$ ) were drilled with a ETI-1 hot point at a mean penetration rate of 10-18 $\mathrm{m} / \mathrm{h}$. To reach $72 \mathrm{~m}$ in below freezing weather, melt water was periodically bailed from the hole (Zagorodnov in Kotlyakov 1985).

\section{Vavilov Glacier (Severnaya Zemlya)}

During September-October 1981, a device for carbon analysis sampling was tested on Kupol Vavilova station by an LMI research group (Zemtsov and Men'shikov 1988; Chistyakov et al. 1988). This device was designed for melting a large cavity at the bottom of a dry hole and the simultaneous sampling for carbon dioxide from the air bubbles trapped in the ice. Tests were conducted in a 52-m hole drilled by a modified TELGA-14M thermal coring drill with a drill head OD of $152 \mathrm{~mm}$ (Fig. 3a) (the above mentioned authors referred to this thermal drill as TELGA-152).

In December of 1981 near the Kupol Vavilova station a 410-m-deep hole was drilled by a TBZS-152M thermal coring drill with the following characteristics: penetration rate $2.7 \mathrm{~m} / \mathrm{h}$; core length $1.98 \mathrm{~m}$; and drill head power $3.4 \mathrm{~kW}$. The TS-1 aviation fuel was used as a hole fluid. After the end of drilling, the upper permeable zone was cased with steel tubing with an OD of $127 \mathrm{~mm}$ (Chistyakov et al. 1988).

* see map Fig. 29 and Table 10. 


\section{Vavilov Glacier (Severnaya Zemlya)}

Two holes were drilled to bedrock by an AARI drilling team (leader A.I. Tolstoi) using an ETB-3 anti-freeze thermal drill (Morev et al. 1988). The first hole was drilled at a site $20 \mathrm{~km}$ southwest of Kupol Vavilova to a depth of $468.5 \mathrm{~m}$. One and a half months after the end of drilling, a temperature survey was carried out in the hole. The temperature distribution was very unusual. In the upper part of the hole, the temperature gradually increased from $-9.9^{\circ} \mathrm{C}$ at $10 \mathrm{~m}$ to $-8.3^{\circ} \mathrm{C}$ at $70 \mathrm{~m}$. From here, the temperature decreased to $-9.5^{\circ} \mathrm{C}$ at $200 \mathrm{~m}$ and then increased again to $-8.65^{\circ} \mathrm{C}$ at the bottom of the hole.

The second drilling site was located $8 \mathrm{~km}$ northwest of the glaciological station close to the termination of the glacier. Here, the hole was drilled to a depth of $146 \mathrm{~m}$. The hole inclination did not exceed $1.5^{\circ}$.

\section{Lomonosov Plateau (Spitsbergen, drilling site \#S9)*}

In July, 1982 members of the IGAS continued the deep ice structural and textural investigations of the Lomonosov Plateau using thermal drilling equipment that had been used in previous expeditions on Spitsbergen (Zagorodnov et al. 1984). The drilling site was located at an altitude of $1040 \mathrm{~m}$ a.s.l. at $78^{\circ} 44^{\prime} \mathrm{N}$ and $17^{\circ} 34^{\prime} \mathrm{E}$, approximately $10 \mathrm{~km}$ to the south of the 1976 drilling site. Three holes were drilled: one to $35 \mathrm{~m}$ by an ETI-1 hot point and two holes to 31 and $135 \mathrm{~m}$ by an ETB-3 anti-freeze thermal drill. The last hole reached bedrock. The previous drilling operations at Lomonosovfonna with an ethanol-water solution revealed that slush rapidly formed in the upper part of the holes drilled in glaciers with an inverse temperature gradient. That is why at the end of each drilling shift the drilling liquid was bailed out of the hole. This method was used down of 100 $\mathrm{m}$, below which the hole was filled with anti-freeze.

\footnotetext{
* see map Fig. 29 and Table 10.
} 


\section{Vavilov Glacier (Severnaya Zemlya)}

In April of 1983 the temperature survey of the 468.5-m-deep hole drilled $20 \mathrm{~km}$ to the southwest of Kupol Vavilova a year before was repeated (Morev et al. 1988). The temperature distribution was generally the same but lower by approximately $1^{\circ} \mathrm{C}$. Then a new hole to a depth of $467 \mathrm{~m}$ was drilled at the site. The ETB-3 anti-freeze thermal drill was used (leader of the drilling team was Yu.V. Raikoskyi from the IGAS). New higher performance thermal drill heads were tested. To decrease the slush forming in the hole, a densifier (glycerin) in a quantity of $2 \%$ of fluid volume was added to the drilling fluid.

During April-June of 1983, two dry holes were drilled to 200 and $100 \mathrm{~m}$ by members of the LMI using a TELGA-14M thermal drill to sample the carbon dioxide from the air bubbles trapped in the ice (Zemtsov and Men'shikov 1988; Chistyakov et al. 1988). In the course of drilling, the following average characteristics were obtained: penetration rate $2.7 \mathrm{~m} / \mathrm{h}$, core length $2.1 \mathrm{~m}$, and power $3.4 \mathrm{~kW}$.

\section{Dzhantuganskoye Firn Plateau (Central Caucasus, drilling site \#C5) ${ }^{*}$}

Beginning in 1982, members of the LMI, generally students of the Department of Drilling Technique and Technology, designed special lightweight equipment for drilling in remote and high mountain glaciers (Vasiliev et al. 1993). All surface equipment was mounted on aluminum sledges except the gasoline electric power generator (Fig. 30). The winch with $100 \mathrm{~m}$ of KG1-40-180 cable was driven by a $0.6-\mathrm{kW}$ electric motor. The total weight of the drilling equipment was near $130 \mathrm{~kg}$. The MTBS-76 thermal drill was configured without a pump and water tank. After each run, the drill was disconnected from the cable. Then a bailer with a bottom valve was connected to a cable and lowered into the hole for picking up the melt water. The drilling system was used by the Glacier Party of the Basic Research Laboratory of Snow Slides and Debris Flows (Moscow State University) and the North-Caucasus Geographic Expedition of IGAS on the glaciers of the Caucasus, Tien-Shan, and Kodar Range. A total of nine holes were drilled on mountain glaciers with a total cumulative depth of

\footnotetext{
* see map Fig. 21 and Table 7.
} 
$419 \mathrm{~m}$. The deepest hole of $93 \mathrm{~m}$ was drilled on Dzhantuganskoye Firn Plateau on the northern slope of the Main Caucasus Ridge in August of 1983 (Golubev et al. 1988; Vasiliev et al. 1993). The length of the Plateau is nearly $3 \mathrm{~km}$, its width is $1-1.5 \mathrm{~km}$, and the average altitude is $3650 \mathrm{~m}$ a.s.l. The average thickness is $160-180 \mathrm{~m}$ according to radio-echo sounding data. A 93-m-deep hole was drilled by two men over 127 hours (the total penetration time of drilling was 68 hours). The average length of run was about $2 \mathrm{~m}$, the rate of penetration was $1.5 \mathrm{~m} / \mathrm{h}$ at a drill head power of about $1 \mathrm{~kW}$.

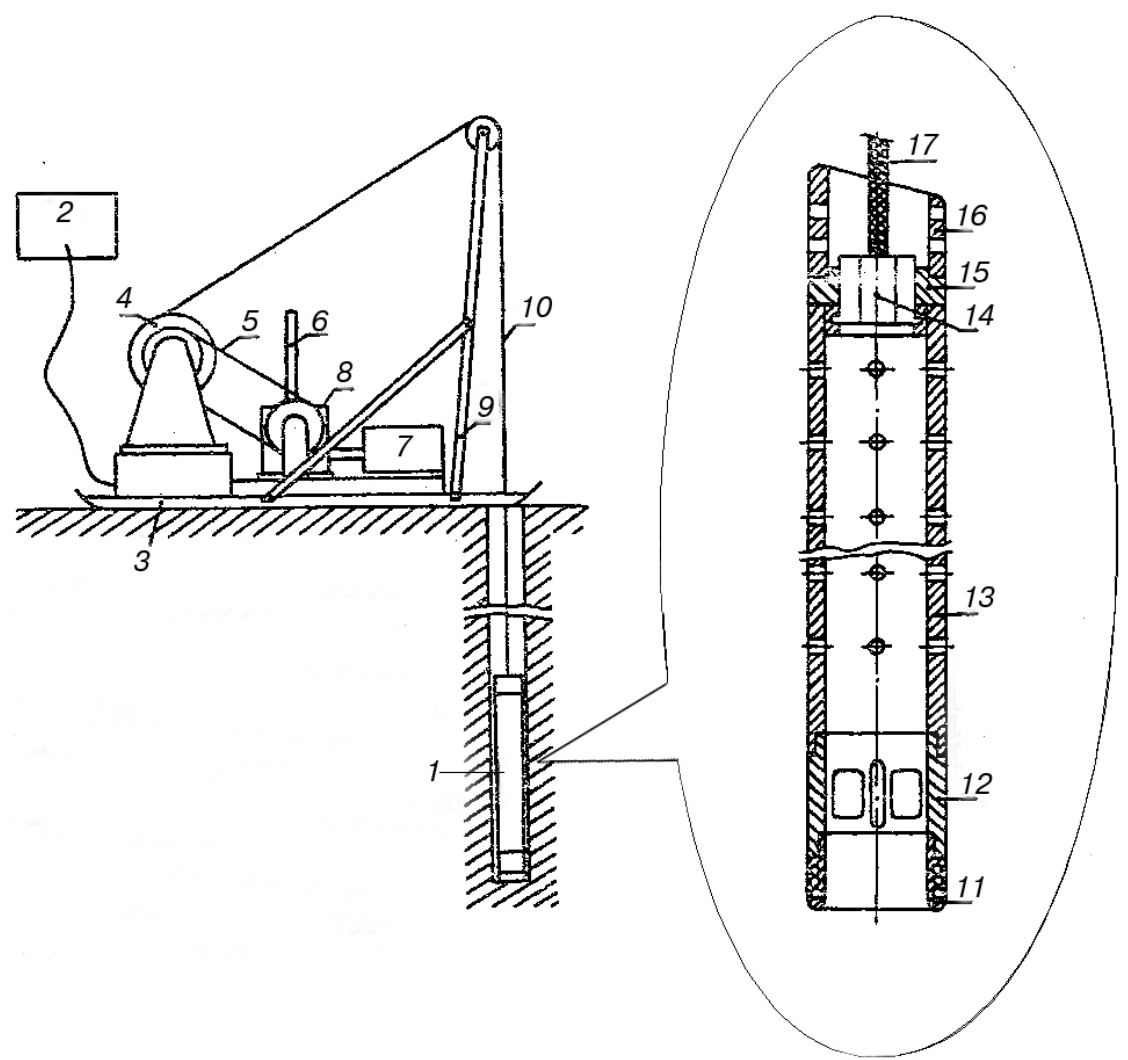

Figure 30. Lightweight thermal drilling rig of LMl: (1) thermal drill of MTBS type; (2) gasoline electric power station; (3) aluminum sledge; (4) winch; (5) driving-belt; (6) clutch; (7) motor reducer; (8) worm reduction gearbox; (9) mast with wheel; (10) cable; (11) thermal drill head; (12) core cutter; (13) core barrel; (14) detachable cable termination; (15) coupling; (16) upper chip catcher; (17) lower part of cable (from Vasiliev et al., 1993)

\section{4: Vavilov Glacier (Severnaya Zemlya)}

In the spring of 1984, under the leadership of L.N. Manevskyi (AARI), the ETB-130 thermal drill was tested $11 \mathrm{~km}$ to the southwest of glaciological station Kupol Vavilova (Morev et al. 1988). The drill was designed for dry 
hole core drilling. A 110-m-deep hole was drilled. The diameter of the recovered core was 79-80 $\mathrm{mm}$ and the hole diameter was near $135 \mathrm{~mm}$.

In May 1984, the temperature survey of the 468.5-m-deep hole (drilled in 1982, $20 \mathrm{~km}$ to the southwest of Kupol Vavilova) was repeated. The deviations of temperature from the earlier measurements were within 0.1$0.2^{\circ} \mathrm{C}$. The temperature measurements in the $467-\mathrm{m}$-deep hole (drilled in 1983) were carried out as well. The slush plugs in either hole were not encountered.

In June of 1984 the inclination of the borehole drilled to $146 \mathrm{~m}$ near the edge of the glacier in 1982 was measured. Initially, the hole was almost vertical. The inclination increased slightly from the surface to $1.9^{\circ}$ at a depth of $80 \mathrm{~m}$ and rapidly increased to $18^{\circ}$ at the bottom.

The first tests of the KEMS-112, (Fig. 31) an electro-mechanical drill designed by the LMI was begun in the winter-spring campaign of 1984 (Chistyakov et al. 1988; Bobin et al. 1988; Kudryashov et al. 1994; Vasil'yev et al. 1993). Cutting head OD/ID dimensions were 112-116/87 mm. The length of the core barrel was $1.5 \mathrm{~m}$ and the length of the chip chamber was $1.8 \mathrm{~m}$. TS-1 aviation fuel was used as the drilling fluid. From 15 to 24 May, the hole was drilled to $89 \mathrm{~m}$. A modified TELGA-14M thermal drill was used to drill through the upper 30-m of permeable and crumbling ice. The average drilling characteristics in the interval of 43.6-89 m were: chip density in the filter $300-390 \mathrm{~kg} / \mathrm{m}^{3}$; average length of run $0.63 \mathrm{~m}$; average rate of penetration $23.6 \mathrm{~m} / \mathrm{h}$; and an average core production rate 6.5 $\mathrm{m} /$ day. As a result of the first electro-mechanical drilling experience, it was concluded that the use of special operational and surface handling equipment would be needed. During the next year a device for providing a uniform drill feed and improved drill assembling and disassembling devices were designed and manufactured. 


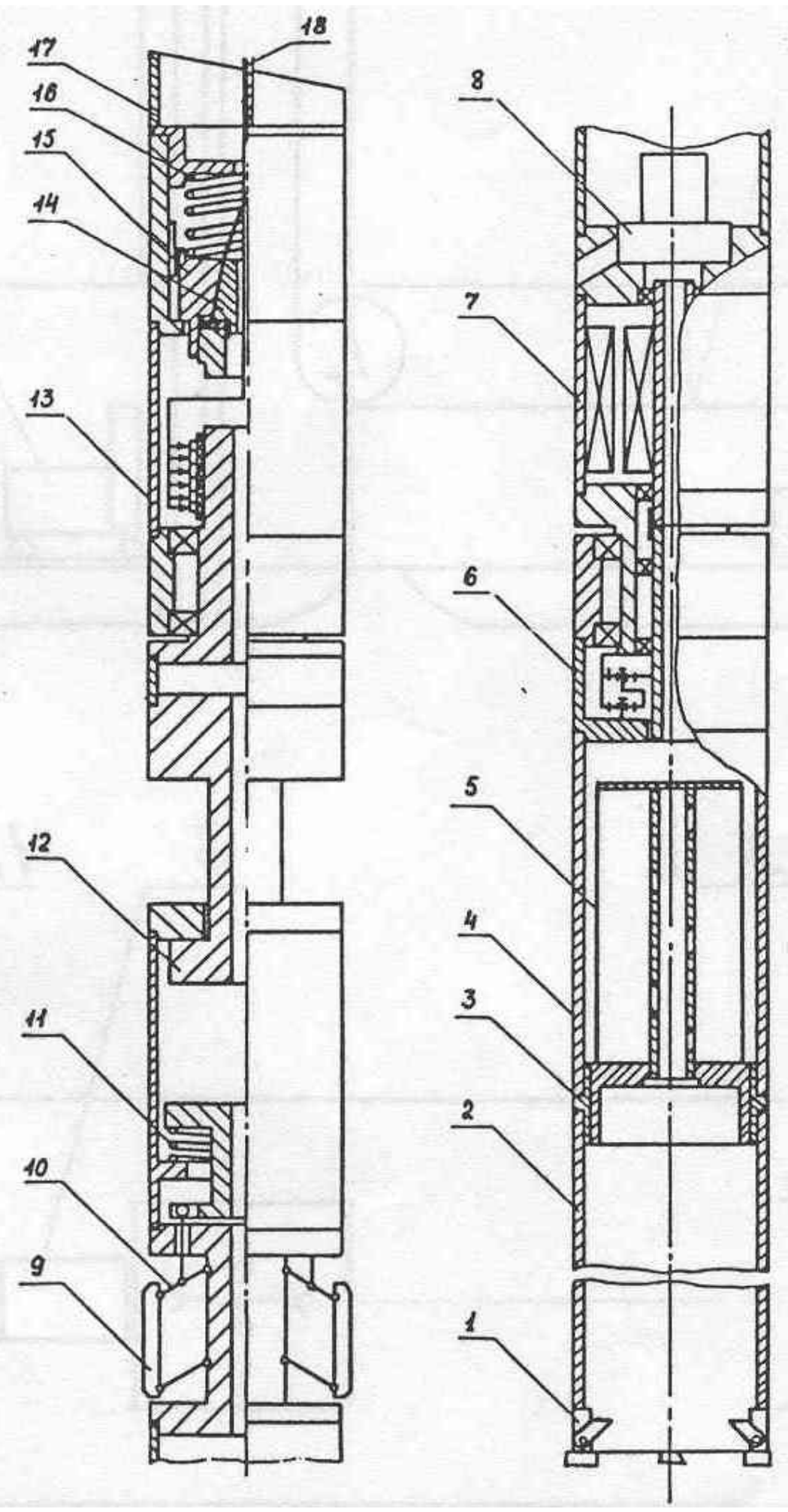

Figure 31. KEMS-112 electro-mechanical core drill: (1) drill head, (2) core barrel, (3) nipple, (4) barrel, (5) chip filter, (6) gear reducer, (7) electric drive motor, (8) pump, (9) skates, (10) lever system, (11) spring, (12) hammer block, (13) electric chamber, (14) copper cone, (15) plug, (16) spring, (17) chip collector, (18) cable. 


\section{5}

\section{Vavilov Glacier (Severnaya Zemlya)}

In February-March of 1985 at Kupol Vavilova station, a new PTBS-112 steam thermal drill (Table 8), designed for drilling dry holes in ice, was tested at the LMI (Chistyakov et al. 1988). The steam was generated in a hot-water boiler installed inside the drill, from which it discharged to the coring head. After melting of the annular groove at the hole bottom, the water-steam mixture is directed to a water tank where the residual steam is condensed. This drill can achieve a rate of penetration 4-5 times higher than ordinary thermal drills and with lower power consumption. During tests of the PTBS-112 thermal drill, a 50-m-deep hole was drilled.

In the spring of 1985, tests of a thermal drill of the ETB-130 type designed for drilling dry holes were continued $26 \mathrm{~km}$ southwest of Kupol Vavilova (Morev et al. 1988). A 102-m-deep hole was drilled.

In May 1985, temperature surveys in the 468.5-m hole (drilled in 1982) and the 467-m hole (drilled in 1983) were carried out. The temperature probe was lowered into the boreholes without any complications. But on the way back up slush plugs at the top of the fluid column were encountered and it was impossible to recover the probe. To set it free, the plugs were penetrated with thermo-electric points lowered from the surface. The thickness of the slush plug in the first hole was estimated to be $1.5 \mathrm{~m}$ and in the second hole $1 \mathrm{~m}$. It appears that immersing the cold thermal probe and cable into the equilibrium ethanol-water solution caused the formation of an icy slush. The slush then moved up to the top of the fluid column and formed a plug.

\section{Austfonna (Nordaustlandet, Spitsbergen, drilling site \#S10)*}

On 23 May, the first group from IGAS arrived in the region of maximum ice thickness (550-570 $\mathrm{m}$ according to radio-echo soundings carried out in 1984) of the Austfonna ice field (Anonymous author 1986; Arkhipov et al. 1987; Zagrodnov and Arkhipov 1990c). Because of heavy fog, the helicopter put down $4 \mathrm{~km}$ from the intended landing point. By 10 June, all members of the glaciological team and equipment were brought to the originally planned site. The drilling shelter was built at the main site and

* see map Fig. 29 and Table 10 
equipped with two power generators of the AB-4-T-230 type (Fig. 32). The field season operated up to the 2nd of August.

The drilling operations included hand auguring and anti-freeze thermal drilling. The IGAS-built hand auger included an aluminum core barrel, extension rods, a T-handle driver, and a device at the mouth of the hole to grasp the string when connecting or disconnecting the extension rods. The total weight of equipment for a $32-\mathrm{m}$ set was $38-40 \mathrm{~kg}$. The drill produced up to $0.5-\mathrm{m}$ cores with a diameter of 90-92 $\mathrm{mm}$ and length (length of run) of $0.2-0.5 \mathrm{~m}$. This equipment drilled 10 holes with depths from 6.3 to 15.8 $\mathrm{m}$.

On 6 July the first anti-freeze hole was drilled to a depth of $32.4 \mathrm{~m}$ with the anti-freeze ETB-3 thermal drill. The drilling was terminated because of severe englacial water problems. However, from 9 to 14 July a 204.1-mdeep hole was made by the same ETB-3 drill. The drilling was ended again because the englacial water flowed into the hole and froze on the hole wall. The water inflow also caused slush to form in the upper part of the fluid column. The water continued to flow in spite of casing the hole to a depth of $7 \mathrm{~m}$. Two other anti-freeze holes were drilled to $53.7 \mathrm{~m}$ (18 July) and $60.9 \mathrm{~m}$ (25-26 July). Drilling of both of these holes was stopped for the same reason-water inflow. The distances between the mouths of all of the holes were $0.5-2 \mathrm{~m}$. Anti-freeze drilling was proceeding with an ethanol concentration in the range of $10-20 \%$. The drilling shelter and other structures were left at this site for future operations.

\section{Davydov Glacier (Akshirak, Internal Tien Shan, drilling site \#CA4 )*}

Akshirak is a high mountain massif in the western part of the Internal Tien Shan (East Kyrgyzstan). Almost half of Akshirak territory is covered by glaciers-154 glaciers with a total area of $435.8 \mathrm{~km}^{2}$ are situated here. Davydov Glacier is situated on the northern slope of Akshirak (Aizen and Zakharov 1989). Its length is $5.8 \mathrm{~km}$ and its area is $11.6 \mathrm{~km}^{2}$. The edge of the glacier is situated at an altitude of $3780 \mathrm{~m}$ a.s.l. From the 15 to 21 July, in the middle part of Davydov Glacier, a 109-m-deep bore hole was drilled by a TBI-70-P thermal point (Table 8) designed by the LMI (Vasilenko et al. 1988). In the interval of $0-15 \mathrm{~m}$, several narrow sections caused by refrozen water on the hole wall were encountered by the thermal point during hoisting. As a result, drilling runs (to the depth of $40 \mathrm{~m}$ ) were alter-

* see map Fig. 23 and Table7. 
nated with water bailing. The rate of penetration down to $102 \mathrm{~m}$ was a rather stable $3 \mathrm{~m} / \mathrm{h}$. From there, the rate rapidly decreased, apparently because of solid inclusions in the ice and, at $109 \mathrm{~m}$, the penetration stopped. The inclinometer survey showed that the hole was almost vertical and the inclination didn't exceed $2^{\circ}$. The temperature was measured only down to $30 \mathrm{~m}$. The hole temperature at first decreased from $-0.2^{\circ} \mathrm{C}$ near the surface to $-5.8^{\circ} \mathrm{C}$ at $6 \mathrm{~m}$ and then uniformly increased to $-0.2^{\circ} \mathrm{C}$ at $30 \mathrm{~m}$.
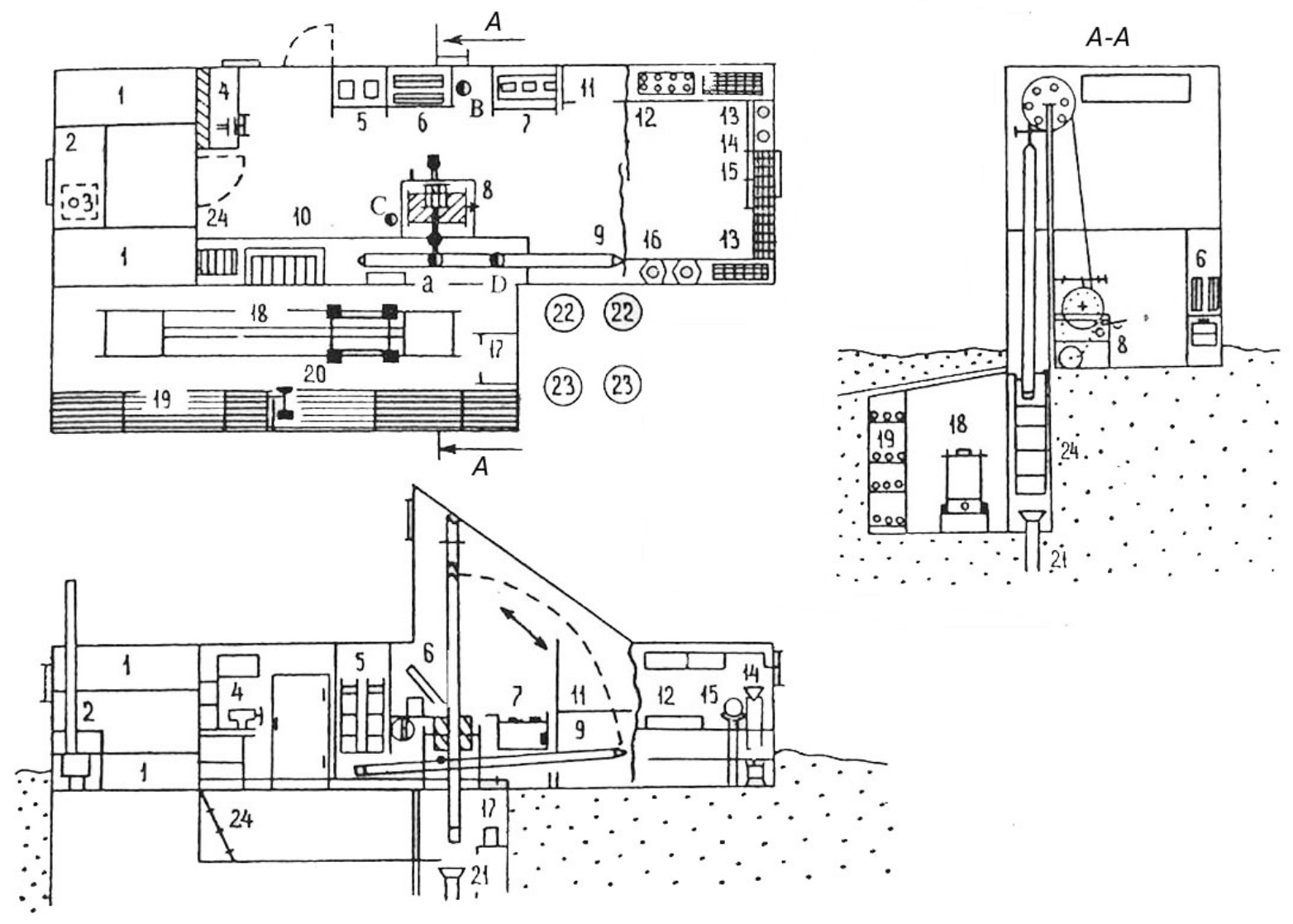

Figure 32. Drilling complex on Austfonna, Spitsbergen (from Anonymous author 1986 and Arkhipov et al. 1987): (1) bunks; (2) table; (3) solar heating; (4) metal-working bench; (5) apparatus for measuring gas pressure in the ice and for taking gas samples; (6) electro-thermal plane for preparing thin section; (7) photographic table; (8) drilling winch; (9) drilling rig; (10) instruments for automatically recording parameters from the core; (11) table for cleaning the core; (12) water bath for melting geochemical samples; (13) isotope and geochemical samples; (14) filtering apparatus; (15) mechanical sampler; (16) hydrothermal sampler; (17) balance; (18) apparatus for automatically examining the core; (19) shelves with core; (20) circular saw for cutting core transversely; (21) mouth of borehole; (22) containers for preparing drilling fluid; (23) containers for anti-freeze; (24) stairs; the symbols a, B, C and D are ATED boreholes with corresponding depths of 204.1, 32.4, 53.7, and $60.9 \mathrm{~m}$ respectively. 


\section{6}

\section{Vavilov Glacier (Severnaya Zemlya)}

The testing of the KEMS-112 electro-mechanical drill was continued, with a 151.8-m-deep cored hole from the 13 to 21 May. A modified TELGA 14M thermal drill was used to drill through the 36.9-m permeable ice (Kudryashov et al. 1994; Vasil'yev et al. 1993). The average characteristics in the interval of 52.4-151.8 m were: chip density in the filter $345-430 \mathrm{~kg} / \mathrm{m} 3$; length of run $1.01 \mathrm{~m}$; rate of penetration $28.4 \mathrm{~m} / \mathrm{h}$; and core production rate $16.5 \mathrm{~m}$ /day. Normally, recovered core was in one or two pieces. Owing to a shortage of drilling fluid (TS-1 aviation fuel), the liquid level was kept at a level of $20 \mathrm{~m}$ above the hole bottom. A directional survey tool was carefully calibrated on the surface (Fig. 33). The hole inclination uniformly decreased from $2^{\circ} 30^{\prime}$ at a depth of $37 \mathrm{~m}$ to $30^{\prime}$ at the bottom.

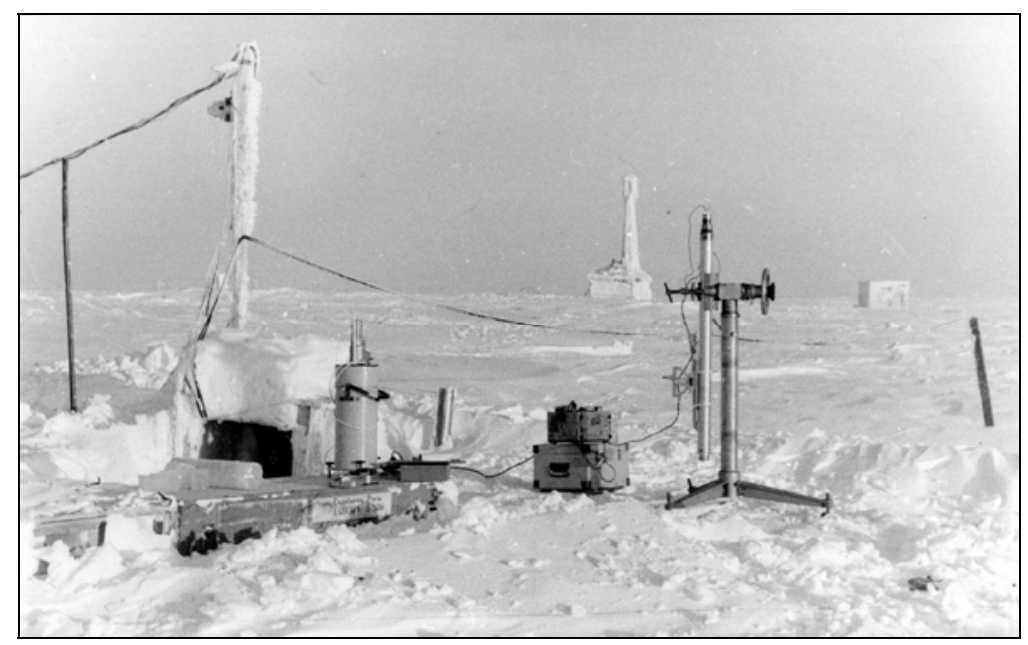

Figure 33. Calibration of directional survey tool (the drilling shelter and workshop are in the background; all living facilities were situated under the glacier surface (Kupol Vavilova, Severnaya Zemlya, photograph by P.G. Talalay 1986)

\section{Akademiya Nauk Glacier $\left(80^{\circ} 30^{\prime} \mathrm{N}\right.$ and $94^{\circ} 50^{\prime} \mathrm{E}$, Severnaya Zemlya, drilling site \#AN1)*}

Akademiya Nauk ice cap is the largest glacier on the Severnaya Zemlya archipelago. It has an area of $5,870 \mathrm{~km}^{2}$ and covers nearly two-thirds of Komsomolets Island. During June-October of 1986, a glaciological expedition from Leningrad State University, IGAS, and AARI carried out research in the central part of the Akademiya Nauk ice cap at an altitude of

\footnotetext{
* see map Fig. 28 and Table 9.
} 
$810 \mathrm{~m}$ a.s.l. (Savatyugin and Zagorodnov 1988). The research included deep core drilling with the ETB-3 anti-freeze thermal drill. Two holes were drilled a distance of 30-35 $\mathrm{m}$ apart. Drilling of the first hole proceeded on a one-shift basis over 42 days and was stopped at a depth of $561 \mathrm{~m}$ because of a shortage of anti-freeze. The average ice core production rate was 13.3 $\mathrm{m} /$ day. During drilling, as a consequence of the inverse temperature gradient, the slush formed plugs, hindering round trips. That is why the drilling fluid was bailed out to a depth of $160 \mathrm{~m}$ (Zagorodnov 1989b). Because of imperfections in the control system, the inclination of the hole reached $25^{\circ}$ at $360 \mathrm{~m}$.

The second hole was drilled to $13 \mathrm{~m}$. In both holes, a temperature survey was carried out (Zagorodnov et al. 1989a; Zagorodnov and Arkhipov $1990 \mathrm{c})$. On the boundary of the active layer at $12.85 \mathrm{~m}$, the temperatures were different: $-9.5^{\circ} \mathrm{C}$ in first hole and in $-8.3^{\circ} \mathrm{C}$ in the second. From this point the temperature decreased to $-14.8^{\circ} \mathrm{C}$ at $160 \mathrm{~m}$. Further down, a 40$\mathrm{m}$ isothermal layer was encountered. Deeper temperatures uniformly increased to $-10.3^{\circ} \mathrm{C}$ at $560 \mathrm{~m}$.

\section{7}

\section{Vavilov Glacier (Severnaya Zemlya)}

The LMI group built a new mobile drilling shelter at the glaciological station Kupol Vavilova (Fig. 34). The construction (Fig. 35) was basically the same as the PBU-3 used in Antarctica. Its hut measured $4.2 \times 9.0 \times 2.5 \mathrm{~m}$ (Kudryashov et al. 1994).

\section{Akademiya Nauk Glacier $\left(80^{\circ} 30^{\prime} \mathrm{N}\right.$ and $94^{\circ} 50^{\prime} \mathrm{E}$, Severnaya Zemlya, drilling site \#AN1)*}

During May-August 1987, the drilling operations in the central part of Akademiya Nauk ice cap were continued (Klement'ev et al. 1988). As in 1986, the ETB-3 anti-freeze thermal drill was used. The old 561-m-deep hole (drilled in 1986) was reopened but could only be restored to a depth of $222 \mathrm{~m}$, which was where the inclination of the old hole significantly increased changing from $3^{\circ}$ at $200 \mathrm{~m}$ to $22^{\circ}$ at the bottom (Zagorodnov, personal communication). The new hole from $222 \mathrm{~m}$ was started without use

\footnotetext{
* see map Fig. 28 and Table 9.
} 
of a whip-stock and reached bedrock at a depth of $761 \mathrm{~m}$. The true vertical depth of the hole was estimated to be $720 \pm 10 \mathrm{~m}$.

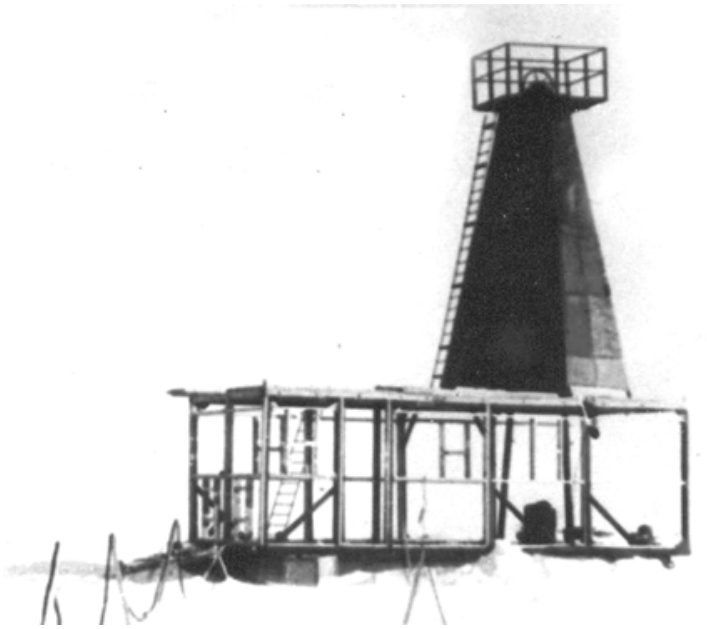

Figure 34. Drilling shelter construction at glaciological station Kupol Vavilova, Severnaya Zemlya (photograph by V.V. Ufaev, 1987).

\section{Austfonna (Nordaustlandet, Spitsbergen, drilling site \#S11)*}

In anticipation of the water inflow problem, the drilling site was chosen on the ice-divide area, $2 \mathrm{~km}$ to the south of the camp built in 1985 (Zagorodnov et al. 1988). The position of the new site was $79^{\circ} 51^{\prime} \mathrm{N}$ and $24^{\circ} \mathrm{O} 8^{\prime} \mathrm{E}$, the altitude was $780 \pm 20 \mathrm{~m}$ a.s.l. From the 2 to 23 June, a $566.7-\mathrm{m}$-deep hole was drilled to bedrock. The thermal ETB-3 anti-freeze drill was used. V.S. Zagorodnov, S.M. Arkhipov, P.A. Korol'ev, A.V. Tarusuv, A.S. Sin'kevich, A.V. Evseev, E.K. Karofeld, M.Yu. Varvas, and V.I. Chernysh'ev took part. The drilling was conducted on one-shift (two people) of 10-14 hours. The core production was $30-33 \mathrm{~m} /$ day. To dissolve slush at the top of the fluid column, an additional 5-10 $\mathrm{L}$ of ethanol were poured into the hole every 4-5 days. In total about a $1000 \mathrm{~L}$ of ethanol was used during drilling. Within 4 days after the termination of drilling, the liquid level rose from $80-85 \mathrm{~m}$ to about $60 \mathrm{~m}$. The hole temperature, which was measured within 6 days after the termination of drilling, decreased from $-2^{\circ} \mathrm{C}$ near the surface to $-7^{\circ} \mathrm{C}$ at a depth of $165 \mathrm{~m}$. Further down the temperature increased to $-1.5^{\circ} \mathrm{C}$ at the hole bottom (Zagorodnov and Arkhipov 1990c).

* see map Fig. 29 and Table 10 
In addition to deep anti-freeze drilling, 40 shallow holes were drilled by a hand coring drill on Austfonna in the summer seasons of 1985 and 1987 (Sin'kevich 1990). Normally, the depths of shallow holes were in the range of 7-10 $\mathrm{m}$ except one that was $18.6 \mathrm{~m}$.

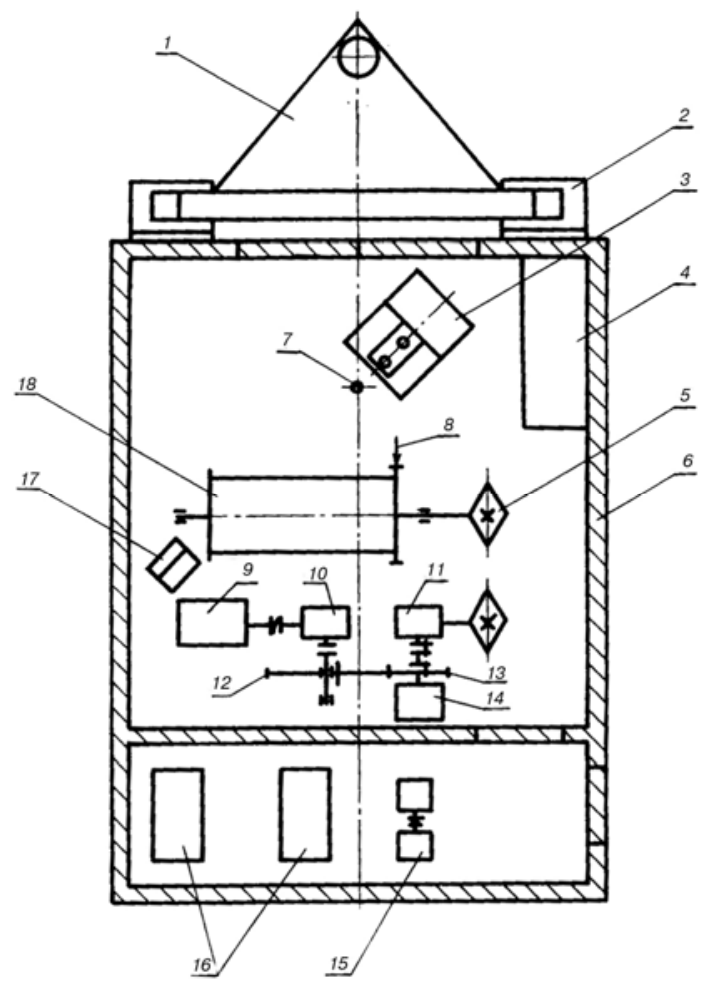

Figure 35. Plan of drilling shelter at glaciological station Kupol Vavilova, Severnaya Zemlya: (1) hitching device; (2 sledge; (3) assembling/disassembling device; (4) joiner's bench; (5) chain-drive; (6) shelter; (7) borehole; (8) hand brake; (9) electric motor; (10) worm gear reducer; (11) gear box; (12), (13) gear and clutch; (14) electric motor; (15) motor-generator; (16) diesel fuel; (17) control desk; (18) winch (from Kudryashov et al., 1994)

\section{Garabashi Glacier (Elbrus, Central Caucasus, drilling site \#C6)*}

Garabashi Glacier is typical of the southern Elbrus slope. At the end of August 1987, two holes were drilled by specialists of the Elbrus Glaciological Party of IGAS on Garabashi Glacier (3950 m a.s.l.) using a thermo-electric point to 73.2 and $77.7 \mathrm{~m}$ (Bazhev et al. 1988; Zagorodnov et al, 1991). Both holes reached bedrock. On the basis of the penetration rate, the thickness of the firn zone was estimated to be $24 \mathrm{~m}$. During drilling, the water levels in the holes were at $23 \mathrm{~m}$ and didn't change when the holes reached bedrock. The glacier was temperate all the way down and was close to the

* see map Fig. 21 and Table 7. 
melting point, which means that it was in a water saturated state. Also at this time, a 23.6-m-deep hole was made by a mechanical hand coring drill.

\section{8}

\section{Vavilov Glacier (Severnaya Zemlya)}

Further testing of the KEMS-112 electro-mechanical drill produced a cored hole $461.6 \mathrm{~m}$ deep, which penetrated the glacier (Bobin et al. 1988;

Kudryashov et al. 1989, 1991, 1993, 1994; Vasiliev et al. 1989, 1993a; Vasiliev and Talalay 1992; Blinov et al., 1994). A modified TELGA-14M thermal drill was used down to $32.2 \mathrm{~m}$ to drill through the permeable upper layer. Down to $101.3 \mathrm{~m}$, the drilling was carried out with the core barrel and the chip chamber made up of tubing with an OD of $127 \mathrm{~mm}$ and a drill head with an OD of $132 \mathrm{~mm}$. To accommodate the tubing, a special adaptor pipe was screwed into the lower end of the gear reducer. This configuration provided an increase in the core diameter and a decrease in trip time (the diameter of the upper part of the drill was still $108 \mathrm{~mm}$ ). Moreover the total drill length became shorter because the ratio between the length of the chip chamber and core length was nearly 1.5 instead of 1.8 for a core barrel with an OD of $108 \mathrm{~mm}$.

The average penetration rate in ice was $21 \mathrm{~m} / \mathrm{hr}$ at a down-hole axial drill load of $200 \mathrm{~N}$. The average core length was around $1 \mathrm{~m}$ per run. The chip density in the filter was in the range of $360-496 \mathrm{~kg} / \mathrm{m}^{3}$. A $2.28-\mathrm{m}$ subglacial core was retrieved. Mineral materials included red-brown siltstones, sandstones, and mudstones (Fig. 36). In the sub-glacial rock, the penetration rate decreased to $1.5 \mathrm{~m} / \mathrm{hr}$ at an axial load of $1200 \mathrm{~N}$. Inclinometer readings revealed a $3.0-3.8^{\circ}$ inclination in the first $100 \mathrm{~m}$, decreasing to $2.5^{\circ}$ between 150 to $461 \mathrm{~m}$. The hole temperature increased uniformly from $-11^{\circ} \mathrm{C}$ at $40 \mathrm{~m}$ to $-6^{\circ} \mathrm{C}$ at the hole bottom. The average temperature gradient was $0.012^{\circ} \mathrm{C} / \mathrm{m}$, but in the interval of $140-260 \mathrm{~m}$, an anomaly of $0.015^{\circ} \mathrm{C} / \mathrm{m}$ was observed.

\section{Garabashi Glacier (Elbrus, Central Caucasus, drilling site \#C6)*}

The drilling operations on Garabashi Glacier were continued (Bazhev et al. 1988; Zagorodnov et al. 1991). Two holes were drilled to 76.7 and $76.0 \mathrm{~m}$ using the ETB-3 anti-freeze thermal drill. The first hole was drilled from

\footnotetext{
* see map Fig. 21 and Table 7.
} 
23-28 May and the second one in 10 days. Both holes reached bedrock. Because of limited power $(\approx 2 \mathrm{~kW})$, the rate of penetration was half of that normally attainable with the ETB-3 drill. Drilling operations were complicated by water freezing on the hole walls at 2-4 $\mathrm{m}$, where the minimum hole temperature $\left(-6^{\circ} \mathrm{C}\right)$ was observed. During drilling the water level in the first hole dropped in proportion to the recovered core and 3 days after the termination of drilling it rose to the firn-ice transition depth at $24 \mathrm{~m}$. The water level in the second hole, situated close to the first hole, was stable at a depth near $24 \mathrm{~m}$ during drilling, which indicated that both holes were hydraulically connected. The distance between holes is not known.

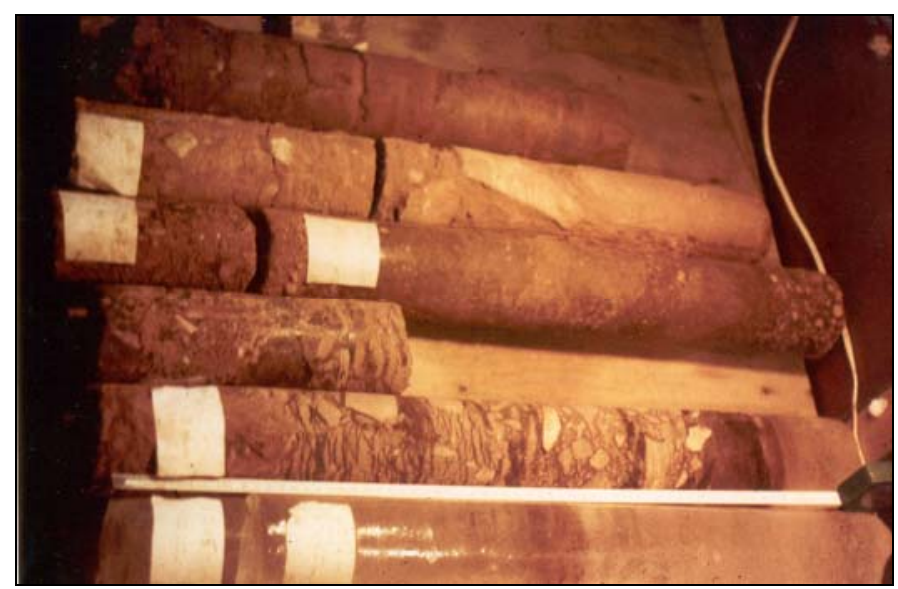

Figure 36. Sub-glacial core from 461.6-m-deep hole at Kupol Vavilova, Severnaya Zemlya (photograph by N.I.Vasiliev, 1988).

\section{9-1990: South Inylchek Glacier (Central Tien Shan, drilling site \#CA5)}

Central Tien Shan (area of Pobeda Peak) is the highest and most difficult to reach area of Tien Shan mountain system. South Inylchek Glacier begins from the few huge erosion cirque firn basins in proximity to the highest Tien Shan point, Pobeda Peak (7439 m a.s.l.) and it is the largest glacier of Tien Shan. The length of South Inylchek Glacier is $60.5 \mathrm{~km}$ and its area is $567.2 \mathrm{~km}^{2}$ (Dolgushin and Osipova 1989). To study the glacial runoff regime of South Inylchek Glacier, members of the IGAS, in collaboration with the Scott Polar Research Institute, University of Cambridge, UK, drilled two holes using a PICO (U.S. Polar Ice Coring Office) hand coring drill (hole depth $30 \mathrm{~m}$, core diameter $98 \mathrm{~mm}$ ) and a light-weight thermal coring drill of the MTBS type designed by the LMI (hole depth of $21 \mathrm{~m}$ ) (V.

\footnotetext{
* see map Fig. 23 and Table 7.
} 
Aizen, personal communication; Aizen et al. 1993). The drilling site was situated at $42^{\circ} 12^{\prime} \mathrm{N}$ and $80^{\circ} 14^{\prime} \mathrm{E}$ at an altitude of $6148 \mathrm{~m}$ a.s.l. The ice temperature at a depth of $10 \mathrm{~m}$ was $-21^{\circ} \mathrm{C}$.

1990

Grigor'ev Glacier (Terskei Alatau, Internal Tien Shan, drilling site \#CA6)*

The first cooperative glaciological research program between the former USSR and the United States on ice caps in the Soviet Central Asia was conducted during July and August 1990 under the auspices of the U.S. National Science Foundation (NSF) (Arkhipov et al. 1996, Tompson et al. 1997). Grigor'ev Glacier $\left(41^{\circ} 58^{\prime} \mathrm{N}\right.$ and $77^{\circ} 55^{\prime} \mathrm{E}$; summit elevation $4660 \mathrm{~m}$ a.s.l.) is situated on the south slope of Terskei Alatau, it has a length of 4 $\mathrm{km}$ and an area of $8.3 \mathrm{~km}^{2}$. Ice core samples were collected from two holes down to 20 and $16.5 \mathrm{~m}$ on the summit of Grigor'ev Glacier. The hole temperature rapidly decreased from $0^{\circ} \mathrm{C}$ near the surface to $-5^{\circ} \mathrm{C}$ at $5 \mathrm{~m}$ and then increased uniformly to $-2.3^{\circ} \mathrm{C}$ at $20 \mathrm{~m}$.

\section{Bolshoi Azau Glacier (Elbrus, Central Caucuses, drilling site \#C7)†}

From 11-13 September 1990, two 17-m-deep holes were drilled in the western part of Bolshoi Azau Glacier at an altitude of $4150 \mathrm{~m}$ a.s.l. by a hand coring auger (Rotataeva et al. 1998). The drill was fixed with 1.5-mlong, gang-mounted rods. The core length was $0.56-0.74 \mathrm{~m}$ and the core diameter was $90 \mathrm{~mm}$.

\section{0-1991}

\section{Loonyi Glacier (Zemlya Aleksandry Island, Franz Josef Land)}

Glaciological investigations on Franz Josef Land were continued by an expedition from IGAS. Loonyi Glacier with an area of $658 \mathrm{~km}^{2}$ on the western most island Zemlya Aleksandry (Sin'kevich et al. 1990; Sinkevich et al. 1991; Macheret et al. 1993). The maximum glacier thickness measured by echo sounding was $312 \mathrm{~m}$. Two holes to depths of 53.6 and $50 \mathrm{~m}$ without core recovery were drilled (the drilling technology wasn't reported; supposedly it was a thermal hot point drill) and temperature observations were carried out. The temperature on the lower boundary of the active

\footnotetext{
* see map Fig. 23 and Table 7.

† see map Fig. 21 and Table 7.
} 
layer at a depth of $10 \mathrm{~m}$ was $-2^{\circ} \mathrm{C}$, and at depths of 20 and $50.6 \mathrm{~m}$ it was 1.7 and $-2.3^{\circ} \mathrm{C}$, respectively.

\section{South-eastern Tibet and Northern Slope of Himalayas}

At this time two expeditions supported by the Academy of Sciences of USSR in collaboration with Chinese glaciologists were carried out in Southeastern Tibet in 1990 and the Northern slope of the Himalayas in 1991 (V. Aizen, personal communication). Two bore-holes were drilled by a Chinese electric thermal coring drill. In South-Eastern Tibet, the hole was drilled to $18 \mathrm{~m}$ and in the Northern Himalayas (Xixipangma Mt.) to $42 \mathrm{~m}$. Both cores were left in China and, after the dissolution of the USSR, Russian-Chinese collaboration has failed.

\section{4: Franz Josef Land}

From May-June 1994, four shallow holes were drilled by hand coring augers in different parts of Franz Josef Land by a joint Russian-U.S. expedition consisting of specialists from the IGAS, Moscow, and the Byrd Polar Research Center, Columbus, Ohio (Mikhalenko et al. 1996):

- $10 \mathrm{~m}\left(80^{\circ} 39^{\prime} 12^{\prime \prime} \mathrm{N}\right.$ and $46^{\circ} 48^{\prime} 33^{\prime \prime} \mathrm{E} ; 382 \mathrm{~m}$ a.s.l.) in the vertex of the Loonyi Ice Cap (Zemlya Aleksandry Island).

- $6 \mathrm{~m}\left(80^{\circ} 37^{\prime} 36^{\prime \prime} \mathrm{N}\right.$ and $58^{\circ} \mathrm{O2}^{\prime} 37^{\prime \prime} \mathrm{E}$; $104 \mathrm{~m}$ a.s.l.) in the vertex of the Gydrografov Ice Cap (Heis Island).

- two 24-m-deep holes $\left(80^{\circ} 47^{\prime} 14^{\prime \prime} \mathrm{N}\right.$ and $\left.63^{\circ} 32^{\prime} 34^{\prime \prime} \mathrm{E}\right)$ on the Vetrennyi Ice Cap (Graham Bell Island).

\section{6: Gorshkov Glacier (Ushkovskii Volcano, Kamchatka)}

The summit of Ushkovskii volcano $\left(56^{\circ} \mathrm{O} 4^{\prime} \mathrm{N} ; 160^{\circ} 28^{\prime} \mathrm{E}, 3903 \mathrm{~m}\right.$ a.s.l.) forms a caldera $4 \mathrm{~km}$ in diameter that is completely covered with a glacier $43 \mathrm{~km}^{2}$ in area (Shiraiwa et al. 2001). Two craters, Gorshkov and Herz, lie beneath the glacier at the highest part of the volcano. The volcano is active, but there are no reliable data on its activity, and only minor fumarolic activity is currently observed. In 1996 1998 the heat and mass transfer of Gorshkov Glacier's active layer was investigated by a Russian-Japanese Cryosphere Research Project (Salamatin et al. 2001). In August 1996, preliminary shallow ice coring was completed to $27 \mathrm{~m}$. The hole temperatures were continuously measured for 1 year. The seasonal fluctuation disap- 
pears at the hole bottom ( $27 \mathrm{~m}$ ), where the snow temperature was constant at $\sim 14.6^{\circ} \mathrm{C}$ throughout the year.

\section{7: Windy Glacier (Graham Bell Island, Vetrennyi Ice Cap, Franz Josef Land)}

During the spring of the 1997 field campaign, two holes were drilled in the central part of Windy Glacier $\left(80^{\circ} 47^{\prime} \mathrm{N}\right.$ and $63^{\circ} 33^{\prime} \mathrm{E}$, app. $500 \mathrm{~m}$ a.s.l.) by a modified lightweight anti-freeze thermal electric drill, m-ATED, within the framework of a U.S.-Russia project on the Franz Josef Land observations (Zagorodnov et al. 1998; Arkhipov et al. 2001). Graham Bell Island is the third largest island $\left(1708.4 \mathrm{~km}^{2}\right)$ of Franz Josef Land. Nearly $71 \%$ of its surface is covered by a large glacier complex, consisting of five interconnected glaciers. The Vetrennyi Ice Cap (by convention in English scientific literature its name is translated as Windy Ice Cap) is the largest (727.9 $\mathrm{km}^{2}$ ) and highest (512 m) glacier of Graham Bell Island and it was chosen as a subject of research and modeling. Logistical support and field studies were conducted by S. Arkhipov, M. Kuznetsov, M. Kunakhovich, V. Mikhalenko, A. Makarov, K. Smirnov and V. Zagorodnov.

The basic operating principle of the m-ATED is similar to the ETB- 3 thermal drill. The body of the m-ATED drill consists of a thin wall stainless steel tube (Fig. 37, Table 8). The ethanol-water solution flows to the kerf through eight 6-mm tubes attached to the outside of the core barrel. This arrangement practically doubles the clearance between the drill and the borehole wall. A wedging mechanism keeps the piston fixed in the low position while lowering the drill in the hole. The piston is set free when the drill touches the hole bottom. The coring head consists of a stainless steel base ring and two identical electrical cable heaters (1.62 $\mathrm{mm}$ OD sheath; $40 \Omega$ ) coiled into a toroidal shape with a $12 \mathrm{~mm}$ outer diameter.

The first hole was drilled to $314.8 \mathrm{~m}$. The quality of the ice core ranged from good to excellent. Normally, the core diameter was $97 \pm 2 \mathrm{~mm}$ and its length was $2 \pm 0.05 \mathrm{~m}$. The average penetration rate was only $2.67 \mathrm{~m} / \mathrm{h}$ (half as much as a ETB-3 thermal drill) because the flow of the ethanolwater solution passing through the drill head carries heat away from the kerf. An average core production rate was $36 \mathrm{~m} /$ day with a one-shift operation. Bore hole inclination was $11^{\circ}$ at a depth of $75 \mathrm{~m}$ and $4^{\circ}$ at a depth of $315 \mathrm{~m}$. The second hole was drilled $1.5 \mathrm{~m}$ from the first hole mainly to obtain cores and was terminated at a depth of $36 \mathrm{~m}$. 


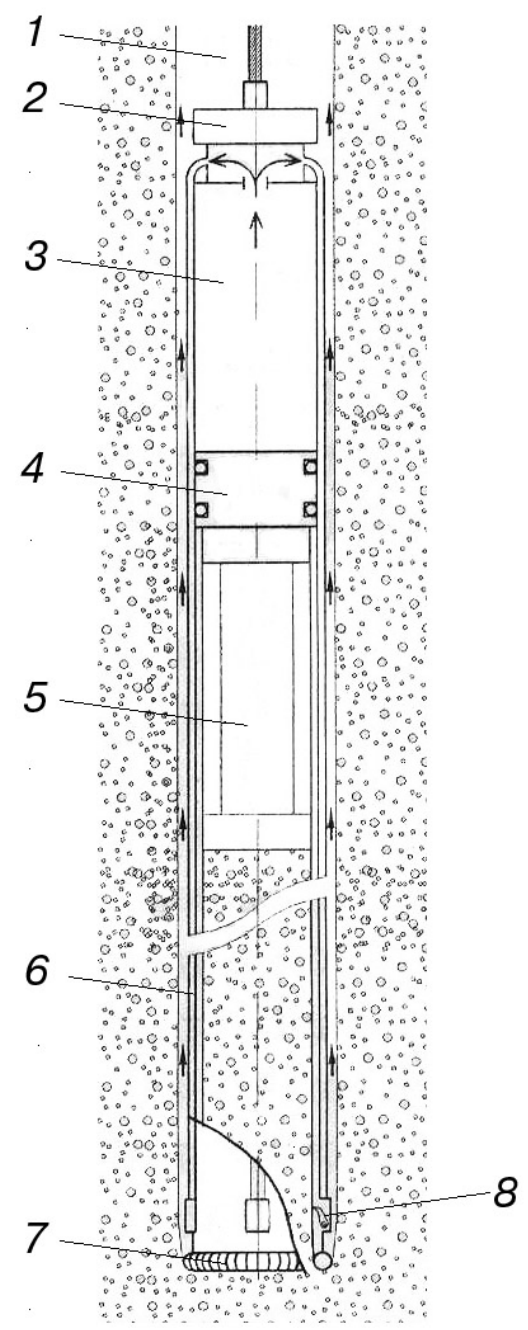

Figure 37. Drill m-ATED: (1) cable; (2) cable termination; (3) unadulterated ethanol-water solution; (4) piston; (5) borehole logger; (6) core barrel; (7) coring head; (8) core catcher (from Zagorodnov et al. 1988).

\section{8: Gorshkov Glacier (Ushkovskii Volcano, 3901 m a.s.l., Kamchatka)}

Full-depth ice coring at Gorshkov Glacier was carried out from 20-30 June 1998 using a D-2 electro-mechanical ice coring drill designed by Geo. Tecs Co., Ltd. (Japan) with the following specifications: outer diameter 125 $\mathrm{mm}$; length $3.1 \mathrm{~m}$; weight $35 \mathrm{~kg}$; core diameter $94 \mathrm{~mm}$; core length $0.8 \mathrm{~m}$; an AC motor 0.6 kW (Prospectus of Geo. Tecs. Co., Ltd.). After a total drilling time of 103 hours, the drilling was stopped at a depth of $211.7 \mathrm{~m}$ (Shiraiwa et al. [1999a] reported a final depth of $212.21 \mathrm{~m}$ ) approximately $28 \mathrm{~m}$ above bedrock (Shiraiwa et al. 2001). A total of 307 drilling runs 
were completed, with penetration rates varying from 9 to $24 \mathrm{~m} / \mathrm{h}$ depending on the cutters and shoes used (Shiraiwa et al. 1999b). The hoisting speed was nearly $0.5 \mathrm{~m} / \mathrm{s}$, the average core length was $0.69 \mathrm{~m}$, and the maximum daily ice core production was $31.4 \mathrm{~m}$ in 10 working hours on 22 June (A. Takahashi, personal communication). There were 183 visible ash layers in the ice cores, and they wore down the cutters very quickly. It was necessary to sharpen cutters continually during operations (it required one person full time for this task). The firn-ice transition was found at a depth of $55 \mathrm{~m}$ (Shiraiwa et al. 1999a). Temperatures at a depth $10 \mathrm{~m}$ and the bottom of the borehole were -15.7 and $-4.2^{\circ} \mathrm{C}$, respectively, showing a linear temperature increase with depth.

\section{9-2001}

\section{Akademiya Nauk Glacier $\left(8_{0.52}^{\circ} \mathrm{N}\right.$ and $94.8^{\circ} \mathrm{E}$, Severnaya Zemlya, drilling site \#AN2)*}

In accordance with an international Russian-German project, a field base on Akademiya Nauk Glacier was established during the spring campaign of 1999 (Vasiliev et al. 2001; Savatyugin et al. 2001; Savatyugin and Shevnina 2003). The preparations and field operations were carried out by specialists of AARI, SPSMI, and AWI (Alfred-Wegener Institute, Bremerhaven, Germany). The drilling site was situated in proximity to the drilling site of 1986-1987. The total weight of the drilling equipment was nearly 4 tons and included a quickly erectable drilling shelter measuring $6 \times 3 \times 2.6$ $\mathrm{m}$ (Fig.38), a 9-m-high mast, a winch with $1000 \mathrm{~m}$ of 15.8 -mm-diameter cable, a 3.2-kW motor, a control desk, an electro-mechanical drill, and auxiliary equipment. In the spring season of 1999 the drilling shelter (Fig. 39) was assembled and core drilling by the KEMS-132 electro-mechanical drill was started (in the above mentioned references this drill is called KEMS-127 as the diameters of the core barrel and chip chamber were 127 $\mathrm{mm}$ ). Basically, it is the same drill that was used at Vostok station (Antarctica) in 1995-1998. The length of the drill was $8 \mathrm{~m}$, and the length of the core barrel was $1.5 \mathrm{~m}$. The OD/ID of the drill head was 135/106 mm. In the first season the hole was drilled to a depth of $53.92 \mathrm{~m}$ by a KEMS drill with reverse air circulation. For this purpose the drill pump was replaced with a vacuum pump. In April of the new millennium season, the dry hole drilling was continued to $109 \mathrm{~m}$, then the bottom part of the hole was filled with a drilling fluid (TS-1 aviation fuel). By the end of the field season (9 May

* see map Fig. 28 and Table 9. 
2000) the hole reached $504.7 \mathrm{~m}$. The drilling operations were stopped because of an increase in air temperature to -5 to $0^{\circ} \mathrm{C}$ at the site of core storage (Srednii Island). The average rate of penetration was nearly $20 \mathrm{~m} / \mathrm{h}$, the average core length was $1.17 \mathrm{~m}$ per run, and core production was 22.6 $\mathrm{m} /$ day with a two-shift operation. The average hauling rate was $0.45 \mathrm{~m} / \mathrm{s}$ at a depth of $500 \mathrm{~m}$. In April-May 2001, drilling of the hole was continued and stopped at $724 \mathrm{~m}$. The last $2 \mathrm{~m}$ was bored through sub-glacial rocks. The hole was almost vertical and the inclination did not exceed $1^{\circ}$.

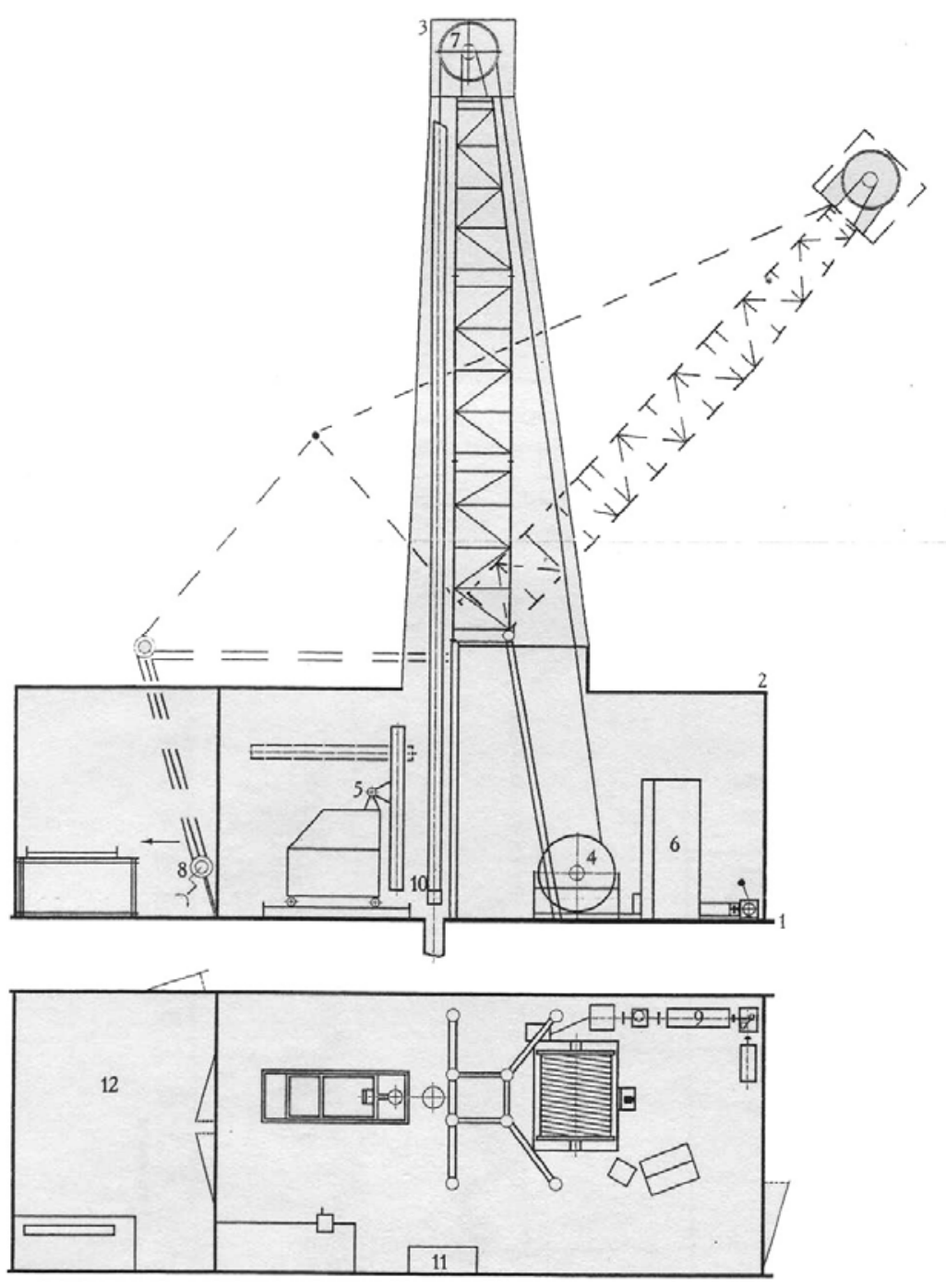

Figure 38. Drilling shelter on Akademiya Nauk Glacier, Severnaya Zemlya: (1) mounting platform; (2) drill house; (3) protective casing; (4) reel with cable; (5) assembling/disassembling device; (6) control desk; (7) mast with roller; (8) device for raising mast; (9) winch drive; (10) electro-mechanical ice core drill; (11) direct current generator; (12) “cold lab" for ice processing (from Savatyugin et al. 2001). 


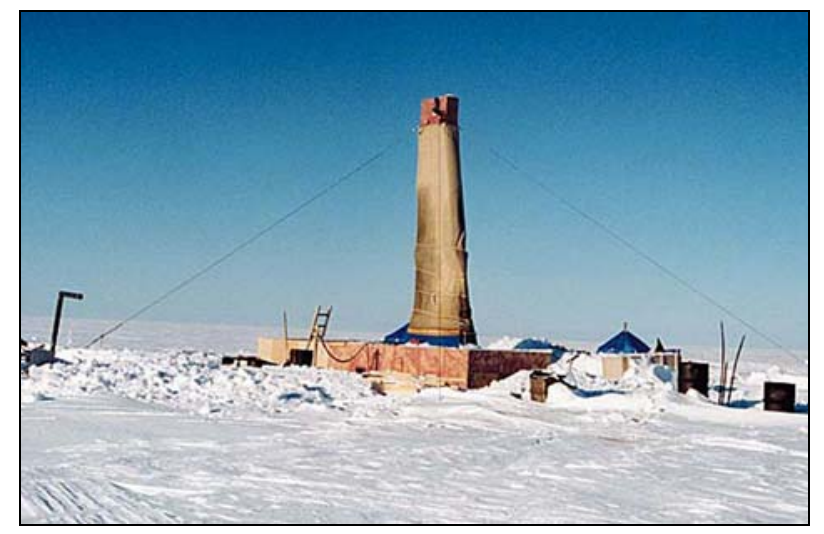

Figure 39. Drilling shelter on Akademiya Nauk Glacier, Severnaya Zemlya (from Savatyugin and Shevnina 2003).

In the 1999 field season, in addition to the deep electro-mechanical drilling, three shallow holes with depths less than $16 \mathrm{~m}$ were made using a hand drill and a portable mechanical drilling rig.

\section{Rvanniy Glacier, South Inylchek (Central Tien Shan)}

Within the international high-altitude ice-core paleo-climatic and environmental change project, mainly supported by the U.S. Department of Energy, the U.S. National Science Foundation , and the U.S. Geological Survey, two holes 165 and $167 \mathrm{~m}$ deep were drilled on Rvanniy Glacier $\left(42^{\circ} 13^{\prime} \mathrm{N}, 80^{\circ} 12^{\prime} \mathrm{E}\right.$; 5100 and $5120 \mathrm{~m}$ a.s.l.) in the summer of 2000 (V. Aizen, personal communication; Kreutz et al. 2003). The ECLIPSE electromechanical drill designed and built by Icefield Instruments Inc. (Canada) was used. Solar panels and batteries were used to power the drill (K. Kruetz, personal communication). The drill produced a 82-mm-diameter core with a typical length of $1 \mathrm{~m}$ (Blake et al. 1998).

\section{0-2001}

\section{Eastern Plateau of Mt. Belukha (Altai Mountains)}

The Altai Mountains are located in the central part of the Eurasian continent and extend from western Siberia to the Gobi Dessert over approximately $2000 \mathrm{~km}$. Nearly 1500 glaciers with a total area of $910 \mathrm{~km}^{2}$ are situated in the region of the Altai mountains group, mainly around the high peaks (Dolgushin and Osipova 1989). The drilling site was situated on the East Belukha snow-firn Plateau ( $49^{\circ} 48^{\prime} \mathrm{N}, 86^{\circ} 32^{\prime} \mathrm{E}$; $3895 \mathrm{~m}$ a.s.l.), which is located on the east side of the summit of Mt. Belukha (4499 m a.s.l.), the highest peak in the Altai mountains. A 138-m-deep ice core was 
drilled by a Swiss-Russian group in the summer of 2000 (V. Aizen, personal communication). A Felics electro-mechanical drill (FS Inventor AG, Switzerland) with a drill head inner/outer diameters of $76 / 103 \mathrm{~mm}$ was used (Ginot et al. 2002).

\section{Sofiyskiy Glacier, Altai Mountains (4947' 10" N, 87 $43^{\prime} 43^{\prime \prime}$ E, 3450 m a.s.I.)}

From 15-24 July 2000, and 6-17 July 2001, a joint Japan-Russia research project hand drilled three holes on Sofiyski Glacier: a 12.3-m-deep hole in 2000, and 9- and a 25.1-m-deep holes in 2001. A KEMS-132 electro-mechanical drill that transported cuttings by an air removal system was also used but was not successful as the firn temperature at shallow depths was $0^{\circ} \mathrm{C}$ creating wet cuttings. The drilling was carried out by SPSMI specialists (Fujii et al. 2002).

\section{3: Western Plateau of Mt. Belukha (Altai Mountains)}

The drilling was carried out on the West Belukha snow-firn Plateau (4100-4150 m a.s.l.) in the Russian Altai Mountains ( $49^{\circ} 49^{\prime} \mathrm{N} ; 86^{\circ} 34^{\prime} \mathrm{E}$ ) (Takeuchi et al. 2004). The West Belukha snow-firn Plateau is located on the west side of the summit of Mt. Belukha. Prior to the drilling in 2003, a 2-year preliminary investigation, carried out in the summers of 2001 and 2002. (V. Aizen, personal communication), mentioned the use of two types of shallow drilling systems used to recover snow-firn cores down to 20$30 \mathrm{~m}$ : PICO, a 100-mm fiberglass hand coring auger, and a Mini-Felics (probably the 5-cm backpack drill), a 82-mm-diameter solar-powered electro-mechanical coring auger.

In 2003 a quonset style tent (Yoshida Tent Co., Japan), $4.5 \mathrm{~m}$ in length, $3.5 \mathrm{~m}$ in width, and $2.25 \mathrm{~m}$ in height, was used for a drilling shelter. The drill system used in this project was a new electro-mechanical drill, which was an improved version of the previous model manufactured by Geo Tecs. Co., Japan. The improvements were made for use on mountain glaciers up to $250 \mathrm{~m}$ deep. The drill system had the following specifications: inner/outer diameter of the drill head $95 / 125 \mathrm{~mm}$; core length $0.55 \mathrm{~m}$; drill length $2.13 \mathrm{~m}$; and power of the driving motor $350 \mathrm{~W}$. Drilling of the first hole was started on 28 July. It took 87.5 hours of actual working time over 7 working days to drill core to the bottom of the glacier. The drilling was stopped at $171.3 \mathrm{~m}$ on 4 August, when the cutter was nicked, probably by hitting a stone. The average ice core production rate was $1.95 \mathrm{~m} / \mathrm{h}$. The 
total number of drilling runs was 325, and the mean core length was 0.486 $\mathrm{m}$. The hole temperature profile was measured every $10 \mathrm{~m}$. The temperature decreased with depth, reaching a minimum of $-15.7^{\circ} \mathrm{C}$ at $70 \mathrm{~m}$, and then increased to $-14 \cdot 2^{\circ} \mathrm{C}$ at the hole bottom. The second hole was started approximately $1 \mathrm{~m}$ south of the first hole on 6 August. It took 12.7 working hours in one day to reach the depth of $48 \mathrm{~m}$. The drilling was stopped at this depth owing to a lack of core boxes. The average production rate of the second drilling was $3.77 \mathrm{~m} / \mathrm{h}$. Most of the cores were not brittle and had a good cylindrical shape. High air temperatures above the melting point in the drilling shelter caused some difficulties. One of the major troubles was slippage of the cutters attributable to the adhesion of cutting chips to the cutters and shoes.

\section{Summary}

Several types of drills have been used over the years in the Soviet and Russian glaciological programs in the Arctic and non-polar regions of the Arctic. They have included hand augers, conventional mechanical drills, percussion drills, jet fired drills, thermo-electric hot points, anti-freeze thermal electric core drills, where the dilute solution remains in the hole, thermal electric core drills for use in dry holes, thermal electric core drills for use in fluid filled holes, a steam thermal drill, and cable suspended electro-mechanical drills. Most of the drilling was conducted by the Institute of Geography Academy of Science (IGAS), the Arctic and Antarctic Research Institute (AARI), and the Leningrad Mining Institute (LMI), later known as the St. Petersburg State Mining Institute (SPSMI). The earliest ice drilling in the Arctic and non-polar glaciers was conducted by IGAS in the mid to late 1950s using manual drilling techniques and equipment designed by E.N. Tsykin.

Non-coring thermo-electric hot points such as the Electroigla ETI-1 and Microteb-1 designed by Morev and Sukhanov, respectively, were used extensively from 1969-1982 and succeeded in penetrating several glaciers.

Anti-freeze thermal electric core drills (ATED), such as the ETB-3 and ETB-5, were used successfully and extensively on Severnaya Zemlya and Sptizbergen Archipelago. A 761-m hole to bedrock was drilled on Akademia Nauk Glacier and a 567-m hole drilled to bedrock in Spitzbergen in 1987. 
A TBZS-152M thermal coring drill was tested on Vavilov Glacier in 1977, reaching bedrock at $462 \mathrm{~m}$. The TBZS type drills were the first drills designed to operate in a fluid-filled hole and included a system for pumping the melt water into a storage tank that was retrieved on each run with the core. An earlier version was used in Antarctica during SAE 18 in 1973 with limited success. Later versions were used to drill several holes at Vostok.

TBSK-93, TBS-93 and TBS93VCh thermal coring drills for use in fluid filled holes were tested on Vavilov Glacier in 1978-79. A later version of the TBS93VCh, the TBS112VCh, was used during SAE 26-30 at Vostok.

The TELGA type thermal drills for drilling dry holes were used in 1981 on Severnaya Zemlya for carbon analysis sampling. It was later used to drill through the permeable zone in preparation for the testing of cable suspended electro-mechanical drills. It had been used as early as SAE-13 (1967-68) and was used extensively in Antarctica.

The KEMS-112 electro-mechanical core drill was first tested in 1984-86 on Vavilov Glacier. A later version KEMS-132 drilled the last hole (5G-1) to a depth of $3623 \mathrm{~m}$ at Vostok from 1995-99. It was also used in 1999-2001 on Akademia Nauk Glacier, Severnaya Zemlya, to drill to bedrock at 724 m.

During the 1990s, cooperative programs with United States, Swiss, English, Japanese, and Chinese researchers and their drills have resulted in numerous cored holes on glaciers in Franz-Josef Land, Kamchatka, Central Tien Shan, and the Altai Mountains. 


\section{References}

Aizen, V. B., E. M. Aizen, V. B. Nesterov, and D. D. Sexton. 1993. A study of glacial runoff regime in Central Tien Shan during 1989-1990. J . Glaciology and Geocryology, 15(3): 442-459.

Aizen, V. B., and V. G. Zakharov. 1989. Balanns massy l'da i skorost' techeniya lednika Davydova v 1984- 1985 gg. [Ice mass balance and flow velocity of Davydov Glacier in 1984- 1985]. Akademiya nauk SSSR. Institut geografii. Materialy gliatsiologicheskikh issledovanii [Academy of Sciences of the USSR. Institute of Geography. Data of Glaciological Studies]. Vol. 67, p.197-202. (Text in Russian with English summary.)

Anonymous. 1962. Soviet Antarctic Expedition Information Bulletin, 4(2): 118.

Anonymous. 1986. Sovetskie glyatsiologicheskie issledovaniya na Vostochnom ledyanom polev 1984- 1985 gg. [Soviet glaciological investigations on Nordaustlandet in 1984- 1985]. Akademiya nauk SSSR. Institut geografii. Materialy gliatsiologicheskikh issledovanii [Academy of Sciences of the USSR. Institute of Geography. Data of Glaciological Studies]. Vol. 56, p.10-26. (Text in Russian with English summary.)

Arkhipov, S. M. 1999. Data Bank Deep Drilling of Glaciers: Soviet and Russian Projects in Arctic, 1975- 1990. Rossiiskaya Akademiya nauk. Institut geografii. Materialy gliatsiologicheskikh issledovanii [Russian Academy of Sciences. Institute of Geography. Data of Glaciological Studies]. Vol. 87, p.229-238. (Text in Russian and English.)

Arkhipov, S. M., V. N. Mikhalenko, and L. Tompson. 1996. Struktura i stratigrafiya deyatel'nogo sloya lednika Grigor'eva na Tyan'-Shane [Structure and stratigraphy of the activelayer of Grigor'ev Glacier on Tien Shan]. Rossiiskaya Akademiya nauk. Institut geografii. Materialy gliatsiologicheskikh issledovanii [Russian Academy of Sciences. Institute of Geography. Data of Glaciological Studies]. Vol. 80, p.68-83. (Text in Russian with English summary.)

Arkhipov, S. M., V. N. Mikhalenko, L. G. Tompson, V. S. Zagorodnov, M. G. Kunakhovich, K. E. Smirnov, A. V. Makarov, and M. P. Kuznetsov. 2001. Stratigrafiya deyatel'nogo sloya lednikovogo kupola Vetrennyi na o.Graham-Bell, Zemlya Ftrantsa-Iosifa [Stratigraphy of the active layer of Windy Ice Cap on Graham Bell Island, FrantzJ osef Land]. Rossiiskaya Akademiya nauk. Institut geografii. Materialy gliatsiologicheskikh issledovanii [Russian Academy of Sciences. Institute of Geography. Data of Glaciological Studies]. Vol. 90, p.169-186. (Text in Russian with English summary.)

Arkhipov, S. M., R. A. Vaykmyae, Ye. V. Vasilenko, V. S. Zagrodnov, Ye. M. Zinger, T. A. Martma, Yu. Ya. Macheret, Ya.-M.K. Punning, O. Yu. Samoylov, S. A. Sin'kevich, M. D. Toots, and L. S. Troitskiy. 1987. Soviet glaciological investigations on Austfonna, Nordaustlandet, Svalbard in 1984-1985. Polar Geography and Geology, 11(1): 25-49. (Text in English.) 
Aver'yanov, V. G. 1968. Vostok Station ten years old. Soviet Antarctic Expedition Information Bulletin, 7(2): 99-100.

Barbash, V. R., L. S. Govorukha, and I .A. Zotiko. 1981. O temperaturnom sostoyanii tolchshi kupola Vavilova [About temperature conditions of Vavilov Ice Cap]. Trudy Arkticheskogo i Antarkticheskogo nauchno-issledovatel'skogo instituta [Transactions of Arctic and Antarctic Research Institute]. Vol. 367, p.54-57. (Text in Russian.)

Bardin, V. I., ed. 1982. Dvadtsat' pervaya Sovetskaya Antarkticheskaya Ekspeditsiya. Zimovotchnie Issledovaniya 1975-1977 gg. Obshchee Opisanye i Nauchnie Rezul'taty [Twenty First Soviet Antarctic Expedition. Wintering Investigations of 1975-1977. General Description and Scientific Results]. Trudy Sovetskoy antarkticheskoy ekspeditsii [Transactions of Soviet Antarctic Expedition]. Vol. 74: 152 (Text in Russian.)

Barkov, N. I. 1970. Preliminary results of ice drilling at Vostok Station. Soviet Antarctic Expedition Information Bulletin, 8(2): 58-60. [Predvaritel'nie rezul'taty bureniya lednikovogo pokrova na stantsii Vostok. Informatsionny Byulleten' Sovetkoj Antarkticheskoj ekspeditsii.] (Text in Russian.)

Barkov, N. I., N. Ye Bobin, and G.K. Stepanov. 1973. Drilling on the Ice Sheet of Antarctica at Vostok Station in 1970. Soviet Antarctic Expedition Information Bulletin, 8(7): 376-379. [Burenie skvazhiny v lednikovom pokrove Antarktidy na stantsii Vostok v 1970 g. Informatsionny Byulleten' Sovetkoj Antarkticheskoj ekspeditsii.] (Text in Russian.)

Barkov, N. I. 1963. Drilling of deep holes in ice by the thermal method. Soviet Antarctic Expedition Information Bulletin, 4(5): 306-307. [Burenie glubokikh skvazhin v lednikovom pokrove metodom protaivaniya. Informatsionny Byulleten' Sovetkoj Antarkticheskoj ekspeditsii.] (Text in Russian.)

Barkov, N. I., K. V. Blinov, M. S. Bugorkov, and D.N. Dmitriev. 1988. Geofizicheskie issledovaniya v skvazhine glubinoi $460 \mathrm{~m}$ na lednike Vavilova (Severnaya Zemlya) [Geophysical investigations in 460-m deep hole on Vavilov Glacier (Severnaya Zemlya)]. Geograficheskie i glyatsiologicheskie issledovaniya v polarnikh stranakh [Geographical and Glaciological Investigations in Polar Regions]. Leningrad, Gidrometroizdat, p. 14-24. (Text in Russian.)

Bazanov, L. D. 1961. Opyt kolonkovogo bureniya na lednikakh Zemli Frantsa-Iosifa [Core drilling experiment on glaciers of Franz Josef Land]. Issledovaniya lednokov i lednikovikh raionov. Akademiya nauk SSSR. Institut Geografii. Mezhduvedomstvennyi Komitet po Provedeniiu MGG [Investigations of Glaciers and Polar Regions. Academy of Sciences of USSR. Interdepartmental Committee on Realization of International Geophysical Year]. Vol. 1, p. 109-114. (Text in Russian with English summary.)

Bazhev, A. B., V. S. Zagorodnov, and O. V. Rototaeva. 1988. Burovye raboty v oblasti pitaniya lednika Garabashi na El'bruse [Drilling operations in the ice-feeding region of Garabashi Glacier at Elbrus]. Akademiya nauk SSSR. Institut geografii. Materialy gliatsiologicheskikh issledovanii [Academy of Sciences of the USSR. Institute of Geography. Data of Glaciological Studies]. Vol. 64, p. 11-12. (Text in Russian.) 
Bazheva, V. Ya., and A. N. Krenke. 1970. Stroenie ledyanoi tolshi Marukhskogo lednika (po rezul'tatan glubokogo burenia letom $1967 \mathrm{~g}$.) [Ice structure of Marukh Glacier (by results of deep drilling on summer of 1967)]. Akademiya nauk SSSR. Institut geografii. Materialy gliatsiologicheskikh issledovanii [Academy of Sciences of the USSR. Institute of Geography. Data of Glaciological Studies]. Vol. 17, p. 288291. (Text in Russian with English summary.)

Bazheva, V. Ya., and T. V. Psar'eva. 1973. Strukturno-tektonicheskoe stroenie tipichnogo dolinnogo lednika Kavkaza [Structural and tectonic formation of typical valley glacier of Caucuses]. Akademiya nauk SSSR. Institut geografii. Materialy gliatsiologicheskikh issledovanii [Academy of Sciences of the USSR. Institute of Geography. Data of Glaciological Studies]. Vol. 22, p. 163-168. (Text in Russian with English summary.)

Blake, E. W., C. P. Wake, and M. D. Garasimoff. 1988. The ECLIPSE drill; a field portable intermediate-depth ice-coring drill. J . of Glaciology, 44(146): 175-178.

Blinov, K. V., N. I. Vasiliev, R. N. Vostretsov,P. G. Talalay, and V. K. Chistyakov. 1994. Eksperimental'nyie burovye i geofizicheskie raboty na lednike Vavilova (arkh. Severnaya Zemlya) [Drilling and geophysical operations on Vavilov Glacier (Severnaya Zemlya archipelago)]. Tretii Mezhdunarodnyi Simpozium “Gornoye Delo v Arktike". Sankt-Peterburg, Oktyabr', 18-21, 1994: Tezisy dokladov [Third International Symposium "Mining in Arctic". Saint Petersburg, 18-21 October 1994: Abstracts]. Saint Petersburg, Saint Petersburg State Mining Institute, p. 162. (Text in Russian.)

Bobin, N. E., N. I. Vasiliev, B. B. Kudryashov, G. K. Stepanov, and P. G. Talalay. 1988. Mekhanicheskoye burenie skvazhin vo l'du [Mechanical Drilling in Ice]. Leningrad, Leningrad Mining Institute. (Text in Russian).

Bobin, N. Ye., and V. F. Fisenko. 1974. Opyt termobureniya skvazhin s otborom kerna v pohodnih usloviyah (Experiment in Thermal Core Drilling on a Traverse). Informatsionny Byulleten' Sovetkoj Antarkticheskoj ekspeditsii [Soviet Antarctic Expedition Information Bulletin], 88: 74-76. (Text in Russian.)

Bogorodsky, V. V., and V. A Morev. 1984. Equipment and technology for core drilling in moderately cold ice. Ice Drilling Technology, Proceedings of the Second International Workshop/ Symposium on Ice Drilling Technology, Calgary, 3031 August 1982, p. 129-132.

Bogorodsky, V. V., V .A. Morev, V. A. Pukhov, and V. M. Yakovlev. 1984. New equipment and technology for deep core drilling in cold glaciers. Ice Drilling Technology, Proceedings of the Second International Workshop/ Symposium on Ice Drilling Technology, Calgary, 30-31 August 1982, p. 139-140.

Brichkin, A. V., S. V. Mikheev, and A. V. Boev. 1967. Ognevoye bureniye lednikov v visokogornikh usloviakh [Flame-jet drilling of glaciers in high-mountain regions]. Izvestiya VGO [Proceedings of All-Union Geographical Society], 99(2): 147-148. (Text in Russian.) 
Bychenkov, E. I., and A. B. Egorov. 1986. Issledovanie rabotosposobnosty kompleksa SSK-59 pri eksperimental'nom burenii skvazhin v Zapadnoy Antarktide (Efficiency of SSK-59 complex at experimental drilling in West Antarctica). Sozdanie i sovershenstvovanie s'emnogo instrumenta dlya geologorazvedochnogo burenia: Sbornik nauchnikh trudov (Designing and Developing a Wire-line Instrument for Prospect Drilling: Collection of Articles). Leningrad: All-Union Research Institute of Prospecting Methods and Techniques (VITR), p. 67-73. (Text in Russian.)

Chistyakov, V. K.. A. M. Skurko, A. A. Zemtsov, N. I. Vasiliev, and G.N. Solov'ev. 1988. Eksperimental'niye burobie raboti na Severnoi Zemle v 1975-1985 gg. [Experimental drilling operations at Severnaya Zemlya in 1975-1985]. Geograficheskie i glyatsiologicheskie issledovaniya v polarnikh stranakh [Geographical and Glaciological Investigations in Polar Regions]. Leningrad: Gidrometroizdat, p.33-42. (Text in Russian.)

Dmitriev, A. N., V. M. Zubkov, A. V. Krasilev, N. G. Menshikov, and V. M. Pashkevich. 1991. Rezul'taty burenia skvazhiny 5G na stantsii Vostok v $1991 \mathrm{~g}$. [Results of drilling hole 5G at Vostok Station in 1991]. Materiyaly Glyatsiologicheskih Issledovaniy [Data of Glaciological Studies], 79: 174-176. (Text in Russian.)

Dmitriev, D. A., R. N. Vostretsov, and I. A. Petukhov. 1978. Deformation of deep holes in the Antarctic glacial cover at Vostok Station [Deformatsiya stenok glubokoy skvazhiny v antarkticheskom lednikovom pokrove na stantsii Vostok]. Byulleten' Sovetkoj Antarkticheskoj Ekspeditsii, 98: 53-57. (Translated from Russian; Cold Regions Bibliography 33-848.)

Dolgushin, L. D., G. B. Osipova. 1989. Ledniki [Glaciers]. Moscow: Mysl'. (Text in Russian.)

Dralkin, A. G., ed. 1963. Chetvortaya Kontinental'naya Ekspeditsiya 1958-1960 gg. Obshchee opisanye i nauchnie rezul'taty [Fourth Continental Expedition of 19581960. General Description and Scientific Results]. Trudy Sovetskoy Antarkticheskoy Ekspeditsii [Transactions of Soviet Antarctic Expedition]. Vol. 26, (Text in Russian.)

Dubrovin, L. I. 1960. Rassol v shel'fovom lednike Lazareva [Brine in the Lazarev Ice Shelf]. Informatsionny Byulleten' Sovetkoj Antarkticheskoj Ekspeditsii [Soviet Antarctic Expedition Information Bulletin], 22: 15-16. (Text in Russian.)

Dyurgerov, M. B., P. A. Korolev, L. N. Manevsky, and B. A. Pukhov. 1987. Issledovaniya srednemnogoletney akkumulyatsii atmosfernikh osadkov v raione observatotii Mirny [Investigation of the average precipitation in the region of Mirny Station]. Informatsionny Byulleten' Sovetkoj Antarkticheskoj Ekspeditsii [Soviet Antarctic Expedition Information Bulletin], 109: 51-57. (Text in Russian.)

Dyurgerov, M .B., V. G. Zakharov, and A. V. Kislov. 1988. Osobennosti snezhno-firnovoi tolshchi i izmenenie kraevikh chastei shel'fovikh lednikov Filchnera i Ronne [Features of snow firn layer and salvages changing of Filchner and Ronne Ice Shelves]. Akademiya nauk SSSR, Institut geografii. Materialy gliatsiologicheskikh issledovanii [Acadamy of Sciences of the USSR, Institute of Geography. Data of Glaciological Studies]. Vol. 63, p. 103-108. (Text in Russian with English summary.) 
Fisenko, V. F., N. E. Bobin, G. K. Stepanov, N. I. Slyusarev, G. N. Solov'ev, and V. K. Chistyakov. 1974. Oslozhneniya i avarii pri glubokom burenii-protaivanii, ih likvidatsiya i preduprezhdenie [Complications and accidents during deep thermal-drilling, their removal and prevention]. Antarktika. Doklady Komissii [The Antarctic. The Committee Reports]. 13: 161-166. (Text in Russian.)

Fujii, Y., T. Kameda, F. Nishio, K. Suzuki, M. Kohno, F. Nakazawa, J. Uetake, L. M. Savatyugin, S. M. Arkhipov, I. A. Ponomarev, and N. N. Mikhailov. 2002. Outline of Japan-Russia joint glaciological research on Sofiyskiy Glacier, Russian Altai Mountains in 2000 and 2001. Bulletin of Glaciological Research. 19:53-58.

Ginot, P., F. Stampfli, I. D. Stampfli, M. Schwikowski, and H. W. Gäggeler. 2002. FELICS, a new ice core drilling system for high-altitude glaciers. Mem. Natl. Inst. Polar Res., Spec. Issue, 56: 38-48.

Golubev, G. N., M. B. Dyurgerov, V. A. Markin, L. B. Berry, L. A. Sukhanov, E. A. Zolotaryev, A .V. Danilina, and Yu. G. Arutyunov. 1978. LednikJ ankuat [J ankuat Glacier]. Leningrad: Gidrometeoizdat. (Text in Russian.)

Golubev, G. N., L. A. Sukhanov, and R. S. Khromov. 1976. Beskernovoye termoelektroburenie i ego primenenie dlya izuchenia stroeniya lednika Jankuat [Full-diameter thermal drilling and its using for structure investigations of Jankuat Glacier]. Akademiya nauk SSSR. Institut geografii. Materialy gliatsiologicheskikh issledovanii [Academy of Sciences of the USSR. Institute of Geography. Data of Glaciological Studies]. Vol.28, p.96-104. (Text in Russian with English summary.)

Golubev, V. N., V. N. Mikhalenko, A. V. Serebrennikov, and O. A. Gvozdik. 1988. Strukturnye issledovaniya ledyanogo kerna Dzhantuganskogo firnovogo plato na Tsentral'nom Kavkaze [Structure observations of the ice core from Dzhantuganskoye Firn Plateau on Central Caucasus]. Akademiya nauk SSSR. Institut geografii. Materialy gliatsiologicheskikh issledovanii [Academy of Sciences of the USSR. Institute of Geography. Data of Glaciological Studies]. Vol. 64, p.25-33. (Text in Russian with English summary.)

Govorukha, L. S. 1981. Issledovaniya Severozemel'skogo glyatsiologicheskogo statsionara [Observations at Severozemel'skii glaciological station]. Trudy Arkticheskogo i Antarkticheskogo nauchno-issledovatel'skogo instituta [Transactions of Arctic and Antarctic Research Institute]. Vol. 367, p.5-8. (Text in Russian.)

Grosvald, M. G., A. N. Krenke, O. N. Vinogradov, V. A. Markin, T. V. Psar'eva, N .G. Razumeiko, and V. L. Sukhodrovskii. 1973. Oledenenie Zemli Frantsa Iosifa [Glaciation of Franz-Josef Land]. Moscow: Nauka. (Text in Russian.)

Ignatov, V. S. 1960a. Study of the structure of snow and firn cover in Antarctica by the thermal method. Soviet Antarctic Expedition Information Bulletin, 3(21): 9-11. [Izuchenie stroeniya snezhno-firnovoy tolschy v Antarktide termicheskim metodom. Informatsionny Byulleten' Sovetkoj Antarkticheskoj ekspeditsii.] (Text in Russian.)

Ignatov, V. S. 196ob. Experiment in the thermal drilling of holes in the ice at Vostok Station. Soviet Antarctic Expedition Information Bulletin, 3(22): 50-52. [Opyt termicheskoy prokhodki ledyanikh skvazhin na stantsii Vostok. Informatsionny Byulleten' Sovetkoj Antarkticheskoj ekspeditsii.] (Text in Russian.) 
Ignatov, V. S. 1962. God na polyuse kholoda [A Year on the Pole of Cold]. Moscow, Geografgiz. (Text in Russian.)

Kapitsa, A. P. 1958. Opyt bureniya l'da v Antarktide s ochistkoi zaboya vozdukhom [Experiment in ice drilling with removal of cuttings by air]. Burenie geologorazvedochnih skvazhin kolonkovim sposobom s ochistkoi zaboya vosdukhom [Prospect Core Drilling with Removal of Cuttings by Air]. Moscow: Gosgeoltechizdat, p. 78-81. (Text in Russian.)

Kartashov, S. N. 1960. Nekotoryie dannye o temperaturnom rezhime lednikovogo pokrova Antarktidy [Some data on the temperature regime of the Antarctic Ice Sheet]. Trudy Sovetskoy antarkticheskoy ekspeditsii [Transactions of Soviet Antarctic Expedition], 10: 107-113. (Text in Russian.)

Kislov, B. V. 1976. Stroenie firnovoi tolchshi i vnutrennee infil'tratsionnoe pitanie lednika Abramova [Structure of firn layer and infiltration alimentation of Abramov Glacier]. Trudy VGI [Transactions of High-mountain Geophysical Institute]. 35: 104-110. USSR (Text in Russian.)

Kislov, B. V., L. N. Manevsky, and L. M. Savatyugin. 1983. Glyatsiologicheskie issledovaniya $\mathrm{v}$ raione stantsii Novolazarevskoy (Glaciological investigations in the region of Novolazarevskaya Station). Trudy Sovetskoy antarkticheskoy ekspeditsii (Transactions of Soviet Antarctic Expedition), 76: 125-130. (Text in Russian.)

Kislov, B. V., and V. K. Nozdryukhin. 1975. Estectvennaya zagryaznennost' firnovoledyanoi tolshi lednika Abramova po dannym kernovogo bureniya [Firn-ice background pollution of Abramov Glacier investigated by core drilling]. Trudy SARNIGMI [Transactions of Middle-East Regional Research HydroMeteorological Institute], 27(108): 86-93. (Text in Russian.)

Klement'ev, O. L., I. M. Korotkov, and V. I. Nikolaev. 1988. Glyatsiologicheskie issledovaniya v 1987-1988 gg. na lednikovykh kupolakh Severnoi Zemli [Glaciological investigations on ice caps of Severnaya Zemlya in 1987-1988]. Akademiya nauk SSSR. Institut geografii. Materialy gliatsiologicheskikh issledovanii [Academy of Sciences of the USSR. Institute of Geography. Data of Glaciological Studies]. Vol. 63, p. 25-26. (Text in Russian.)

Kornilov, N. A., ed. 1987. Dvadtsat' vos'maya Sovetskaya antarkticheskaya ekspeditsiya. Sezonnie issledovaniya 1982-1983 g. (Twenty-eight Soviet Antarctic Expedition. investigations during the 1982-1983 season). Trudy Sovetskoy antarkticheskoy ekspeditsii (Transactions of Soviet Antarctic Expedition), 82. (Text in Russian.)

Korotkevich, Ye. S. 1966. Ten years of soviet research in the Antarctic (1956-1966). Soviet Antarctic Expedition Information Bulletin, 6(2): 74.

Korotkevich, Ye. S., and B. B. Kudryashov. 1976. Ice sheet drilling by Soviet Antarctic Expeditions. Ice Core Drilling, Proceedings of the First International Workshop on Ice Core Drilling, Univ. Nebraska, Lincoln, 28- 30 August 1974, p. 63-70.

Korotkevich, Ye. S., L. M. Savatyugin, and V. A. Morev. 1978. Through drilling a shelf glacier in the region of Novolazarev Station [Skvoznoye burenie shelfovogo lednika v raione stantsii Novolazarevskoy]. Soviet Antarctic Expedition Bulletin, 98: 49-52. (Translated from Russian, Cold Regions Bibl. 35-1057.) 
Korotkevich, Ye. S., ed. 1965. Pyataya kontinental'naya ekspeditsiya 1959-1961 gg. Obshchee opisanye [Fifth Continental Expedition of 1959-1961, general description]. Trudy Sovetskoy Antarkticheskoy Ekspeditsii (Transactions of Soviet Antarctic Expedition), 36. (Text in Russian.)

Koryakin, V. S. 1981. Marshrutami glyatsiologa [Routes of Glaciologist]. Moscow: Mysl'. (Text in Russian.)

Kotlyakov V. M., ed. 1985. Glyatsiologiya Shpitsbergena [Glaciology of Spitsbergen], Moscow: Nauka. (Text in Russian.)

Kovalenko, V. I., B. S. Moiseev, and E. A. Zagrivny. 1981. Burenie-protaivanie skvazhiny na stantsii Vostok-1 [Bore-hole drilling by melting at Station Vostok-1]. Trudy Sovetskoy antarkticheskoy ekspeditsii (Transactions of Soviet Antarctic Expedition), 73: 112-116. (Text in Russian.)

Kravchenko V. V. 1984. Bureniye ledyanikh massivov nebol'shoi moshnosti [Drilling through massive ice of small thickness]. Akademiya nauk SSSR. Institut geografii. Materialy gliatsiologicheskikh issledovanii [Academy of Sciences of the USSR. Institute of Geography. Data of Glaciological Studies]. Vol. 50, p. 161164. (Text in Russian with English summary.)

Krenke, A. N., V. M. Menshutin, A. P. Voloshina, V. D. Panov, V. Ya. Bazhev, V. Ya. Bazheva, V. A. Balaeva, O. N. Vinogradov L. S. Voronina, I. S. Garelik, N. V. Davidovich, N. M. Dubinskaya, Yu. Ya. Macheret, G. P. Moiseeva, T. V. Psar'eva, T. Yu. Tyulina, V. S. Freidlin, I. F. Khmelevskoi, L. P. Chernova, and O. V. Shadrina. 1988. Lednik Marukh (Zapadnyi Kavkaz) [Marukh Glacier (West Caucasus)]. Leningrad: Gidrometeoizdat. (Text in Russian.)

Kreutz, K. J., C. P.Wake, V. B. Aizen, L. D. Cecil, H-A. Synal. 2003. Seasonal deuterium excess in a Tien Shan ice core: influence of moisture transport and recycling in Central Asia. Geophysical Research Letters, 30(18): 1922.

Kruchinin, Yu. A. 1965. Shel'foviye ledniki Zemly Korolevy Mod (Ice Shelves of The Droning Maud Land). Leningrad: Gydrometeoizdat. (Text in Russian.)

Kudryashov, B. B. 1989. Soviet experience of deep drilling in Antarctica. Proceedings of the First International Symposium on Mining in the Arctic, Fairbanks, 17- 19 July 1989, p. 113-122.

Kudryashov, B. B., an A. M. Yakolev. 1983. Drilling in the Permafrost [Burenie Skvazhin v Merzlykh Porodakh]. Moscow: Nedra Publishers. (Translated for the Division of Polar Programs, NSF, TT 87-001-10, 1990.)

Kudryashov, B. B., V. F. Fisenko, G. K. Stepanov, and N. E. Bobin. 1973a. Opyt burenya ledyanogo pokrova Antarktidy [Experience of drilling in Antarctic Ice Sheet]. Antarktika. Doklady Komissii [The Antarctic. The Committee Reports], 12, 145152. (Text in Russian.)

Kudryashov, B. B., N. E. Bobin, N. I. Slyusarev, G. K.. Stepanov, V. F. Fisenko, and V. K. Chistyakov. 1973b. Teoriya i praktika bureniya-protaivaniya v Antarktide [Theory and practice of thermal drilling in Antarctica]. Materiyaly Glyatsiologicheskih Issledovaniy [Data of Glaciological Studies], 22, 71-77. (Text in Russian.) 
Kudryashov, B. B., V. K. Chistyakov, V. G. Vartykyan. 1975. Rezul'taty issledovanyi i razrabotok po glubokomu bureniyu-protaivaniyu vo l'dah Antarktidy [Investigation and designing results of deep drilling-melting in ice of Antarctica]. Fysicheskie protsessy gornogo proizvodstva. Mezhvuzovsky sbornik, Vipusk 1 [Physical Processes in Mining. Inter-institution Collection of Articles, Issue 1]. Leningrad: Leningrad Mining Institute Press, p. 111-116. (Text in Russian.)

Kudryashov, B. B., V. K. Chistyakov, and N. E. Bobin. 1977. Burenie skvazhin teplovim sposobom v lednikovom pokrove Antarktidy [Bore-hole Thermodrilling in Antarctic Ice Sheet]. Moscow: VIEMS.

Kudryashov, B. B., S. S. Abyzov, N. E. Bobin. 1978. Otbor prob dlya mikrobiologicheskih issledovaniy glubokih gorizontov lednikovoi tolschi na stantsii Vostok [Microbiological sampling from deep layers of ice sheet at Vostok Station]. Informatsionny Byulleten' Sovetkoj Antarkticheskoj ekspeditsii [Soviet Antarctic Expedition Information Bulletin], 98: 58-62. (Text in Russian.)

Kudryashov, B. B., V. K. Chistyakov, N. E. Bobin, and A. M. Skurko. 1983a. Osobennosty tekhnologii bureniya-plavleniya glubokih zalitykh nizkotemperaturnoi zhidkost'yu skvazhin v tsentral'nikh raionah Antarktidy [Peculiarities of drilling by melting technology of deep holes filled with a low-temperature liquid in central Antarctica]. Fysicheskie protsessy gornogo proizvodstva. Teplofizicheskie protsessy v gornoi technologii: sbornik trudov. [Physical Processes in Mining. Thermal Physical Processes in Mining Technology. Collection of Articles]. Leningrad: Leningrad Mining Institute Press, p. 59-68. (Text in Russian.)

Kudryashov, B. B., V. K. Chistyakov, and, V. A. Morev. 1983b. Burenie lednikovogo pokrova Antarktidy teplovym sposobom [Thermal drilling in Antarctic Ice Sheet]. 25 let Sovetskoi Antarkticheskoi Ekspeditsii [25th Anniversary of the Soviet Antarctic Expedition]. Leningrad: Gydrometeoizdat, p. 138-149. (Text in Russian.)

Kudryashov, B. B., N. E. Bobin, and G. K. Stepanov. 1983c. Burovoy kompleks dlya prokhodky skvazhin na shel'fovikh lednikakh Antarktidy [Complex for drilling in Antarctic Ice Shelves]. Razrabotka i sovershenstvovanie tekhnologii almaznogo burenia v slozhnikh gorno-geologicheskikh usloviakh: Sbornik nauchnikh trudov [Design and Development of Diamond Drilling Systems Under Complex Mining and Geological Conditions: Collection of Articles]. Moscow: Souzgeotechnika, p. 76-81. (Text in Russian.)

Kudryashov, B. B., V. K. Chistyakov, E. A. Zagrivny, and V. Ya. Lipenkov. 1984a. Preliminary results of deep drilling at Vostok Station, Antarctica 1981-82. Ice Drilling Technology, Proceedings of the Second International Workshop and Symposium on Ice Drilling Technology, Calgary, 30- 31 August 1982, p. 123124.

Kudryashov, B. B., V. K. Chistyakov, and N. E. Bobin. 1984b. Problema bureniya glubokih skvazhin v tsentral'nih raionakh Antarktidy [Problems of deep drilling in Central Antarctica]. Materiyaly Glyatsiologicheskih Issledovaniy [Data of Glaciological Studies], 51: 168-172. (Text in Russian.) 
Kudryashov, B. B., N. E. Bobin, S. P. Zhigalev, and G. K. Stepanov. 1988. Osobennosti mekhanicheskogo burenia skvazhin na shel'fovikh lednikah Antarktidy [Peculiarities of mechanical drilling in Antarctic ice shelves]. Antarktika. Doklady Komissii [The Antarctic. The Committee Reports], 27: 57-61. (Text in Russian.)

Kudryashov, B. B., N. I. Vasiliev, P. G. Talalay, V. V. Ufaev, and G. V. Denisov. 1989. Bureniye skvazhin elektromekhanicheskim snaryadom na gruzonesushchem kabele [Drilling by electromechanical drill hoisting on cable]. Mezhdunarodnyi Simpozium po bureniyu skvazhin v oslozhnennykh usloviyakh. Leningrad, Iyun', 5- 9, 1989: Tezisy dokladov [International Symposium on Drilling in Complicated Conditions. Leningrad, 5- 9 J une 1989: Abstracts]. Leningrad: Leningrad Mining Institute, p.104. (Text in Russian.)

Kudryashov, B. B., V. K. Chistyakov, and V. S. Litvinenko. 1991a. Burenie skvazhin v usloviah izmenenia agregatnogo sostoyanya gornikh porod [Drilling in Conditions of Rock Aggregate Changes]. Leningrad: Nedra. (Text in Russian.)

Kudryashov, B. B., V. K. Chistyakov, N. I. Vasiliev, and P. G. Talalay. 1991b. Burenie skvazhin s otborom kerna elektromekhanicheskim snariadom na gruzonesushchem kabele $\mathrm{v}$ lednikovykh i podlednikovykh porodakh [Drilling boreholes in glacial and subglacial rocks, with core selection by an electromechanical drill on a load-bearing cable]. Akademiya nauk SSSR. Institut geografii. Materialy gliatsiologicheskikh issledovanii [Academy of Sciences of the USSR. Institute of Geography. Data of Glaciological Studies]. Vol. 71, p. 165170. (Text in Russian with English summary.)

Kudryashov, B. B., N. I. Vasiliev, and P. G. Talalay. 1993. Tekhnika i tekhnologiya bureniya skvazhin v lednikakh elektromekhanicheskimi snaryadami na gruzhoneseshchem kabele [Technique and technology of drilling in glaciers by electromechanical drill hoisted on cable]. Yubileinaya nauchnaya konferentsiya, posvyashchyennaya 100-letiyu so dnya rozhdeniya F.A.Shamsheva. SanktPeterburg, Oktyabr', 7- 8, 1993: Tezisy dokladov [J ubilee Scientific Conference Devoted to 100-Years Anniversary of F. A. Shamshev. Saint Petersburg, 7- 8 October 1993: Abstracts]. Saint Petersburg: Saint-Petersburg State Mining Institute, p.16. (Text in Russian.)

Kudryashov, B. B., N. I. Vasiliev, and P. G. Talalay. 1994. KEMS-112 electromechanical ice core drill. International Workshop on Ice Drilling Technology, 4th, Tokyo, 2023 April 1993. Proceedings. (Edited by O. Watanabe.) Tokyo: National Institute of Polar Research. Memoirs. Special issue, No.49, p.138-152.

Kudryashov, B. B., A. V. Krasilev, P. G. Talalay, V. K. Tchistyakov, N. I. Vassiliev, V. M. Zubkov, and V. V. Lukin. 1998a. Drilling equipment and technology for deep ice coring in Antarctica. Proceedings of Seventh Symposium on Antarctic Logistics and Operations; Cambridge, United Kingdom, 6- 7 August 1996. Cambridge: British Antarctic Survey, p. 205-210.

Kudryashov, B. B., V. K. Chistyakov, N. I. Vasiliev, and A. B. Volkov. 1998b. Burenie i issledovanie glubokoy skvazhiny na stantsii Vostok [Drilling and Investigation of a Deep Hole at Vostok Station]. Antarktika. Doklady Komissii [The Antarctic. The Committee Reports], 34: 73-78. (Text in Russian.) 
Kudryashov, B. B., N. I. Vasiliev, V. M. Zubkov, A. V. Krasilev, V. V. Nikishin, and V. K. Chistyakov. 2000. O burenii glubokoy skvazhiny na stantsii Vostok v Antarktide (Drilling of the deep hole at Vostok Station in Antarctica). IV Mezhdunarodny Simposium po bureniyu skvazhin v oslozhnennikh usloviayh: Sbornik dokladov (IVth International Symposium on Drilling under Complicated Conditions: Collection of Reports). St. Petersburg: SPSMI, p. 7-11.

Kudryashov, B. B., N. I. Vasiliev, R. N. Vostretsov, A. N. Dmitriev, V. M. Zubkov, A. V. Krasilev, P. G. Talalay, N. I. Barkov, V. Ya. Lipenkov, and J. R. Petit. 2002. Deep ice coring at Vostok Station (East Antarctica) by an electromechanical drill. Ice Drilling Technology, Proceedings of the Fifth International Workshop on Ice Drilling Technology, Nagaoka, 30October-1 November 2000, p. 91-102.

Lege'nkov, A .P., I. V. Chugui, and N. N. Er'emin. 1974. Rezul'taty izmereniya temperatury ledinogo ostrova dreifuyuchshei stantsii SP-19 [Results of temperature measurements of ice island on drifting station SP-19]. Okeanologiya [Oceanology], 14(4): 619-622. (Text in Russian.)

Macheret, Yu. Ya., S. A. Sin'kevich, L. I. Bobrova, and L. V. Sankina. 1993. Tolchshina i gidrotermicheskoye sostoyanie lednikovogo kupola Loonnyi na Zemle Frantsa Iosifa po dannym radiozondirovaniya [Thickness and hydrothermal condition of Loonnyi Ice Cap on Franz Josef Land according with echo sounding observations]. Rossiiskaya Akademiya nauk. Institut geografii. Materialy gliatsiologicheskikh issledovanii [Russian Academy of Sciences. Institute of Geography. Data of Glaciological Studies]. 77: 97-104. (Text in Russian with English summary.)

Macheret, Yu. Ya., E. V. Vasilenko, A. N. Gromyko, and A. B. Zhuravl'ev. 1984. Radiolokatsionnyi karotazh skvazhiny na lednike Fridtjof [Radar hole logging on Fridtjof glacier]. Akademiya nauk SSSR. Institut geografii. Materialy gliatsiologicheskikh issledovanii [Academy of Sciences of the USSR. Institute of Geography. Data of Glaciological Studies]. 50: 198-203. (Text in Russian with English summary.)

Makarevich, R. G., E. N. Vilesov, R. G. Golovkova, T. Ya. Denisova, and P. F. Shabanov. 1984. Ledniki Tuiuksu [Tuiuksu Glaciers], Leningrad: Gidrometeoizdat, (Text in Russian.)

Manevsky, L. N., V. A. Morev, A. G. Nikiforov, V. A. Pukhov, and V. M. Yakovlev. 1983. Eksperimental'noye burenye na stantsii Komsomol'skoi (Experimental drilling at Komsomolskaya Station). Informatsionny Byulleten' Sovetkoj Antarkticheskoj ekspeditsii (Soviet Antarctic Expedition Information Bulletin), 103: 71-73. (Text in Russian.)

Mikhalenko, V. N., L. G. Tompson, K. Henderson, M. Davis, P.-N. Lin, and J. Dai. 1996. Issledovaniya kerna l'da ostrova Graham Bell, Zemlya Frantsa Iosifa) [Analyses of ice core from Graham Bell Island, Franz Josef Land]. Rossiiskaya Akademiya nauk. Institut geografii. Materialy gliatsiologicheskikh issledovanii [Russian Academy of Sciences. Institute of Geography. Data of Glaciological Studies] 80: 243-247. (Text in Russian with English summary.) 
Mikheev, S. V. 1971. O burenii l'da ognevym sposobom [About ice drilling by flame-jet drilling]. Akademiya nauk SSSR. Institut geografii. Materialy gliatsiologicheskikh issledovanii [Academy of Sciences of the USSR. Institute of Geography. Data of Glaciological Studies]. Vol.18, p.160-163. USSR (Text in Russian with English summary.)

Model, Yu. M. 1959. O glyatsiologicheskih issledovaniaykh v raione observatorii Myrny, provedennikh v kompleksnoy Antarkticheskoi ekspeditsii Akademii Nauk SSSR (Glaciological investigations in the region of the observatory, Mirny carried out by the Complex Antarctic Expedition of Academy of Sciences of USSR). Glyatsiologicheskie Issledovania v period MGG (Glaciological Investigations in the Period of IGY). Issue 1. Moscow, Academy of Sciences of USSR, p. 21-28. (Text in Russian).

Morev, V. A. 1966. Experimental electrothermal ice drilling at Mirny. Soviet Antarctic Expedition Information Bulletin, 56, 61-63. [Opity po bureniyu l'da elektroteplovym sposobom v Mirnom. Informatsionny Byulleten' Sovetkoj Antarkticheskoj ekspeditsii, 56: 52-66] (Text in Russian.)

Morev, V. A. 1972. Ob effektivnosty i ekonomichnosty elektrotermoburovih snaryadov pri burenii materikovogo l'da (Efficiency and economy of electrothermodrills at drilling of continental ice). Trudy Sovetskoy antarkticheskoy ekspeditsii (Transactions of Soviet Antarctic Expedition), 55: 158-165. (Text in Russian.)

Morev, V. A. 1976. Elektrotermobury dlia bureniia skvazhin v lednikovom pokrove [Electric thermal drills for glacier core drilling]. Akademiya nauk SSSR. Institut geografii. Materialy gliatsiologicheskikh issledovanii [Academy of Sciences of the USSR. Institute of Geography. Data of Glaciological Studies]. No. 28, p. 118-120. (Text in Russian with English summary.)

Morev, V. A., and V. A. Shamont'yev. 1972. Experimental ice drilling. Soviet Antarctic Expedition Information Bulletin, 7 (60), 620-621. [Eksperimental'noye burenie lednikovogo pokrova. Informatsionny Byulleten' Sovetkoj Antarkticheskoj ekspeditsii, 78: 102-104. (Text in Russian.)

Morev, V. A., and Yu.V. Raikovsky. 1979. Burenie Antarkticheskogo lednikovogo pokrova $\mathrm{v}$ raione stantsii Novolazarevskaya (Drilling on the Antarctic Ice Sheet in the region of Novolazarevskaya Station). Materiyaly Glyatsiologicheskih Issledovaniy (Data of Glaciological Studies), 37: 198-200. (Text in Russian.)

Morev, V. A., and V. A. Pukhov. 1981. Eksperimental'nye raboty po bureniiu kholodnykh pokrovnykh lednikov termoburovymi snariadami AANII [Using AANII thermodrills in experimental drilling of cold ice sheets]. Trudy Arkticheskogo i Antarkticheskogo nauchno-issledovatel'skogo instituta [Transactions of Arctic and Antarctic Research Institute]. Vol. 367, p. 64-68. Leningrad. (Text in Russian.)

Morev, V. A., V. A. Pukhov, and V. M. Yakovlev. 1981. Burenie skvazhiny na lednike Vavilova, Severnaya Zemlya [Core drilling through Vavilov Glacier, Severnaya Zemlya]. Akademiya nauk SSSR. Institut geografii. Materialy gliatsiologicheskikh issledovanii [Academy of Sciences of the USSR. Institute of Geography. Data of Glaciological Studies] Vol. 40, p. 154-157. USSR (Text in Russian with English summary). Eng. transl. in: Data of glaciological studies: chronicle discussions. (G. A. Avsiuk, Ed.), p. 252-256, 1988. New Delhi: Amerind Publishing Co. 
Morev, V. A., V. A. Pukhov, V. M. Yakovlev, and V. S. Zagorodnov. 1984. Equipment and technology for drilling in temperate glaciers. Proceedings of the Second International Workshop/Symposium on Ice Drilling Technology, Calgary, 3031 August 1982, p. 125-127.

Morev, V. A., O. L. Klement'ev, L. N. Manevskii, Yu. V. Raikovskii, A. I. Tolstoi, and V. M. Yakovlev. 1988. Glyatsio-burobye raboty na lednike Vavilova v 1979-1985 gg. [Ice drilling on Vavilov Glacier in 1979-1985]. Geograficheskie i glyatsiologicheskie issledovaniya v polarnikh stranakh [Geographical and glaciological investigations in polar regions]. Leningrad, Gidrometeoizdat, p. 25-32. (Text in Russian.)

Morev, V. A., L. N. Manevskiy, V. M. Yakovlev, and V. S. Zagorodnov. 1989. Drilling With Ethanol-Based Anti-freeze in Antarctica. Ice Core Drilling, Proceedings of the Third International Workshop on Ice Drilling Technology, Grenoble, 10- 14 October 1988, p. 110-113.

Morev, V. A., L. N. Manevskiy, V. M. Yakovlev, and V. S. Zagorodnov. 1990. Opyt burenia skvazhin s zalivkoi antifriznoi zhidkostyu na osnove etanola v Antarktide (The drilling experience with ethanol-based anti-freeze in Antarctica). Materiyaly Glyatsiologicheskih Issledovaniy (Data of Glaciological Studies), 68: 181-184. (Text in Russian.)

Psar'eva ,T. V., E. N. Tsykin, and T. A. Tsykina. 1968. Eksperimental'naya 150-metrovaya skvazhina ne lednike Bezengi [Experimental 150-m deep borehole on Bezengi Glacier]. Akademiya nauk SSSR. Institut geografii. Materialy gliatsiologicheskikh issledovanii [Academy of Sciences of the USSR. Institute of Geography. Data of Glaciological Studies]. Vol. 14, p.93-97. USSR (Text in Russian.)

Punning, Ya.-M.K., T. A. Martma, K. E. Tyugu, R. A. Vaikmyae, M. Purshe, and F. Pinglo. 1985. Stratifikatiya lednikovogo kerna s Zapadnogo ledyanogo polya na SeveroVostochnoi Zemle [Stratification of ice core from Vestfonna Ice Dome, Nordanstlandet]. Akademiya nauk SSSR. Institut geografii. Materialy gliatsiologicheskikh issledovanii [Academy of Sciences of the USSR. Institute of Geography. Data of Glaciological Studies]. Vol. 52, p. 202-205. (Text in Russian with English summary.)

Raikovsky, Yu. V., O. Yu. Samoilov, N. P. Pron, K. E. Smirnov, and S. M. Arkhipov. 1989. Glyatsiologicheskie issledovaniya na shel'fovom lednike Emery v 1987-1989 gg. (Glaciological Investigations on the Emery Ice Shelf in 1987-1989). Materiyaly Glyatsiologicheskih Issledovaniy (Data of Glaciological Studies), 68, p. 114. (Text in Russian.)

Rototaeva, O. V., I. F. Khmelevskoi, A. B. Bazhev, I. Heintzenberg, M. Stenberg, and J. Pinglo. 1998. Stroenie I khimicheskii sostav deyatel'nogo sloya lednika Bolshoi Azau (Elbrus) v oblasti pitaniya [Structure and chemical composition of active layer of Bolshoi Azau Glacier (Elbrus) in gathering zone]. Rossiiskaya Akademiya nauk. Institut geografii. Materialy gliatsiologicheskikh issledovanii [Russian Academy of Sciences. Institute of Geography. Data of Glaciological Studies] Vol. 84, p. 25-33. Russia (Text in Russian with English summary.) 
Ryumin, A. K., V. K. Nozdryukhin, Yu. N. Emel'yanov, V. A. Morev. 1974. Stroenie lednika Abramova po dannym radiolokatsionnogo zondirovaniya [Structure of Abramov Glacier according with radar sounding]. Trudy SARNIGMI [Transactions of Middle-East Regional Research Hydro-Meteorological Institute]. 14 (95): 2735. (Text in Russian).

Salamatin, A. N., T. Shiraiva, Ya. D. Murav'ev, and M. F. Ziganshin. 2001.

Teplomassoperenos v sezonnom deyatel'nom sloe lednikovogo kupola Gorshkova na vershine vulkana Ushkovskogo, Kamchatka [Heat and mass transfer of Gorshkov Ice Cap active layer on the top of Ushakovskii Volcano, Kamchatka]. Rossiiskaya Akademiya nauk. Institut geografii. Materialy gliatsiologicheskikh issledovanii [Russian Academy of Sciences. Institute of Geography. Data of Glaciological Studies]. Vol. 90, p. 100-106. (Text in Russian with English summary.)

Samoilov, O. Iu., and V. S. Zagorodnov. 1985. Struktura l'da i l'doobrazovanie na subpoliarnom lednike [Ice structure and ice formation on a sub polar glacier]. Akademiya nauk SSSR. Institut geografii. Materialy gliatsiologicheskikh issledovanii [Academy of Sciences of the USSR. Institute of Geography. Data of Glaciological Studies]. Vol. 52, p. 54-61. (Text in Russian with English summary.)

Savatyugin L. M., and V. S. Zagorodnov. 1987. Glyatsiologicheskie issledovaniya na lednikovom kupole Akademii Nauk [Glaciological investigations on Akademiya Nauk Glacier]. Akademiya nauk SSSR. Institut geografii. Materialy gliatsiologicheskikh issledovanii [Academy of Sciences of the USSR. Institute of Geography. Data of Glaciological Studies]. Vol. 61, p. 228. (Text in Russian.)

Savatyugin, L. M. 1980. Glyatsiologeskie issledovaniya na shel'fovom lednike Shekltona (yanvar'-aprel' 1978 g.) (Glaciological investigations on the Shackleton Shelf Glacier [January-April 1978]). Informatsionny Byulleten' Sovetkoj Antarkticheskoj ekspeditsii (Soviet Antarctic Expedition Information Bulletin), 100, 114-118. (Text in Russian.)

Savatyugin, L. M. 2001. Rossyiskie issledovania v Antarktike. (Tridtsat' pervaya SAESorokovaya RAE). Russian Investigations in Antarctica. (Thirty first SAEFortieth RAE), Vol. 3, St.-Petersburg, Gydrometeoizdat. (Text in Russian.)

Savatyugin, L. M., and M. A. Preobrazhenskaya. 1999. Rossyiskie issledovania v Antarktike. (Pervaya-Dvatsataya Sovetskaya Antarkticheskaya Ekspeditsya). Russian Investigations in Antarctica. (First-Twentieth Soviet Antarctic Expedition), Vol. 1, St.-Petersburg, Gydrometeoizdat. (Text in Russian.)

Savatyugin, L. M. , and M. A. Preobrazhenskaya. 2000. Rossyiskie issledovania v Antarktike. (Dvatsat' pervaya-Tridtsataya Sovetskaya Antarkticheskaya Ekspeditsya). Russian Investigations in Antarctica. (Twenty first-Thirtieth Soviet Antarctic Expedition), Vol. 2, St.-Petersburg, Gydrometeoizdat. (Text in Russian.)

Savatyugin, L. M., E. N. Shevnina. 2003. Severnaya Zemlya: 90 let posle otkrytiya [Severnaya Zemlya: 90 years after discovery]. Moscow: Priroda. Vol. 11, p. 5665. (Text in Russian with English summary.) 
Savatyugin, L. M., S. M. Arkhipov et al. 2000. Rossiisko-Germanskie glyatsiologicheskie issledovaniya na Severnoi Zemle i prilegauychshikh ostrovakh [Russian-German glaciological investigations on Severnaya Zemlya and neighboring islands]. Rossiiskaya Akademiya nauk. Institut geografii. Materialy gliatsiologicheskikh issledovanii [Russian Academy of Sciences. Institute of Geography. Data of Glaciological Studies]. Vol. 91, p. 150-162. (Text in Russian with English summary.)

Sedov, O. K., ed. 1981. Dvadtsat' pervaya Sovetskaya antarkticheskaya ekspeditsiya. Sezonnie issledovaniya 1975-1976 g. (Twenty First Soviet Antarctic Expedition. Season Investigations of 1975-1976). Trudy Sovetskoy antarkticheskoy ekspeditsii (Transactions of Soviet Antarctic Expedition), 73. (Text in Russian.)

Sekurov, A. V. 1967. Development of an electrothermal drill unit for drilling in ice and the results of tests at Mirny in 1965-66. Soviet Antarctic Expedition Information Bulletin, 6(3): 275-277. [Osobennosty razrabotky elektrotermoburovogo kompleksa dlya bureniya l'da i rezul'taty ego ispitaniy v Mirnom v 1965/66 g. Informatsionny Byulleten' Sovetkoj Antarkticheskoj ekspeditsii, 60: 59-62. (Text in Russian.)

Shiraiwa, T., Ya. D. Murav'ev, F. Nishino, T. Kameda, A. Takahashi, A. Toyama, and A. A. Ovsyannikov. 1999a. Ledyanoi kern iz bershinnoi kal'dery vulkana Ushkovskii, Kamchatka, Rossia [Ice core from caldera of Uskovskii volcano, Kamchatka, Russia]. Mezdunarodnaya konfrentsya "Monitoring kriosfery." Pushchino, 1999: Tezisy dokladov \{International Conference "Monitoring of Cryosphere." Pushchino, 1999: Abstracts]. p. 98-99. (Text in Russian.)

Shiraiwa, T., F. Nishio, T. Kameda, A. Takahashi, Y. Toyama, Y. D. Murav'yev, and A. A. Ovsyannikov. 1999b. Ice core drilling at Ushkovsky ice cap, Kamchatka, Russia. Seppyo, 61(1): 25-40. (Text in Japanese with English summary.)

Shiraiwa, N., Y. D. Murav'yev, T. Kameda, F. Nishio, Y. Toyama, A. Takahashi, A. A. Ovsyannikov, A. N. Salamatin, and K. Yamagata. 2001. Characteristics of a crater glacier at Ushkovsky volcano, Kamchatka, Russia, as revealed by the physical properties of ice cores and borehole thermometry. J . of Glaciology, 47(158): 423-432. (Text in English.)

Shumskyi, P. A. 1960. Osnovniye rezul'taty issledovanyi Antarkticheskogo lednikovogo pokrova (Main results of the Antarctic Ice Sheet investigations). Vtoraya kontinental'naya ekspeditsiya 1956-1958 gg. Nauchnyie rezul'taty (Second Continental Expedition of 1956-1958. Scientific Results). Trudy Sovetskoy antarkticheskoy ekspeditsii (Transactions of Soviet Antarctic Expedition), 9, 126-170. (Text in Russian.)

Sin'kevich, S. A. 1990. Osobennosti stroeniya I uslovii l'doobrazovaniya v firnovoi tolchshe Vostochnogo ledyanogo polya na Severo-Vostochnoi Zemle [Peculiarities of structure and ice formation conditions in firn zone of Austfonna on Nordaustlandet]. Akademiya nauk SSSR. Institut geografii. Materialy gliatsiologicheskikh issledovanii [Academy of Sciences of the USSR. Institute of Geography. Data of Glaciological Studies]. Vol. 70, p. 29-36. (Text in Russian with English summary.) 
Sin'kevich, S. A., P. A. Korolev, and K. E. Smirnov. 1990. Rekognostsirovochnye issledovaniya na Kupole Loonnyi [Reconnaissance on the Loonyi Ice Cap]. Akademiya nauk SSSR. Institut geografii. Materialy gliatsiologicheskikh issledovanii [Academy of Sciences of the USSR. Institute of Geography. Data of Glaciological Studies]. Vol. 70, p. 121. (Text in Russian.)

Sin'kevich, S. A. , P. A. Korolev, and K. E. Smirnov. 1991. Glaciological reconnaissance on the Loonyi ice cap, Alexandra Land, Franz Josef Land. J . of Glaciology, 37(125): 183-185.

Smirnov, K. E. 1983. Issledovaniya razreza lednikovogo pokrova v raione stantsii Pionerskoy (Vostochnaya Antarktida). (Investigation of the Profile of the Ice Sheet in the Region of Pionerskaya Station [East Antarctica]). Materiyaly Glyatsiologicheskih Issledovaniy (Data of Glaciological Studies), 46: 128-132. (Text in Russian.)

Sukhanov L. A. 1973. Izmerenie moshchnosti gornikh lednikov radiolakatsionnym metodom [Thickness measurements of mountain glaciers by radio-echo method]. Akademiya nauk SSSR. Institut geografii. Materialy gliatsiologicheskikh issledovanii [Academy of Sciences of the USSR. Institute of Geography. Data of Glaciological Studies]. Vol. 22, p. 58-65. USSR (Text in Russian with English summary.)

Sukhanov L .A., V. A. Morev, I. A. Zotikov. 1974. Potativnye ledovye elektrobury [Portable thermo-electric ice drills]. Akademiya nauk SSSR. Institut geografii. Materialy gliatsiologicheskikh issledovanii [Academy of Sciences of the USSR. Institute of Geography. Data of Glaciological Studies]. Vol. 23, p. 234-238. (Text in Russian with English summary.)

Suslov, V. F., A. A. Akbarov, Yu. N. Emel'yanov, V. K. Nozdryukhin, B. V. Kislov, S. I. Inogamova, P. P. Arapov, G. G. Kharitonov, Z. A. Gerasimova, V. A. Heupokoev, and O. Aliev. 1980. Lednik Abramova [Abramov Glacier]. Leningrad: Gidrometeoizdat. (Text in Russian.)

Takeuchi, N., A. Takahashi, J. Uetake, T. Yamazaki, V. B. Aizen, D. Joswiak, A. Surazakov, and S. Nikitin. 2004. A report on ice core drilling on the western plateau of Mt. Belukha in the Russian Altai Mountains in 2003. Polar Meteorol. Glaciol., 18: 121-133. (Text in English.)

Talalay, P. G., and N. S. Gundestrup. 2002. Hole fluids for deep ice core drilling.ice drilling technology. Proceedings of the Fifth International Workshop on Ice Drilling Technology, Nagaoka, 30 October-1 November 2000, p. 148-170.

Tchistiakov, V. K., A. Kracilev, V. Ya. Lipenkov, J. Ph. Balestrieri, C. Rado, and J. R. Petit. 1994. Behavior of a bore hole drilled in ice at Vostok Station. Proceedings of Fourth International Workshop on Ice Drilling Technology, Tokyo, 20-23 April 1993, p. 247-255.

Thompson, L. G., V Mikhalenko, E. Mosley-Thompson, M. Durgerov, P. N. Lin, M. Moskalevsky, M. E. Davis, S. Arkhipov, and J. Dai. 1997. Ice core records of recent climatic variability: Grigoriev and It-Tish Ice Caps in Central Tien Shan, Central Asia. Rossiiskaya Akademiya nauk. Institut geografii. Materialy gliatsiologicheskikh issledovanii [Russian Academy of Sciences. Institute of Geography. Data of Glaciological Studies]. Vol. 81, p. 234- 238. (Text in English.) 
Treshnikov, A. F., ed. 1960. Vtoraya kontinental'naya ekspeditsiya 1956-1958 gg. Obshchee opisaniye (Second Continental Expedition 1956-1958, General Description). Trudy Sovetskoy antarkticheskoy ekspeditsii (Transactions of Soviet Antarctic Expedition), Vol. 8. (Text in Russian.)

Troitskii L. S., E. M. Zinger, V. S. Koryakin, V. A. Markin, and V. I. Mikhalev. 1975. Oledenenie Shpitsbegena (Sval'barda) [Glaciation of Spitsbergen (Svalbard)] . Moscow: Nauka. (Text in Russian.)

Tsykin, E. N. 1962. Metodika izmereniya temperatury lednikov, primenyavshaysya Institutom Geografii AN SSSR v issledovaniyakh Mezhdunarodnogo geofizicheskogo goda [Methods of temperature measurements used by Institute of Geography at researches of International Geophysical Year]. Akademiya nauk SSSR. Institut geografii. Materialy gliatsiologicheskikh issledovanii [Academy of Sciences of the USSR. Institute of Geography. Data of Glaciological Studies]. Vol. 6, p. 113-127. USSR (Text in Russian.)

Tsykin, E.N. (1963a): L'egkie buroviye shtangi dlya bureniya na glubiny 6-7 $\mathrm{m}$ i 12-15 m [Light-weight drill rods for drilling to the depth of 6-7 and 12-15 m]. Akademiya nauk SSSR. Institut geografii. Materialy gliatsiologicheskikh issledovanii [Academy of Sciences of the USSR. Institute of Geography. Data of Glaciological Studies]. Vol. 7, p.135-136. USSR (Text in Russian).

Tsykin, E. N. 1963b. Buroviye shtangi s sharnirnym sochleneniem [Hinged drill rods]. Akademiya nauk SSSR. Institut geografii. Materialy gliatsiologicheskikh issledovanii [Academy of Sciences of the USSR. Institute of Geography. Data of Glaciological Studies]. Vol. 7, p. 137-139. (Text in Russian.)

Tsykin, E. N. 1963c. Burovyie stakany dlya l'da i firna [Core barrels for ice and firn]. Akademiya nauk SSSR. Institut geografii. Materialy gliatsiologicheskikh issledovanii [Academy of Sciences of the USSR. Institute of Geography. Data of Glaciological Studies]. Vol. 7, p. 139-140. (Text in Russian.)

Tsykin, E. N. 1966. Udarno-kanatnoye bureniye lednikov [Cable-churn drilling in glaciers] Akademiya nauk SSSR. Institut geografii. Materialy gliatsiologicheskikh issledovanii [Academy of Sciences of the USSR. Institute of Geography. Data of Glaciological Studies] Vol. 12, p. 239-248. (Text in Russian.)

Tsykin, E. N. 1970. Opisaniye portativnoi burovoi ustanovki dlya udarno-kanatnogo bureniya lednikov na glubiny do $200 \mathrm{~m}$ [Description of portable drilling rig for cable-churn drilling in glaciers up to depths of $200 \mathrm{~m}]$. Akademiya nauk SSSR. Institut geografii. Materialy gliatsiologicheskikh issledovanii [Academy of Sciences of the USSR. Institute of Geography. Data of Glaciological Studies]. Vol. 16, p. 257-262. (Text in Russian.)

Tsykina, G. A., and E.N. Vilesov. 1963. O temperaturnom rezhime lednika Tuiuksu Tsentral'nyi [About temperature regime of the Central Tuiuksu Glacier]. Issledovaniya lednokov i lednikovikh raionov. Akademiya nauk SSSR. Institut Geografii. Mezhduvedomstvennyi Geofizicheskyi Komitet pri Prezidiume AN SSSR [Investigations of glaciers and polar regions. Academy of Sciences of USSR. Interdepartmental Geophysical Committee At Presidium of Academy of Sciences of USSR]. Moscow, Vol. 3, p. 56-66. (Text in Russian.) 
Vartykyan, V. G., V. I. Kovalenko, and B. S. Moiseev. 1977. Opyt iskrivleniya skvazhin v usloviyah Antarktidy (Experience of Bore-hole Deviation in Antarctica). Informatsionny Byulleten' Sovetkoj Antarkticheskoj ekspeditsii (Soviet Antarctic Expedition Information Bulletin), 96: 24- 25. (Text in Russian.)

Vasil'yev, N. I., B. B. Kudrayashov, P. G. Talalay, and V. K. Chistyakov. 1993. Core drilling by electromechanical drill. Polar Record, 29(170): 235-237.

Vasilenko, E. V., A. N. Gromyko, D. N. Dmitriev, and Yu. Ya. Macheret. 1988. Stroenie lednika Davydova po dannym radiozondirovaniya i termobureniya [Structure of the Davydov Glacier according with radio sounding and thermal drilling data]. Akademiya nauk SSSR. Institut geografii. Materialy gliatsiologicheskikh issledovanii [Academy of Sciences of the USSR. Institute of Geography. Data of Glaciological Studies]. Vol. 62, p. 208- 215. (Text in Russian with English summary.)

Vasiliev, N. I., K. V. Blinov, G. V. Denisov, A. N. Markov, P. G. Talalay, and V. V. Ufaev. 1989. Burenie i issledovaniye skvazhiny na lednike Vavilova (Severnaya Zemlya) v 1988 godu [Drilling and logging of the borehole on Vavilov Glacier (Severnaya Zemlya) in 1988]. Akademiya nauk SSSR. Institut geografii. Materialy gliatsiologicheskikh issledovanii [Academy of Sciences of the USSR. Institute of Geography. Data of Glaciological Studies]. Vol. 67, p. 249. (Text in Russian.)

Vasiliev, N. I., and P. G. Talalay. 1992. Kolonkovyi elektromekhanicheskii burovoi snaryad: Konstruktsiya i resul'taty ispytanii [Electromechanical core drill: construction and results of tests]. II Mezhdunarodnyi Simpozium po bureniyu skvazhin v oslozhnennykh usloviyakh. Sankt-Peterburg, Iyun', 2- 7, 1992: Tezisy dokladov [Second International Symposium on Drilling in Complicated Conditions. Saint Petersburg, J une, 2- 7, 1992: Abstracts]. Saint Petersburg, Saint-Petersburg State Mining Institute, p. 120. (Text in Russian.)

Vasiliev, N. I., B. B. Kudryashov, P. G. Talalay, and V. K. Chistyakov. 1993a. Core drilling by electromechanical drill. Polar Record, 29(170): 235-237. (Text in English.)

Vasiliev, N. I., S. P. Zhigalyev, V. M. Zubkov, P. G. Talalay, and V. K. Chistyakov. 1993b. Burenie neglubokikh skvazhin v lednikakh [Shallow drilling in glaciers]. Rossiiskaya Akademiya nauk. Institut geografii. Materialy gliatsiologicheskikh issledovanii [Russian Academy of Sciences of the USSR. Institute of Geography. Data of Glaciological Studies]. Vol. 77, p. 74- 77. (Text in Russian with English summary.)

Vasiliev, N. I., B. B. Kudryashov, V. M. Zubkov, R. N. Vostretsov, A. N. Dmitriev, A. V. Krasilev, L. M. Savatyugin, H. Miller, and D. Fritsche. 2001. Rezul'taty bureniya skvazhiny na lednike Akademii Nauk (Arkhipelag Severnaya Zemlya) [Results of drilling on Akademiya Nauk Glacier (Severnaya Zemlya archipelago)]. V Mezhdunarodnyi Simpozium po bureniyu skvazhin v oslozhnennykh usloviyakh. Sankt-Peterburg, Iyun', 11- 15, 2001: Tezisy dokladov [Fifth International Symposium on Drilling in Complicated Conditions. Saint Petersburg, J une, 11- 15, 2001: Abstracts]. Saint Petersburg, Saint-Petersburg State Mining Institute, p. 9. (Text in Russian.) 
Verkulich, S. R., B. B. Kudryashov, N. I. Barkov, N. I. Vasiliev, R. N. Vostretsov, A. N. Dmitriev, V. M. Zubkov, A. V. Krasiliev, P. G. Talalay, V. Ya. Lipenkov, L. M. Savatyugin, and I. N. Kuz'mina. 2002. Proposal for penetration and exploration of sub-glacial Lake Vostok, Antarctica. Fifth International Workshop on Ice Drilling Technology, Nagaoka, Oct. 30-Nov.1, 2000, p. 245-252.

Vilesov, E. N., and P. F. Shabanov. 1961. Iz opyta bureniya na visokogornikh lednikakh [Drilling experiment on high-mountain glaciers]. Glyatsiologicheskie issledovaniya v period MGG. Zailiiskii i Dzhungarskii Alatau [Glaciological investigations during IGY. Zailiiskii i Dzhungarskii Alatau] Alma-Ata, Izd-vo Akad. nauk Kazakhskoi SSR [Alma-Ata, Publisher: Academy of Sciences of Kazakh Soviet Socialist Republic]. Vol. 1, p.31-35. (Text in Russian with English summary.)

Vinogradov, V. N., S. T. Balesta, M. I. Zubin, and A. I. Farberov. 1981. Glyatsiologicheskie issledovaniya lednika Kozel'skogo v 1975 godu [Glaciological observations on Kazel'skii Glacier in 1975]. Akademiya nauk SSSR. Institut geografii. Materialy gliatsiologicheskikh issledovanii [Academy of Sciences of the USSR. Institute of Geography. Data of Glaciological Studies]. Vol. 41, p. 202- 209. (Text in Russian with English summary.)

Zagorodnov, V. S. 1981. Issledovanie stroeniia i temperaturnogo rezhima shpitsbergenskikh lednikov s pomoshch'iu termobureniia [Using thermal drills in studying temperature regime of Spitsbergen glaciers]. Akademiya nauk SSSR. Institut geografii. Materialy gliatsiologicheskikh issledovanii [Academy of Sciences of the USSR. Institute of Geography. Data of Glaciological Studies]. Vol. 41, p. 196-199. (Text in Russian with English summary.)

Zagorodnov, V. S. 1988. Recent Soviet activities on ice core drilling and core investigations in Arctic region. Bulletin of Glacier Research, 6: 81- 84. (Text in English.)

Zagorodnov, V. S. 1989b. Antifriz-termicheskoe kernovoe burenie arkticheskikh pokrovnykh lednikov [Anti-freeze-thermal core drilling in arctic ice sheets]. Akademiya nauk SSSR. Institut geografii. Materialy gliatsiologicheskikh issledovanii [Academy of Sciences of the USSR. Institute of Geography. Data of Glaciological Studies]. Vol. 66, p. 143-149. USSR (Text in Russian with English summary.)

Zagorodnov, V. S. 1989c. Anti-freeze-thermodrilling of cores in arctic sheet glaciers. International Workshop on Ice Drilling Technology, 3rd, Grenoble, France, Oct. 10- 14, 1988. Proceedings. Ice core drilling (C. Rado and D. Beaudoing,Eds.). Grenoble, France: Centre National de la Recherche Scientifique. Laboratoire de Glaciologie et Geophysique de l'Environnement. France, p.97-109. (Text in English.)

Zagorodnov, V. S., and S. M. Arkhipov. 1990. Studies of structure, composition and temperature regime of sheet glaciers of Svalbard and Severnaya Zemlya: methods and outcomes. Bulletin of Glacier Research, 8: p.19-28. (Text in English.) 
Zagorodnov, V. S., S. M. Arkhipov, A. B. Bazhev, T. A. Vostokova, P. A. Korolyev, O. V. Rototaeva, S. A. Sin'kevitch, and I. F. Khmelevskoi. 1991. Stroenie, sostav i gidrotermicheskii rezhim lednika Garabashi na El'bruse [Structure, composition and hydrothermal regime of the Garabashi Glacier on Elbrus] Akademiya nauk SSSR. Institut geografii. Materialy gliatsiologicheskikh issledovanii [Academy of Sciences of the USSR. Institute of Geography. Data of Glaciological Studies] Vol. 73, p. 109-117. (Text in Russian with English summary.)

Zagorodnov, V. S., S. M. Arkhipov, and Yu. Ya. Macheret. 1985. Rekonstruktsiia uslovii l'doobrazovaniia na subpoliarnom lednike po rezul'tatam issledovanii kerna [Reconstructions of ice-formation conditions on a sub polar glacier from core analyses]. Akademiya nauk SSSR. Institut geografii. Materialy gliatsiologicheskikh issledovanii [Academy of Sciences of the USSR. Institute of Geography. Data of Glaciological Studies]. Vol. 53, p. 36-44. (Text in Russian with English summary.)

Zagorodnov, V. S., O. L. Klement'ev, N. N. Nikiforov, V. I. Nikolaev, L. M. Savatiugin, and V. A. Sasunkevitch. 1990b. Gidrotermicheskii rezhim i l'doobrazovanie v tsentral'noi chasti lednika Akademii Nauk na Severnoi Zemle [Hydrothermal regime and ice formation in the central part of the Akademiya Nauk Glacier, Severnaya Zemlya]. Akademiya nauk SSSR. Institut geografii. Materialy gliatsiologicheskikh issledovanii [Academy of Sciences of the USSR. Institute of Geography. Data of Glaciological Studies]. Vol. 70, p.36-43. (Text in Russian with English summary.)

Zagorodnov, V. S., and O. Iu. Samoilov. 1982a. Glubinnoe stroenie shpitsbergenskikh lednikov [Internal structure of Spitsbergen glaciers]. Akademiya nauk SSSR. Institut geografii. Materialy gliatsiologicheskikh issledovanii [Academy of Sciences of the USSR. Institute of Geography. Data of Glaciological Studies]. Vol. 44, p.58-64. (Text in Russian with English summary.)

Zagorodnov, V. S., O. Iu. Samoilov, Yu. V. Raikovsii, A. V. Tarusov, M. N. Kuznetsov, A. V. Sazonov. 1984. Glubinnoe stroenie lednikovogo plato Lomonosova na o. Zap. Spitsbergen [Deep structure of the glacial Lomonosov Plateau on western Spitsbergen]. Akademiya nauk SSSR. Institut geografii. Materialy gliatsiologicheskikh issledovanii [Academy of Sciences of the USSR. Institute of Geography. Data of Glaciological Studies]. Vol. 50, p.119- 126. (Text in Russian with English summary.)

Zagorodnov, V. S., L. M. Savatiugin, and V. A. Morev. 1989a. Temperaturnyi rezhim lednika Akademii Nauk na Severnoi Zemle [Temperature regime of the Akademiya Nauk Glacier, Severnaya Zemlya]. Akademiya nauk SSSR. Institut geografii. Materialy gliatsiologicheskikh issledovanii [Academy of Sciences of the USSR. Institute of Geography. Data of Glaciological Studies]. Vol. 65, p.134-138. (Text in Russian with English summary.)

Zagorodnov, V. S., S. A. Sin'kevich, and S. M. Arkhipov. 1990a. Gidrotermicheskii rezhim ledorazdel'noi oblasti Vostochnogo ledianogo polia, o. Severo-Vostochnaia Zemlia [Hydrothermal regime of the ice-divide area of Austfonna, Nordaustlandet]. Akademiya nauk SSSR. Institut geografii. Materialy gliatsiologicheskikh issledovanii [Academy of Sciences of the USSR. Institute of Geography. Data of Glaciological Studies]. Vol. 68, p. 133-141. (Text in Russian with English summary.) 
Zagorodnov, V. S., and E. M. Zinger. 1982b. Gliatsiologicheskie raboty na SeveroVostochnoi Zemle [Glaciological investigations on North East Land]. Akademiya nauk SSSR. Institut geografii. Materialy gliatsiologicheskikh issledovanii [Academy of Sciences of the USSR. Institute of Geography. Data of Glaciological Studies]. Vol. 43, p. 30. (Text in Russian.)

Zagorodnov, V. S., E. M. Zinger, L .S. Troitskii, and S. M. Arkhipov. 1988. Zavershenie glubokogo bureniya na Vostochnom ledyanom pole [Completion of deep drilling on Nordaustlandet]. Akademiya nauk SSSR. Institut geografii. Materialy gliatsiologicheskikh issledovanii [Academy of Sciences of the USSR. Institute of Geography. Data of Glaciological Studies]. Vol. 61, p. 184. (Text in Russian.)

Zagorodnov, V. S., and I. A. Zotikov. 1981a. Kernovoe burenie na Shpitsbergene [Core drilling at Spitsbergen]. Akademiya nauk SSSR. Institut geografii. Materialy gliatsiologicheskikh issledovanii [Academy of Sciences of the USSR. Institute of Geography. Data of Glaciological Studies]. Vol. 40, p.157-163. (Text in Russian with English summary.) Eng. transl. in: Data of glaciological studies: chronicle discussions (G.A. Avsiuk, Ed.), p.257-266, 1988. New Delhi: Amerind Publishing Co.

Zagorodnov, V. S., and I. A. Zotikov. 1981b. Vnutrilednikovie kanaly [Englacial channels]. Akademiya nauk SSSR. Institut geografii. Materialy gliatsiologicheskikh issledovanii [Academy of Sciences of the USSR. Institute of Geography. Data of Glaciological Studies]. Vol. 41, p. 200- 202. (Text in Russian with English summary.)

Zagorodnov, V. S., I. A. Zotikov, V. R. Barbash, and B. I. Mikhalyev. 1976. O termoburenii na lednike Obrucheva [Thermal drilling on the Obruchev glacier]. Akademiya nauk SSSR. Institut geografii. Materialy gliatsiologicheskikh issledovanii [Academy of Sciences of the USSR. Institute of Geography. Data of Glaciological Studies]. Vol. 28, p. 112-118. (Text in Russian with English summary.)

Zagorodnov V. S., L. G. Thompson, J. J. Kelley, B. Koci, and V. Mikhalenko. 1998. Antifreeze thermal ice core drilling: an effective approach to the acquisition of ice cores. Cold Regions Science and Engineering, 28(3): 189- 202. (Text in English.)

Zagrivny, E. A., and B. S. Moiseev. 1988. Oslozhneniya i metody ih ustraneniya pri burenii glubokoi skvazhiny na stantsii Vostok (Complications and methods of their removal during deep drilling at Vostok Station). Zapiski Leningradskogo Gornogo Instituta (Transactions of Leningrad Mining Institute), 116: 87- 93. (Text in Russian.)

Zagrivny, E. A., B. S. Moiseev, and A. M. Skurko. 1985. Rezul'taty polevih ispytanyi vysokochastotnogo termoburovogo kompleksa TBS-112VCh pri burenyi glubokoi skvazhiny v nizkotemperaturnom lednikovom pokrove (stantsiya Vostok) (Results of field tests of a high frequency thermal drill TBS-112VCh drilling a deep hole in a low-temperature ice sheet [Station Vostok]). Zapiski Leningradskogo Gornogo Instituta (Transactions of Leningrad Mining Institute), 105: 103-107. (Text in Russian.) 
Zagrivny, E. A., A. A. Zemtsov, Yu. B. Kononov, B. S. Moiseev, P. A. Petukhov, and A. M. Skurko. 1981. Opyt byreniya-plavleniya skvazhin, zalitikh nezamerzayushchey zhidkostyu, v Antarktike i Arktike (Experience of drilling by melting of holes filled with a non-freezing liquid in Antarctica and the Arctic). Zapiski Leningradskogo Gornogo Instituta (Transactions of Leningrad Mining Institute), 86: 79-83. (Text in Russian).

Zagrivny, E. A., A. A. Zemtsov, R. N. Vostretsov, and A. M. Shkurko. 1980. Eksperimental'noe burenie skvazhiny, zalitoi nezamerzayushchei zhidkost'yu (Experimental drilling of a hole filled by a non-freezing liquid). Informatsionny Byulleten' Sovetkoj Antarkticheskoj ekspeditsii (Soviet Antarctic Expedition Information Bulletin), 100: 119-123. (Text in Russian.)

Zagrivnyi, E. A., A. A. Zemtsov, Yu. B. Kononov, B. S. Moiseev, P. A. Petukhov, and A. M. Skurko. 1981. Opyt burenia-plavlenia skvazhin, zalitikh nezamerzayushchey zhidkostiu, $v$ Antarktike i Arktike [Experience of drilling by melting of holes filled by non-freezing liquid in Antarctica and Arctic]. Zapiski Leningradskogo Gornogo Instituta [Transactions of Leningrad Mining Institute]. 86: 79-83. (Text in Russian.)

Zagrivnyi, E. A., Yu. A. Zelentsov, B. B. Kudryashov, N. P. Safronova, V. K. Chistyakov, A. M. Shkurko, and S. G. Luk'yanchenko. 1979. Razrabotka tehkniki i tekhnologii glubokogo bureniya v Tsentral'noi Antarktide, metodov kompleksnikh issledovanii skvazhin i kerna. Otchyet o rabotakh glyatsioburovogo otryada v ekspeditsii A-162 za 1978- 1979 gg. (Otcheyt po khozyastvennomu dogovoru № 1.10.889 s Arkticheskim i Antarkticheskim NII). [Technique and technology development of deep drilling in Central Antarctica and integrated exploration methods of bore holes and core. Research report on operations of glaciologicaldrilling team at expedition A-162 in 1978-1979 (Report on economic agreement № 1.10.889 with Arctic and Antarctic Research Institute)]. Leningrad, Leningrad Mining Institute, Department of Drilling Technology and Technique. (Text in Russian stored in reserves of SPMI.)

Zemtsov, A. A., and N. G. Men'shikov. 1988. Kompleks tekhnicheskikh sredstv dlya otbora prob na uglerodnyi analiz iz ledovikh tolshch [Ice sheet sampling devices for carbon analyzing]. Zapiski Leningradskogo Gornogo Instituta [Transactions of Leningrad Mining Institute]. 116: 78- 81. (Text in Russian.)

Zhigalev, S. P., and A. M. Skurko. 1988. Razrabotka shnekovikh kolonkovikh snaryadov dlya burenia snozhno-firnovikh otlozhenyi Antarktidy (Core augers for drilling in Antarctic snow-firn zones). Zapiski Leningradskogo Gornogo Instituta (Transactions of Leningrad Mining Institute), 116: 64-68. (Text in Russian.)

Zotikov, I. A. 1979. Anti-freeze thermal drilling for core through the central part of the Ross Ice Shelf (J9-Camp), Antarctica. USA Cold Regions research and Engineering Laboratory, CRREL Report 79-24.

Zotikov, I. A., A. P. Kapista, Ye. V. Kudryavtsev, L. A. Sukhanov. 1974. Thermal drilling of the glacier. USA Cold Regions research and Engineering Laboratory, CRREL Draft Translation TL-414. [Termoburenie v lednikakh. Antarktika. Doklady Komissii (The Antarctic. The Committee Reports). Vol. 11, p. 141-156. Text in Russian]. 
Zotikov, I. A., A. P. Kapitsa, and O. G. Sorokhtin. 1965. Teplovoy rezhim lednikovogo pokrova Tsentral'noy Antarktidy (Thermal regime of an Ice Sheet in Central Antarctica). Informatsionny Byulleten' Sovetkoj Antarkticheskoj ekspeditsii (Soviet Antarctic Expedition Information Bulletin), 51: 27- 32. (Text in Russian.)

Zotikov, I. A., V. S. Zagorodnov, Yu. V. Raikovsky, and V. A. Morev. 1981. Kernovoe burenie na shel'fovom lednike Rossa (Core drilling on the Ross Ice Shelf). Informatsionny Byulleten' Sovetkoj Antarkticheskoj Ekspeditsii (Soviet Antarctic Expedition Information Bulletin), 102: 68- 74. (Text in Russian.)

Zotikov, I. A., and N. G. Razumeiko. 1966. Raspredelenie temperatur v lednikokh kupolakh Zemli Frantsa-Iosifa kak otrazhenie kolebanii klimata [Temperature distribution in ice caps of Franz-Josef Land as reflection of climate changes]. Akademiya nauk SSSR. Institut geografii. Materialy gliatsiologicheskikh issledovanii [Academy of Sciences of the USSR. Institute of Geography. Data of Glaciological Studies]. Vol. 12, p. 274-276. (Text in Russian). 


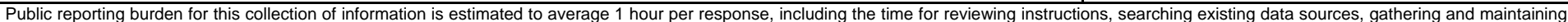

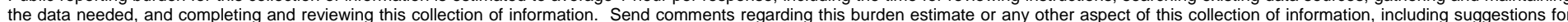

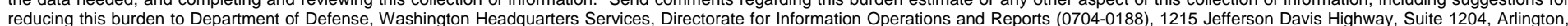

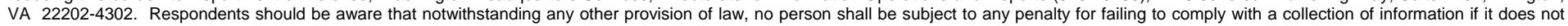
display a currently valid OMB control number. PLEASE DO NOT RETURN YOUR FORM TO THE ABOVE ADDRESS.

\begin{tabular}{l|l}
\hline 1. REPORT DATE (DD-MM-YYYY) & $\begin{array}{l}\text { 2. REPORT TYPE } \\
\text { October } 2007\end{array}$ \\
Technical Report
\end{tabular}

\section{TITLE AND SUBTITLE}

Technical Report

Fifty Years of Soviet and Russian Drilling Activity in Polar and Non-Polar Ice:

A Chronological History

\section{AUTHOR(S)}

Herbert T. Ueda and Pavel G. Talalay

\section{DATES COVERED (From - To)}

5a. CONTRACT NUMBER

5b. GRANT NUMBER

5c. PROGRAM ELEMENT NUMBER

\section{5d. PROJECT NUMBER}

5e. TASK NUMBER

5f. WORK UNIT NUMBER

8. PERFORMING ORGANIZATION REPORT NUMBER

ERDC/CRREL TR-07-20

U.S. Army Engineer Research and Development Center

Cold Regions Research and Engineering Laboratory

72 Lyme Road

Hanover, NH 03755-1290

9. SPONSORING I MONITORING AGENCY NAME(S) AND ADDRESS(ES)
10. SPONSOR/MONITOR'S ACRONYM(S)

11. SPONSOR/MONITOR'S REPORT NUMBER(S)

\section{DISTRIBUTION I AVAILABILITY STATEMENT}

Approved for public release; distribution is unlimited.

Available from NTIS, Springfield, Virginia 22161.

\section{SUPPLEMENTARY NOTES}

\section{ABSTRACT}

Soviet and Russian drilling activity in ice began in 1955 while conducting temperature surveys on a glacier in Franz-Josef Land in the Arctic and continued to 1960 on the glaciers of the polar Ural and the northern Tien Shen mountain ranges. In 1956 the first Complex Antarctic Expedition (CAE) was formed and the first Antarctic drilling was conducted in October of 1956 near Mirny Station. Later, the expeditions were referred to as Soviet Antarctic Expeditions (SAE) and Russian Antarctic Expeditions (RAE). Early efforts were conducted with hand drilling equipment followed by mechanical rotary and percussion drilling techniques. Thermal (flame and thermal electric) boring drills and later thermal coring drills eventually culminated in drills of the TELGA type for thermal drilling deep, dry holes. One such hole reached a depth of over $900 \mathrm{~m}$ at Vostok. Use of TBZS type thermal drills for drilling in fluid-filled holes were also developed, as was a technique using anti-freeze to dissolve the melt water formed, the dilute solution then remaining in the hole to provide the necessary hydrostatic balance. An electro-mechanical drill KEMS was first introduced on Vavilov Glacier, Severnaya Zemlya (Russian Arctic) in 1984 and then in 1989 at Vostok Station. Five major holes have been drilled at Vostok, the last one stopped in 2006 (RAE 51) at a depth of 3650 m, 100 m above Lake Vostok. This report chronologically summarizes the Soviet and Russian efforts over the last 50 years.

\begin{tabular}{|ll}
\hline 15. SUBJECT TERMS & Ice drilling \\
Drilling & Soviet polar research \\
Glaciers & Russian polar research \\
\hline
\end{tabular}

16. SECURITY CLASSIFICATION OF:

a. REPORT

$\mathrm{U}$ c. THIS PAGE

$\mathrm{U}$
17. LIMITATION OF ABSTRACT

$\mathrm{U}$
18. NUMBER OF PAGES

145 19a. NAME OF RESPONSIBLE PERSON

19b. TELEPHONE NUMBER (include area code) 